\title{
Geomorphic Response of the North Fork Stillaguamish River to the State Route 530 Landslide near Oso, Washington
}

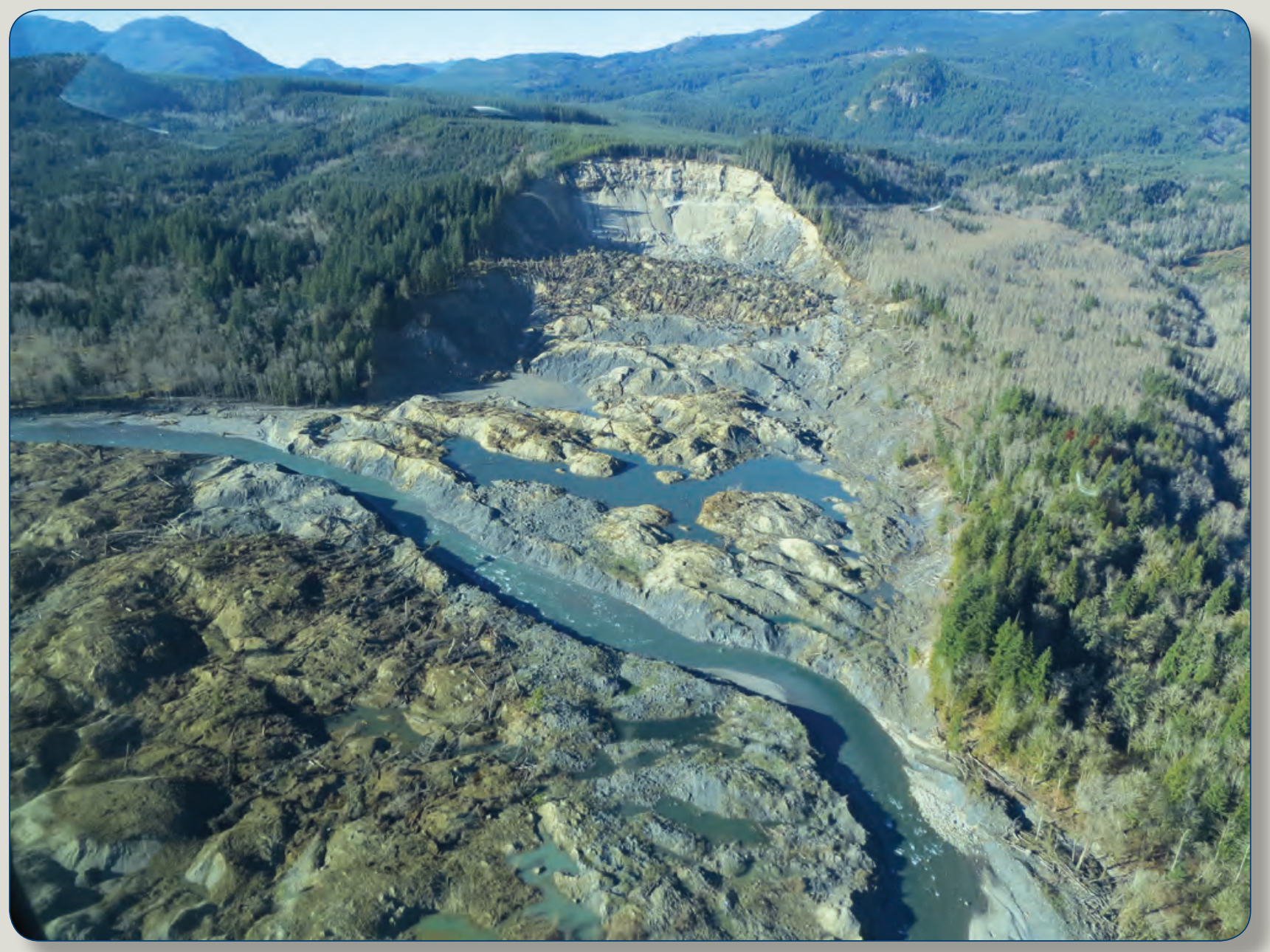

Scientific Investigations Report 2017-5055 
Cover: Photograph showing North Fork Stillaguamish River and SR530 Landslide near Oso Washington; flow is from right to left. Photograph by Scott W. Anderson, U.S.

Geological Survey, Janury 29, 2015. 


\section{Geomorphic Response of the North Fork Stillaguamish River to the State Route 530 Landslide near Oso, Washington}

By Scott W. Anderson, Mackenzie K. Keith, Christopher S. Magirl, J. Rose Wallick, Mark C. Mastin, and James R. Foreman

Prepared in cooperation with the Federal Emergency Management Administration and Snohomish County, Washington

Scientific Investigations Report 2017-5055 


\title{
U.S. Department of the Interior \\ RYAN K. ZINKE, Secretary
}

\section{U.S. Geological Survey William H. Werkheiser, Acting Director}

\author{
U.S. Geological Survey, Reston, Virginia: 2017
}

For more information on the USGS - the Federal source for science about the Earth, its natural and living resources, natural hazards, and the environment-visit https://www.usgs.gov or call 1-888-ASK-USGS.

For an overview of USGS information products, including maps, imagery, and publications, visit https://store.usgs.gov.

Any use of trade, firm, or product names is for descriptive purposes only and does not imply endorsement by the U.S. Government.

Although this information product, for the most part, is in the public domain, it also may contain copyrighted materials as noted in the text. Permission to reproduce copyrighted items must be secured from the copyright owner.

Suggested citation:

Anderson, S.W., Keith, M.K., Magirl, C.S., Wallick, J.R., Mastin, M.C., and Foreman, J.R., 2017, Geomorphic response of the North Fork Stillaguamish River to the State Route 530 landslide near Oso, Washington: U.S. Geological Survey Scientific Investigations Report 2017-5055, 85 p., https://doi.org/10.3133/sir20175055.

ISSN 2328-0328 (online) 


\section{Contents}

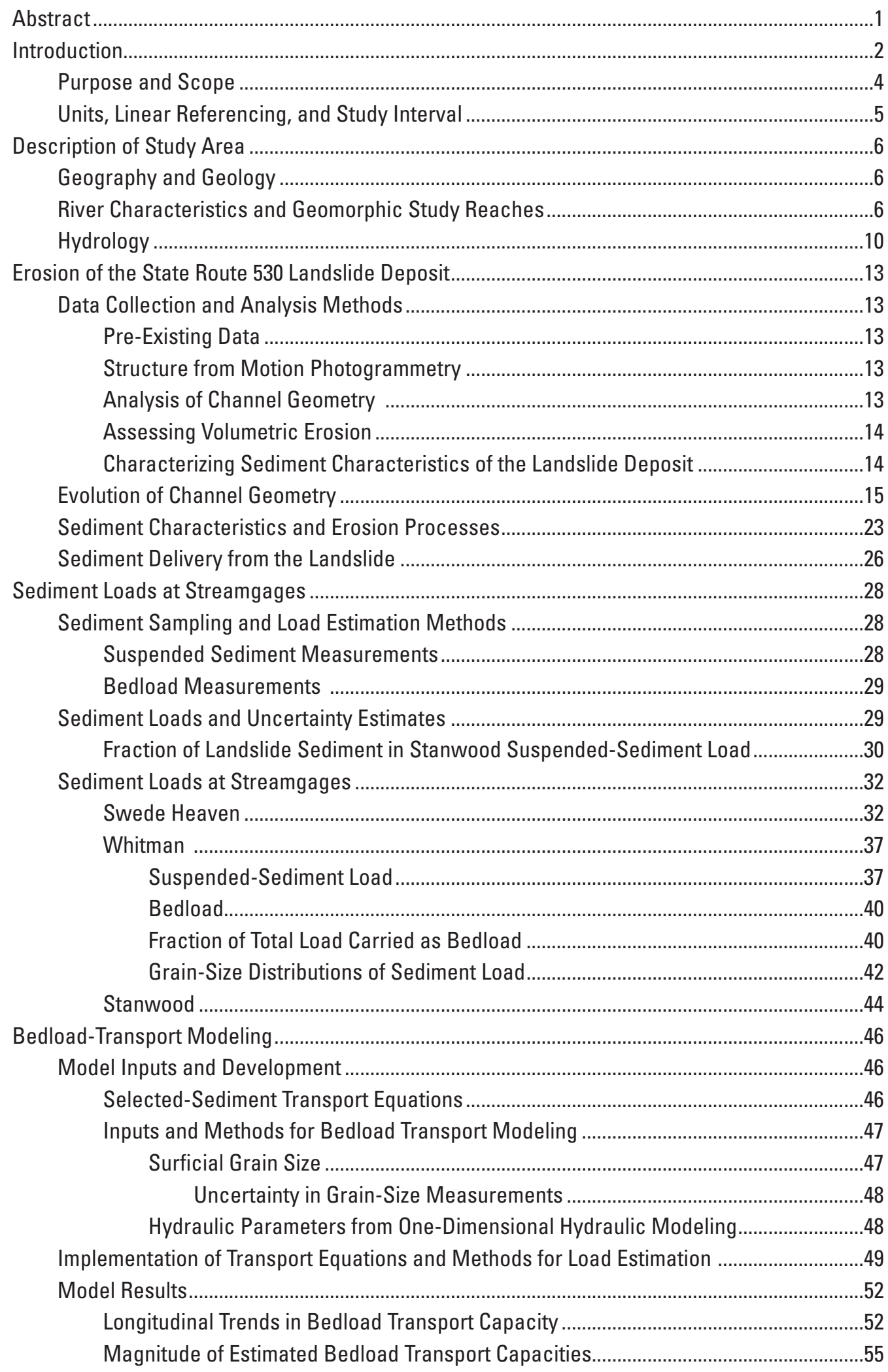




\section{Contents-Continued}

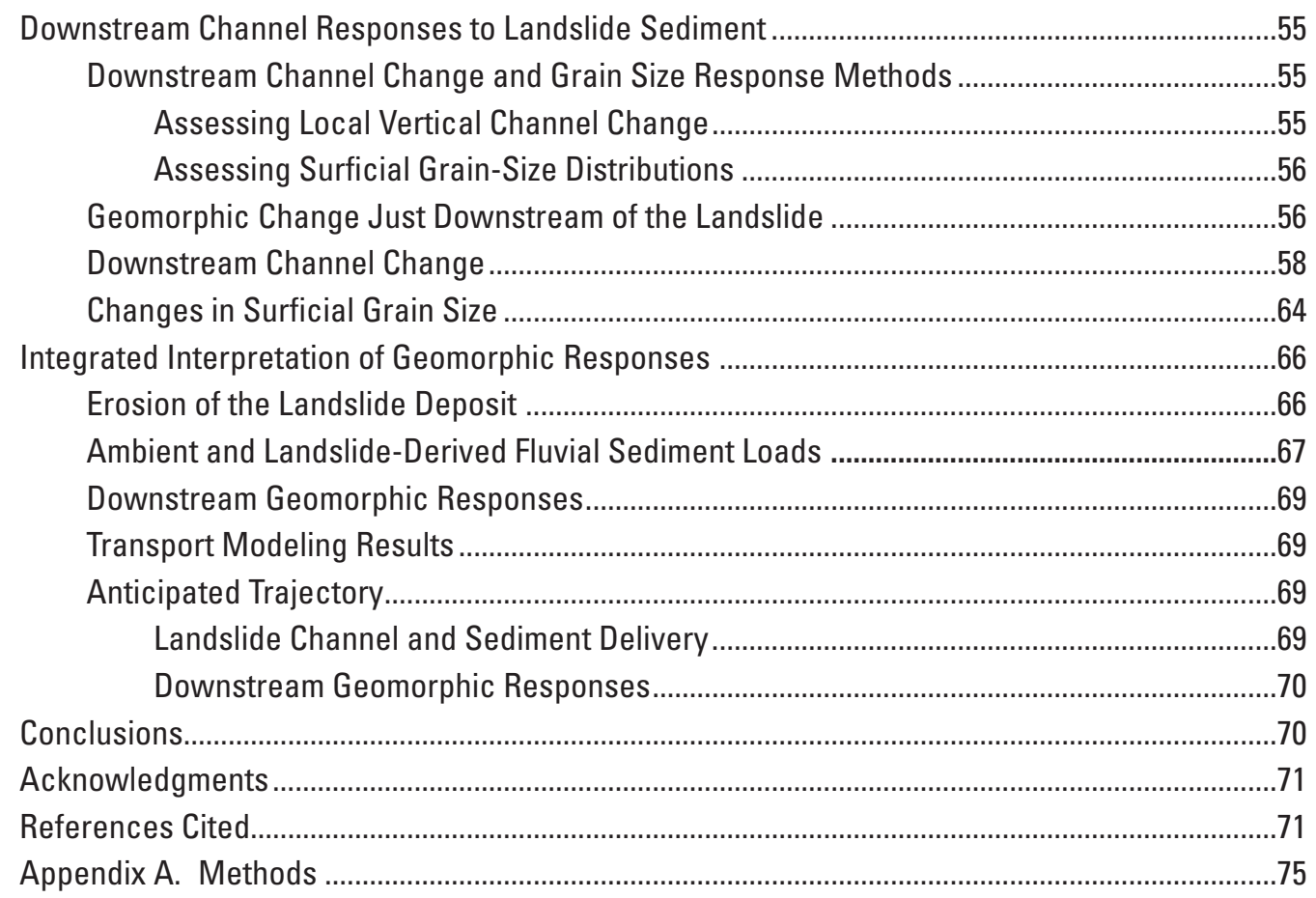

\section{Figures}

1. Map showing State Route 530 Landslide extent and selected U.S. Geological Survey streamgages in the North Fork Stillaguamish River Basin, Washington

2. Map showing State Route 530 Landslide and maximum impoundment extents in the North Fork Stillaguamish River Valley, Washington

3. Maps and cross section showing topography of the State Route 530 Landslide prior to and immediately after the March 22, 2014, landslide, and cross section through the center of the slide deposit in the cross-valley direction, North Fork Stillaguamish River, Washington

4. Map showing study reaches, streamgages, and grain-size measurement sites on the North Fork Stillaguamish River, Washington.

5. Photographs showing typical channel conditions in the four primary study reaches along the North Fork Stillaguamish River, Washington.

6. Graphs showing discharge in 15-minute increments for streamgages North Fork Stillaguamish River near Arlington and North Fork Stillaguamish River near Oso, Washington, March 2014-September 2015.

7. Graph showing annual instantaneous peak discharges at streamgage North Fork Stillaguamish near Arlington, Washington, for period of record and study period.........12

8. Graph showing monthly mean discharge at North Fork Stillaguamish River at Arlington, Washington, March 2014-September 2015

9. Oblique aerial photographs showing re-establishment of a channel through the SR 530 Landslide deposit along the North Fork Stillaguamish River near Oso, Washington. 


\section{Figures-Continued}

10. Repeat orthoimages showing evolution of the new channel through the landslide deposit along the North Fork Stillaguamish River near Oso, Washington...

11. Longitudinal profiles of water-surface elevation through the landslide reach and the immediate downstream reach along the North Fork Stillaguamish River,

Washington.

12. Graphs showing changes in mean water-surface elevation and mean channel width through the landslide deposit along the North Fork Stillaguamish River, Washington, March 2014-July 2015.

13. Repeat cross-section profiles of the newly eroded channel of the North Fork Stillaguamish River, Washington.

14. Photographs showing new channel through the landslide deposit along the North Fork Stillaguamish River, Washington, September 9, 2014, and January 29, 2015.

15. Digital elevation model images showing vertical change in SR 530 Landslide deposit based on topographic differencing, North Fork Stillaguamish River, Washington

16. Map showing surficial sample sites and generalized facies units determined from field and remote sources, SR 530 Landslide area, North Fork Stillaguamish River, Washington, autumn and winter 2014-15

17. Photographs showing typical bank conditions through the landslide deposit along North Fork Stillaguamish River, Washington, water year 2015.

18. Graph showing grain-size distributions of landslide deposit facies from the SR 530 Landslide, North Fork Stillaguamish River, Washington .

19. Graph showing cumulative mass of erosion and grain-size classes from the SR 530 Landslide deposit, North Fork Stillaguamish River, Washington.

20. Graphs showing cumulative erosion and erosion efficiency of the SR 530 Landslide deposit over time, North Fork Stillaguamish River, Washington.

21. Photographs showing bedload sampling using an Elwha bedload sampler and a TR-2 bedload sampler at Whitman Road bridge, North Fork Stillaguamish River near Oso, Washington.

22. Graphs showing discharge and turbidity at the mouth of the main-stem Stillaguamish River near Stanwood Washington, November 2013-September 2015.....31

23. Graph showing daily suspended-sediment load and daily mean discharge at Stillaguamish River near Stanwood, Washington

24. Graph showing turbidity, discharge and suspended-sediment concentrations at North Fork Stillaguamish near Swede Heaven, Washington..

25. Graphs showing regressions between turbidity and suspended-sediment concentration and suspended-sediment finer than 0.063 millimeter at North Fork Stillaguamish near Swede Heaven, Washington

26. Graphs showing cumulative sediment transport at Swede Heaven, upstream of the landslide, and Whitman, downstream of the landslide, North Fork Stillaguamish River near Oso, Washington

27. Graph showing turbidity, discharge, and suspended-sediment concentrations at North Fork Stillaguamish near 0so, Washington

28. Graphs showing regressions between turbidity and measured suspended-sediment concentrations and suspended sediment finer than 0.063 millimeters at North Fork Stillaguamish near Oso, Washington. 


\section{Figures-Continued}

29. Graph showing measured bedload transport rates in relation to discharge at North Fork Stillaguamish River near Oso), Washington), water years 2014 and 2015.

30. Graphs showing grain-size distributions from bedload measurements made at Whitman Road Bridge, North Fork Stillaguamish River near Oso, Washington ..............43

31. Graph showing percentage of the fluvial sediment load in a given grain size class and transport mode at Whitman Road Bridge, North Fork Stillaguamish River near Oso, Washington.

32. Graph showing cumulative suspended-sediment loads estimated using the turbidity-suspended-sediment concentration relation and the dischargesuspended-sediment load regression for the pre-landslide period at Stillaguamish River near Stanwood, Washington.

33. Longitudinal profile of water-surface elevation based on aerial lidar, and surficial grain-size characteristics from measurements made at the North Fork Stillaguamish River, Washington, summer 2014

34. Graphs showing grain-size distributions used in sediment-transport modeling at selected reaches, North Fork Stillaguamish River, Washington, water year 2014

35. Graphs showing sediment transport calculations from wetted width, in-channel hydraulic radius, and energy slope from one-dimensional hydraulic models, North Fork Stillaguamish River near Oso, Washington

36. Graphs showing calculated transport capacities for a range of moderate to high flows for four transport equations along the North Fork Stillaguamish River, Washington

37. Graphs showing cumulative bedload transport capacity during the study period along the North Fork Stillaguamish River, Washington, during March 22, 2014September 30, 2015.

38. Aerial photographs and light detection and ranging (lidar) images showing planform and vertical change just downstream of the SR 530 Landslide, North Fork Stillaguamish River near 0so, Washington.

39. Graphs showing streamgage analysis of relative change in stage for a fixed discharge, mean elevation of cross sections, and cross-section profiles of the North Fork Stillaguamish River at Rowan, Washington..

40. Graphs showing streamgage analysis of relative change in stage for a fixed discharge, mean elevation of cross sections at site subset of available cross-section profiles at North Fork Stillaguamish River near 0so, Washington

41. Graphs showing streamgage analysis of relative change in stage for a fixed discharge at North Fork Stillaguamish River at Whitehorse Trail near Oso North Fork Stillaguamish River at Oso; mean elevation of cross sections; and cross-section profiles at 221 st Avenue streamgage, Washington.

42. Repeat orthoimages showing change between river kilometers 24 and 25.5 at the North Fork Stillaguamish River, Washington, between September 2013 and September 2015

43. Repeat orthoimages showing change between river kilometers 28.5 and 30.5 at the North Fork Stillaguamish River, Washington, between September 2013 and September 2015.

44. Graphs showing surface particle counts and median gravel-particle sizes upstream and downstream of the SR 530 Landslide, North Fork Stillaguamish River, Washington 


\section{Figures-Continued}

45. Graphs showing surficial particle-size distributions for co-located sample sites in selected reaches along the North Fork Stillaguamish River, Washington

46. Graph showing grain-size distribution of sediment eroded from the landslide and full grain-size distribution of the fluvial sediment load at Whitman Road Bridge,

North Fork Stillaguamish River, Washington.

47. Graph showing cumulative eroded landslide mass based on repeat topography compared against estimated landslide sediment in suspended-sediment load at North Fork Stillaguamish River near Stanwood, Washington.

\section{Tables}

1. Datasets, acquisition information, coverage, resolution, and data sources used for analysis, North Fork Stillaguamish River near Oso, Washington

2. Locations of sites used to assess geomorphic response of the North Fork Stillaguamish River to the State Route 530 Landslide near Oso, Washington ...

3. Reach characteristics along the North Fork Stillaguamish River, Washington.

4. U.S. Geological Survey streamgages along the North Fork Stillaguamish River, Washington.

5. Differences in water-surface elevation, relative to January 29, 2015 conditions, at selected streamgages near the SR 530 Landslide, North Fork Stillaguamish River, Washington.

6. Generalized geologic units, descriptions, and grain-size characteristics from field and laboratory analyses of deposit material of the SR 530 Landslide along the North Fork Stillaguamish River, Washington.

7. Erosion of the SR 530 Landslide deposit measured through repeat topographic surveys, North Fork Stillaguamish River, Washington.

8. Suspended-sediment concentrations at North Fork Stillaguamish River near Swede Heaven, Washington (USGS streamgage 12166185).

9. Estimated sediment loads at selected streamgage sites, North Fork Stillaguamish River, Washington.

10. Suspended-sediment samples collected at Whitman Road Bridge, North Fork Stillaguamish River, Washington (USGS streamgage 12166300).

11. Bedload samples collected at Whitman Road Bridge, North Fork Stillaguamish River, Washington (USGS streamgage 12166300)

12. Ratios of bedload to total load based on paired measurements of suspended-sediment and bedload transport rates at Whitman Road Bridge, North Fork Stillaguamish River, Washington (USGS streamgage 12166300)

13. Mass of landslide erosion and estimated landslide material at North Fork Stillaguamish River near Stanwood, Washington (USGS streamgage 12170300)

14. Annual exceedance probability flow scenarios and discharges for the North Fork Stillaguamish River near Arlington, Washington (USGS streamgage 12167000).

15. Estimated reach-median bedload transport capacity after the SR 530 Landslide along the North Fork Stillaguamish River, Washington. 


\section{Conversion Factors}

International System of Units to U.S. customary units

\begin{tabular}{|c|c|c|}
\hline Multiply & By & To obtain \\
\hline \multicolumn{3}{|c|}{ Length } \\
\hline centimeter (cm) & 0.3937 & inch (in.) \\
\hline millimeter (mm) & 0.03937 & inch (in.) \\
\hline meter $(\mathrm{m})$ & 3.281 & foot (ft) \\
\hline kilometer (km) & 0.6214 & mile (mi) \\
\hline \multicolumn{3}{|c|}{ Area } \\
\hline square kilometer $\left(\mathrm{km}^{2}\right)$ & 247.1 & acre \\
\hline square meter $\left(\mathrm{m}^{2}\right)$ & 10.76 & square foot $\left(\mathrm{ft}^{2}\right)$ \\
\hline \multicolumn{3}{|c|}{ Volume } \\
\hline cubic meter $\left(\mathrm{m}^{3}\right)$ & 1.308 & cubic yard $\left(\mathrm{yd}^{3}\right)$ \\
\hline \multicolumn{3}{|c|}{ Flow rate } \\
\hline meter per second (m/s) & 3.281 & foot per second (ft/s) \\
\hline cubic meter per second $\left(\mathrm{m}^{3} / \mathrm{s}\right)$ & 35.31 & cubic foot per second $\left(\mathrm{ft}^{3} / \mathrm{s}\right)$ \\
\hline cubic meter per year $\left(\mathrm{m}^{3} / \mathrm{yr}\right)$ & 0.000811 & acre-foot per year (acre-ft/yr) \\
\hline \multicolumn{3}{|c|}{ Velocity } \\
\hline kilometer per hour (km/h) & 0.6214 & mile per hour (mi/h) \\
\hline \multicolumn{3}{|c|}{ Mass } \\
\hline kilogram (kg) & 2.205 & pound avoirdupois (lb) \\
\hline megagram (Mg) & 1.102 & ton, short $(2,000 \mathrm{lb})$ \\
\hline metric ton per day & 1.102 & ton per day (ton/d) \\
\hline megagram per day (Mg/d) & 1.102 & ton per day (ton/d) \\
\hline $\begin{array}{l}\text { megagram per day per square } \\
\text { kilometer }\left[(\mathrm{Mg} / \mathrm{d}) / \mathrm{km}^{2}\right]\end{array}$ & 2.8547 & $\begin{array}{l}\text { ton per day per square mile } \\
{\left[(\operatorname{ton} / \mathrm{d}) / \mathrm{mi}^{2}\right]}\end{array}$ \\
\hline megagram per year (Mg/yr) & 1.102 & ton per year (ton/yr) \\
\hline metric ton per year & 1.102 & ton per year (ton/yr) \\
\hline $\begin{array}{l}\text { kilograms per meter per second } \\
{[(\mathrm{kg} / \mathrm{m}) / \mathrm{s}]}\end{array}$ & 0.672 & $\begin{array}{l}\text { pounds per foot per second } \\
{[(\mathrm{lb} / \mathrm{ft}) / \mathrm{s}]}\end{array}$ \\
\hline kilogram per second (kg/s) & 2.205 & pounds per second \\
\hline \multicolumn{3}{|c|}{ Density } \\
\hline kilogram per cubic meter $\left(\mathrm{kg} / \mathrm{m}^{3}\right)$ & 0.06242 & pound per cubic foot $\left(\mathrm{lb} / \mathrm{ft}^{3}\right)$ \\
\hline
\end{tabular}

Temperature in degrees Celsius $\left({ }^{\circ} \mathrm{C}\right)$ may be converted to degrees Fahrenheit $\left({ }^{\circ} \mathrm{F}\right)$ as:

$$
{ }^{\circ} \mathrm{F}=\left(1.8 \times{ }^{\circ} \mathrm{C}\right)+32 .
$$

\section{Datums}

Vertical coordinate information is referenced to the North American Vertical Datum of 1988 (NAVD 88).

Horizontal coordinate information is referenced to the North American Datum of 1983 (NAD 83).

Altitude, as used in this report, refers to distance above the vertical datum. 


\section{Supplemental Information}

Concentrations of chemical constituents in water are given in either milligrams per liter (mg/L) or micrograms per liter ( $\mu \mathrm{g} / \mathrm{L})$.

\section{Abbreviations}

$\begin{array}{ll}\text { AEP } & \text { annual exceedance probability } \\ \text { BAGS } & \text { Bedload Assessment in Gravel-bedded Streams } \\ \text { DEM } & \text { digital elevation model } \\ \text { EC } & \text { Environment Canada } \\ \text { EPA } & \text { U.S. Environmental Protection Agency } \\ \text { EDI } & \text { equal-discharge-increment method of sampling } \\ \text { EWI } & \text { equal-width-increment method of sampling } \\ \text { GNSS } & \text { Global Navigation Satellite System } \\ \text { HEC-RAS } & \text { Hydraulic Engineering Center-River Analysis System } \\ \text { NAIP } & \text { National Agriculture Imagery Program } \\ \text { NWIS } & \text { National Water Information System } \\ \text { rkm } & \text { river kilometer } \\ \text { RTK } & \text { real time kinematic } \\ \text { SfM } & \text { Structure-from-Motion photogrammetry } \\ \text { SSC } & \text { suspended-sediment concentration } \\ \text { SSL } & \text { suspended-sediment load } \\ \text { USGS } & \text { U.S. Geological Survey } \\ \text { WSDOT } & \text { Washington State Department of Transportation } \\ \text { WY } & \text { water year (starts on October 1 and ends September 30 the following year) }\end{array}$





\title{
Geomorphic Response of the North Fork Stillaguamish River to the State Route $\mathbf{5 3 0}$ Landslide near Oso, Washington
}

\author{
By Scott W. Anderson, Mackenzie K. Keith, Christopher S. Magirl, J. Rose Wallick, Mark C. Mastin, and \\ James R. Foreman
}

\section{Abstract}

On March 22, 2014, the State Route 530 Landslide near Oso, Washington mobilized 8 million cubic meters of unconsolidated Pleistocene material, creating a valley-spanning deposit that fully impounded the North Fork Stillaguamish River. The river overtopped the 8-meter high debris impoundment within 25 hours and began steadily incising a new channel through the center of the deposit. Repeat topographic surveys, sediment transport measurements, bedload transport models, and observations of downstream channel change were used to document the establishment of that new channel through the landslide and assess the potential for downstream aggradation or channel change that might increase downstream flood hazards.

Efficient erosion of the landslide deposit, associated with the steep knickzone formed by the downstream edge of the deposit, resulted in the re-establishment of a 20-40 meters wide, deeply inset channel through the entire deposit by May 2014, 2 months after the landslide. The mean watersurface elevation of the channel through the landslide decreased 7 meters during that 2-month period, and was about 1 meter above the pre-landslide profile in July 2014. The 2014-15 flood season, which included flows near the 0.5 annual exceedance probability discharge (2-year flood), widened the channel tens of meters, and further lowered the water-surface profile 0.5 meter. The planform position evolved slowly as a result of 5-20-meter high banks predominantly composed of clay-rich, cohesive lacustrine material. Erosion of the landslide deposit delivered a total of 820 thousand metric tons of sediment to the North Fork Stillaguamish River over the 18 months following the landslide. The sediment delivery from the deposit was predominantly fine grained: 77 percent (by mass) of the eroded material was silt or clay (less than 0.063 millimeter [mm]), 19 percent sand (0.063-2 mm), and 4 percent pebbles and cobbles (greater than $2 \mathrm{~mm}$ ).

Over the 18 months following the landslide, the bedload at a site 5 kilometers downstream of the landslide was estimated to be $310 \pm 65$ thousand metric tons, and the suspended load at that same site was estimated to be $990 \pm 110$ thousand metric tons. These loads represent the combined input from the landslide and ambient upstream sources; over the study interval, landslide sediment made up about 20-40 percent of the bedload, and 65-85 percent of the suspended-sediment load at this site. At a site 70 kilometers downstream of the landslide, near the mouth of the main-stem Stillaguamish River, suspended sediment loads were estimated to be about 1,440 thousand metric tons, of which about 600 thousand metric tons, or 30 percent, likely was derived from the landslide. The mass of landslide sediment in suspension at the mouth of the river, and the timing of arrival of that sediment, indicates that about 70 percent of the landslide sediment eroded during the study period was quickly transported through the entire basin, exiting into Puget Sound within weeks of initial entrainment.

Empirical bedload transport equations, in conjunction with surficial grain-size data and output from a one-dimensional hydraulic model, were used to estimate spatial trends in bedload transport capacity, highlighting areas where reach-scale conditions would be most likely to promote deposition of coarse landslide sediment. Transport capacities decreased sharply over a reach about 5 kilometers downstream of the landslide and remained relatively low over the next 10 kilometers downstream. However, the magnitude of calculated transport capacities are large relative to the coarse sediment input from the landslide, suggesting that substantial deposition of landslide sediment was not likely to occur. These assessments were corroborated by observations of channel change, which indicated that the downstream channel response to the landslide was modest and short-lived. The most pronounced downstream effects included a wedge of aggradation just downstream of the landslide, about 1 meter high and extending a kilometer downstream, and a 0.3-meter pulse of aggradation observed 5 kilometers downstream of the landslide. In both locations, peak aggradation and channel response occurred within about a month of the landslide, and both sites had largely recovered to pre-landslide conditions by July 2014. No substantial channel change clearly linked to the landslide was observed after July 2014 except for 
a modest fining of surficial gravel size distributions and continued recovery and incision of the reach just downstream of the landslide.

The muted downstream response of the North Fork Stillaguamish River to the State Route 530 Landslide primarily can be attributed to the cohesive, silt- and clay-rich material that bounded most of the new channel. Although the river efficiently incised a new channel through the deposit, subsequent rates of lateral erosion were slowed by the tall, cohesive banks, limiting the total volume of sediment delivery. Once entrained, however, most landslide material was rapidly transported downstream in suspension with little geomorphic effect. Landslide material coarse enough to travel as bedload was predominantly sand and fine gravel, and sediment transport models and observations of downstream change indicated that the rate of coarse sediment delivery from the landslide did not exceed the rivers ability to transport that material. The generally muted downstream response to sediment delivery from the State Route 530 Landslide, as well as the mechanics of that delivery and response, were generally consistent with observations made following the intentional removal of constructed dams.
The rate and efficiency of erosion from the landslide decreased over the period of analysis, as the new channel approached a quasi-equilibrium form. In the absence of additional hillslope activity, rates of erosion from the landslide are likely to be small compared to those over the first 18 months after the landslide. The modest channel response to the highest rates of sediment delivery, and rapid recovery thereafter, indicate that the river should be able to convey the continued supply of landslide-derived sediment effectively with little effect on the downstream morphology and flood risks.

\section{Introduction}

On March 22, 2014, an 8 million cubic meter $\left(\mathrm{m}^{3}\right)$ landslide (Iverson and others, 2015) fully traversed the flood plain of the North Fork Stillaguamish River east of Oso, Washington, covering 1.4 square kilometers $\left(\mathrm{km}^{2}\right)$ of the valley floor (figs. 1-3) (Keaton, and others, 2014; Iverson and others, 2015; Magirl, Keith, and others 2015; Wartman

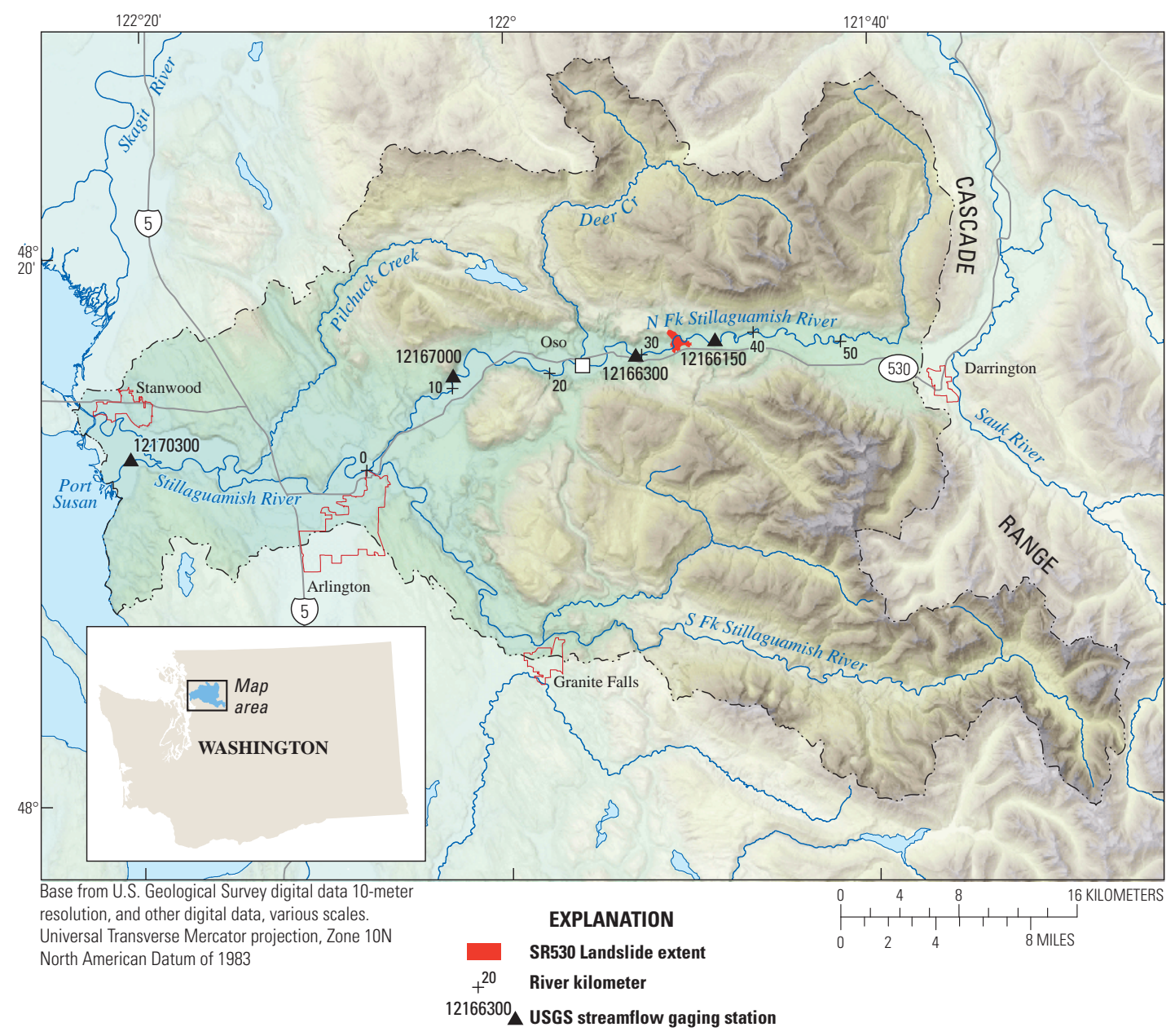

Figure 1. State Route 530 Landslide (SR 530 Landslide) extent and selected U.S. Geological Survey streamgages in the North Fork Stillaguamish River Basin, Washington. 
and others, 2016). Officially named the State Route 530 Landslide (herein SR 530 Landslide or simply landslide), the mass movement resulted in 43 fatalities, making it one of the deadliest landslides in United States history. The landslide originated from a 190-meter (m) tall bluff composed of late Pleistocene outwash gravel, glacial till, and lacustrine units (Magirl, Keith, and others, 2015; Riemer and others, 2015; Wartman and others, 2016). The hummocky landslide deposit temporarily dammed the North Fork Stillaguamish River, forming an 8-m-deep impoundment lake that covered $1.5 \mathrm{~km}^{2}$ and extended $3 \mathrm{~km}$ upstream (fig. 2; Magirl, Keith, and others, 2015). After 25 hours, the river overtopped the landslide deposit near the northern extent of the pre-landslide flood plain. The river then began incising a channel through the center of the landslide deposit, delivering sediment to downstream reaches. If the increased sediment load exceeded the rivers ability to transport that material, the excess sediment would be deposited on the riverbed and result in aggradation of the bed. Substantial channel bed aggradation can increase both flood stages and lateral channel mobility (Lisle, 2007). The landslide then may pose an indirect hazard to downstream communities through increased sediment loading to the North Fork Stillaguamish River.

Persistent or substantial aggradation in gravel-bedded rivers like the North Fork Stillaguamish River occur primarily in response to the delivery of coarse sands and gravel that make up the bed. Although the delivery of finer sands, silts, and clays may result in temporary deposition and have negative effects on local ecosystems (Wood and Armitage, 1997), this finer material is readily transported in suspension at moderate and high flows and is not likely to affect flood stages. For this reason, the delivery and transport of coarse material is of primary concern. However, observations of the delivery and fate of both fine and coarse sediment is used herein to better understand the downstream geomorphic response as a whole. This work was performed at the request of the Federal Emergency Management Agency and Snohomish County Department of Public Works.

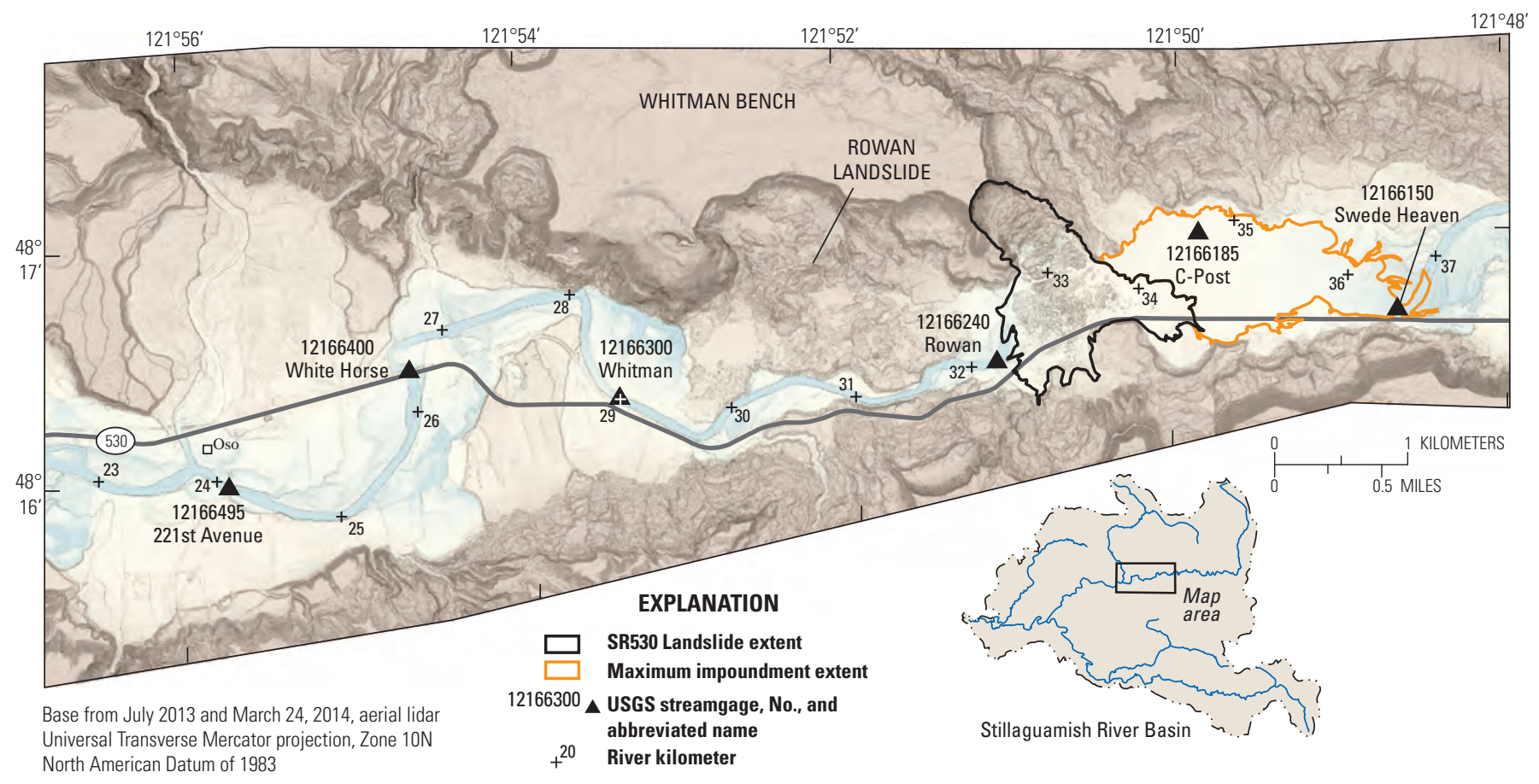

Figure 2. State Route 530 Landslide (SR 530 Landslide) and maximum impoundment extents in the North Fork Stillaguamish River Valley, Washington. 
A. July 2013

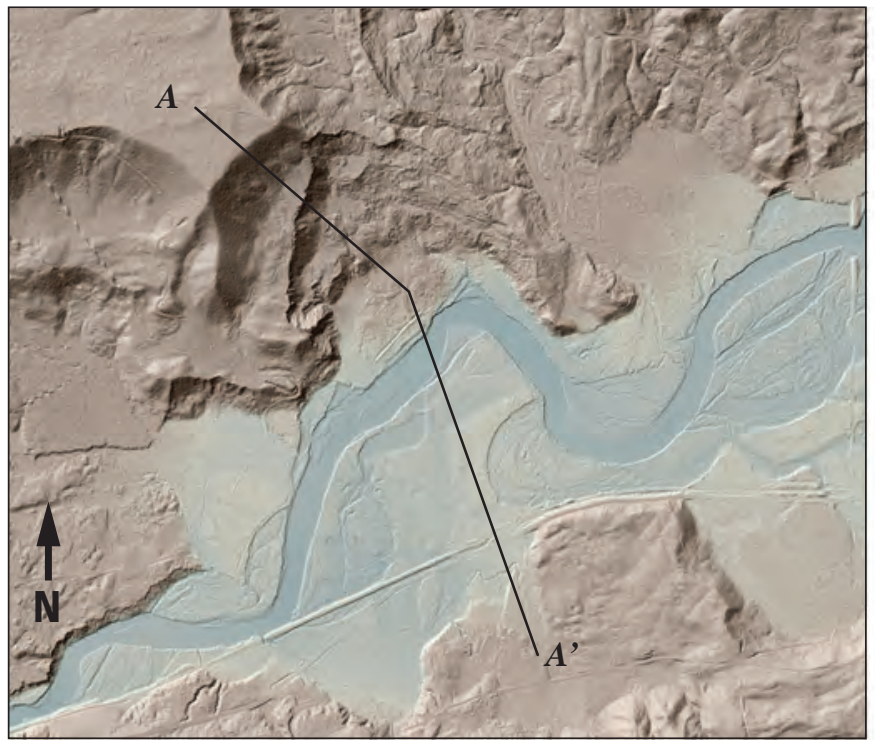

Base from July 2013 and March 24, 2014, aerial lidar Universal Transverse Mercator projection, Zone 10N

North American Datum of 1983

\section{B. March 24, 2014}

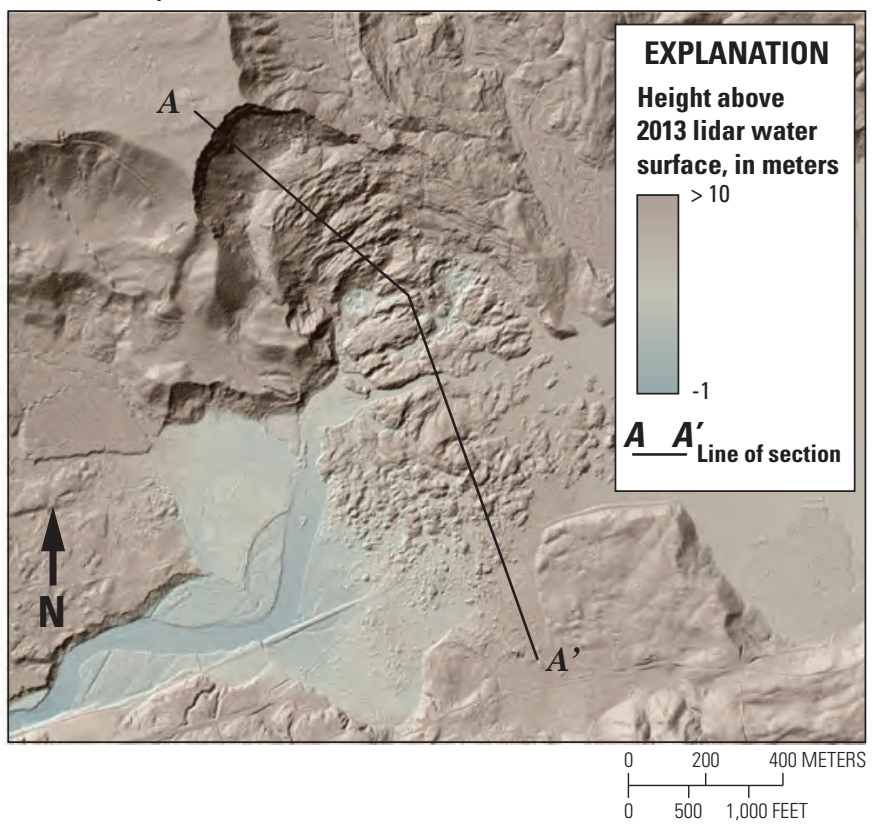

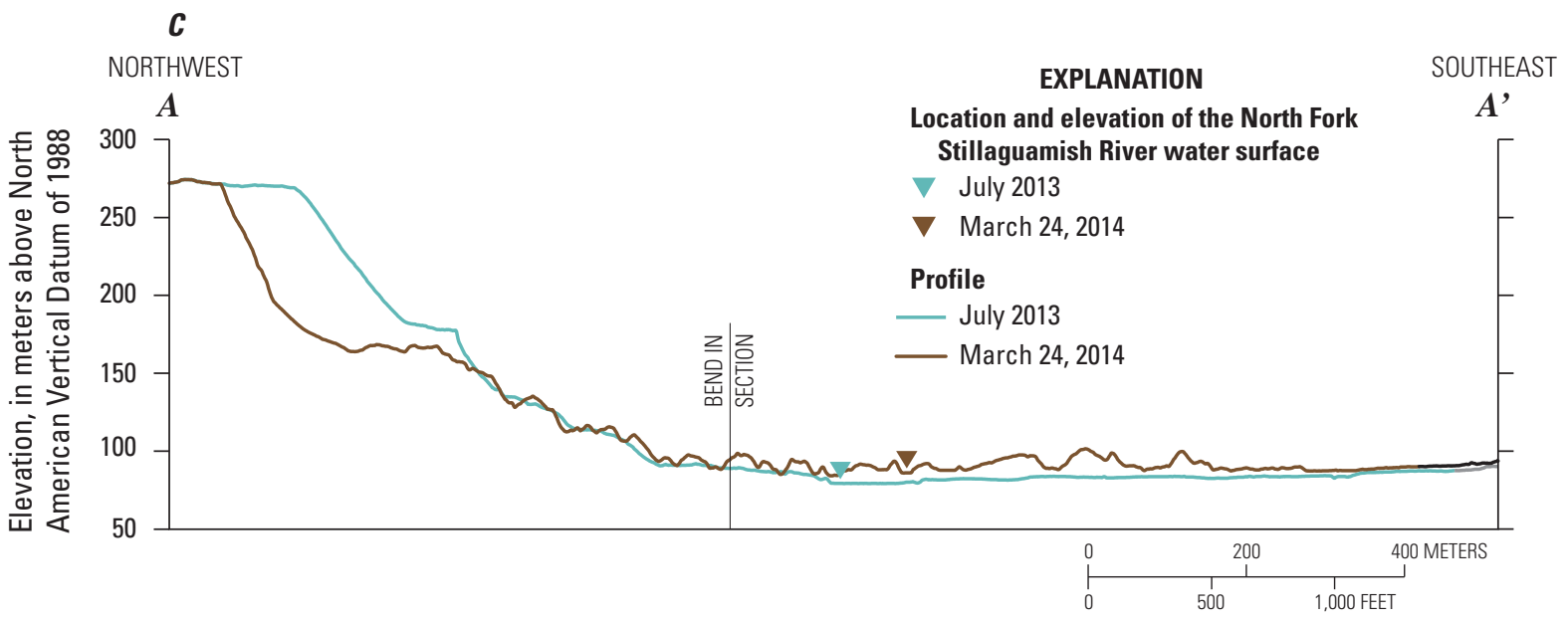

Figure 3. Topography of the State Route 530 Landslide $(A)$ prior to and $(B)$ immediately after the March 22, 2014, landslide, and $(C)$ cross section through the center of the slide deposit in the cross-valley direction, North Fork Stillaguamish River, Washington.

\section{Purpose and Scope}

To assess the recent and anticipated geomorphic response of the North Fork Stillaguamish River to the SR 530 Landslide, the U.S. Geological Survey (USGS) monitored erosion from the landslide, the downstream transport of that eroded sediment, and associated downstream channel change. This observational information was augmented by sedimenttransport modeling results that were further used to assess the potential for future geomorphic responses. This report presents four major elements as part of that study:
1. Repeat topography and aerial imagery of the landslide deposit acquired between March 2014 and July 2015 was used to quantify the evolution of the new channel and volumetric erosion;

2. Continuous hydrologic and water-quality data were collected at several streamgages and paired with discrete measurements of sediment transport in order to estimate fluvial sediment loads over the period of analysis both upstream and downstream of the landslide; 
3. Spatial trends in bedload transport capacity were estimated over $39 \mathrm{~km}$ downstream of the landslide using empirical sediment transport equations to highlight reaches where downstream trends in transport capacity would suggest preferential deposition of landslide sediment; and

4. Field-based and remotely sensed measurements were used to characterize the observed downstream response to the landslide over the study interval.

The purpose of this study is to assess the observed or anticipated rates of channel bed aggradation as a result of the landslide. Although the motivation to assess aggradation is the associated increase in flood hazards, it is outside the scope of this work to assess the actual increase in flood risk that may be associated with a given amount of aggradation in a given location. The work presented herein builds on the earlier observations of Magirl, Keith, and others (2015) who documented the erosion of the landslide deposit through July 2014 and presented early assessments of the potential for downstream geomorphic change in response to the landslide.

\section{Units, Linear Referencing, and Study Interval}

Locations along the North Fork Stillaguamish River in this report are given in river kilometers (rkm) upstream of the confluence with the South Fork Stillaguamish in Arlington, measured along the wetted channel centerline in the 2013 National Agriculture Imagery Program (NAIP) aerial photography (table 1). The location of sites referenced in this study are listed in table 2, including equivalent distances in river miles.

The study period spanned 18 months, from March 22, 2014, the date of the landslide, through September 30, 2015, the end of water year 2015 (WY 2015). Throughout this report, "WY 2014-LS" is used to refer to the period of WY 2014 following the landslide (March 22, 2014September 30, 2014) to distinguish it from the full water year (October 1, 2013-September 30, 2014).

Table 1. Datasets, acquisition information, coverage, resolution, and data sources used for analysis, North Fork Stillaguamish River near Oso, Washington.

[Dataset: Lidar, light detection and ranging. Repository and Source NAIP, National Agriculture Imagery Program; NRCS, Natural Resources Conservation Service; PSLC, Puget Sound Lidar Consortium; USGS, U.S. Geological Survey; WSDOT, Washington State Department of Transportation. Abbreviations m, meter; NA, not applicable; rkm, river kilometer]

\begin{tabular}{|c|c|c|c|c|c|c|}
\hline \multirow{2}{*}{ Dataset } & \multirow{2}{*}{ Date } & \multirow{2}{*}{$\begin{array}{l}\text { Coverage } \\
\text { (rkm) }\end{array}$} & \multicolumn{2}{|c|}{ Resolution (m) } & \multirow{2}{*}{ Repository } & \multirow{2}{*}{ Source } \\
\hline & & & Topographic & Photographic & & \\
\hline \multirow[t]{2}{*}{ Lidar } & 07-01-13 & $46.8-4.5$ & 1 & NA & PSLC & PSLC \\
\hline & 04-06-14 & $43.1-0.0$ & 1 & NA & PSLC & WSDOT \\
\hline \multirow{6}{*}{$\begin{array}{l}\text { Structure from Motion (SfM)- } \\
\text { Topography and aerial } \\
\text { photography }\end{array}$} & ${ }^{1} 07-01-14$ & $34.8-32.0$ & 0.25 & 0.08 & USGS & WSDOT \\
\hline & $12-01-14$ & $34.8-32.0$ & 0.25 & 0.07 & USGS & USGS \\
\hline & 01-06-15 & $34.8-32.0$ & 0.25 & 0.07 & USGS & USGS \\
\hline & 01-29-15 & $34.8-32.0$ & 0.25 & 0.07 & USGS & USGS \\
\hline & 03-18-15 & $34.8-32.0$ & 0.25 & 0.07 & USGS & USGS \\
\hline & $07-07-15$ & $34.8-32.0$ & 0.25 & 0.07 & USGS & USGS \\
\hline & 05-01-14 & $40.4-30.2$ & NA & 0.08 & WSDOT & WSDOT \\
\hline & 07-01-14 & $40.4-30.0$ & NA & 0.08 & WSDOT & WSDOT \\
\hline & 07-07-15 & 35-0 & NA & 0.25 & USGS & USGS \\
\hline & 09-28-15 & Full study area & NA & 1 & NRCS & NAIP \\
\hline
\end{tabular}

${ }^{1} \mathrm{SfM}$ based on aerial photography by WSDOT. 
Table 2. Locations of sites used to assess geomorphic response of the North Fork Stillaguamish River to the State Route 530 Landslide near Oso, Washington.

\begin{tabular}{|c|c|c|c|c|c|}
\hline $\begin{array}{c}\text { River } \\
\text { kilometer }\end{array}$ & Location & $\begin{array}{l}\text { River } \\
\text { mile }\end{array}$ & $\begin{array}{c}\text { River } \\
\text { kilometer }\end{array}$ & Location & $\begin{array}{c}\text { River } \\
\text { mile }\end{array}$ \\
\hline 56.5 & Uspstream end of study area & 34.5 & \multirow[t]{3}{*}{26.3} & Whitehorse Trail railroad bridge at Oso; & \multirow[t]{3}{*}{16.1} \\
\hline 48.8 & Swede Heaven Road bridge & 29.8 & & North Fork Stillaguamish River at & \\
\hline 39.1 & Boulder River & 23.9 & & Whitehorse Trail (streamgage 12166400) & \\
\hline \multirow[t]{2}{*}{36.5} & \multirow{2}{*}{$\begin{array}{l}\text { North Fork Stillaguamish River near Swede } \\
\text { Heaven, WA (streamgage 12166150) }\end{array}$} & 22.3 & \multirow{3}{*}{$\begin{array}{l}26.3 \\
24.1\end{array}$} & SR 530 bridge near Oso (Oso bridge) & \multirow{3}{*}{$\begin{array}{l}16.0 \\
14.7\end{array}$} \\
\hline & & & & 221st Avenue Bridge; NF Stillaguamish & \\
\hline 34.7 & C-Post bridge & 21.2 & & River at Oso, WA (streamgage 12166495) & \\
\hline 34.1 & Rollins Creek & 20.8 & 23.8 & Deer Creek & 14.5 \\
\hline \multirow[t]{2}{*}{34.0} & \multirow{2}{*}{$\begin{array}{l}\text { East side of new channel through SR } 530 \\
\text { Landslide deposit }\end{array}$} & \multirow[t]{2}{*}{20.7} & 16.1 & Railroad bridge at Cicero & 9.8 \\
\hline & & & 16.0 & SR 530 bridge near Cicero (Cicero bridge) & 9.8 \\
\hline 32.6 & $\begin{array}{l}\text { West side of new channel through SR } 530 \\
\text { Landslide deposit }\end{array}$ & 19.9 & 11.1 & $\begin{array}{l}\text { North Fork Stillaguamish River near } \\
\text { Arlington, WA (streamgage 12167000) }\end{array}$ & 6.8 \\
\hline 32.2 & $\begin{array}{l}\text { North Fork Stillaguamish River at Rowan, } \\
\text { WA (streamgage 12166240) }\end{array}$ & 19.6 & 4.8 & $\begin{array}{l}\text { Whitehorse Trail railroad bridge near } \\
\text { Arlington }\end{array}$ & 2.9 \\
\hline 29.7 & Montague Creek & 18.1 & 0.0 & South Fork Stillaguamish River confluence & 0.0 \\
\hline 29.1 & $\begin{array}{l}\text { Whitman Road bridge; North Fork } \\
\text { Stillaguamish River near Oso, WA } \\
\text { (streamgage 12166300) }\end{array}$ & 17.8 & 0.0 & Railroad bridge at Arlington & 0.0 \\
\hline
\end{tabular}

\section{Description of Study Area}

\section{Geography and Geology}

The North Fork Stillaguamish River Basin is located in the Cascade Range in northwestern Washington (fig. 1). The $736-\mathrm{km}^{2}$ basin ranges in elevation from 14 to $2,080 \mathrm{~m}$, and is characterized by steep, mountainous headwaters and a broad, glacially carved central valley. The river confluences with the South Fork Stillaguamish (drainage area $656 \mathrm{~km}^{2}$ ) in the city of Arlington to form the main-stem Stillaguamish River, which then flows another $28 \mathrm{~km}$ through the Puget Lowland before entering Puget Sound at Port Susan. The North Fork Stillaguamish River Basin is primarily underlain by Jurassic metamorphic and Eocene sedimentary rocks (Dragovich and others, 2003). During the Vashon Stade of the Fraiser Glaciation, approximately 16.5 thousand years ago (ka), the Puget Lobe of the Cordilleran ice sheet impounded the North Fork Stillaguamish River Basin, causing the valley to fill with silt- and clay-rich lacustrine material (Beechie and others, 2001). Valley-filling glaciers then overlaid a sequence of advance outwash, glacial till, and retreat outwash material. The river began to erode through these deposits after the retreat of the glacial lobe around $16.4 \mathrm{ka}$, incising to within meters of the modern river elevation by $12.5 \mathrm{ka}$ (Beechie and others, 2001; Lahusen and others, 2016). The relief created within these unconsolidated glacial deposits has created conditions conducive to landslides throughout the basin (Eide, 1990; Haugerud, 2014; Lahusen and others, 2016).

\section{River Characteristics and Geomorphic Study Reaches}

The main study area for the report includes the lower $56.5 \mathrm{~km}$ alluvial reaches of the North Fork Stillaguamish River, with a primary focus on the lower $39.1 \mathrm{~km}$ downstream of the landslide. Over those $39 \mathrm{~km}$, the North Fork Stillaguamish River is a single-threaded alluvial system, flowing primarily on a cobble bed. Reach-scale channel gradients range from 0.0017 to $0.0045 \mathrm{~m} / \mathrm{m}$, decreasing to $0.0010 \mathrm{~m} / \mathrm{m}$ near the confluence with the South Fork Stillaguamish River (table 3). Active channels widths range from 50 to $80 \mathrm{~m}$ in unconfined reaches, and sinuosities are generally between 1.3 and 1.5. Narrower and straighter reaches exist where the channel is confined by the Rowan Landslide, where it is confined by tertiary sediments near Arlington, and as of 2014, where it is confined by the SR 530 Landslide. 


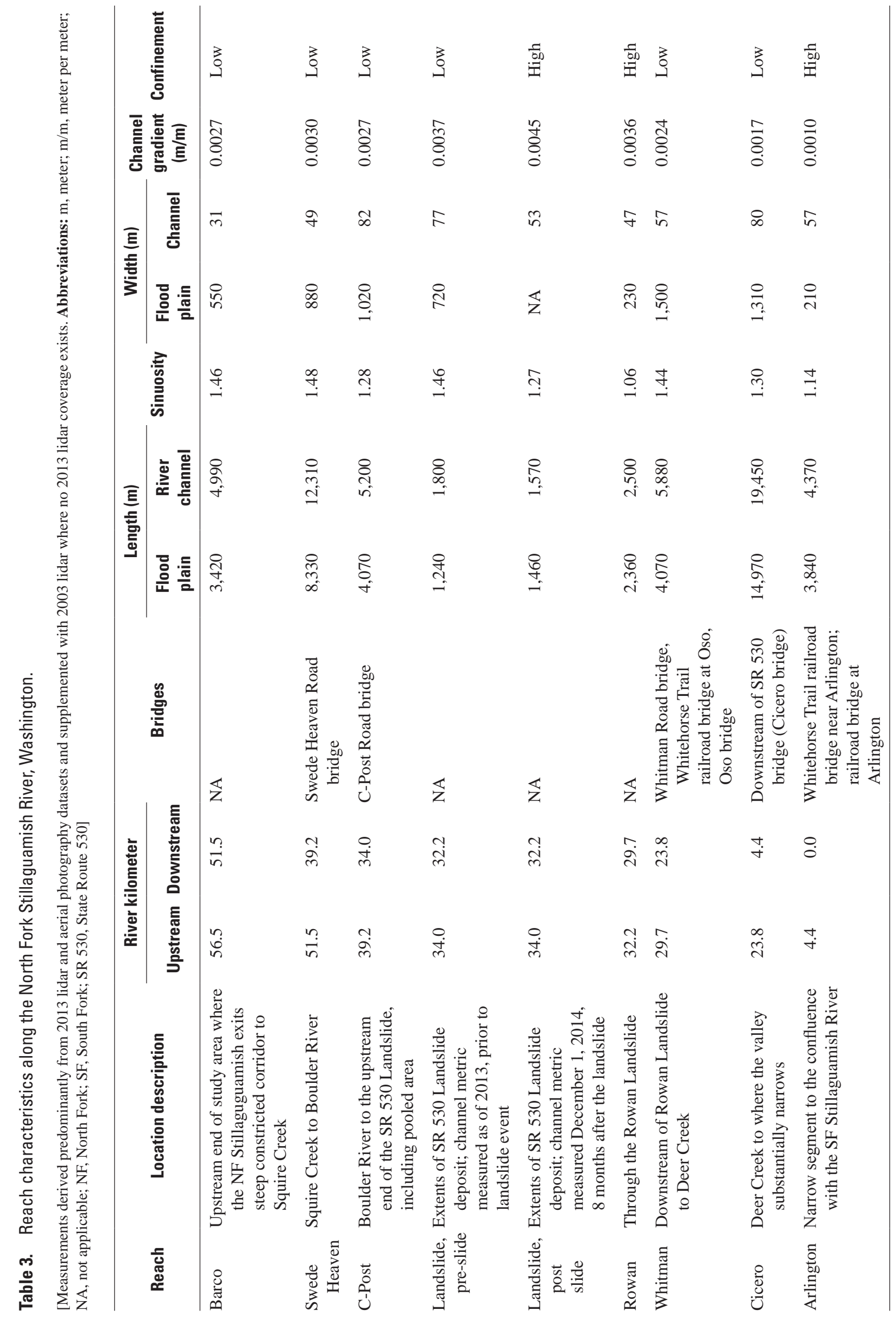


This study area is formally divided into eight reaches (table 3; figs. 4-5), providing a framework for discussing locations and channel character along the North Fork Stillaguamish River. Criteria for delineating reach boundaries are largely based on variation in water-surface gradient, channel and flood plain confinement, major tributaries, and recent landslide activity. Most of the information herein focuses on four reaches, presented in upstream to downstream order: (1) the 5.2-km C-Post reach, just upstream of the SR 530 Landslide, (2) the Landslide reach, encompassing the $1.8 \mathrm{~km}$ of channel directly affected by landslide deposition, (3) the Rowan reach, $2.5 \mathrm{~km}$ of narrow, straight channel confined by the 500 -year old Rowan Landslide (LaHusen and others, 2016), and (4) the 5.9-km Whitman reach, where the channel and flood plain again widen downstream of the Rowan Landslide and the mean gradient decreases slightly. The downstream end of the Whitman reach is defined by the confluence with Deer Creek, one of the larger tributaries to the North Fork Stillaguamish River and a significant source of sediment (Eide, 1990). Reaches farther downstream include the $19.4 \mathrm{~km}$ Cicero reach and $4.4 \mathrm{~km}$ Arlington reach. The Swede Heaven and Barco reaches are upstream of the C-Post reach. The Swede Heaven and Barco reaches, well upstream of the landslide, were assessed only by hydraulic and sediment-transport modeling and are presented to provide a broader basin-scale context for downstream results.

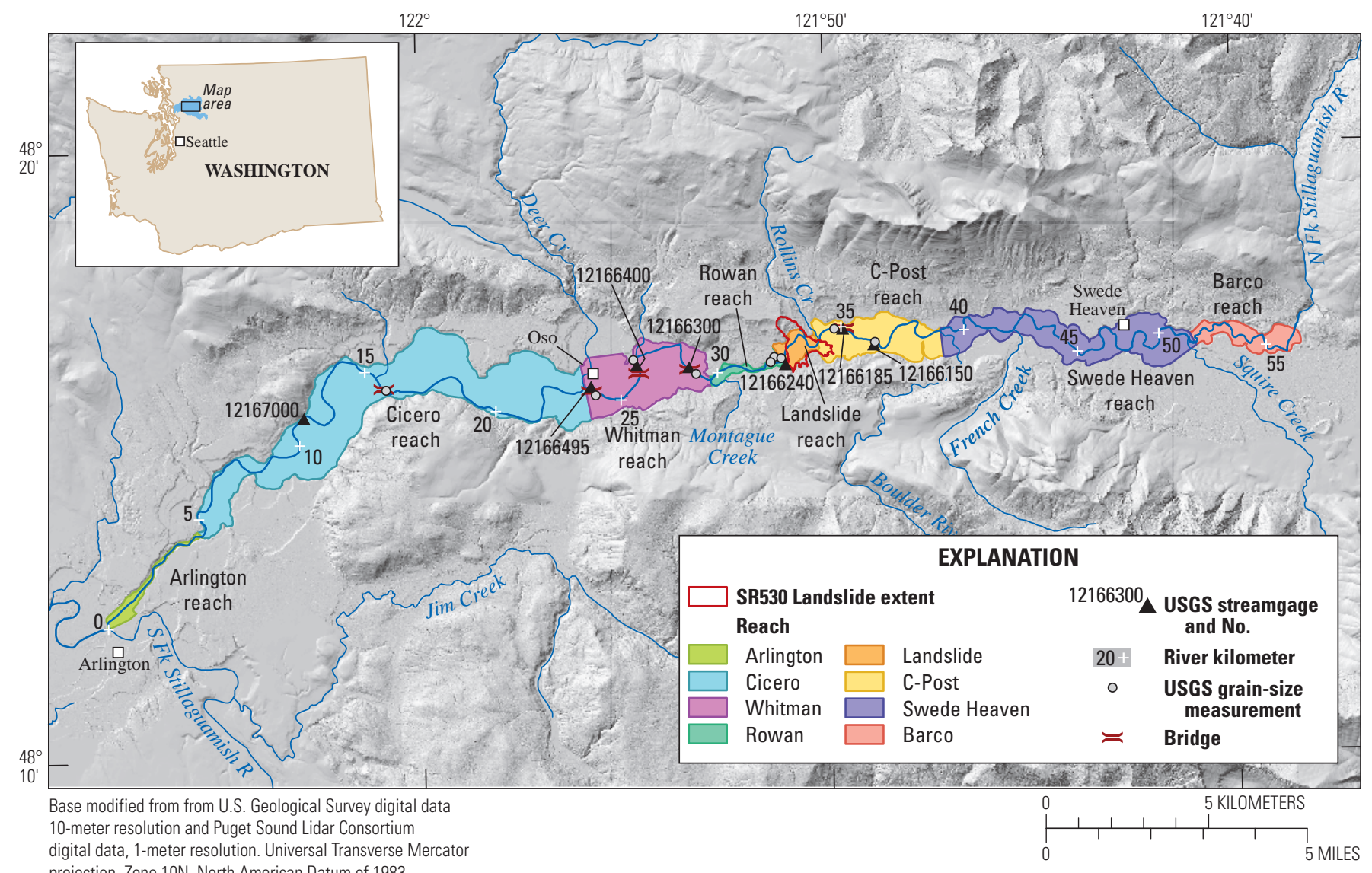

Figure 4. Study reaches, streamgages, and grain-size measurement sites on the North Fork Stillaguamish River, Washington. 


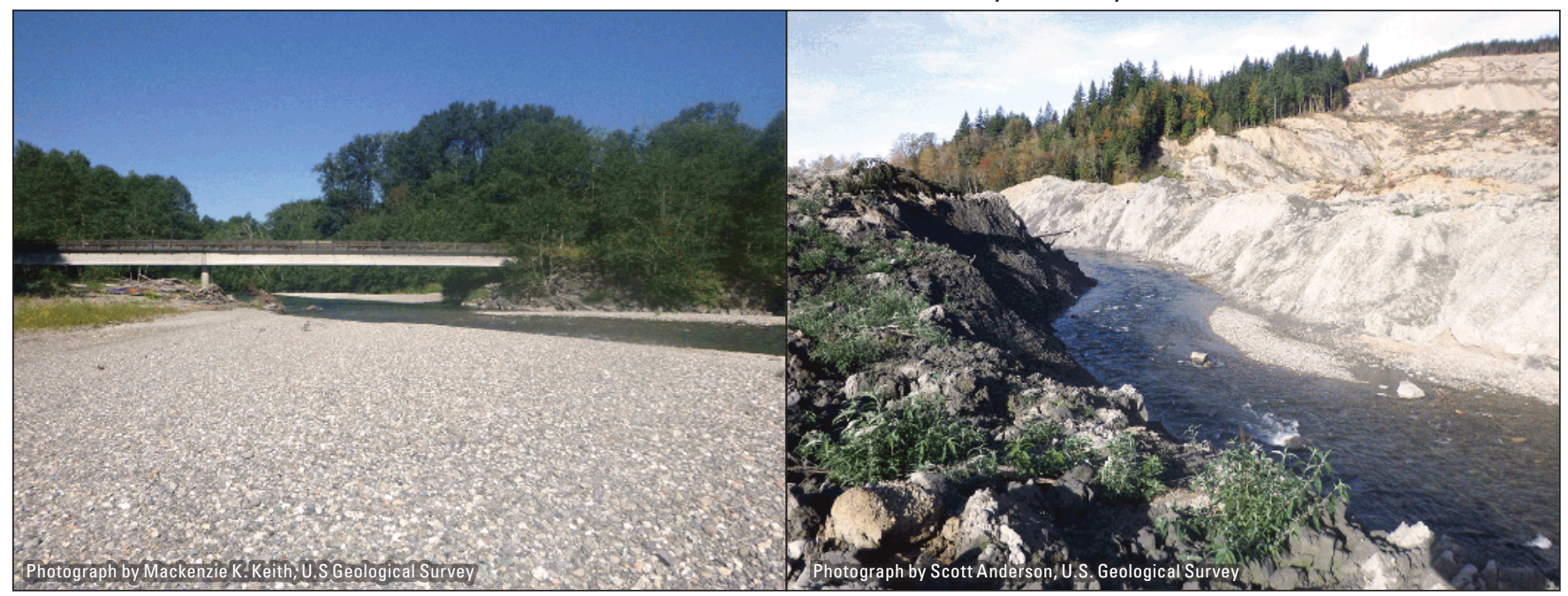

C. Rowan reach, July 14, 2014

D. Whitman reach, September 12, 2014

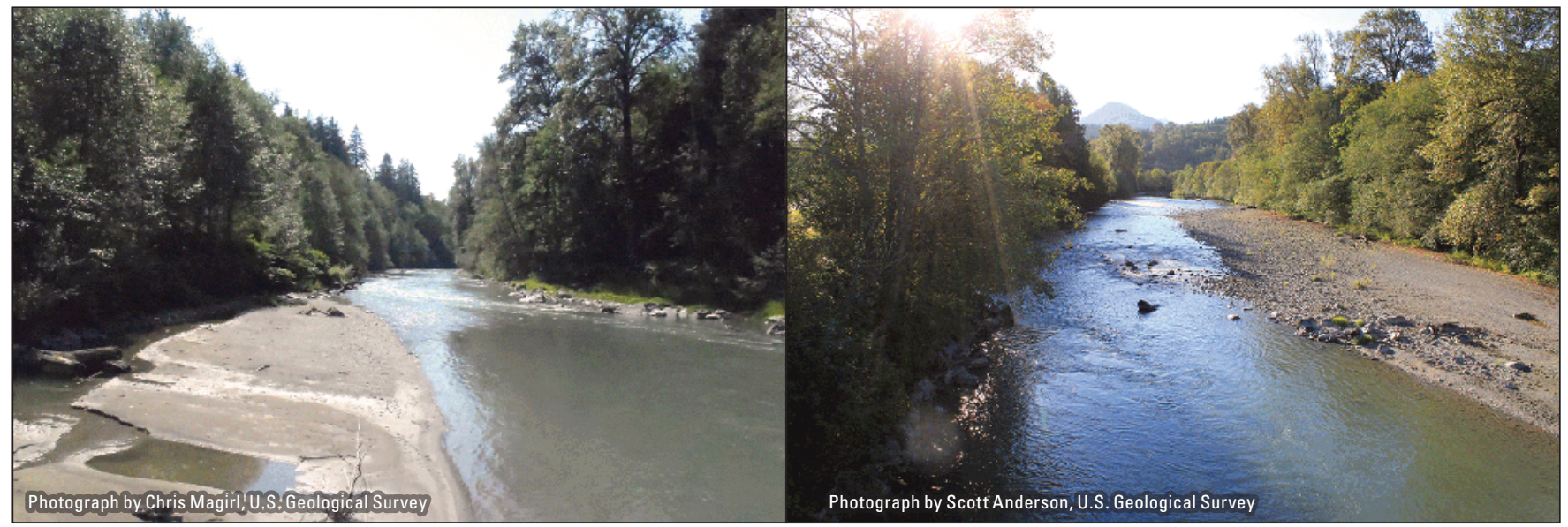

Figure 5. Typical channel conditions in the four primary study reaches along the North Fork Stillaguamish River, Washington. (A) C-Post reach, looking downstream toward C-Post Bridge. This area was within the impoundment lake extents, and was blanketed with sand in summer 2014. (B) Landslide reach prior to high flows of winter 2014-15 flood season, looking downstream from center of south side of the deposit. Channel width is about 20 meters and flanked by 10-meter-high banks. $(C)$ Rowan reach, looking downstream showing sand, silt, and clay from the landslide blanketing gravel bars. (D) Whitman reach, looking upstream from the Whitman Road Bridge. 


\section{Hydrology}

The hydrology of the North Fork Stillaguamish Basin was characterized by several streamgages in the basin, most of which were installed immediately after the landslide as part of the emergency response (table 4). Over the primary period of analysis for this study (March 22, 2014-September 30, 2015), newly installed USGS streamgages near Oso (12166300), located on the Whitman Road Bridge, herein referred to as the Whitman streamgage, and the streamgage near Swede Heaven (12166150), herein Swede Heaven, provided discharge information for the reaches in the immediate vicinity of the landslide (fig. 2). When referring to streamflow conveyed through the landslide, values are reported as recorded at Whitman. To characterize typical conditions in the North Fork Stillaguamish River over longer time scales, records from USGS streamgage near Arlington (12167000) were used, which provided a continuous period of record extending from water year 1929 to present. The Arlington streamgage is $23 \mathrm{~km}$ downstream of the landslide (fig. 1), and has a drainage area of just over one and half times that of the Whitman streamgage. Discharges at the two sites are highly correlated and scale by a factor similar to the drainage-area ratios (fig. 6).
The North Fork Stillaguamish River is a relatively flashy, rainfall-dominated system because of the low elevation of the basin and the lack of glaciated headwaters. Mean annual streamflows near Arlington typically are between 43 and $65 \mathrm{~m}^{3} / \mathrm{s}$ (1,500 and 2,300 ft³/s), and high flows occur most frequently between November and March during punctuated storm periods. During the study period, the monthly mean discharges and peak discharge were close to long-term median values (figs. 7-8). Discharges in the months after the landslide included numerous small discharge peaks between 70 and $110 \mathrm{~m}^{3} / \mathrm{s}\left(2,500\right.$ and 3,900 $\left.\mathrm{ft}^{3} / \mathrm{s}\right)$ before the onset of the summer low flow season (fig. 6B). The WY 2015 flood season included multiple peaks greater than $350 \mathrm{~m}^{3} / \mathrm{s}\left(12,400 \mathrm{ft}^{3} / \mathrm{s}\right)$. The peak flow for the study period occurred on November 26 , 2014 , with a peak flow of $420 \mathrm{~m}^{3} / \mathrm{s}\left(14,800 \mathrm{ft}^{3} / \mathrm{s}\right)$ at the Whitman streamgage. An analysis of flood records at Arlington by Magirl, Keith, and others (2015) indicates that the November 2014 peak discharge had an annual exceedance probability of about 0.5 , commonly referred to as a 2-year flood. Discharges began to decrease to record lows starting May 2015. Because little erosion and sediment transport typically occurs over the summer low-flow period, however, these record low discharges had little effect on the dynamics of landslide erosion and sediment transport.

Table 4. U.S. Geological Survey streamgages along the North Fork Stillaguamish River, Washington.

[Reach locations are shown in figure 4. Abbreviations NF, North Fork; WA, Washington; -, not applicable or no data]

\begin{tabular}{|c|c|c|c|c|c|c|}
\hline $\begin{array}{l}\text { Streamgage } \\
\text { No. }\end{array}$ & $\begin{array}{l}\text { Streamgage } \\
\text { name }\end{array}$ & $\begin{array}{l}\text { Abbreviated } \\
\text { name }\end{array}$ & Reach & $\begin{array}{l}\text { River } \\
\text { kilometer }\end{array}$ & Period of record & Available records \\
\hline 12166150 & $\begin{array}{l}\text { NF Stillaguamish River near } \\
\text { Swede Heaven, WA }\end{array}$ & Swede Heaven & C-Post & 36.5 & $03-27-14$ to $09-30-15$ & Stage, discharge, turbidity \\
\hline 12166185 & $\begin{array}{l}\text { NF Stillaguamish River at } \\
\text { C-Post Bridge near Oso, WA }\end{array}$ & C-Post & C-Post & 34.7 & $04-02-14$ to $09-30-15$ & Stage \\
\hline 12166240 & $\begin{array}{l}\text { NF Stillaguamish River at } \\
\text { Rowan, WA }\end{array}$ & Rowan & Rowan & 32.2 & $10-17-14$ to $09-30-15$ & Stage \\
\hline 12166300 & $\begin{array}{l}\text { NF Stillaguamish River near } \\
\text { Oso, WA }\end{array}$ & Whitman & Whitman & 29.1 & 03-24-14 to 09-30-15 & Stage, discharge, turbidity \\
\hline 12166400 & $\begin{array}{l}\text { NF Stillaguamish at Whitehorse } \\
\text { Trail near Oso, WA }\end{array}$ & Whitehorse & Whitman & 26.3 & $10-09-14$ to $09-30-15$ & Stage \\
\hline 12166495 & $\begin{array}{l}\text { NF Stillaguamish River at } \\
\text { Oso, WA }\end{array}$ & 221st Avenue & Whitman & 24.1 & $10-07-14$ to $09-30-15$ & Stage \\
\hline 12167000 & $\begin{array}{l}\text { NF Stillaguamish River near } \\
\text { Arlington, WA }\end{array}$ & Arlington & Cicero & 11.1 & 08-01-28 to $09-30-15$ & Stage, discharge \\
\hline 12170300 & $\begin{array}{l}\text { Stillaguamish River near } \\
\text { Stanwood, WA }\end{array}$ & Stanwood & - & - & $09-27-13$ to $09-30-15$ & Stage, discharge, turbidity \\
\hline
\end{tabular}


A. USGS streamgage 12167000, North Fork Stillaguamish near Arlington

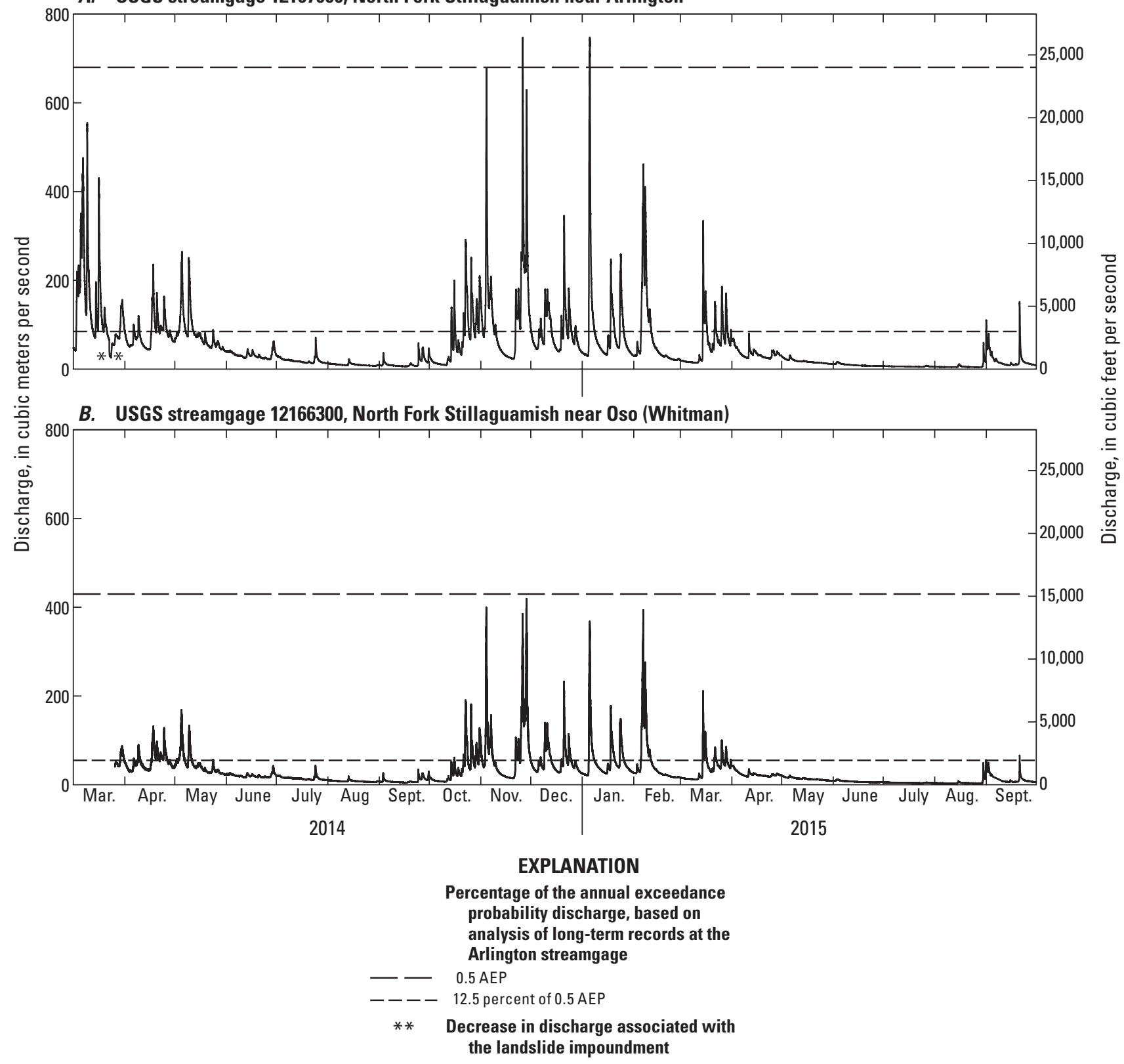

Figure 6. Discharge in 15-minute increments for streamgages $(A)$ North Fork Stillaguamish River near Arlington (12167000) and (B) North Fork Stillaguamish River near Oso (12166300; Whitman), Washington, March 2014-September 2015. Annual exceedance probability (AEP) discharges at Whitman are the values from Arlington scaled by the ratio of mean annual discharges at the two sites and does not reflect site-specific records. 


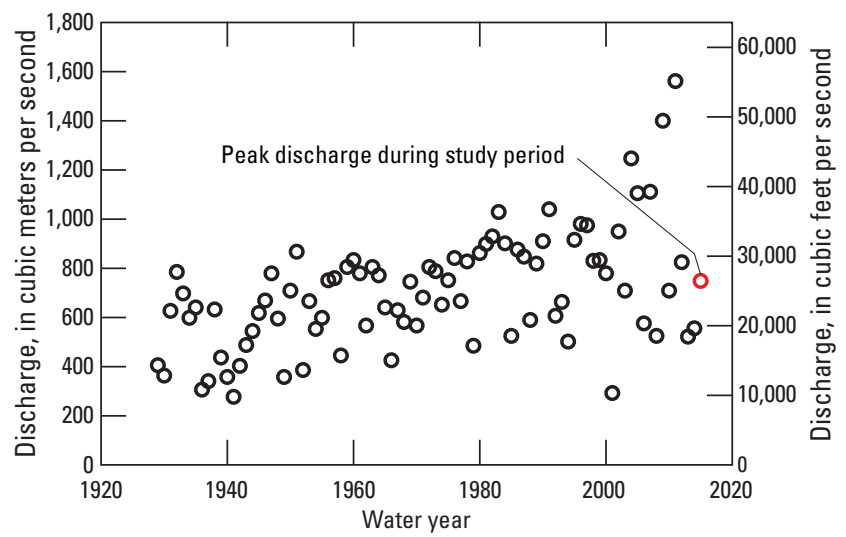

Figure 7. Annual instantaneous peak discharges at streamgage North Fork Stillaguamish near Arlington (12167000), Washington, for period of record and study period (2014-15).

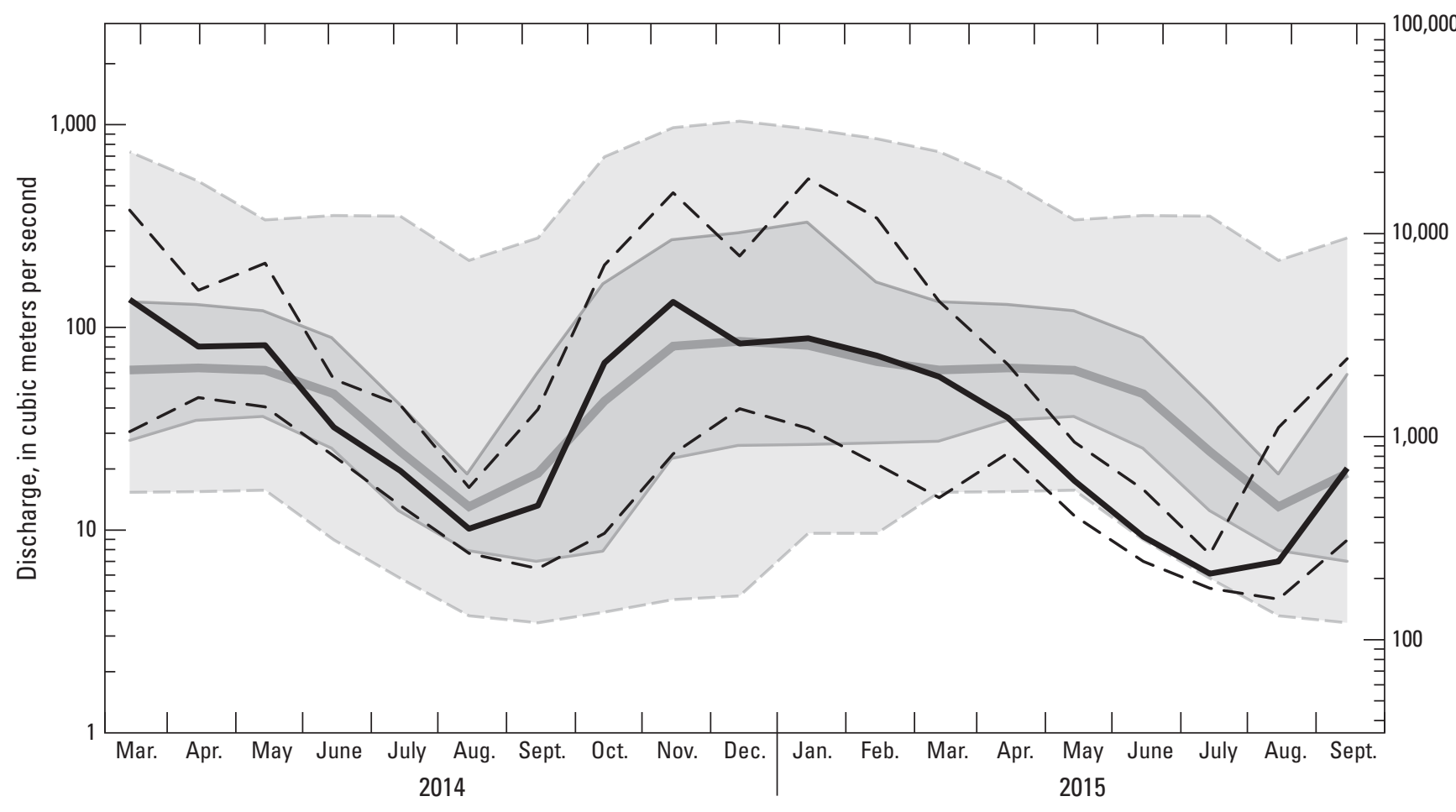

EXPLANATION

\section{Period of record (WY 1930-2013)}

Study period

Daily mean discharge for a given month unless otherwise noted

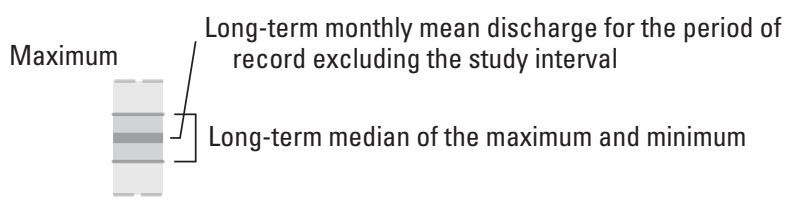

- Monthly mean discharge

- Minimum and maximum daily mean discharge for month

Minimum

Figure 8. Monthly mean discharge at North Fork Stillaguamish River at Arlington, Washington (USGS streamgage 12167000), March 2014-September 2015. Long-term median values are shown for comparison. The monthly discharges for March 2014 were not truncated prior to the date of the landslide (March 22), and so include several weeks of daily discharge values before the study interval. 


\section{Erosion of the State Route $\mathbf{5 3 0}$ Landslide Deposit}

The erosion of the SR 530 Landslide deposit, which started when the North Fork Stillaguamish River overtopped the impoundment a little more than 1 day after the landslide, provided a substantial source of sediment to downstream reaches. Repeat high-resolution topographic surveys were used to quantify the quantity of material eroded from the deposit over time, and document the processes by which that material was eroded. The extents of various sediment types, referred to here as facies, present in the deposit were mapped and the bulk density and grain-size distribution of those facies were characterized to better quantify the mass and caliber of delivered sediment and assess how facies characteristics may influence erosion rates and processes.

\section{Data Collection and Analysis Methods}

\section{Pre-Existing Data}

Aerial light detection and ranging (lidar) data acquired in 2013 provided topography of the river and the landslide site prior to the landslide on March 22, 2014 (table 1). Following the landslide, the Washington State Department of Transportation (WSDOT) acquired aerial lidar on March 24 and April 6, 2014. Bathymetric surveys of the impoundment lake were done in early April 2014 and merged with the April 6 lidar data to provide continuous elevation data for both subaerial and submerged sections of the landslide deposit (Magirl, Keith, and others, 2015). WSDOT also collected five sets of high-resolution aerial imagery datasets between March 24 and July 1, 2014. After July 1, 2014, all topographic and photographic surveys of the landslide were acquired by the USGS using Structure from Motion photogrammetry.

\section{Structure from Motion Photogrammetry}

Structure from Motion (SfM) photogrammetry is a recently developed technique for deriving high-resolution topography from photographic images. Early assessments have demonstrated high-quality results using broadly accessible software and equipment that provided a low-cost/low-effort alternative to lidar or differential Global Navigation Satellite System (GNSS) surveys (Westoby and others, 2012; Fonstad and others, 2013; Javernick and others, 2014). Like traditional photogrammetry, SfM, uses photographs of the same scene from different perspectives to derive the three-dimensional structure of that scene. SfM differs from traditional photogrammetry in using modern computer vision techniques to automatically identify and match congruent points across many photographs that may be taken at various distances from the scene and from variable, arbitrary perspectives. By matching thousands of points, the algorithm can automatically reconstruct an initial estimate of both camera poses (position and orientation) and the scene geometry. This initial estimate, which rests in arbitrary image-space coordinates, then can be translated into real-world coordinates using known camera positions or surveyed ground control points.

Eight SfM surveys of the landslide deposit were acquired between July 1, 2014, and July 7, 2015. Imagery from July 1, 2014, was collected by WSDOT and provided to the USGS. All further photographic acquisitions, starting November 1, 2014, were completed by the USGS. Surveys were acquired opportunistically after floods or after a sequence of moderate discharge events. The interval between surveys ranged from about 1 week to more than 3 months. Each survey produced a DEM with a horizontal resolution of between 0.25 and $0.5 \mathrm{~m}$, and a digital orthoimage with a horizontal resolution of about $0.1 \mathrm{~m}$. Comparison with an independent Real Time KinematicGlobal Navigation Satellite System (RTK-GNSS) survey and cross-comparisons of the SfM digital elevation models (DEMs) in stable regions of the landslide deposit indicated that the precision of the elevation data was about $0.2 \mathrm{~m}$, with little (less than $0.05 \mathrm{~m}$ ) systematic error. Additional details regarding the methods of photographic acquisition, processing, and error assessments are presented in appendix A. DEMS are available through Anderson (2017).

\section{Analysis of Channel Geometry}

The sequence of 10 DEMs and 14 orthoimages acquired between March 24, 2015, and July 7, 2015, was used to quantify the evolution of the channel width and the water-surface elevation of the North Fork Stillaguamish River through the landslide deposit. The channel width was delineated along the bottom of the bounding banks. In the March 24 and April 6, 2014, lidar surveys, acquired before the channel had eroded through the entire width of the deposit, channel widths were measured only to the location of clear channelization. Water-surface elevations were extracted from aerial lidar surveys directly along the channel centerline. To extract a water-surface profile from SfM data, which often produced noisy and inaccurate results over moving water, the elevation of low-gradient exposed surfaces at the edge of the water was manually identified and measured at regular intervals. To account for water-surface profile differences related to stage, water-surface profiles after July 2014 were normalized to match the low-flow conditions of the January 29, 2015 survey by uniformly subtracting the mean difference in stage for the given survey date and January 29, 2015, as recorded at the Swede Heaven, Rowan, and Whitman streamgages (table 5). Surveys prior to July 2014 were not normalized because the change in elevation related to erosion was substantially larger than stage variability related to discharge. 
Table 5. Differences in water-surface elevation, relative to January 29, 2015 conditions, at selected streamgages near the SR 530 Landslide, North Fork Stillaguamish River, Washington.

[Water-surface elevations, in meters above North American Vertical datum of 1988, throughout the landslide area were uniformly shifted by the average value to reduce discharge-related differences in stage. Abbreviations m, meter; -, no data]

\begin{tabular}{ccccc}
\hline \multirow{2}{*}{$\begin{array}{c}\text { Survey } \\
\text { date }\end{array}$} & \multicolumn{2}{c}{ Difference in water-surface elevation (m) } & \\
\cline { 2 - 4 } & $\begin{array}{c}\text { Swede Heaven } \\
\mathbf{( 1 2 1 6 6 1 5 0 )}\end{array}$ & $\begin{array}{c}\text { Rowan } \\
\mathbf{( 1 2 1 6 6 2 4 0 )}\end{array}$ & $\begin{array}{c}\text { Whitman } \\
\mathbf{( 1 2 1 6 6 3 0 0 )}\end{array}$ & \\
\hline $07-01-14$ & -0.05 & - & -0.08 & -0.07 \\
$11-01-14$ & 0.31 & 0.68 & 0.58 & 0.52 \\
$11-10-14$ & 0.22 & 0.18 & 0.24 & 0.21 \\
$12-01-14$ & 0.26 & 0.22 & 0.23 & 0.23 \\
$01-06-15$ & 0.51 & 0.66 & 0.69 & 0.62 \\
$01-29-15$ & 0.00 & 0.00 & 0.00 & 0.00 \\
$03-18-15$ & 0.04 & -0.02 & 0.07 & 0.03 \\
$07-07-15$ & -0.42 & -0.21 & -0.48 & -0.37 \\
\hline
\end{tabular}

\section{Assessing Volumetric Erosion}

Volumetric erosion of the landslide deposit was estimated by differencing repeat topographic surveys to create DEMs of Difference (DoDs). Prior to differencing, all raster images were projected into the North American Datum of 1983 (NAD 83) in Universal Transverse Mercator coordinates and registered to a common grid to ensure exactly coincident cells. All DEMs were measured relative to the North American Vertical Datum of 1988 (NAVD 88) and converted to orthometric elevations using GEOID12A. Once nominally in the same coordinate system, the surveys were assessed for registration errors that may arise because of minor errors in GNSS data used for georeferencing. Because the goal of this effort was detecting change, the accuracy of the results depended only on the accuracy of the co-registration, as opposed to the absolute registration, of the paired DEMs. This allowed for arbitrary selection of one of the two DEMs for "ground truth" to which the second DEM was aligned. This alignment was done on the basis of overlapping areas of topography where the true change was presumed to be zero. Vertical offsets were identified and corrected based on the mean change in relatively flat regions of the deposit where the true change was judged to be zero. Mean vertical offset corrections were generally less than $0.05 \mathrm{~m}$. Horizontal offsets were assessed following the approach of Nuth and Kääb (2011), which makes use of the fact that horizontal co-registration offsets produce systematic vertical offsets that vary as a function of the slope and aspect of a surface. The relation between the full three-dimensional co-registration errors and the observed vertical offset can be calculated as

$$
\Delta h=\Delta x \tan (\sin (\alpha) \theta)+\Delta y \tan (\cos (\alpha) \theta)+\Delta z
$$

where

$\Delta \mathrm{h}$ is the observed vertical offset at a cell, $\Delta \mathrm{x}, \Delta \mathrm{y}$, and $\Delta \mathrm{z}$ are the co-registration errors in the respective directions, $\alpha$ is the local aspect, and $\theta$ is the local slope.

The $\sin (\alpha) \theta$ and $\cos (\alpha) \theta$ terms represent the east-west and north-south components of the slope, respectively. Values of $\Delta h, \alpha$, and $\theta$ are all calculable from the raw data, allowing for the use of linear regression to estimate the co-registration error terms ( $\Delta \mathrm{x}, \Delta \mathrm{y}$, and $\Delta \mathrm{z})$ and uncertainty bounds around those estimates. No statistically significant horizontal offsets were determined when aligning SfM data to SfM data, likely because all datasets were registered to the same ground-control network. The March 22, and April 6, 2014 lidar were relatively offset in both the $\mathrm{x}$ and $\mathrm{y}$ direction on the order of $0.4 \mathrm{~m}$, whereas the April 6, 2014, lidar and July 1, 2014, SfM were offset in the $\mathrm{x}$ and $\mathrm{y}$ directions 0.2 and $0.4 \mathrm{~m}$, respectively.

After DEMs were aligned and final DoDs created, the geomorphically active extents of the deposit were visually delineated and the volumetric change within those areas were quantified by multiplying the vertical change at a given raster cell by the area of the raster cell. A more complete description of these methods and how the changes over submerged areas were quantified are presented in the appendix A. The uncertainty in our estimates of volumetric change related to survey accuracy and precision were assessed following the methods of Lane and others (2003) with an additional component of uncertainty related to the potential presence of residual systematic errors, similar to East and others (2015). A conservative presumption was that systematic errors as large as $0.05 \mathrm{~m}$ may have remained despite the co-registration process, and that the precision (defined by the standard deviation of the noise within individual measurements) of both lidar and SfM surveys was $0.20 \mathrm{~m}$ (see appendix A). Propagated uncertainties for all survey intervals typically were less than 10 percent of measured change, and decrease to about 3 percent when compared with total change over the study period. The small percentage uncertainties are a function of the large magnitude of true change during the erosion of the new landslide channel, and indicate that survey errors are not likely to have substantial influence on the findings presented here.

\section{Characterizing Sediment Characteristics of the Landslide Deposit}

The landslide deposit was composed of relatively distinct zones of sediment types, referred to herein as facies, that reflected the various stratigraphic units contained within the pre-failure hillslope (Riemer and others, 2015). The erodibility and sediment size of these various facies exert a strong 
control on the planform stability of the new channel, and define the caliber of material introduced into the river as these units erode. For that reason, the spatial extents and sediment characteristics of the various facies over the extents of the valley floor were characterized. A map of the surficial extents of the various facies was developed based on a combination of aerial photography, lidar imagery, and field verification to identify areas of similar grain-size character and bulk density. Mapping was limited to five general units, with a focus on outwash, till, and lacustrine material as described in table 6 . Advance recessional outwashes were not differentiated, both of which were present in the hillslope and deposit and were composed of distinct grain-size distributions (Keaton and others, 2014; Reimer and others, 2015; Wartman and others, 2016). However, based on the mapping efforts just cited as well as field observations, most outwash material in the near-channel zone was the finer-grained recessional outwash. Grain-size distributions for each of the three primary facies of interest (outwash, till, and lacustrine) were measured through a combination of field sieving to quantify the coarse fraction and laboratory grain-size analysis of the finer material, done by the Cascade Volcano Observatory (CVO) sediment laboratory. Bulk density measurements of the outwash material were made in the field, whereas bulk density measurements of the lacustrine material were done by the CVO sediment laboratory on submitted samples. No bulk-density measurements of the till were made.

\section{Evolution of Channel Geometry}

The North Fork Stillaguamish River overtopped the landslide deposit 25 hours after the initial failure (Magirl, Keith, and others, 2015), initiating channel development. The steep channel gradient associated with the abrupt drop in local base level at the western edge of the deposit resulted in steady incision. The upstream extent of channelization, marked by a steep knickzone, migrated $250 \mathrm{~m}$ into the deposit within the first day following overtopping, and had traversed $700 \mathrm{~m}$-most of the deposit—within 1 week (fig. 9). As the knickzone reached the eastern edge of the deposit, the river initially began incising through a stretch of riparian forest, intersecting the impoundment pool near the outlet of Rollins Creek (fig. 10). That initial channel alignment was manually altered with the construction of a pilot channel located along the eastern margin of the deposit, outside of the forested flood plain, to hasten impoundment drainage and limit the downstream delivery of large woody debris. The 350-m-long pilot channel was constructed between April 8 and 30, 2014, and connected the naturally incised channel to the impoundment pool along a planform location similar to the pre-landslide river position. Construction involved the excavation of about $20,000 \mathrm{~m}^{3}$ of material, which was placed on the left bank of the channel (Drew, Dan, and Dave Porter, BCI Contracting, Inc., written commun., 2015). All flow was captured by the pilot channel by the end of April 2014 (Magirl, Keith, and others, 2015).

Table 6. Generalized geologic units, descriptions, and grain-size characteristics from field and laboratory analyses of deposit material of the SR 530 Landslide along the North Fork Stillaguamish River, Washington.

[Mapping units were generalized from previous geologic mapping and unit descriptions in Dragovich and others (2003) and Keaton and others (2014), as well as field observations; lidar, light detection and ranging]

\begin{tabular}{|c|c|c|}
\hline Unit & Description & Diagnostic features \\
\hline Alluvium & $\begin{array}{l}\text { Main river corridor along NF Stillaguamish } \\
\text { River composed of channel bed and gravel } \\
\text { bars }\end{array}$ & $\begin{array}{l}\text { Wetted channel and bright, new bare gravel bars; maps } \\
\text { representative of conditions on July 1, } 2014\end{array}$ \\
\hline $\begin{array}{l}\text { Debris runout, mixed } \\
\text { sediment }\end{array}$ & Mixed sediment runout & $\begin{array}{l}\text { Relatively high variability in color and lidar intensity } \\
\text { from remote sources; generally low amplitude } \\
\text { hummocks and flat zones toward the southern area } \\
\text { of interest }\end{array}$ \\
\hline Glacial outwash & $\begin{array}{l}\text { Generally unconsolidated sands with some } \\
\text { larger rounded clasts to about cobble size }\end{array}$ & $\begin{array}{l}\text { Oxidized, sandy material; varies from dominantly } \\
\text { sand to unconsolidated sand with rounded gravel } \\
\text { and cobbles }\end{array}$ \\
\hline Glacial till & $\begin{array}{l}\text { Variable grain sizes, but typically sandy (loose) } \\
\text { to sand matrix with angular gravel sized clast; } \\
\text { boulder clasts/inclusions should be rare }\end{array}$ & $\begin{array}{l}\text { Gray appearance and blocky texture in aerial } \\
\text { photography }\end{array}$ \\
\hline Glacial lacustrine & Dense, clay material & $\begin{array}{l}\text { Grayish-blue appearance in aerial photography, } \\
\text { relatively low intensities, and large surficial areas } \\
\text { exposed near post-slide river corridor }\end{array}$ \\
\hline
\end{tabular}




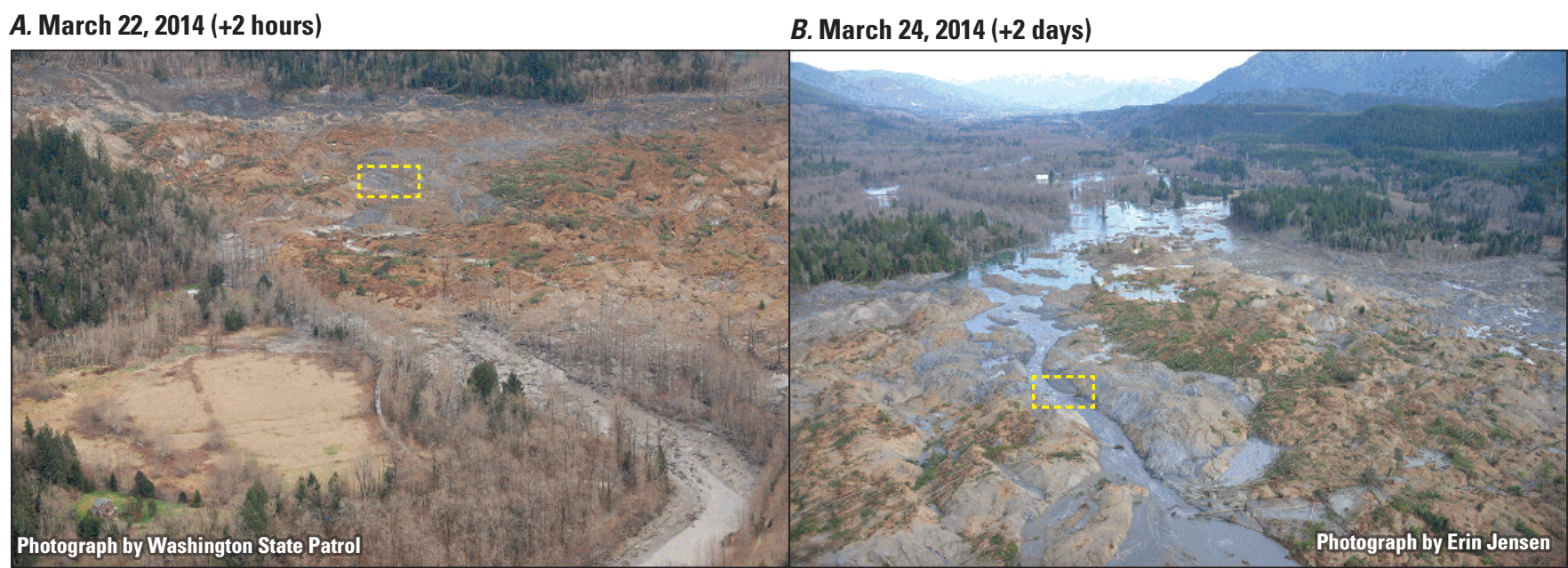

\section{March 30, 2014 (+8 days)}

\section{May 7, 2014 (+6 weeks)}

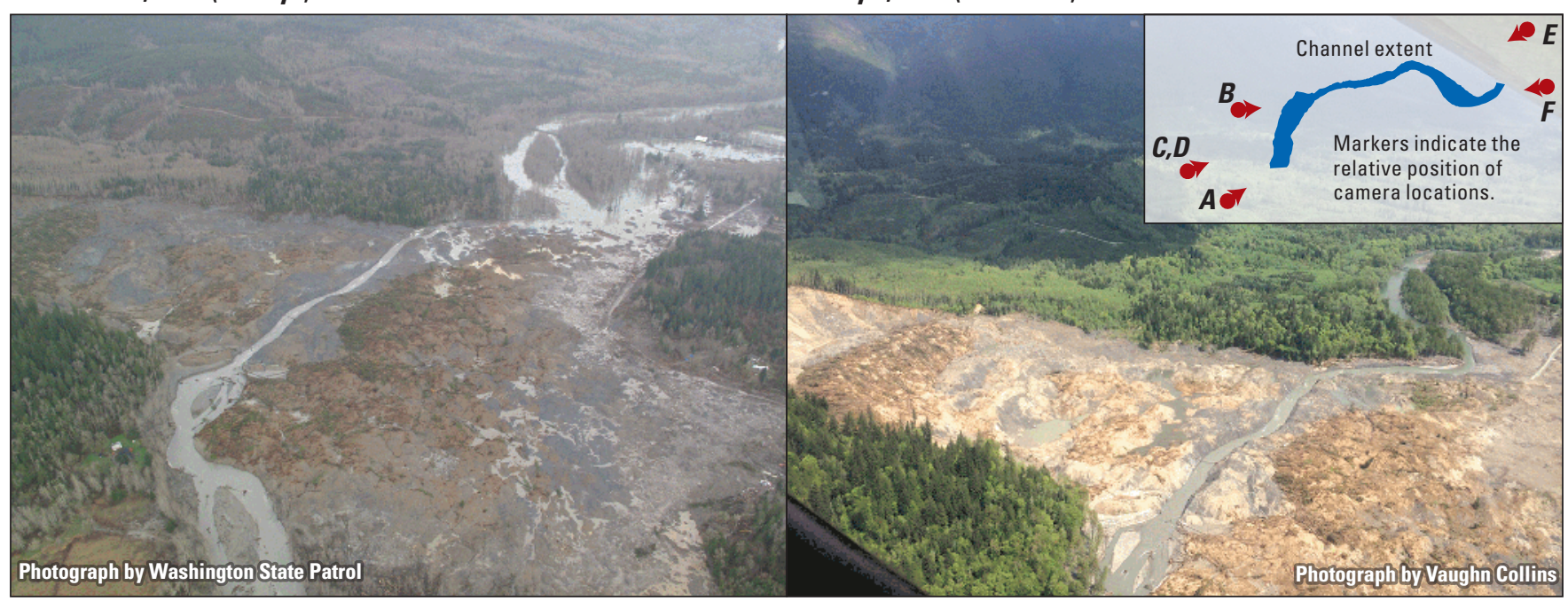

\section{E. May 7, 2014 (+6 weeks)}

\section{F. January 29, 2015 (+10 months)}

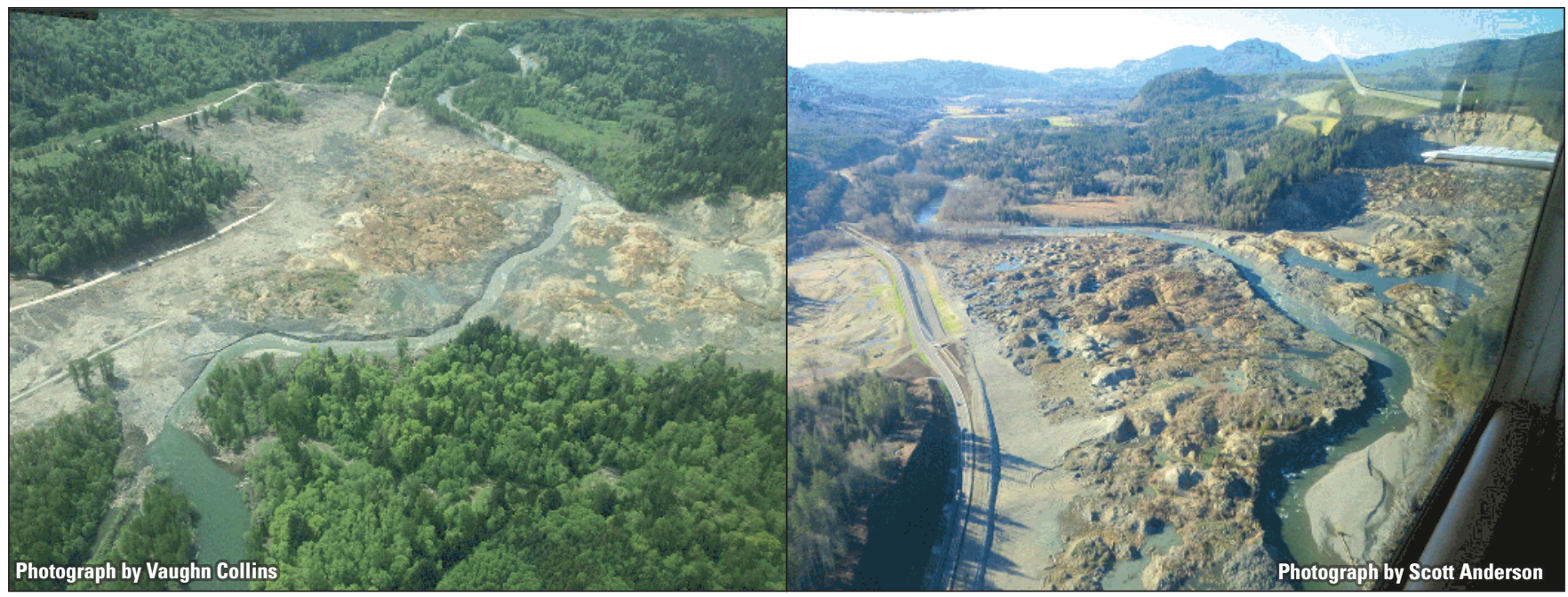

Figure 9. Oblique aerial photographs showing re-establishment of a channel through the SR 530 Landslide deposit along the North Fork Stillaguamish River near 0so, Washington. Dashed box in $(A)$ indicates the location of the channel-spanning tree seen in $(B)$ for reference. Little geomorphic change occurred after January 29, 2015; conditions in $(F)$ are similar to conditions at the end of the study period. 


\section{A. March 24, 2014}

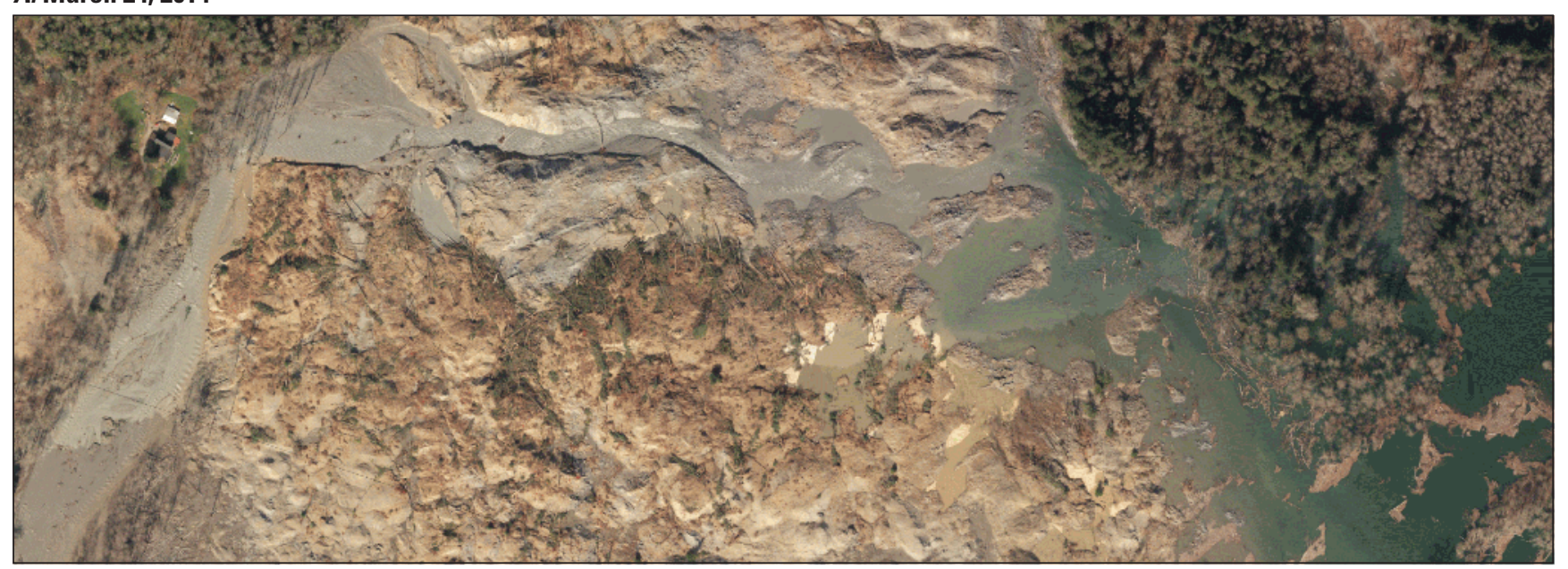

\section{B. July 1, 2014}

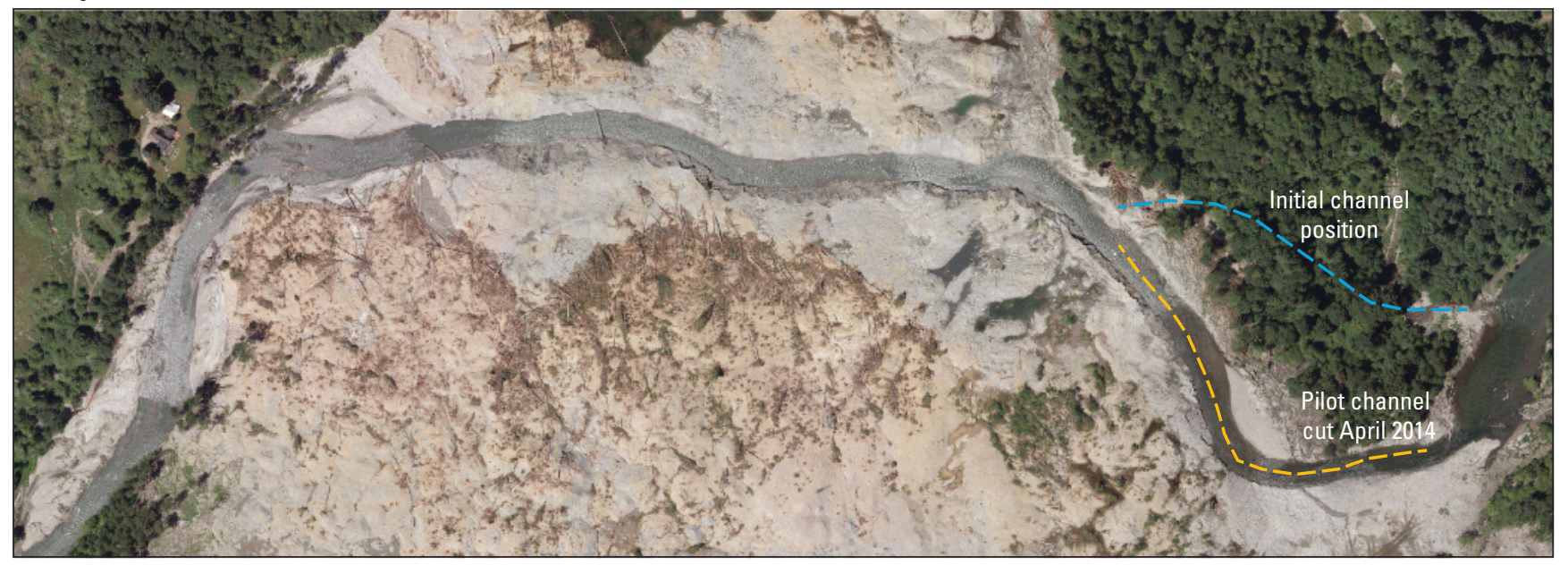

C. July 7, 2015

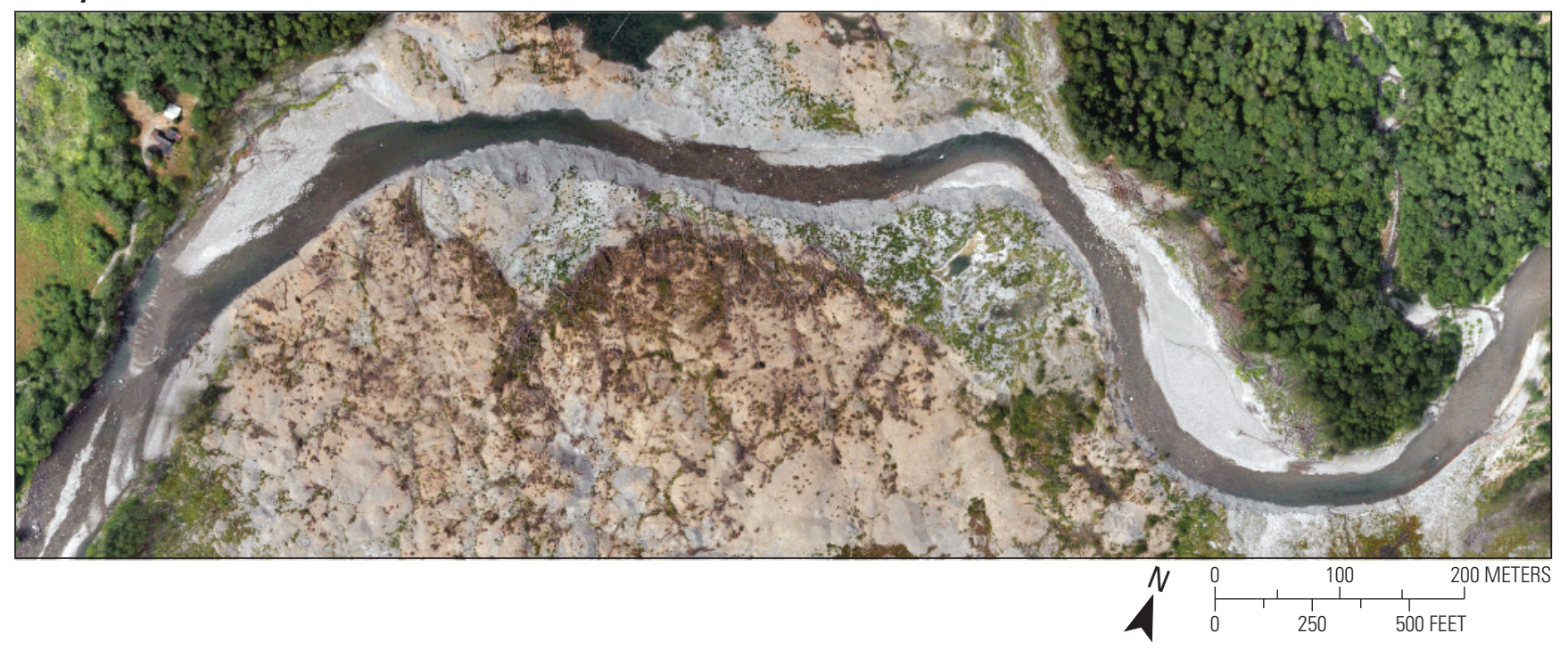

Figure 10. Repeat orthoimages showing evolution of the new channel through the landslide deposit along the North Fork Stillaguamish River near Oso, Washington. Images for $(A)$ March 24, 2014, and $(B)$ July 1, 2014, were acquired by the Washington State Department of Transportation. Image for $(C)$ July 7, 2015, is Structure from Motion-derived orthoimagery from this study. 
The water surface in the new channel through the landslide deposit was an average of $7 \mathrm{~m}$ above the pre-landslide water-surface profile on March 24, 2014, but incised vertically through most of the depth of the landslide deposit in the first several months after the initial overtopping (figs. 11-12). The river incised an average of $4 \mathrm{~m}$ between March 24 and April 6, 2014, and incised another $2 \mathrm{~m}$ between April 6 and July 1, 2014, topographic surveys. Field observations indicate that most of the incision in the latter period occurred prior to mid-May and the onset of summer low flows (fig. 6). Magirl, Keith, and others (2015) also noted that ponding upstream of the landslide deposit was no longer visually evident for moderate to low discharges about mid-May. The channel remained vertically stable during the first months of WY 2015, which included several flows greater than $350 \mathrm{~m}^{3} / \mathrm{s}$, but then incised $0.5 \mathrm{~m}$ between January 6 and 29, 2015, when no discharges exceeded $180 \mathrm{~m}^{3} / \mathrm{s}$ (fig. 12). This incision likely resulted from the propagation of a secondary knickzone through the landslide deposit, formed as the high flows in early January moved the western edge of the channel laterally (fig. 10). As of July 2015, the latest date for which surveys were available, the water-surface elevation through the landslide reach was an average of $0.5 \mathrm{~m}$ greater than the pre-landslide profile, primarily as a result of the persistent aggradation of about $1 \mathrm{~m}$ over the $0.5 \mathrm{~km}$ reach at and just downstream of the western edge of the deposit (fig. 11).

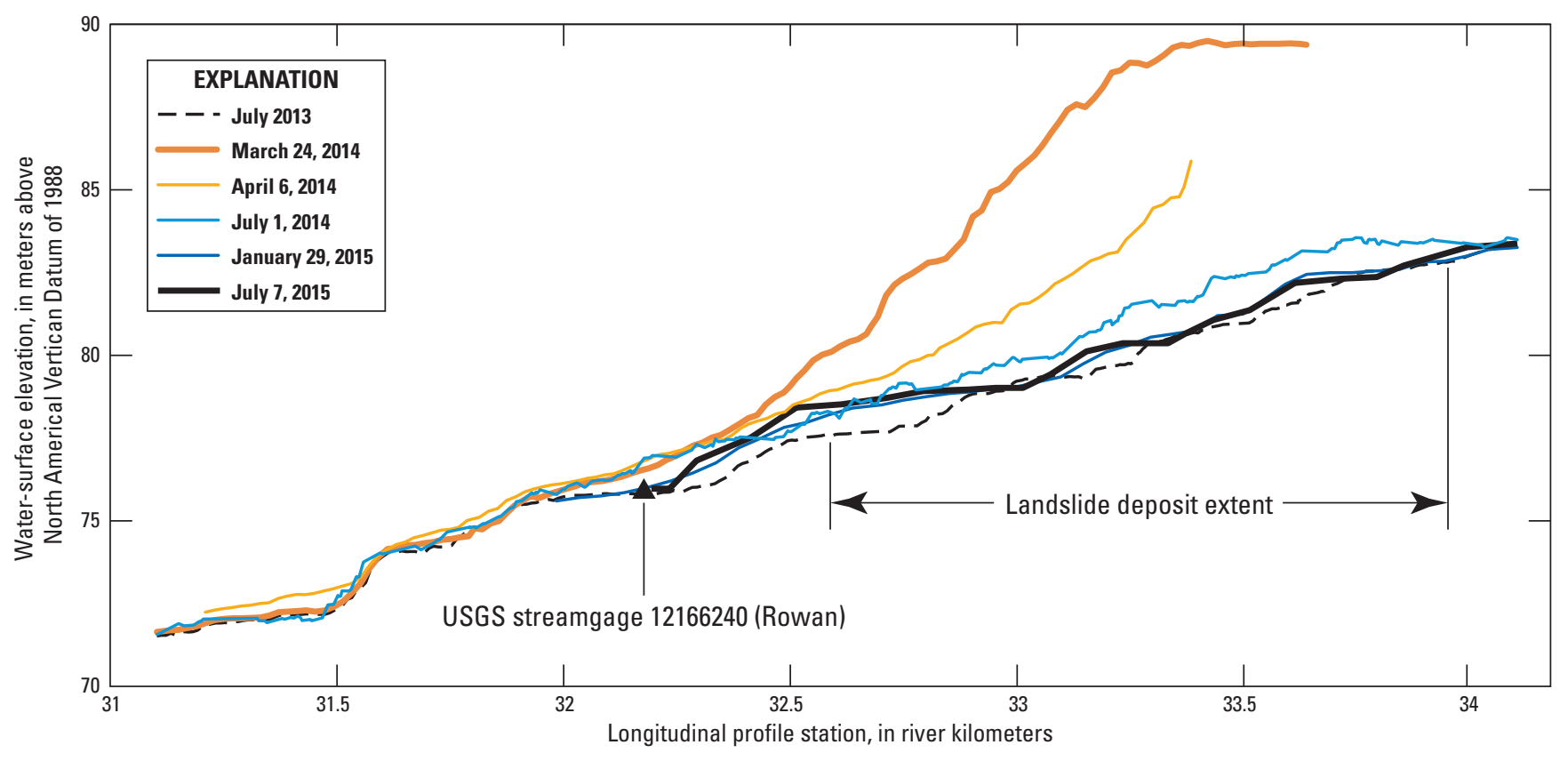

Figure 11. Water-surface elevation through the landslide reach and the immediate downstream reach along the North Fork Stillaguamish River, Washington. Profiles obtained July 1, 2014, and July 7, 2015, were shifted to minimize minor discharge-dependent variations in stage to match conditions in the survey on January 29, 2015 (see table 5). 


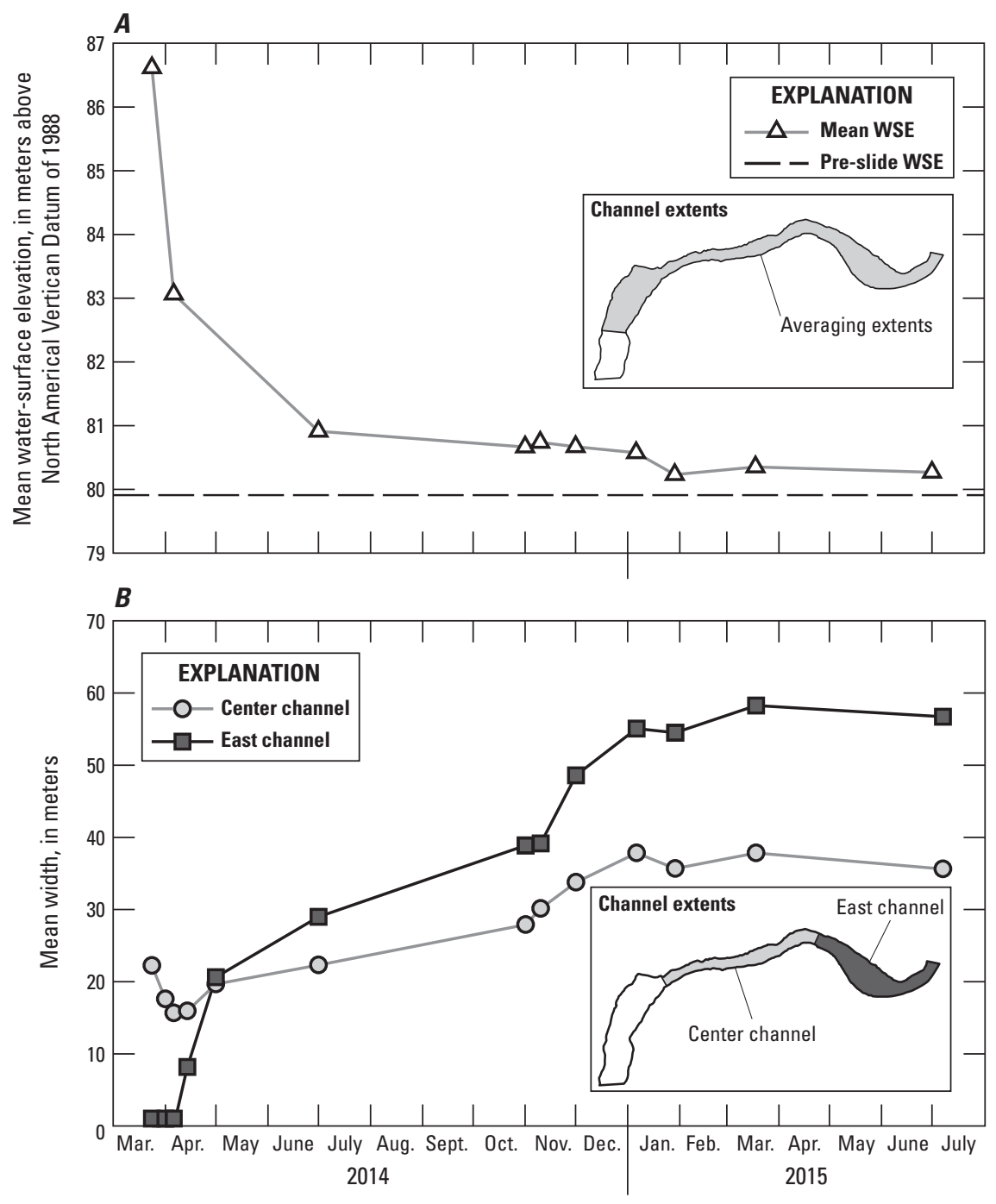

Figure 12. Changes in $(A)$ mean water-surface elevation (WSE) and $(B)$ mean channel width through the landslide deposit along the North Fork Stillaguamish River, Washington, March 2014-July 2015. Water-surface elevations have been shifted to minimize discharge-dependent variations in water-surface elevation (see table 5).

The channel widened appreciably over the study period, although the central subreach through the landslide deposit remained narrow and confined relative to undisturbed reaches upstream of the deposit as of July 2015. Mean channel width actually decreased in the first weeks after the landslide, although this trend reflects the averaging of new, narrow channel as the knickzone migrated upstream more than an actual decrease in width at any given location (figs. 12-13). At the onset of 2014 summer low flows, the mean width of the central channel was approximately $20 \mathrm{~m}$. The eastern channel widened more rapidly as the constructed channel bend migrated west. The central channel doubled in width to $38 \mathrm{~m}$ between October 2014 and early January 2015 in response to high flows. Left and right banks eroded at similar rates, and the channel centerline moved little (figs. 14-15). During this same period, the eastern channel continued to migrate westward and widened to a mean width of $60 \mathrm{~m}$. No additional increases in channel width occurred between January and July 2015, and included periods where mean width decreased slightly when the steep banks supplied more material to the channel edges than the river was able to entrain. 


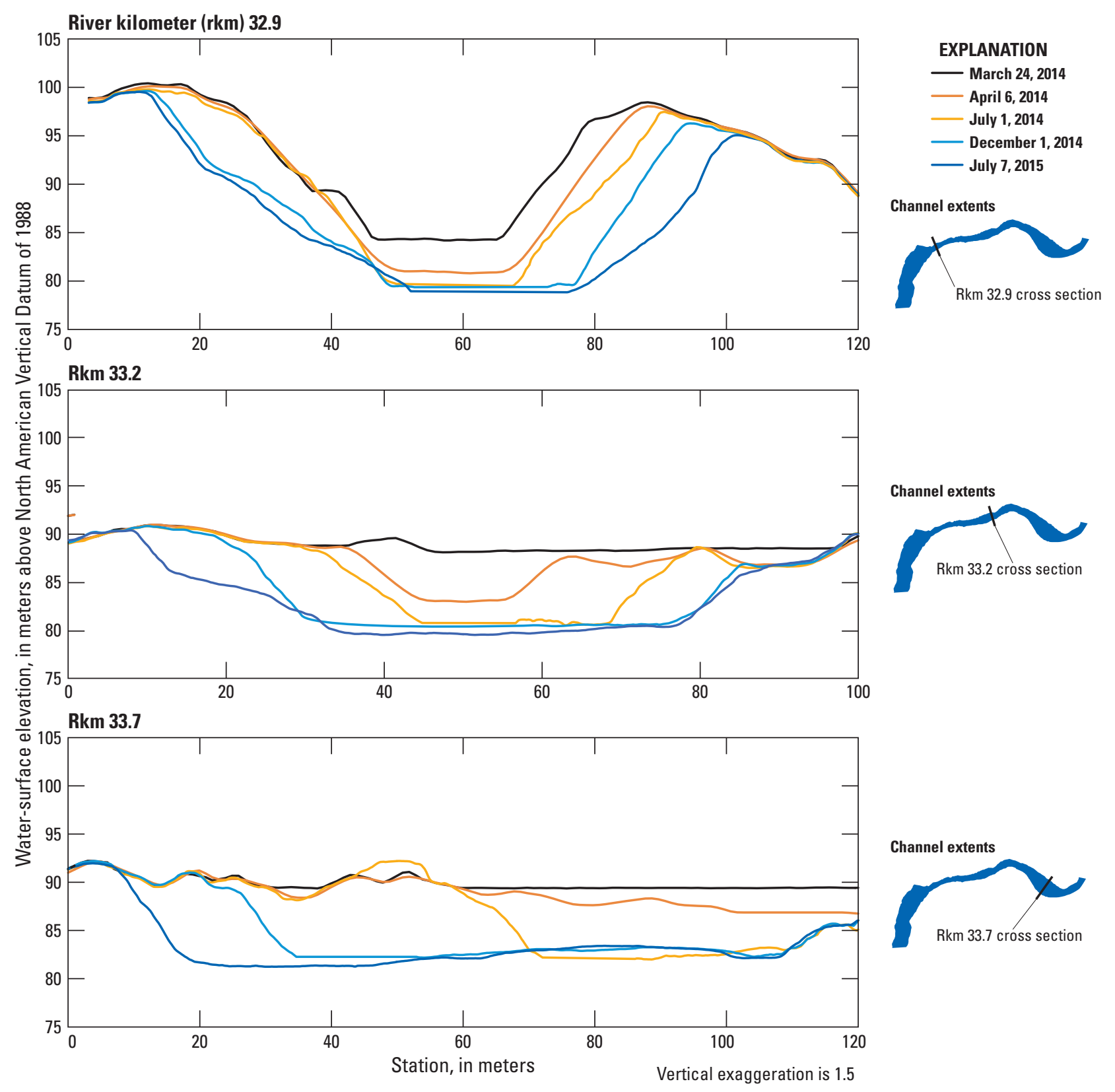

Figure 13. Repeat cross-section profiles of the newly eroded channel of the North Fork Stillaguamish River, Washington. Cross sections show the water-surface elevation and do not contain any information about submerged bed elevations, except for the cross section for April 6, 2014, at rkm 33.7. 
A. September 9, 2014

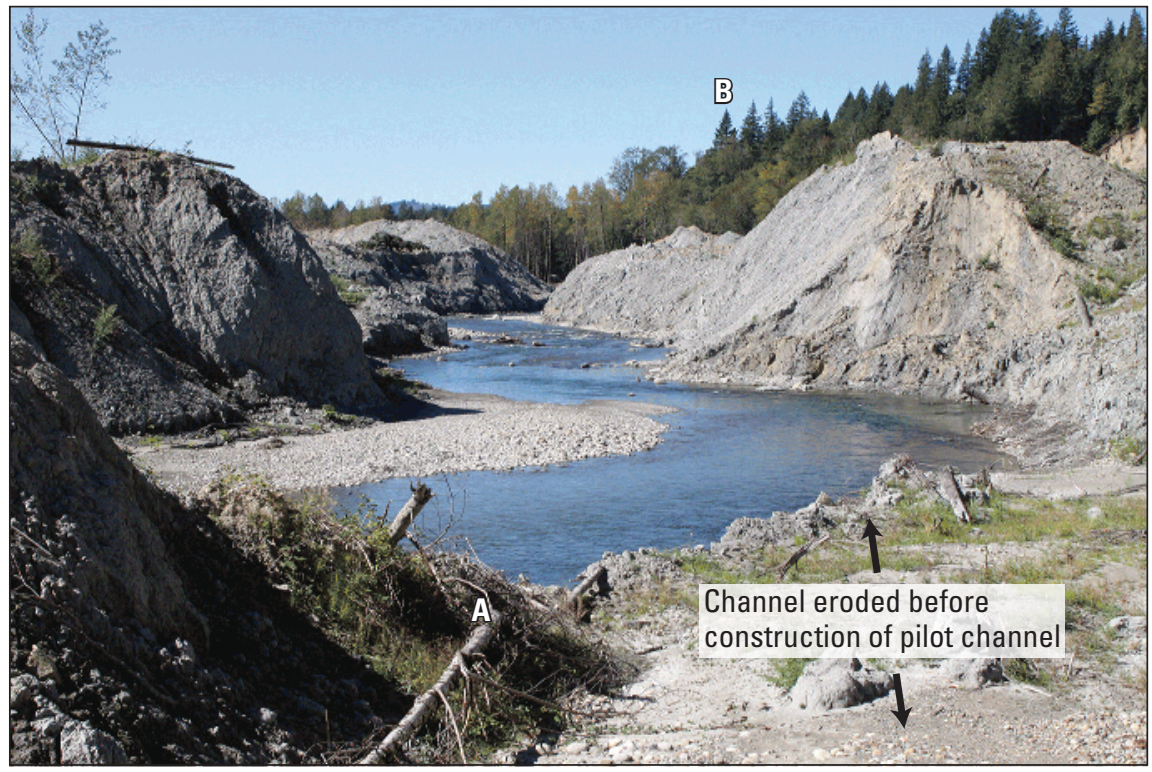

\section{B. January 29, 2015}
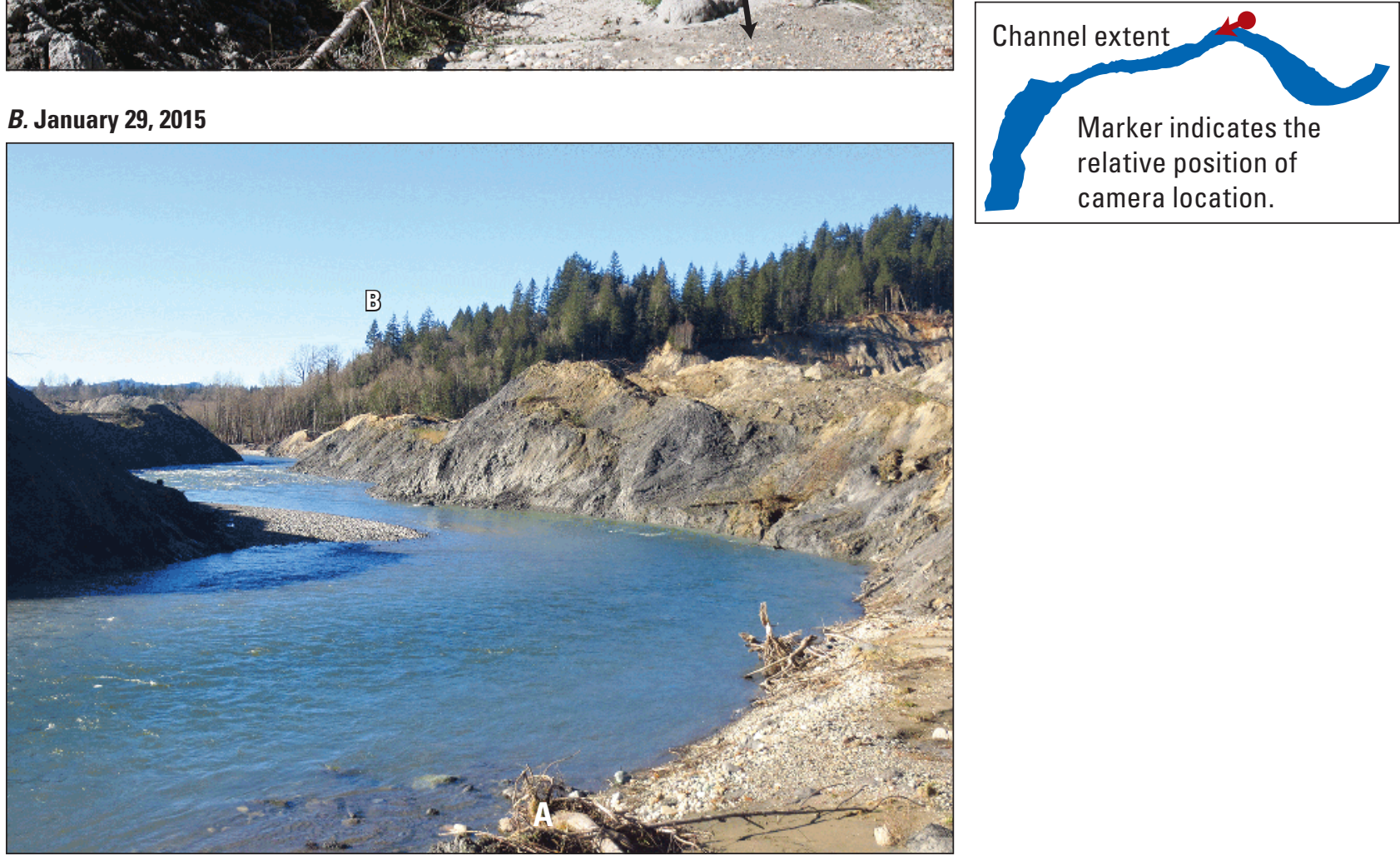

Figure 14. New channel through the landslide deposit along the North Fork Stillaguamish River, Washington, September 9, 2014, and January 29, 2015. Photographs were taken from the bottom of the original channel alignment, which was abandoned after the construction of the pilot channel. Letters in photographs indicate coincident objects. The September 9, 2014, photograph shows the channel prior to the 2014-15 winter flood season. Little channel change occurred between January 29, 2015, and the end of the study period. The January 29, 2015, photograph approximately represents the channel conditions at the end of the study. 

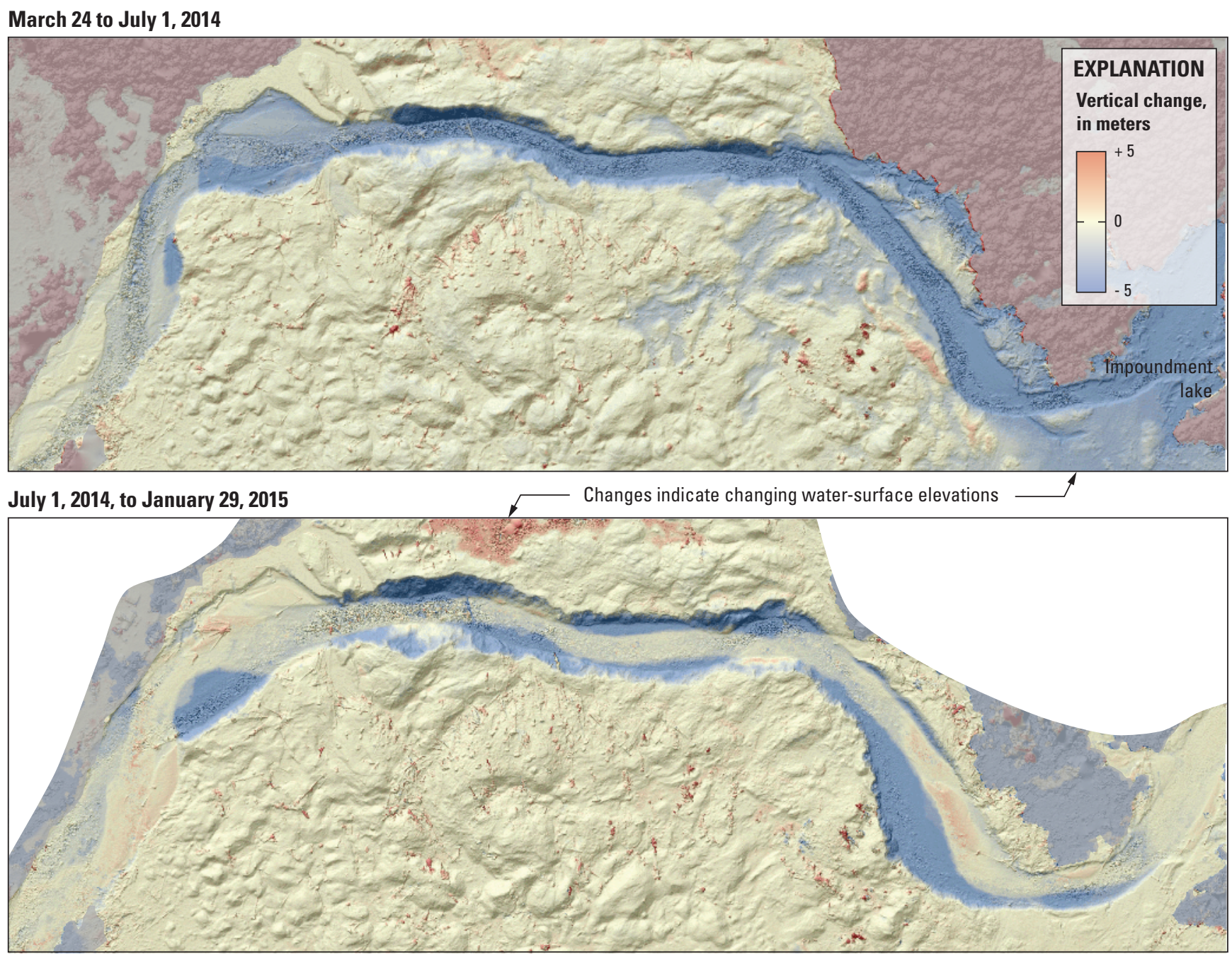

\section{January 29 to July 7, 2015}

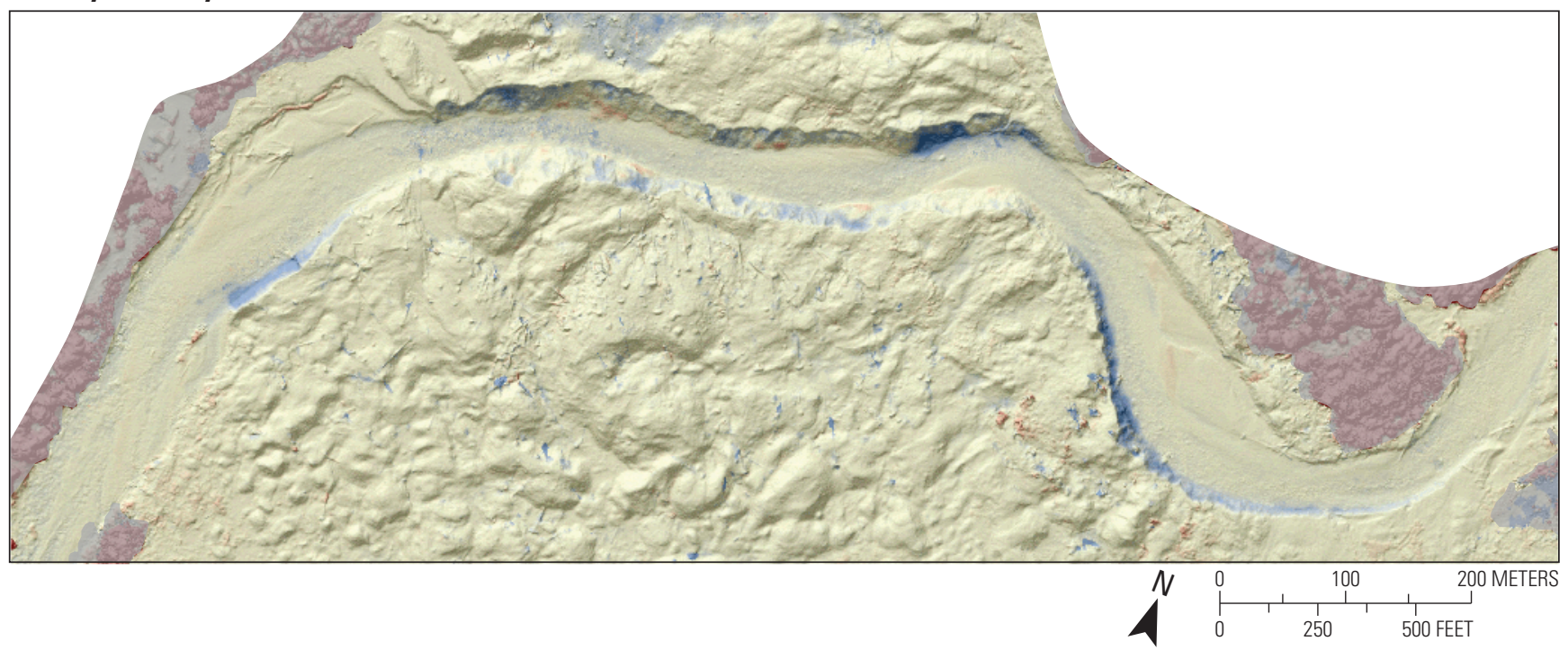

Figure 15. Vertical change in SR 530 Landslide deposit based on topographic differencing, North Fork Stillaguamish River, Washington. Underlying topography for each panel is the later of the difference datasets. Change in shaded areas along the margins of the surveys is a result of either variable reconstruction of the forest canopy in Structure from Motion (SfM) data, or the differencing of a lidar-derived bare earth terrain model with a SfM-derived surface model, and does not represent true geomorphic change. Lowering on the eastern edge of the deposit surface between March 24 and July 1, 2014, is a result of the draining of the impoundment lake. Change in the center of the northern side of the deposit is a result of changing water levels in a sag pond. 


\section{Sediment Characteristics and Erosion Processes}

The newly incised channel was located within a zone of primarily lacustrine material, and field observations and aerial photography indicated that lacustrine material made up the largest proportion of the exposed banks during the entire period of analysis (figs. 16-17). Banks composed of outwash were observed at the western and eastern edges of the deposition. Till was not observed in significant quantities along the channel corridor. Over the course of the study, continued erosion of the banks provided new exposures of the vertical composition of the deposit, and locations mapped surficially as lacustrine material generally were vertically homogeneous. However, lacustrine material was also underlying outwash material along banks at both the western and eastern edges of the deposit (fig. 17D), and commonly was underlying other units in auger probes, indicating that the estimate of the extents of lacustrine material based on surficial mapping likely underestimates the true fraction of lacustrine material within the deposit.

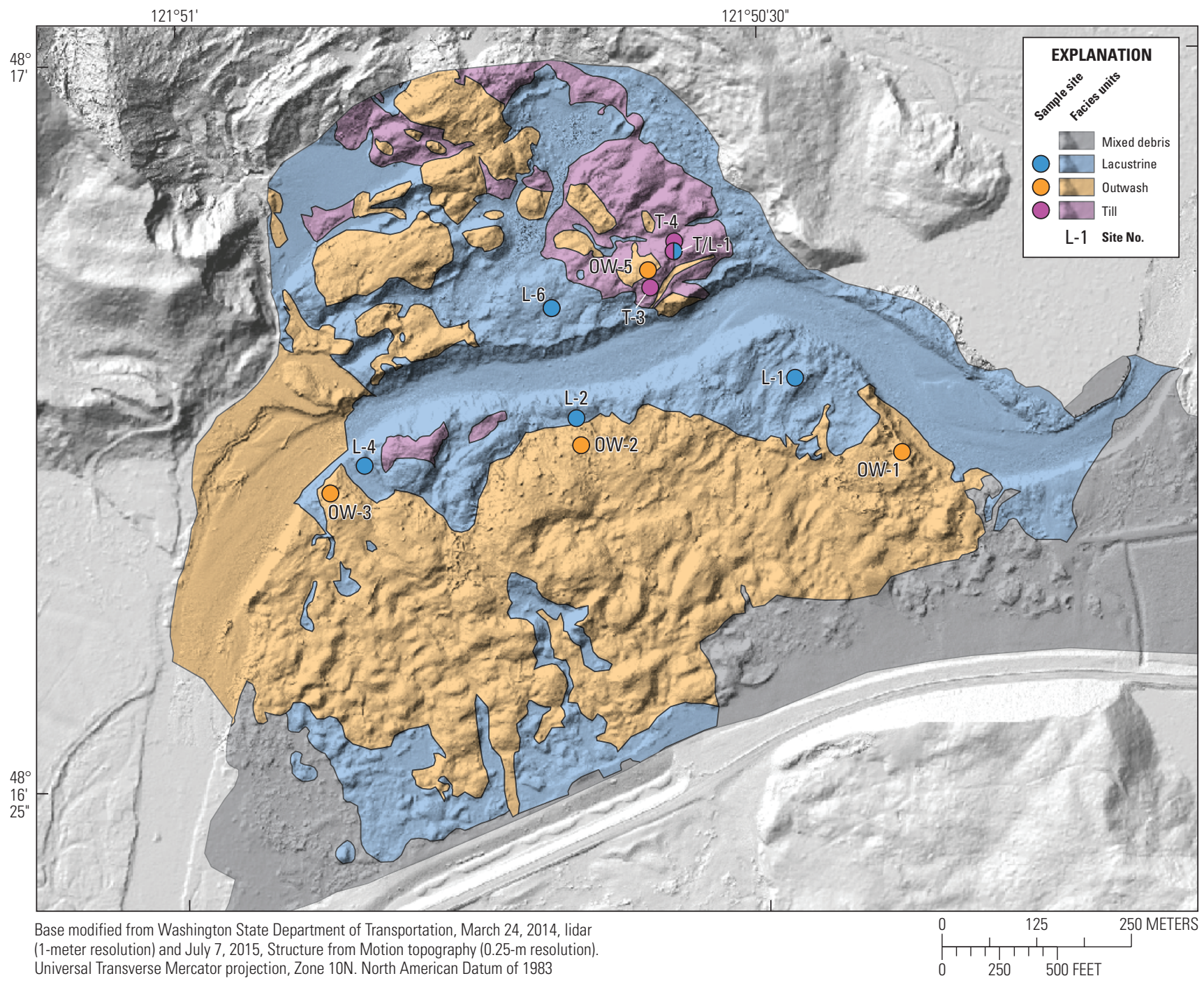

Figure 16. Surficial sample sites and generalized facies units determined from field and remote sources, SR 530 Landslide area, North Fork Stillaguamish River, Washington, autumn and winter 2014-15. 


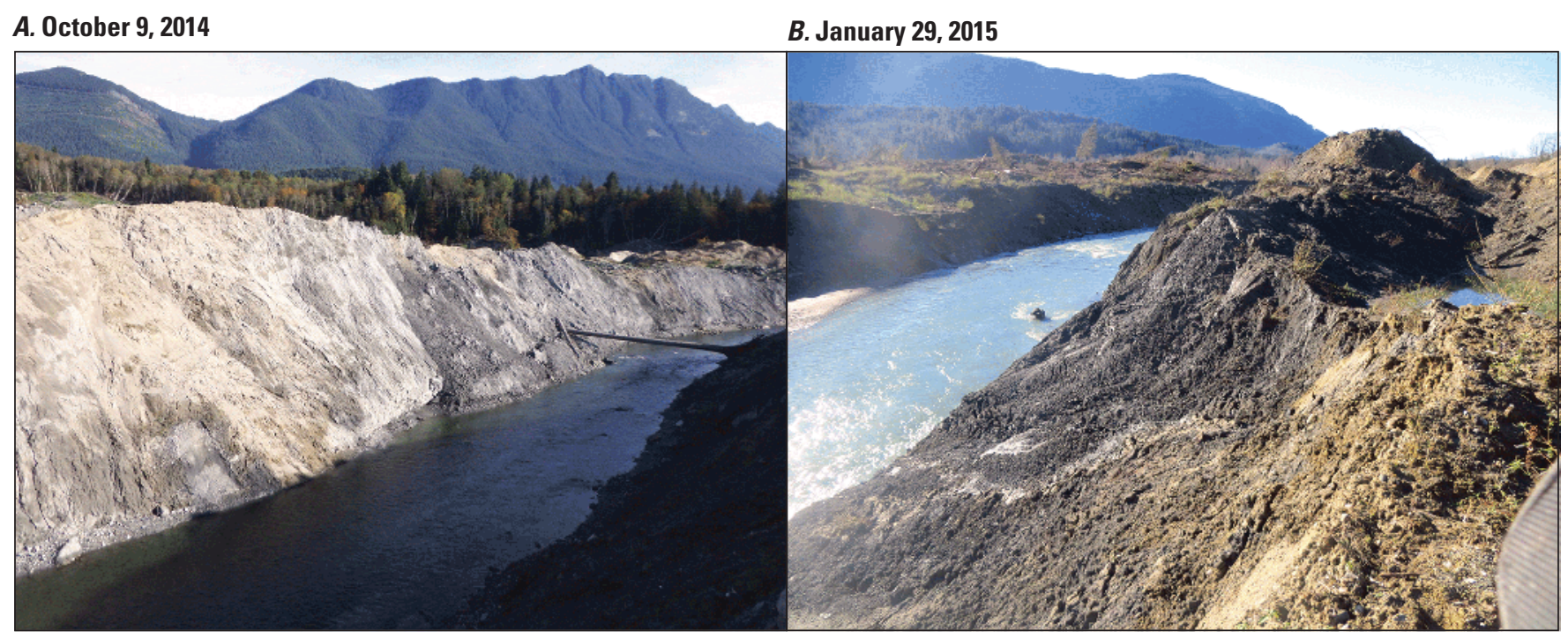

\section{January 6, 2015}

D. January 6, 2015
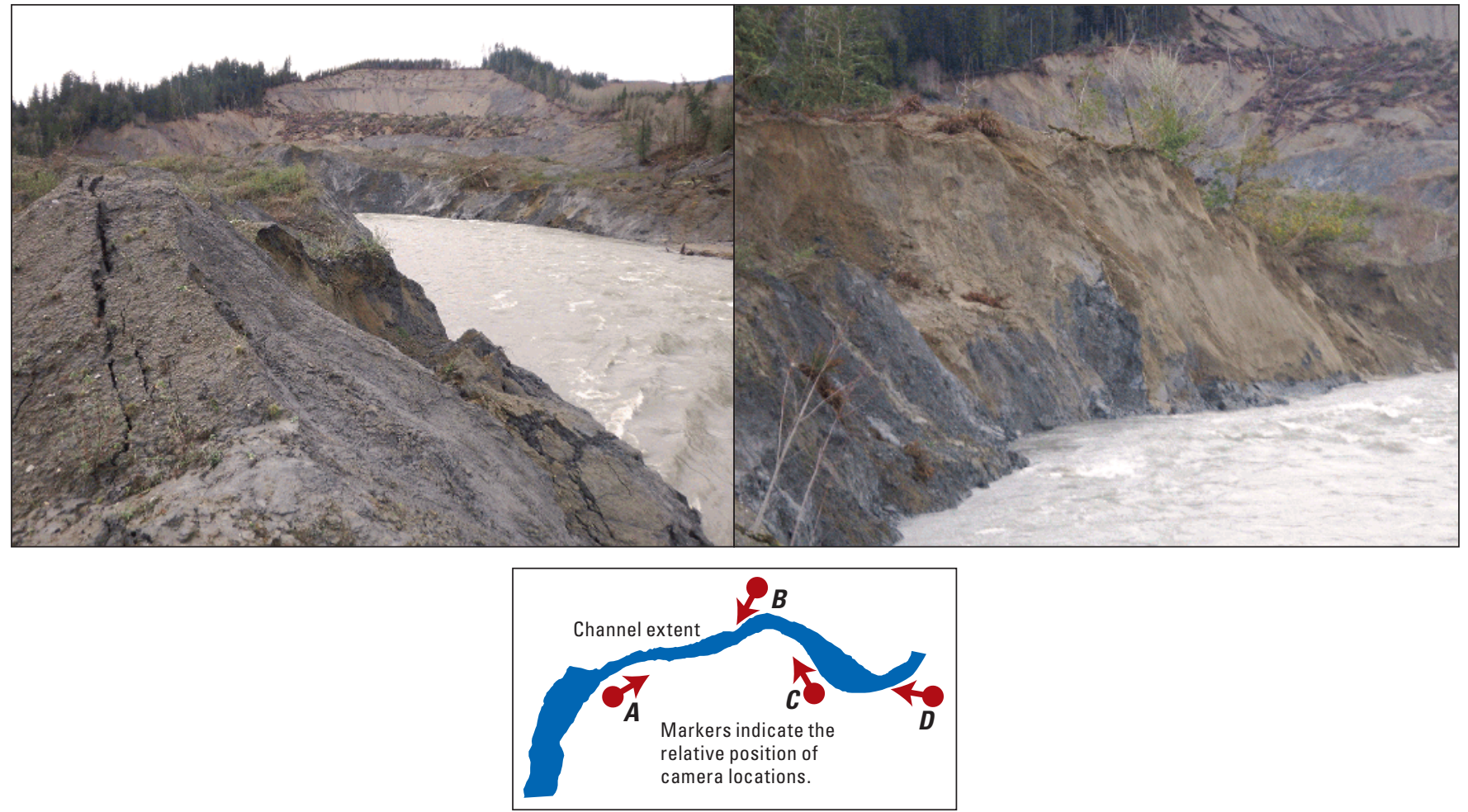

Figure 17. Typical bank conditions through the landslide deposit along North Fork Stillaguamish River, Washington, water year 2015. $(A)$ Lacustrine banks with shallow slumping, at the beginning of water year 2015. $(B)$ Lacustrine bank undergoing slow earth-flow style failure associated with surficial ponding. The brown material in foreground is sandy outwash. (C) Slumping of outwash material. (D) Steep banks of outwash material underlain by gray lacustrine material. Channel outline shown is as of July 7, 2015. Photographs by Scott W. Anderson, U.S. Geological Survey. 
Outwash material was composed of sand with some pebbles; median grain sizes were in the range of coarse sand (fig. 18). Field-measured bulk densities for outwash material averaged $1,240 \mathrm{~kg} / \mathrm{m}^{3}$ at the OW- 1 site and $1,440 \mathrm{~kg} / \mathrm{m}^{3}$ at the OW-3 site for an overall average of $1,340 \mathrm{~kg} / \mathrm{m}^{3}$ (Keith and others, 2017). Lacustrine samples were primarily composed of well-sorted silt and clay. Laboratory measured bulk densities for two samples were 1,670 and $1,740 \mathrm{~kg} / \mathrm{m}^{3}$, averaging $1,710 \mathrm{~kg} / \mathrm{m}^{3}$. Till was composed of poorly sorted material ranging from clay to cobbles. The till samples collected contained no material coarser than $128 \mathrm{~mm}$, but larger clasts, as much as $1 \mathrm{~m}$ in diameter, were observed within the unit in the field. Median grain sizes for till samples were in the range of coarse sand. No bulk density measurements were made of till. For estimating the total mass of the eroded sediment, a bulk density of $1,500 \mathrm{~kg} / \mathrm{m}^{3}$ was used for till, which is intermediate between the lacustrine and outwash samples.
Banks composed of the cohesive lacustrine material and those composed of the sandy outwash were consistently steep over the entire study period (figs. 13-14, 17). Erosion of lacustrine banks created near-vertical toe slopes up to the high-water line (fig. 17A, D). Above the high-water line, erosion occurred primarily through raveling or shallow slumping failures during flood events, but were stable at lower discharges. However, lacustrine banks that were saturated as a result of proximal surficial ponding would slump in slow earth flows during low-flow periods (fig. 17B). Banks composed of outwash material eroded primarily through continuous raveling, although evidence of occasional shallow slumping was found where the material was underlain by lacustrine material (figs. 17C and 17D).

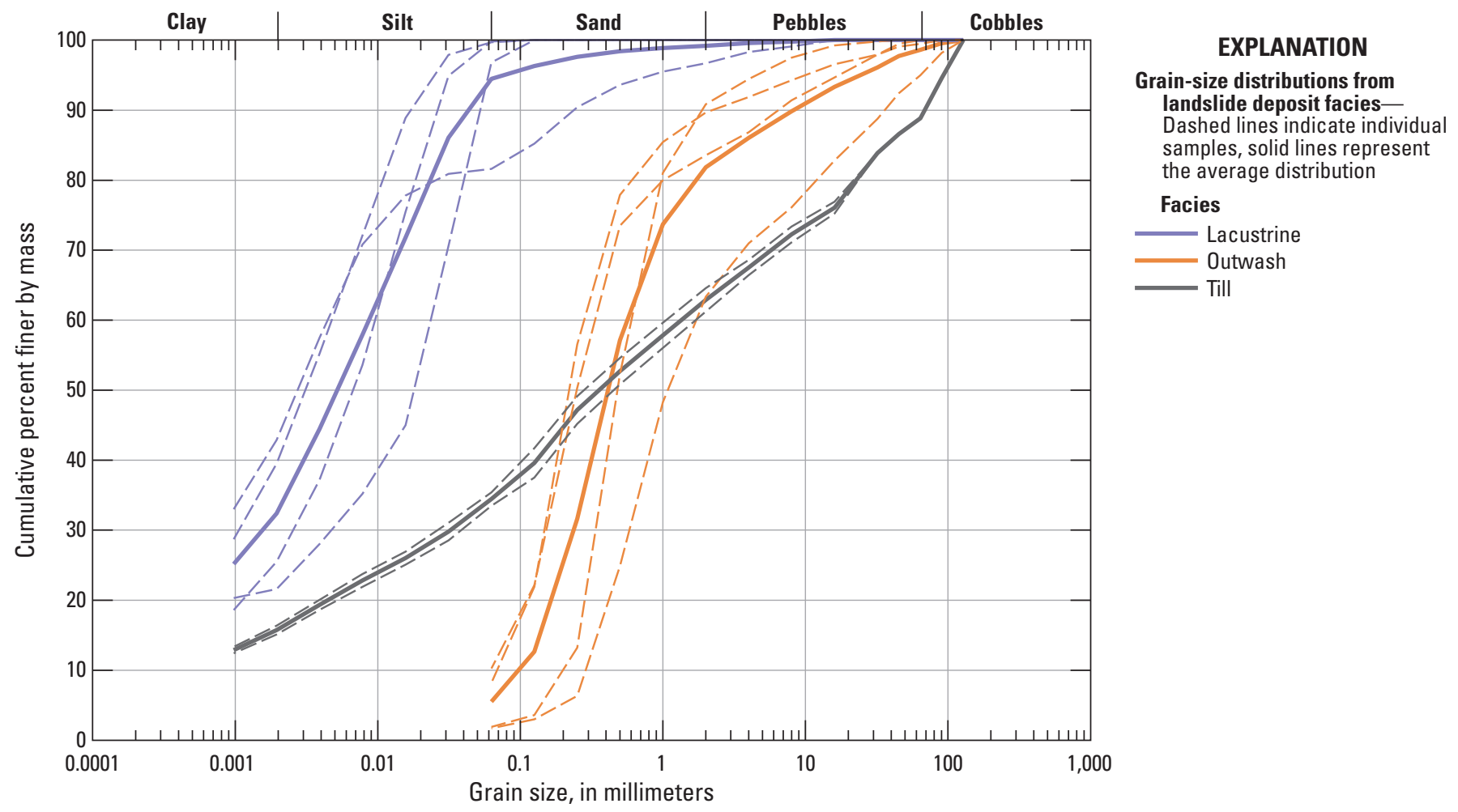

Figure 18. Grain-size distributions of landslide deposit facies from the SR 530 Landslide, North Fork Stillaguamish River, Washington. Outwash and till distributions combine fieldsieved measurements for material coarser than 4-8 millimeters (sample-dependent) with laboratory measurements for a split of the finer material. Lacustrine values are from laboratory measurements. 


\section{Sediment Delivery from the Landslide}

Differencing of repeat topographic surveys indicates that the North Fork Stillaguamish River eroded a total of $506,000 \pm 9,000 \mathrm{~m}^{3}$ of landslide deposit material during the 16-month period between March 24, 2014, and July 7, 2015 (table 7). Between March 24, 2014, and July 1, 2014, $257,000 \pm 7,000 \mathrm{~m}^{3}$ of this total was eroded, and the remaining 249,000 \pm 6,000 $\mathrm{m}^{3}$ eroded between July 1, 2014, and July 7, 2015. By volume, 76 percent of the total erosion was within areas mapped as fine-grained lacustrine material (table 7). Twenty-four percent of the eroded material was in areas mapped as sandy outwash; till units and mixed runout debris formed the remaining fraction of a percent of eroded material. Using the measured bulk densities to convert eroded volumes to mass, $820 \pm 80$ thousand metric tons of material was eroded from the deposit between March 24, 2014, and July 7, 2015 (fig. 19; table 7). More than 75 percent of the sediment entering the river was finer than $0.063 \mathrm{~mm}$, reflecting the prevalence of the fine-grained lacustrine material; 19 percent was sand (0.063-2 mm), and 4 percent was gravel (pebbles and cobbles; greater than $2 \mathrm{~mm}$ ).
Cumulative erosion over time was compared against the cumulative sum of the discharge through the landslide (fig. 20). Only discharge greater than $30 \mathrm{~m}^{3} / \mathrm{s}$ were counted in the cumulative sum because these low flows typically were not associated with any erosion. The slope of the resulting line then provides a measure of erosion efficiency. That slope monotonically decreased over the study period and appeared to asymptotically trend toward an unknown background erosion rate. Erosion efficiency was high in the first weeks after the landslide, but decreased by a factor of about four for the period after April 6, 2014. Efficiency remained relatively consistent through the late spring and summer 2014, and then began decreasing again at the onset of the 2014-15 flood season. Prior to July 1, 2014, the decreasing efficiency was likely a function of the decreasing channel gradient through the landslide reach (fig. 11). However, there was no substantial change in slope in WY 2015, and the continued decrease in efficiency over this period was likely a result of the reduction in flow depths and shear stresses associated with increasing channel width.

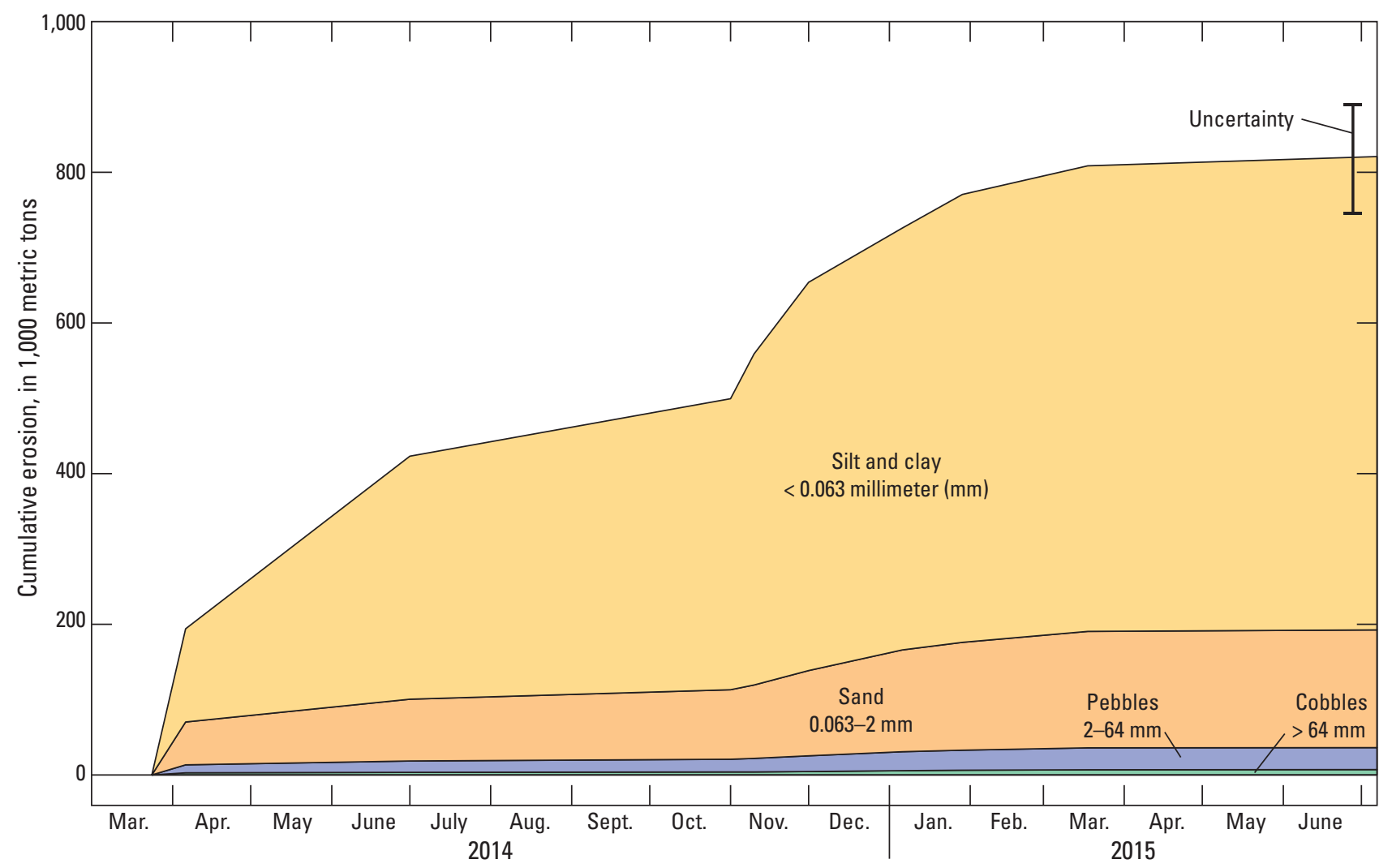

Figure 19. Cumulative mass of erosion and grain-size classes from the SR 530 Landslide deposit, North Fork Stillaguamish River, Washington. Uncertainty in the total mass of erosion, about \pm 10 percent, is from uncertainty in the total volume of erosion and the measured bulk densities. 


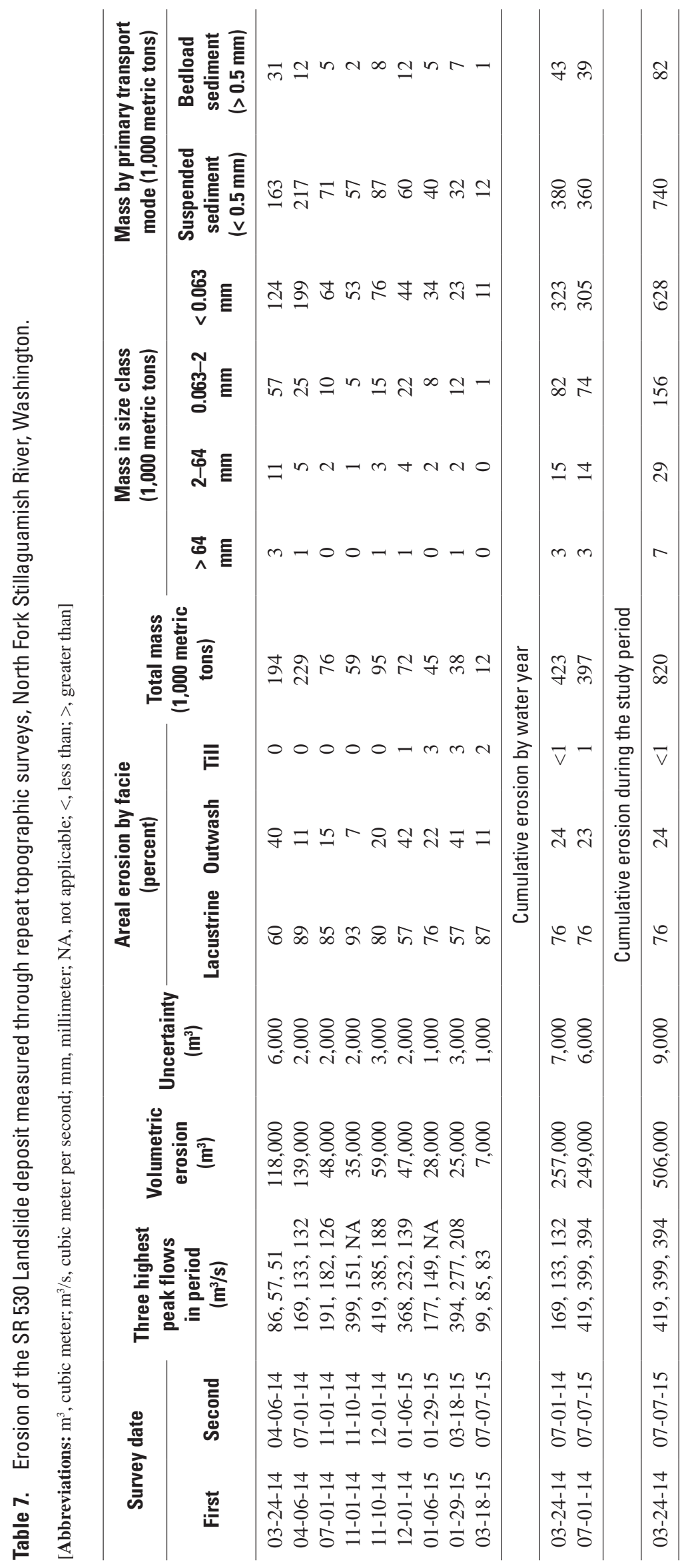



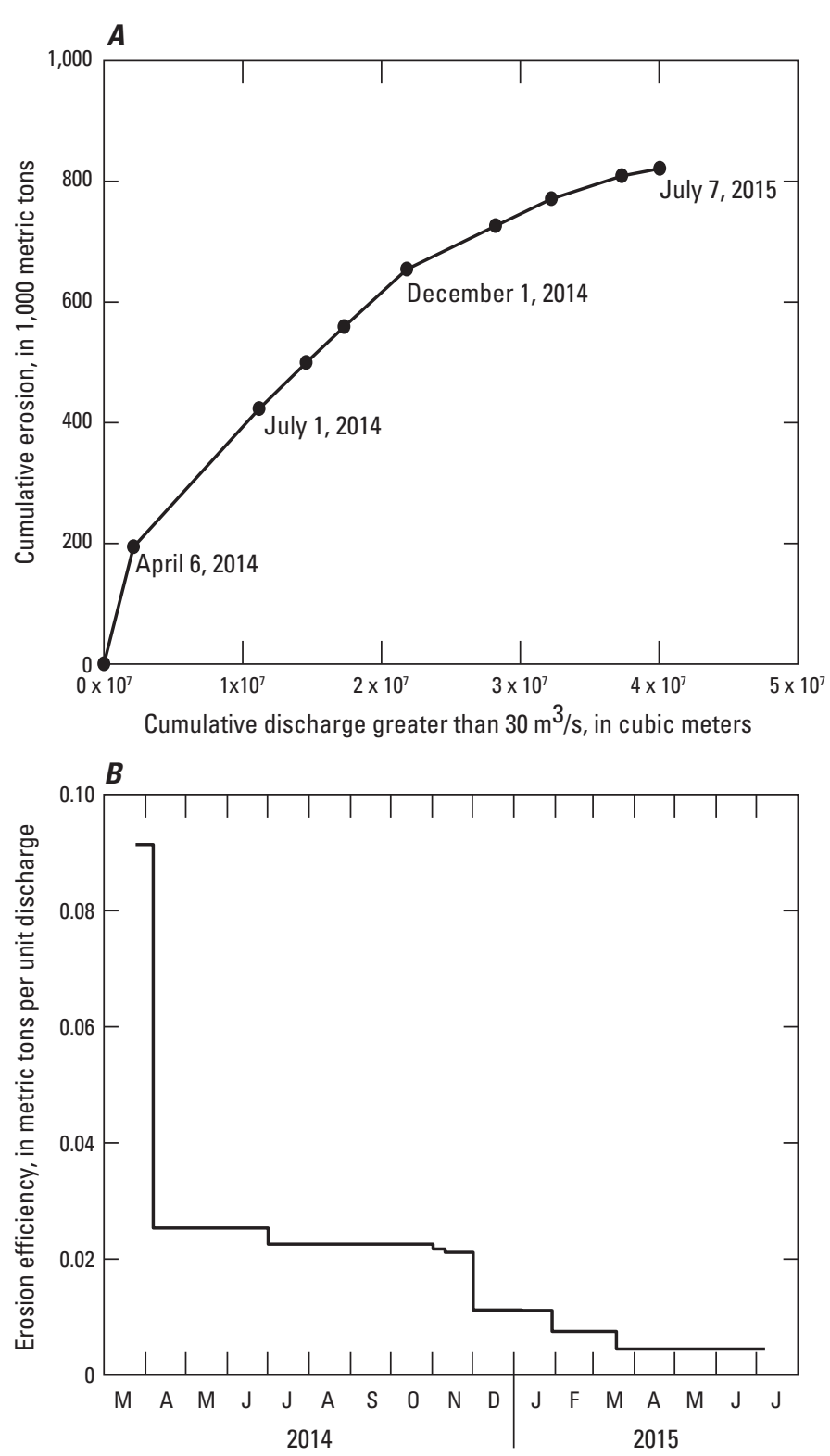

Figure 20. Cumulative erosion and erosion efficiency of the SR 530 Landslide deposit over time, North Fork Stillaguamish River, Washington. (A) Cumulative erosion compared with cumulative sum of discharge greater than 30 cubic meters per second $\left(\mathrm{m}^{3} / \mathrm{s}\right)$ from discharge record at Whitman (streamgage 12166300). Each point reflects a topographic survey. $(B)$ Mean erosion efficiency (slope in curve in $[A]$ between surveys) over time.

\section{Sediment Loads at Streamgages}

To assess the relative magnitudes of the landslide input and the ambient sediment load and better understand the downstream transport of landslide sediment, fluvial sediment loads were monitored at sites upstream and downstream of the landslide between March 2014 and September 2015. Continuous records of turbidity and periodic measurements of suspended-sediment concentrations allowed for estimated suspended sediment loads at two sites one site just upstream of the landslide and one site $5 \mathrm{~km}$ downstream of the landslide. Suspended-sediment loads on the main-stem Stillaguamish, near the mouth, also were available from November 2013 through September 2015 from the independent analysis of Anderson and others (2017). Bedload monitoring, most directly pertinent to understanding channel morphology changes, is more difficult and time-intensive than suspended sediment monitoring, and was done at only one site $5 \mathrm{~km}$ downstream of the landslide.

\section{Sediment Sampling and Load Estimation Methods}

\section{Suspended Sediment Measurements}

Discrete measurements of suspended-sediment concentration (SSC) were collected at Whitman Road Bridge, co-located with the Whitman streamgage (USGS streamgage 12166300) downstream of the landslide, and at C-Post bridge, upstream of the landslide and approximately co-located with the Swede Heaven streamgage (USGS streamgage 12166300) (fig. 2). Discrete measurements of SSC were collected using the equal-width-increment (EWI) or equal-dischargeincrement (EDI) method to ensure samples were representative of the cross section (Edwards and Glysson, 1999). Samples were collected using various Federal Interagency Sediment Project-approved depth-integrated samplers (Davis, 2006). Sediment samples were analyzed at the USGS sediment laboratory at the Cascades Volcano Observatory for total sediment concentration and the percentage of material finer than $0.063 \mathrm{~mm}$ by mass (referred to as fines or fine SSC) to aid in the identification of any systematic variations in the grain size of the suspended-sediment load. A subset of samples also were analyzed for full grain-size distributions and in conjunction with grain-size distributions of concurrent bedload samples were used to determine the most likely mode of transport (in suspension or as bedload) for particles of a given size. 


\section{Bedload Measurements}

Bedload samples were collected at Whitman Road Bridge, co-located with the streamgage at Whitman. Sampling procedures followed the multiple equal-widthincrement method described in Edwards and Glysson (1999). Samples were collected with an Elwha sampler (10.1 × $20.3 \mathrm{~cm}$ opening, 1.4 expansion ratio; fig. 21A) or TR-2 sampler $(15.2 \times 30.5 \mathrm{~cm}$ opening, 1.4 expansion ratio; fig. 21B) operated from a truck-mounted boom. All bedload samples were analyzed at the Cascades Volcano Observatory Sediment Laboratory for grain size and mass. Each bedload sample was composed of more than 40 individual verticals, all of which were composited for grain-size analysis. A transport rate for each measurement was calculated following guidance in Edwards and Glysson (1999), using the formula

$$
Q_{b}=\frac{M \times\left[\frac{W}{n \times w}\right]}{T}
$$

where

$\mathrm{Q}_{\mathrm{b}} \quad$ is the bedload transport rate, in kilograms per second;

M is the total sample mass, in kilograms;

$\mathrm{T}$ is the sample time per vertical, in seconds;

W is the wetted width of the channel, in meters;

$\mathrm{n} \quad$ is the number of verticals (unitless); and

w is the width of the sampler, in meters.

\section{Sediment Loads and Uncertainty Estimates}

Sediment loads over the period of study were estimated using sediment rating curves developed through linear regression between measured sediment loads and concurrent values of continuously monitored quantities from co-located streamgages. Measured bedload transport rates were regressed against the discharge at the time of sampling, and the resulting relation was used to translate the continuous discharge record into a continuous estimate of bedload transport. Measured SSC was regressed against concurrent values of turbidity (Wagner and others, 2006; Anderson and others, 2010), and the rating curve used to estimate continuous SSC (Rasmussen and others, 2009). These concentrations were then converted to suspended-sediment loads using the available discharge records. This process was applied to the total SSC and the fine fraction of SSC $(<0.063 \mathrm{~mm})$ to estimate the relative contributions of fine (silt and clay) and coarse (sand) suspended material to the total suspended-sediment load.

Uncertainty in the sediment load estimates were quantified based on statistical uncertainty in the regressions that form the rating curves (Cohn and others, 1989; Gilroy and others, 1990; Cohn, 2005). Estimates of bedload transport were based on log-transformed variables, introducing transformation bias when re-transformed back to real space. The USGS Rloadest package (Lorenz and others, 2015), which implements the adjusted maximum likelihood estimator method of Cohn (2005) was used to provide confidence intervals around summed estimates of bedload that properly accounts for this transformation bias.
$\boldsymbol{A}$

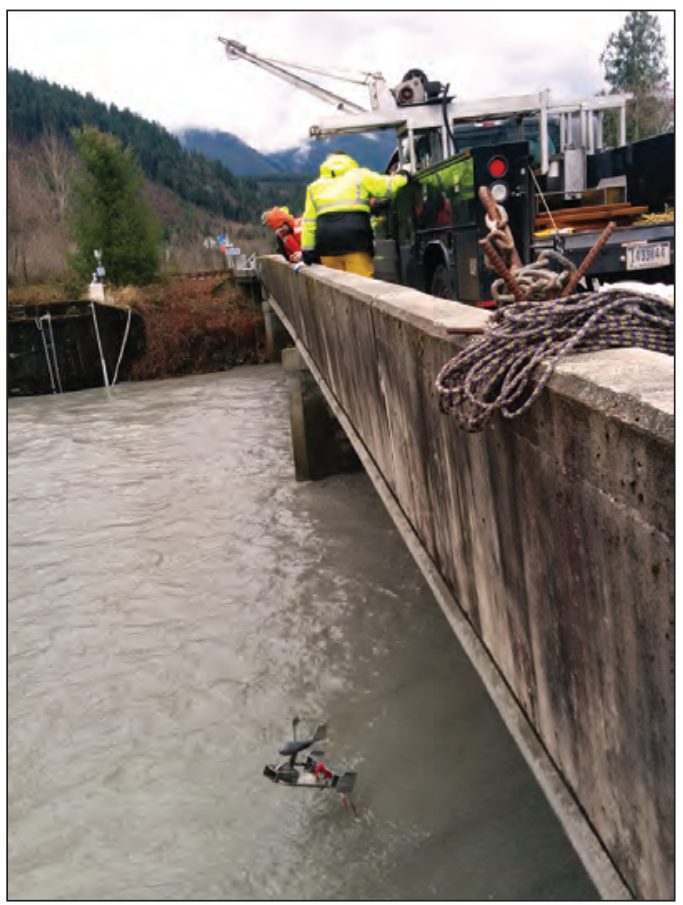

B

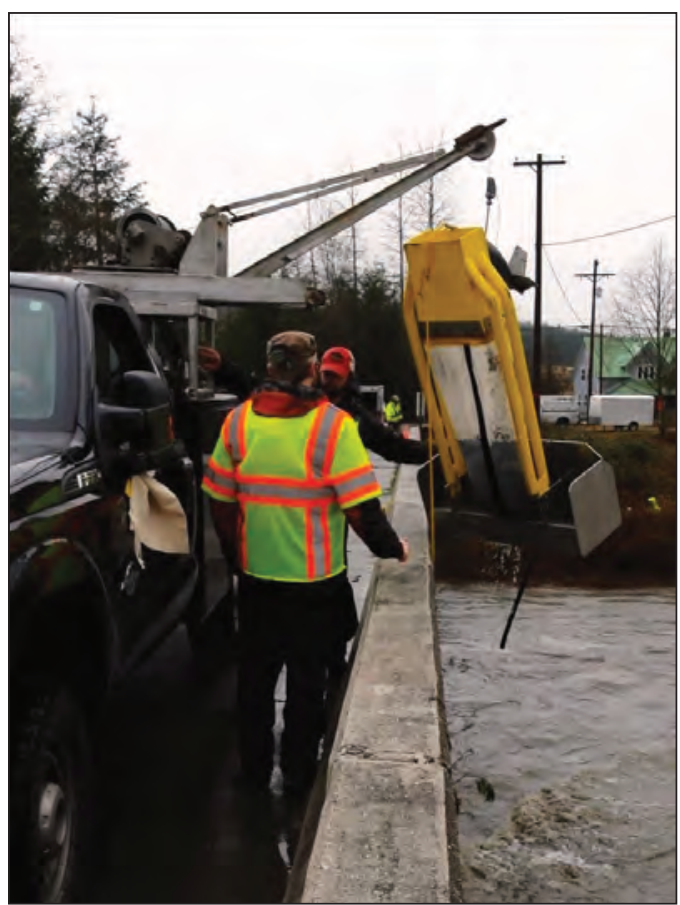

Figure 21. Bedload sampling using $(A)$ an Elwha bedload sampler and $(B)$ a TR-2 bedload sampler at Whitman Road bridge, North Fork Stillaguamish River near Oso, Washington. 
All regressions between turbidity and SSC were done on untransformed variables, and so transformation bias was not an issue. Uncertainty in load estimates as result of the regression then could be calculated as the variance of summed correlated variables,

$$
\operatorname{Var}\left(\sum_{i=1}^{n} C_{i}\right)=\sum_{i=1}^{n} \operatorname{Var}\left(C_{i}\right)+\sum_{i=l}^{n} \sum_{j \neq i}^{n} \operatorname{Cov}\left(C_{i}, C_{j}\right)
$$

where $C_{i}$ is the concentration at one of the $n$ time stamps in the full period of record and the variance and covariance terms are defined by the variance-covariance matrix (VCV) of the regression coefficients and calculated as

$$
\operatorname{Var}\left(C_{i}\right)=\boldsymbol{X}_{\boldsymbol{i}} \boldsymbol{V C V} \boldsymbol{X}_{\boldsymbol{i}}^{\prime}
$$

and

$$
\operatorname{Cov}\left(C_{i}, C_{j}\right)=\boldsymbol{X}_{i} \boldsymbol{V C V} \boldsymbol{X}_{j}^{\prime}
$$

where $\mathbf{X}_{\mathbf{i}}$ and $\mathbf{X}_{\mathrm{j}}$ are vectors representing the ith and $\mathrm{jth}$ set of predictor variables for which measured loads or concentrations are unavailable (Gilroy and others, 1990).

These uncertainties assume that measurements are accurate, so that variability about the mean relation predominantly reflects real and natural variations in transport for a given surrogate value, and that the fundamental form of the regression is correctly specified (Gilroy and others, 1990). For turbidity-SSC relations, these assumptions are likely reasonable; however, for bedload, these assumptions are somewhat optimistic, and the associated uncertainties may underestimate the true uncertainty around integrated load estimates.

\section{Fraction of Landslide Sediment in Stanwood Suspended-Sediment Load}

Continuous records of discharge and turbidity at the mouth of the Stanwood streamgage (fig. 1), were available between November 15, 2013, and September 30, 2015, encompassing a 4-month period prior to the landslide and the full period of this study. Anderson and others (2017) used these data, in combination with discrete measurements of SSC, to estimate suspended-sediment loads using methods similar to those described here. A sharp and sustained increase in turbidity beginning on March 24, 2014, indicated that some amount of landslide sediment reached the mouth of the Stillaguamish River in a relatively short timeframe (fig. 22). In order to estimate how much of the calculated suspended-sediment load at Stanwood could be attributed to the landslide, estimates of suspended-sediment load based on discharge, which were not altered by the landslide, were compared against estimates of suspended-sediment load based on turbidity, which the landslide did increase substantially.

The difference between these estimates was then interpreted as a measure of the mass of suspended-sediment directly attributable to the landslide.

The pre-landslide relation between discharge and suspended-sediment loads was defined based on the turbidity-based load estimates over the 4 months before the landslide (fig. 23). The relation between daily mean discharge and daily suspended-sediment load over this period was well characterized by a power-law regression. For each day after the landslide, the mass of landslide sediment present in the daily sediment load was estimated as the difference between the turbidity-based estimate from Anderson and others (2017) and the discharge regression shown in figure 23 . These daily estimates then were summed to provide a cumulative estimate of the mass of landslide sediment passing Stanwood in suspension. Because all observations of daily loads, including those used to form the discharge-load regression prior to the landslide and those used after the landslide, are derived from the same turbidity-SSC relation presented in Anderson and others (2017), estimates of the landslide mass traveling in suspension are relatively robust against errors in that underlying relation. 


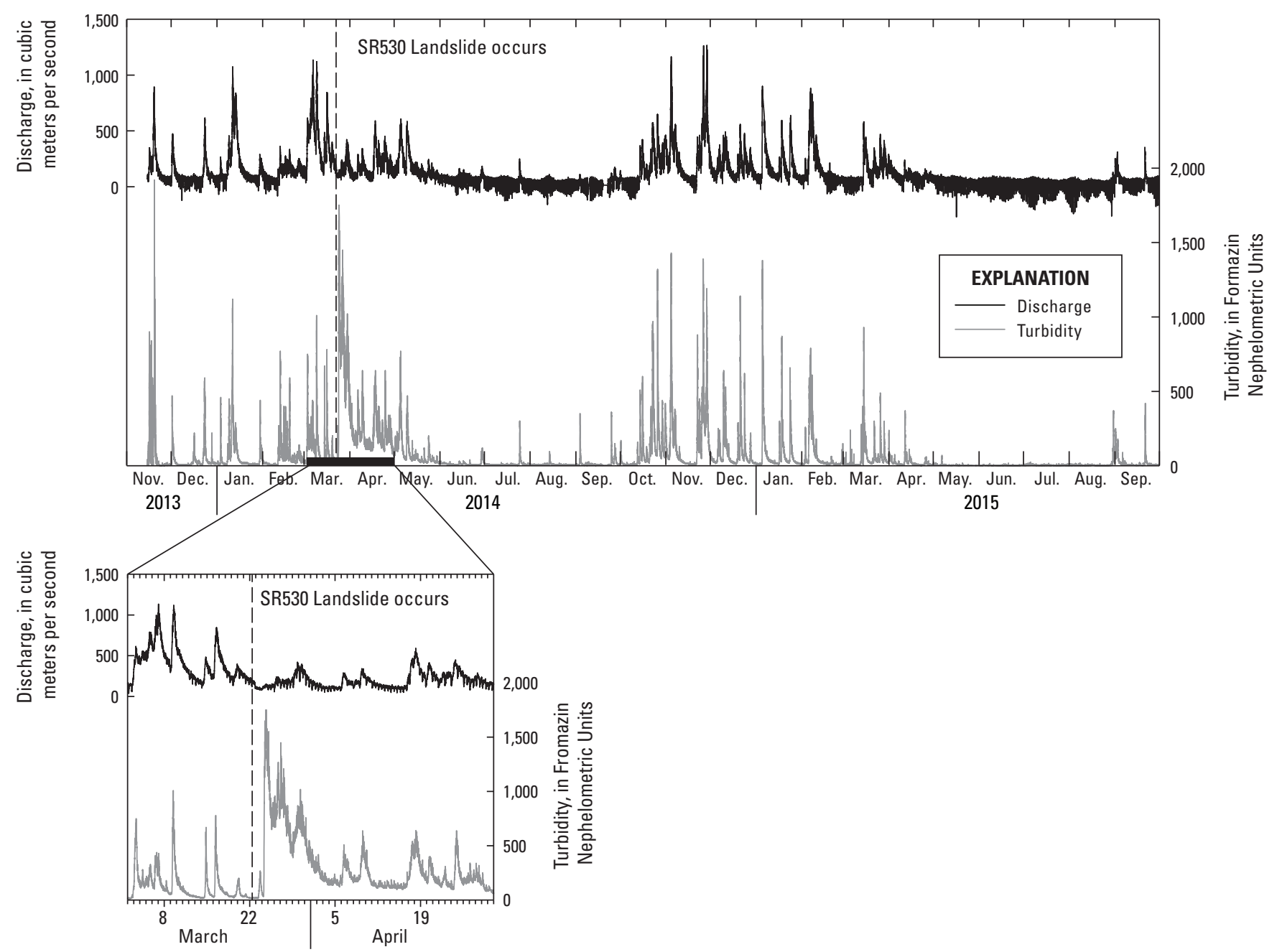

Figure 22. Discharge and turbidity at the mouth of the main-stem Stillaguamish River near Stanwood Washington (USGS streamgage 12170300), November 2013-September 2015. 


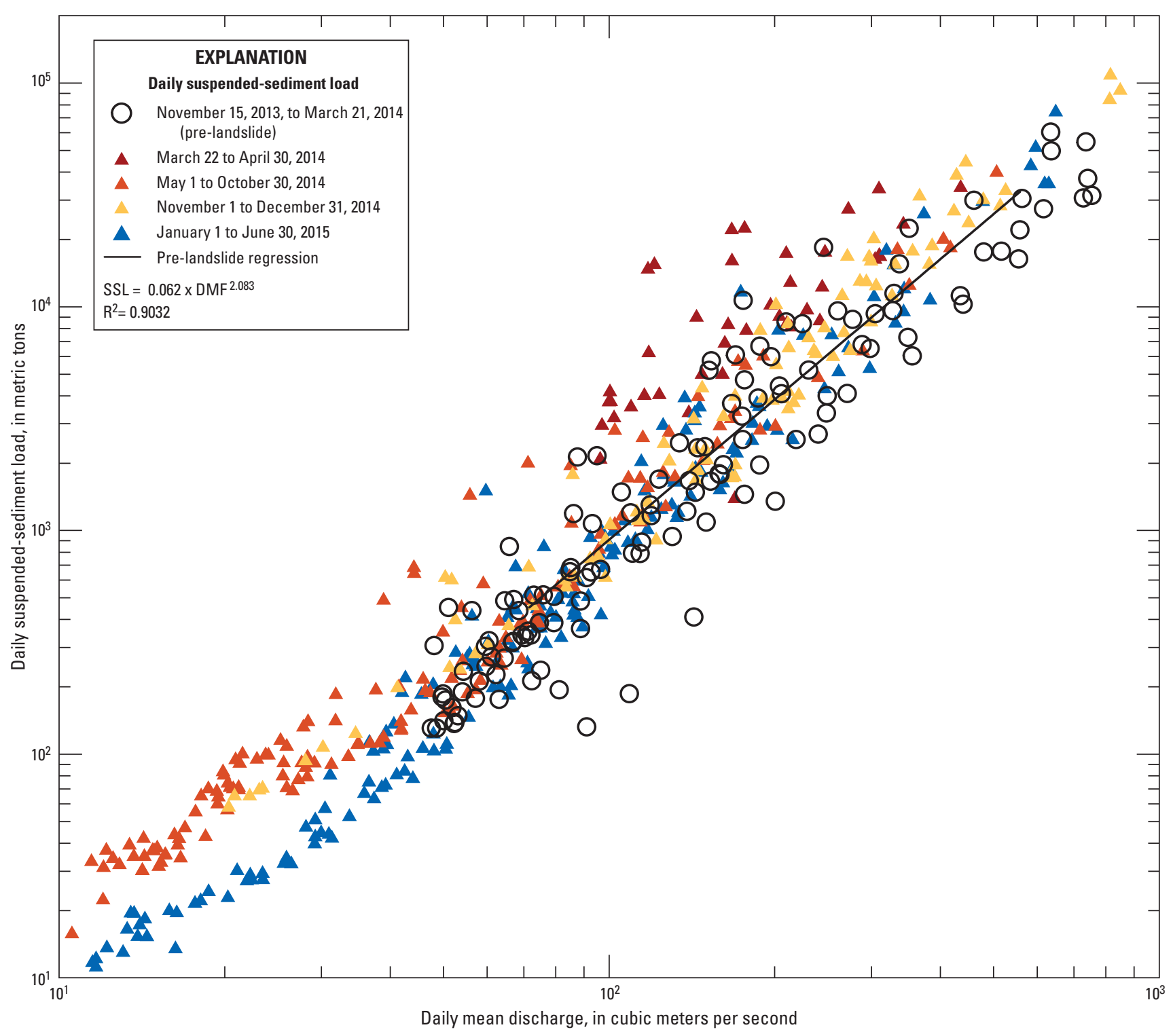

Figure 23. Daily suspended-sediment load and daily mean discharge at Stillaguamish River near Stanwood, Washington (USGS streamgage 12170300). Daily data have been subdivided into the pre-landslide period and several post-landslide periods. The sediment contribution of the landslide on a given day was estimated as the difference between the estimate of Anderson and others (2017) and the power-law regression fit to the pre-landslide data, under the assumption that any systematic shift was the result of increased sediment sourced from the SR 530 Landslide.

\section{Sediment Loads at Streamgages}

\section{Swede Heaven}

Six measurements of SSC were made at C-Post Bridge, and ranged from 38 to $564 \mathrm{mg} / \mathrm{L}$ (table 8). The fraction of material finer than $0.063 \mathrm{~mm}$ in these samples ranged from 43 to 67 percent, with an average 60 percent. Turbidity at Swede Heaven was monitored using a DTS-12 turbidity meter, installed on March 28, 2014. Stage and discharge records began on the same day. All records were essentially continuous between monitor installation and the end of analysis on September 30, 2015 (fig. 24). Minor gaps in the record occurred only during periods of low flow and low turbidity, and were filled using linear interpolation. The relation between turbidity and total and fine SSC were well fit by linear regression, although the lack of high-turbidity samples leaves the higher end of the rating curves poorly constrained, and results in large uncertainties around the estimates of suspended-sediment loads (fig. 25). 
Table 8. Suspended-sediment concentrations at North Fork Stillaguamish River near Swede Heaven, Washington (USGS streamgage 12166185).

[Method: EDI, equal-discharge-increment; EWI, equal-width-increment. SSC: Suspended-sediment concentration. Abbreviations. FNU, Formazin Nephelometric Unit; $\mathrm{m}^{3} / \mathrm{s}$, cubic meter per second; $\mathrm{mg} / \mathrm{L}$, milligram per liter; mm, millimeter; NA, not applicable]

\begin{tabular}{cccccccc}
\hline Date & Start time & End time & Method & $\begin{array}{c}\text { Discharge } \\
(\mathbf{m} \mathbf{3} / \mathbf{s})\end{array}$ & $\begin{array}{c}\text { Turbidity } \\
\text { (FNU) }\end{array}$ & $\begin{array}{c}\text { SSC } \\
(\mathbf{m g} / \mathbf{L})\end{array}$ & $\begin{array}{c}\text { Percent } \\
\text { Fine SSC } \\
(<\mathbf{0 . 0 6 3} \mathbf{~ m m})\end{array}$ \\
\hline $04-17-14$ & 1439 & 1537 & EWI & 57.4 & 20 & 38 & NA \\
$10-23-14$ & 1215 & 1228 & EDI & 96.6 & 36 & 82 & 64 \\
$12-09-14$ & 1410 & 1421 & EDI & 111 & 120 & 210 & 63 \\
$12-10-14$ & 1130 & 1144 & EDI & 70.5 & 35 & 165 & 65 \\
$02-05-15$ & 1650 & 1745 & EWI & 98.8 & 103 & 270 & 67 \\
$02-06-15$ & 1132 & 1220 & EWI & 240 & 170 & 564 & 43 \\
\hline
\end{tabular}

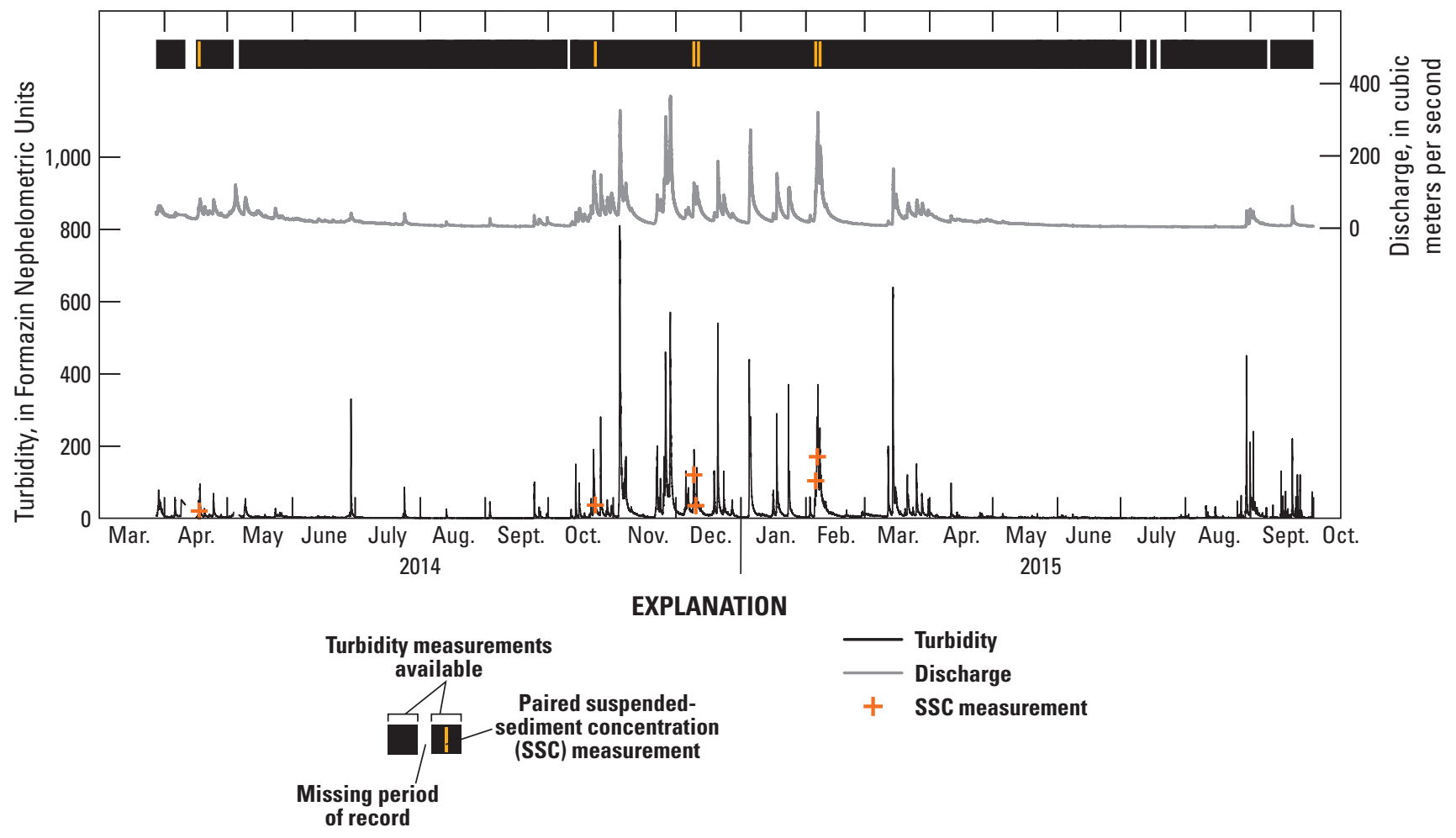

Figure 24. Turbidity, discharge and suspended-sediment concentrations at North Fork Stillaguamish near Swede Heaven, Washington (USGS streamgage 12166150). Timing of suspended-sediment concentration measurements are plotted as the mean turbidity value during the measurement. 

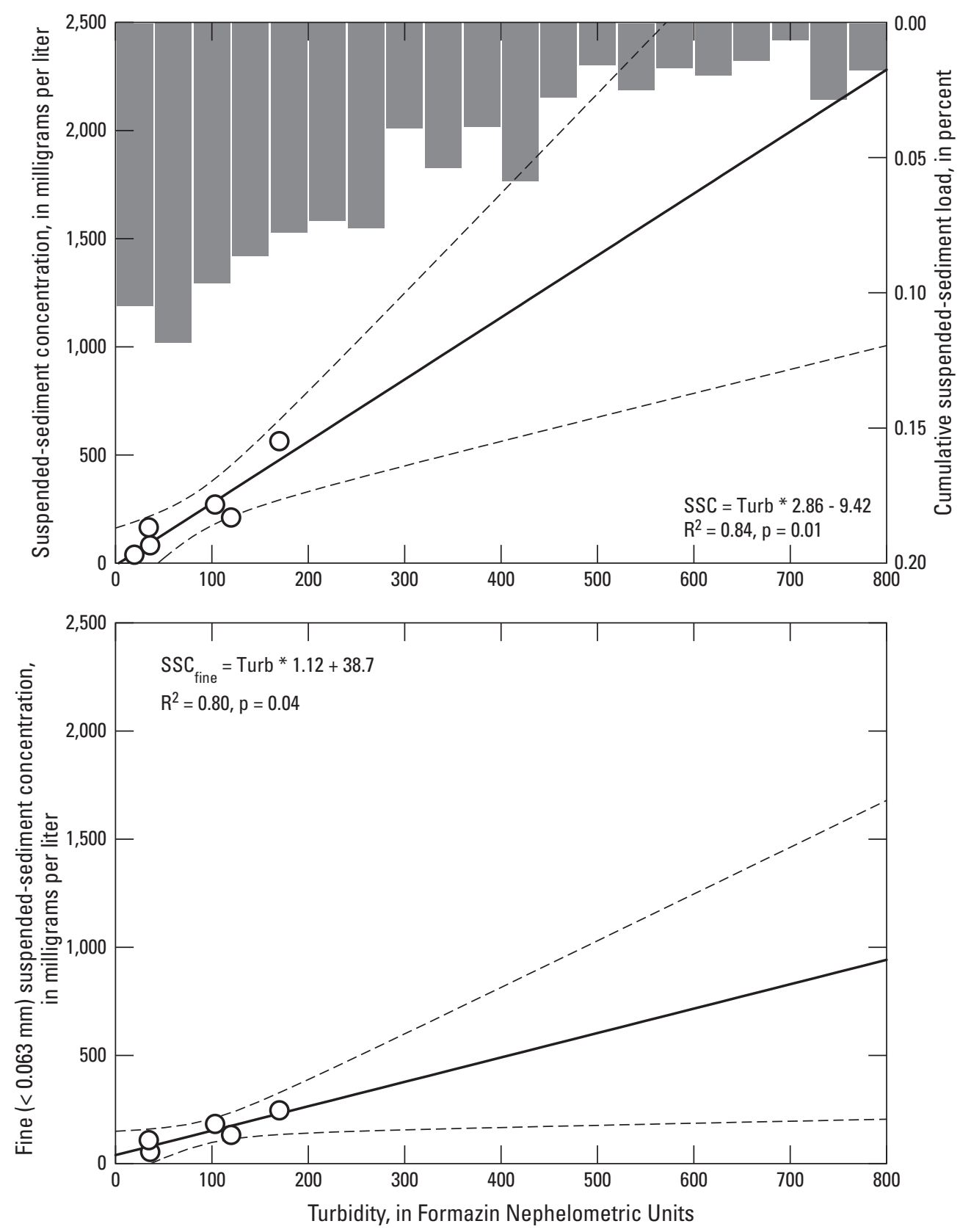

EXPLANATION

Percentage of suspended-sediment load transported in given turbidity range

Linear regression

95-percent prediction interval

O Suspended-sediment concentration (SSC) measurement

Figure 25. Regressions between turbidity and $(A)$ suspended-sediment concentration and $(B)$ suspended-sediment finer than 0.063 millimeter (mm) at North Fork Stillaguamish near Swede Heaven, Washington (USGS streamgage 12166150).

Regressions and uncertainty bounds are extrapolated to 800 Formazin Nephelometric Units (FNUs), the peak turbidity over the period of analysis. Histogram in $(A)$ shows what fraction of the total suspended-sediment load over the study interval was transported during periods of various turbidities. 
Applying the developed suspended sediment rating curve to the turbidity record over WY 2014-LS, the estimated suspended-sediment load at Swede Heaven was $7 \pm 60$ thousand metric tons, indistinguishable from zero (table 9). During WY 2015, the total suspended-sediment load at Swede Heaven was $150 \pm 90$ thousand metric tons, of which $100 \pm 55$ thousand metric tons (about 65 percent) was material finer than $0.063 \mathrm{~mm}$ (fig. 26).

Table 9. Estimated sediment loads at selected streamgage sites, North Fork Stillaguamish River, Washington.

[Abbreviations km², square kilometer; mm, millimeter; NA, not applicable; USGS, U.S. Geological Survey; WY, water year; -, no data]

\begin{tabular}{|c|c|c|c|c|c|c|c|c|c|}
\hline \multicolumn{3}{|c|}{ Study period } & \multicolumn{4}{|c|}{ Sediment load (1,000 metric tons) } & \multicolumn{3}{|c|}{ Yield (metric tons $/ \mathbf{k m}^{2}$ ) } \\
\hline Period & Start & End & $\begin{array}{l}\text { Suspended } \\
\text { sediment }\end{array}$ & $\begin{array}{c}\text { Fine } \\
\text { suspended } \\
\text { sediment }\end{array}$ & $\begin{array}{l}\text { Bed } \\
\text { load }\end{array}$ & $\begin{array}{l}\text { Total } \\
\text { load }\end{array}$ & $\begin{array}{l}\text { Suspended } \\
\text { sediment }\end{array}$ & $\begin{array}{l}\text { Bed } \\
\text { load }\end{array}$ & Total \\
\hline \multicolumn{10}{|c|}{ North Fork Stillaguamish River near Swede Heaven (USGS streamgage 12166150; “Swede Heaven”) } \\
\hline WY 2014-LS & 03-28-14 & 09-30-14 & $7 \pm 60$ & ${ }^{1} 20 \pm 40$ & - & - & 18 & - & - \\
\hline WY 2015 & $10-01-14$ & 09-30-15 & $150 \pm 90$ & $100 \pm 55$ & - & - & 420 & - & - \\
\hline Entire study & 03-28-14 & 09-30-15 & $160 \pm 150$ & $120 \pm 90$ & - & - & 439 & - & - \\
\hline \multicolumn{10}{|c|}{ North Fork Stillaguamish River near Oso (USGS streamgage 12166300; “Whitman”) } \\
\hline WY 2014-LS & $03-26-14$ & 09-30-14 & $430 \pm 40$ & $300 \pm 25$ & $65 \pm 15$ & $500 \pm 70$ & 1,030 & 170 & 1,200 \\
\hline WY 2015 & $10-01-14$ & 09-30-15 & $560 \pm 70$ & $380 \pm 45$ & $245 \pm 40$ & $800 \pm 80$ & 1,350 & 580 & 1,930 \\
\hline Entire study & 03-26-14 & 09-30-15 & $990 \pm 110$ & $680 \pm 70$ & $310 \pm 65$ & $1,300 \pm 130$ & 2,380 & 740 & 3,120 \\
\hline \multicolumn{10}{|c|}{ Stillaguamish River near Stanwood (USGS streamgage 12170300; “Stanwood”) } \\
\hline Pre-landslide & $11-15-13$ & $03-21-14$ & $660 \pm 100$ & $400 \pm 35$ & - & - & 390 & - & - \\
\hline WY 2014-LS & $03-22-14$ & $09-30-14$ & $570 \pm 90$ & $370 \pm 30$ & - & - & 330 & - & - \\
\hline WY 2015 & $10-01-14$ & 09-30-15 & $1,400 \pm 170$ & $870 \pm 55$ & - & - & 810 & & \\
\hline Entire study & $03-22-14$ & 09-30-15 & $1,970 \pm 400$ & $1,240 \pm 120$ & - & - & 1,140 & - & - \\
\hline
\end{tabular}

${ }^{1}$ Fine suspended-sediment load exceeding the full suspended-sediment load is an artifact of the regressions used to estimate the loads. 
USGS streamgage 12166185, North Fork Stillaguamish near Swede Heaven (Swede Heaven)

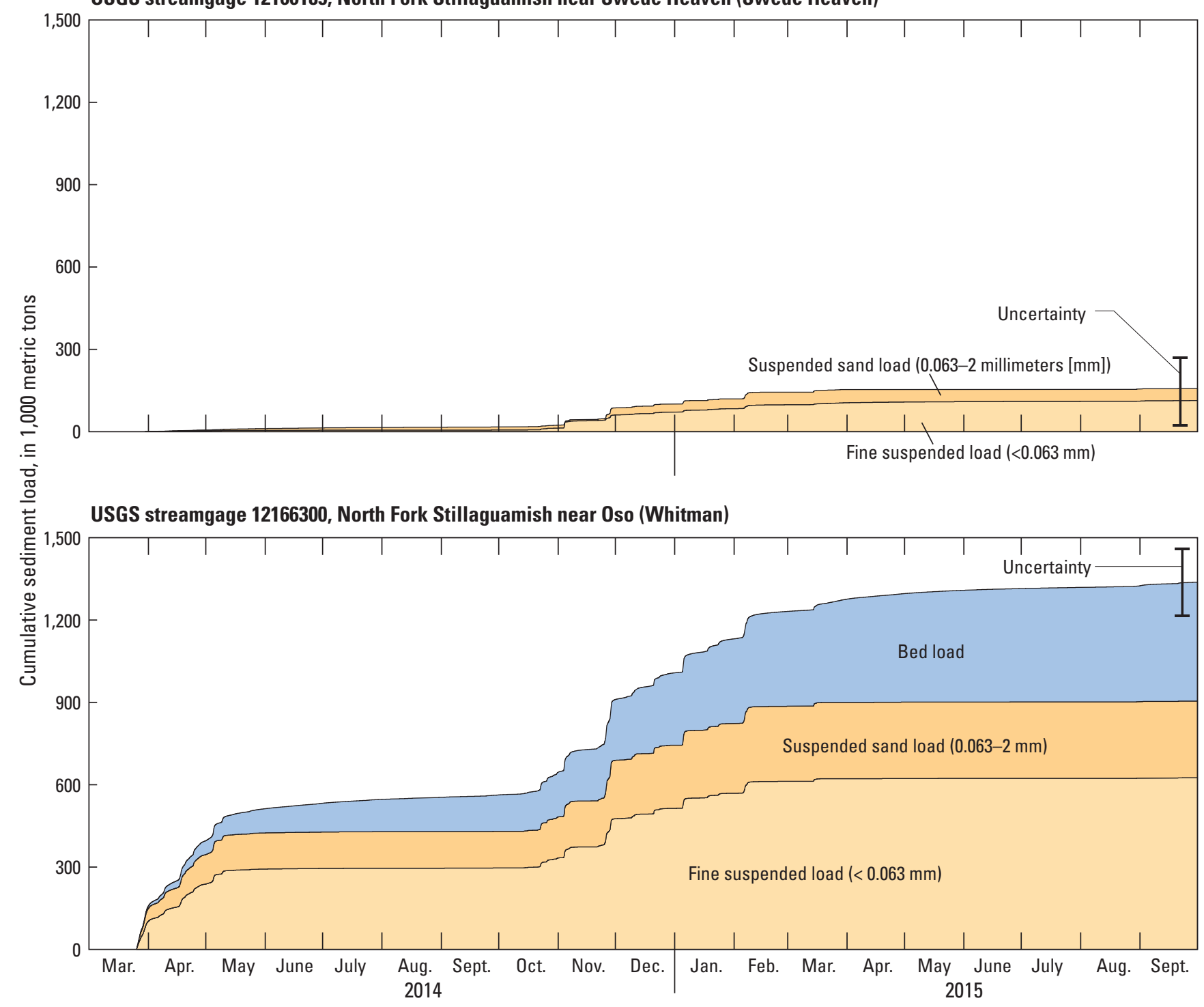

Figure 26. Cumulative sediment transport at Swede Heaven (USGS streamgage 12166185), upstream of the landslide, and Whitman (USGS streamgage 12166300), downstream of the landslide, North Fork Stillaguamish River near Oso, Washington. No bedload measurements or estimates of bedload transport were made at Swede Heaven. Uncertainties are in the total suspended-sediment load at Swede Heaven and combined bedload and suspended-sediment load at Whitman. 


\section{Whitman}

\section{Suspended-Sediment Load}

Twenty-four SSC measurements were made at the Whitman site, most of which were collected in the weeks immediately following the landslide (fig. 27; table 10). Measured concentrations ranged from 570 to $5,594 \mathrm{mg} / \mathrm{L}$. The percentage of fine material (diameters less than $0.063 \mathrm{~mm}$ ) in measurements, excluding one sand-rich outlier collected on April 7, 2014, varied between 47 and 79 percent, with a mean of 67 percent (table 10). No relation between the percentage of fines and discharge was apparent, and the percentage of fine material did not vary systematically over time.

Turbidity was monitored at the Whitman streamgage using three turbidity sensors operated over distinct but overlapping periods (fig. 27). The timing of SSC measurements and several extended periods of turbidity sensor malfunctions prevented the calculation of robust and continuous SSC estimates from each sensor independently (with one exception; see section, “Turbidity Sensor

Regressions at Whitman” in appendix A), and because each sensor is calibrated differently, the records cannot be directly spliced together. Instead, the strong correlations between overlapping periods of record were used to develop regressions between the various sensors. These regressions allowed records from one sensor to be translated to the effective units of another, providing a nearly continuous turbidity record over the study period with consistent effective calibration and therefore a consistent relation to measured SSC. Additional information regarding the regressions is presented in appendix A. After creating the continuous turbidity record, there remained several periods where no reliable turbidity data were available. These periods all occurred during summer low-flow conditions and were filled in using linear interpolation between records immediately before and after the gaps.

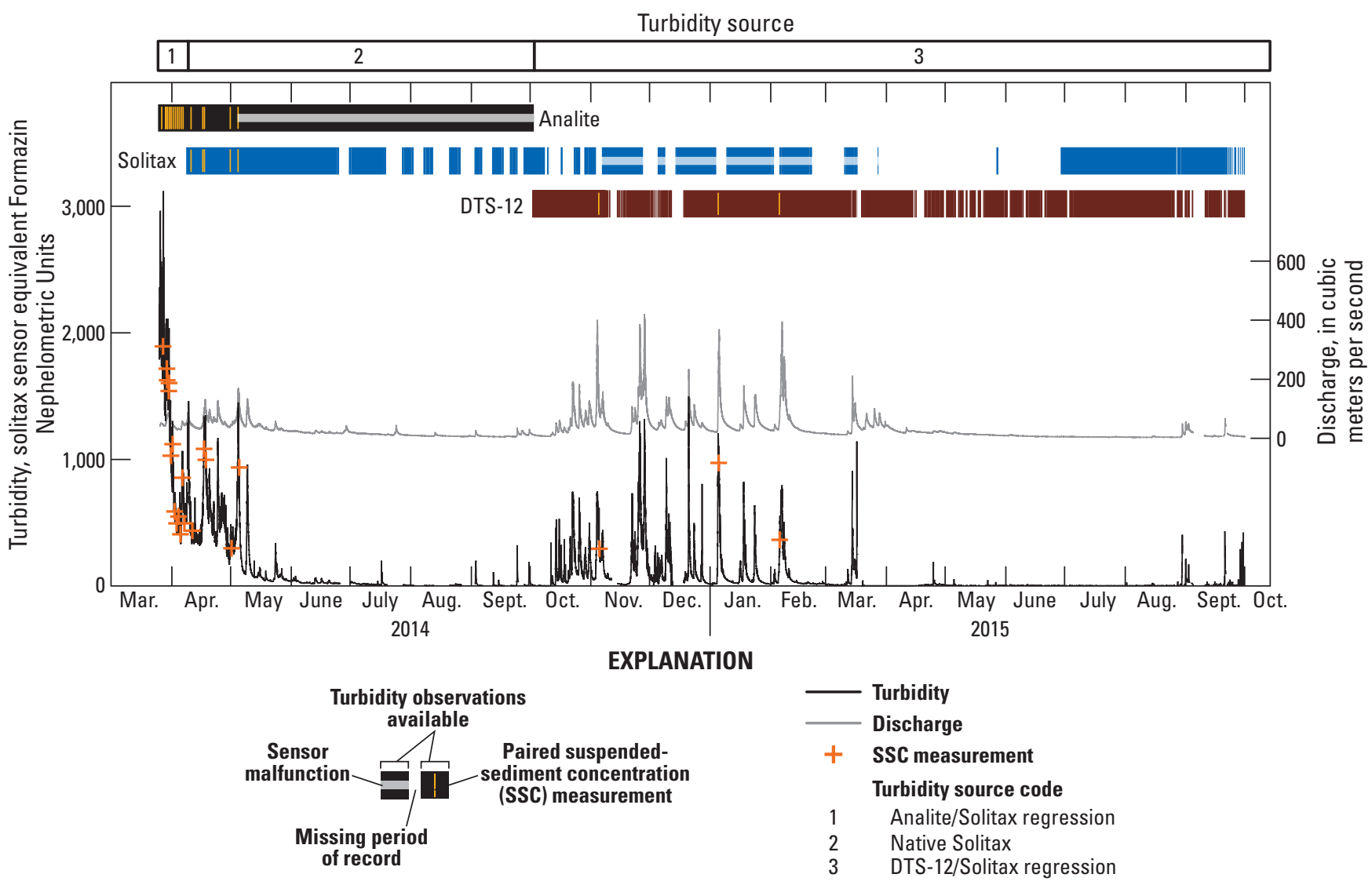

Figure 27. Turbidity, discharge, and suspended-sediment concentrations at North Fork Stillaguamish near Oso (Whitman), Washington (USGS streamgage 12166300). Periods of operation and turbidity sensor malfunctions are indicated. The turbidity record is a composite of several turbidity sensors, which have been related to each other using regressions during periods of overlapping records (see appendix A). Suspended-sediment measurements are plotted as the mean turbidity over the time of the measurement. 
Table 10. Suspended-sediment samples collected at Whitman Road Bridge, North Fork Stillaguamish River, Washington (USGS streamgage 12166300).

[Method: EDI, equal-discharge-increment; EWI, equal-width-increment. Turbidity sourcecode: 1, regression with Analite sensor; 2, native solitax; 3, regression with DTS-12 sensor. SSC: Suspended-sediment concentration. Abbreviations: EDI, equal-discharge interval; EWI, equalwidth interval; FNU, Formazin Nephelometric Unit; $\mathrm{m}^{3} / \mathrm{s}$, cubic meter per second; mg/L, milligram per liter; mm, millimeter; <, less than]

\begin{tabular}{|c|c|c|c|c|c|c|c|c|}
\hline Date & Start time & End time & Method & $\begin{array}{c}\text { Turbidity } \\
\text { (FNU) }\end{array}$ & $\begin{array}{l}\text { Turbidity } \\
\text { source } \\
\text { code }\end{array}$ & $\begin{array}{c}\text { Discharge } \\
\left(\mathrm{m}^{3} / \mathrm{s}\right)\end{array}$ & $\begin{array}{c}\text { SSC } \\
(\mathrm{mg} / \mathrm{L})\end{array}$ & $\begin{array}{c}\text { Percent } \\
\text { fine SSC } \\
(<0.063 \mathrm{~mm})\end{array}$ \\
\hline $03-27-14$ & 1335 & 1413 & EWI & 1,892 & 1 & 46 & 4,940 & 68 \\
\hline $03-29-14$ & 1150 & 1225 & EDI & 1,717 & 1 & 69 & 5,594 & 66 \\
\hline $03-29-14$ & 1452 & 1532 & EWI & 1,626 & 1 & 77 & 4,810 & 60 \\
\hline $03-30-14$ & 1030 & 1057 & EDI & 1,540 & 1 & 82 & 4,258 & 75 \\
\hline $03-30-14$ & 1425 & 1447 & EDI & 1,604 & 1 & 78 & 4,377 & 76 \\
\hline $03-31-14$ & 1305 & 1331 & EDI & 1,029 & 1 & 56 & 2,795 & 79 \\
\hline 04-01-14 & 1035 & 1114 & EDI & 1,120 & 1 & 47 & 2,177 & 78 \\
\hline 04-02-14 & 1020 & 1114 & EWI & 588 & 1 & 38 & 1,365 & 59 \\
\hline 04-03-14 & 1135 & 1232 & EWI & 494 & 1 & 31 & 919 & 74 \\
\hline 04-04-14 & 1040 & 1114 & EWI & 548 & 1 & 32 & 1,440 & 58 \\
\hline 04-05-14 & 1015 & 1055 & EWI & 408 & 1 & 31 & 873 & 72 \\
\hline 04-06-14 & 1147 & 1207 & EDI & 856 & 1 & 55 & 1,731 & 72 \\
\hline $40-07-14$ & 1018 & 1054 & EWI & 494 & 1 & 45 & 2,470 & 30 \\
\hline 04-11-14 & 1235 & 1257 & EDI & 430 & 2 & 44 & 897 & 69 \\
\hline 04-17-14 & 1220 & 1306 & EDI & 1,170 & 2 & 92 & 2,712 & 68 \\
\hline 04-18-14 & 0840 & 0928 & EWI & 1,034 & 2 & 105 & 2,340 & 69 \\
\hline 05-01-14 & 1240 & 1326 & EWI & 338 & 2 & 44 & 759 & 48 \\
\hline $05-05-14$ & 1115 & 1147 & EWI & 748 & 2 & 114 & 1,810 & 67 \\
\hline 05-09-14 & 1715 & 1740 & EDI & 770 & 2 & 124 & 2,070 & 75 \\
\hline $05-10-14$ & 0825 & 0915 & EWI & 320 & 2 & 74 & 690 & 68 \\
\hline $11-05-14$ & 0905 & 1005 & EWI & 294 & 3 & 91 & 1,085 & 47 \\
\hline $12-10-14$ & 1015 & 1027 & EDI & 220 & 3 & 83 & 570 & 67 \\
\hline 01-05-15 & 0920 & 1015 & EWI & 973 & 3 & 293 & 2,550 & 58 \\
\hline 02-05-15 & 1305 & 1405 & EWI & 365 & 3 & 90 & 1,115 & 76 \\
\hline
\end{tabular}

The relations between turbidity and total and fine SSC were well described by second-order polynomials (fig. 28). The regression constant was omitted in both regressions (known as regression through the origin; see Eisenhauer, 2003), as its inclusion led to estimates of increasing concentration with decreasing turbidity less than about 200 Formazin Nephelometric Units (FNUs), which in turn estimated unrealistically high sediment loads during most of the summer low-flow season. The relatively large and likely spurious effect of the regression constant is a result of having too few low turbidity measurements to constrain the lower end of the rating curve. The turbidity values from both raw sensor data and those estimated by regression all plot along the same curve, indicating that the composite turbidity record was consistent over time.

Between the beginning of the turbidity record on March 26, 2014, and the end of water year 2014, the total suspended-sediment load at Whitman was $430 \pm 40$ thousand metric tons (table 9). Material finer than $0.063 \mathrm{~mm}$ composed about 70 percent of that total load, or $300 \pm 25$ thousand metric tons. The total suspended-sediment load during WY 2015 was $560 \pm 70$ thousand metric tons, with the fine fraction again composing about 70 percent, or $380 \pm 45$ thousand metric tons. 

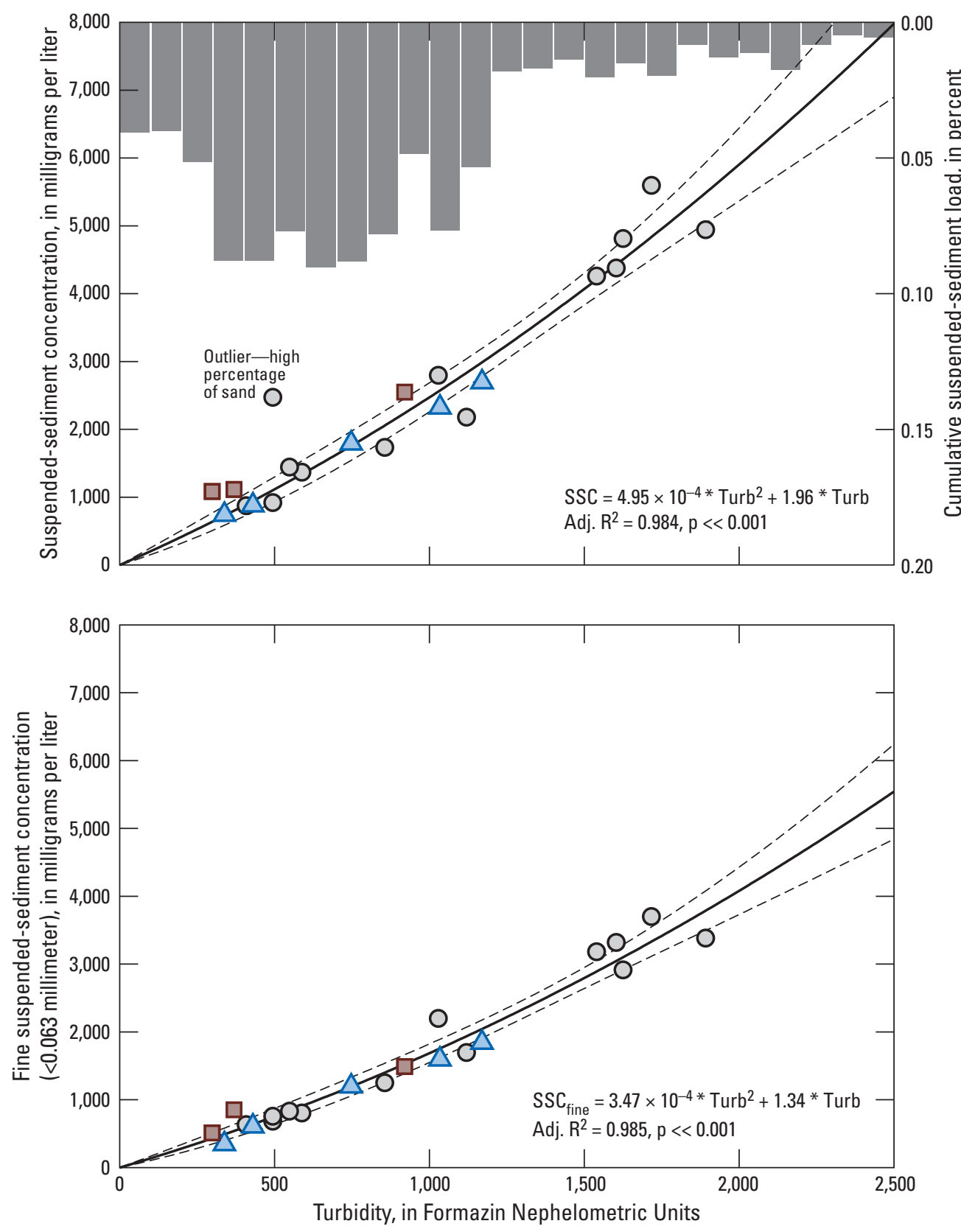

EXPLANATION

Percentage of suspended-sediment load transported in given turbidity range

Linear regression

- - 95-percent prediction interval

Suspended-sediment concentration (SSC) measurement

O Analite regression

$\triangle$ Solitax

$\square \quad$ DTS-12 regression

Figure 28. Regressions between turbidity and $(A)$ measured suspendedsediment concentrations (SSC) and ( $B$ ) suspended sediment finer than 0.063 millimeters $(\mathrm{mm})$ (SSCfine) at North Fork Stillaguamish near Oso (Whitman), Washington (USGS streamgage 12166300). Histogram in (A) shows the percentage of suspended-sediment load over the study period transported during periods of various turbidities. 


\section{Bedload}

Eleven bedload samples were collected at Whitman Road Bridge during April 2014-January 2015 (table 11) at discharges ranging from 46 to $368 \mathrm{~m}^{3} / \mathrm{s}$, corresponding to 11 to 75 percent of the 0.5 annual exceedance probability (AEP) discharge (2-year flood) (figs. 6 and 29). Average measured bedload discharge ranged from 8.44 to $152 \mathrm{~kg} / \mathrm{s}$ (table 11). Unit-width transport rates ranged from 0.2 to $3.0(\mathrm{~kg} / \mathrm{m}) / \mathrm{s}$. These high values are comparable to unit-width rates measured downstream of recent dam removals in Pacific Northwest, as well as after the 1980 eruption of Mt. St. Helens (Pitlick, 1992; Major and others, 2012; Magirl, Hilldale, and others, 2015). Bedload measurements 9 and 11 were marked by poor contact with the streambed, particularly at sections of high water velocities. In subsequent analysis, these measurements were generally determined to be outliers.

The relation between measured bedload transport and discharge was described using a power law with the inclusion of a threshold, $q_{s}=a(Q-Q c)^{b}$, where $q_{s}$ is the bedload transport rate in kilograms per second, $\mathrm{Q}$ is the discharge in cubic meters per second and $Q_{c}$ is a critical discharge below which it is presumed that no transport occurs (fig. 29). The discharge threshold was specified as $30 \mathrm{~m}^{3} / \mathrm{s}$, a low-flow value at which most of the bed was visible and little to no bedload transport was observed. This discharge corresponds to a dimensionless critical shear stress of about $0.02-0.04$, estimated using one-dimensional hydraulic model estimates of flow depth and energy slope and measured grain-size distributions from pebble counts. Two samples (collected on December 9, 2014, and January 5, 2015) were omitted from the regression as outliers. Fitting was done using ordinary least-squares regression on the log-transformed values of both transport rate and discharge. The smearing bias correction factor of Duan (1983) was used to correct for bias introduced by back-transforming the log-transformed regression into real space. The $\mathrm{R}^{2}$ value of the regression was high (0.69), but given that the upper end of the rating curve is defined by a single measurement, the statistical quality of the regression is likely an overly optimistic estimate of the true uncertainty. Although it possible that the relation between discharge and bedload transport changed over time as a result of the varying sediment input from the landslide, there are too few samples to characterize or parameterize these changes.

Over the entire period of analysis, the total bedload transport at Whitman was estimated to be $310 \pm 65$ thousand metric tons (table 9). Total bedload transport in WY 2014-LS was $65 \pm 15$ thousand metric tons, and was $245 \pm 40$ thousand metric tons in WY 2015.

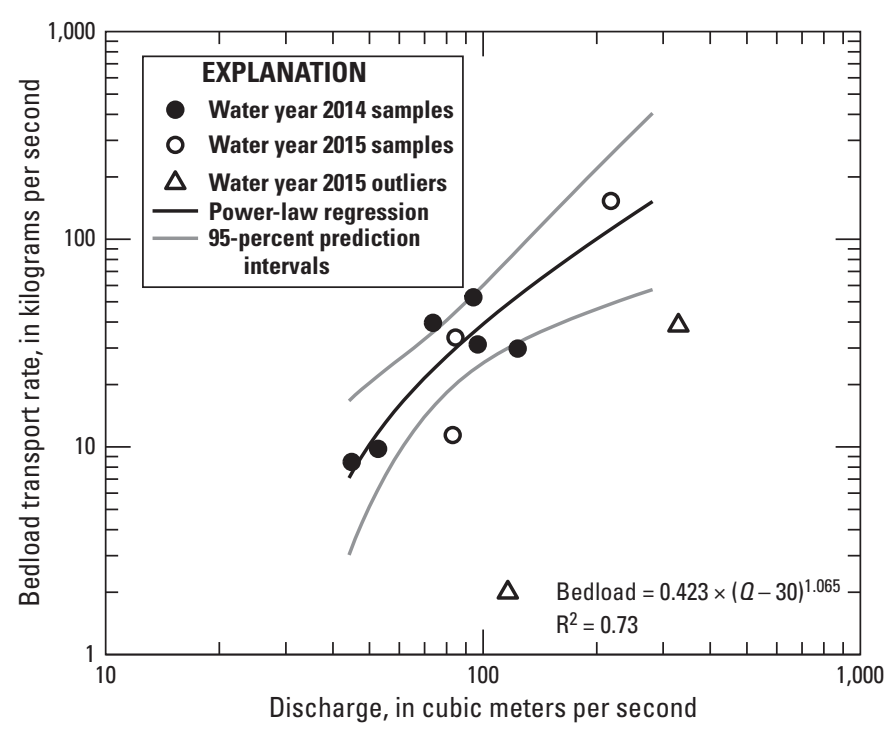

Figure 29. Measured bedload transport rates in relation to discharge at North Fork Stillaguamish River near Oso (Whitman), Washington (USGS streamgage 12166300), water years 2014 and 2015. Power-law rating curve used to estimate bedload transport over the study period is shown. Two measurements were determined to be outliers based on low measured transport rates, atypical grain-size distributions, and poor sampler bed contact at the time of sampling.

\section{Fraction of Total Load Carried as Bedload}

Concurrent measurements of bedload and suspendedsediment load allowed for direct quantification of the fraction of total sediment load carried as bedload at the time of measurement. For bedload samples with no concurrent SSC sample, the SSC could be estimated using the concurrent turbidity values and the developed SSC-turbidity rating curve. Measured bedload was between 10 and 45 percent of the total measured sediment load, with a mean of about 20 percent (table 12). These values were similar regardless of whether measured SSC or turbidity-estimated SSC was used to estimate suspended-sediment loads, and were also similar to the bedload to total load ratio estimated for the time-integrated sediment loads over the study interval (table 9). There were no clear trends in the bedload fraction over time, and the bedload fraction showed no obvious relation to discharge. 


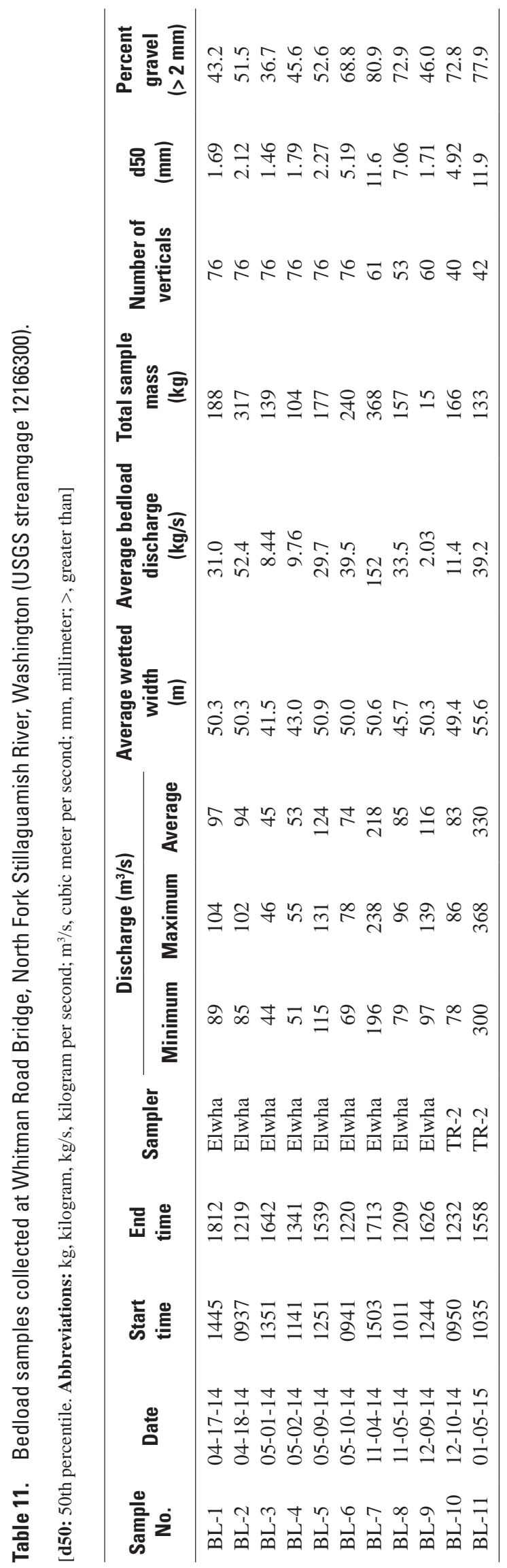


Table 12. Ratios of bedload to total load based on paired measurements of suspendedsediment and bedload transport rates at Whitman Road Bridge, North Fork Stillaguamish River, Washington (USGS streamgage 12166300).

[Abbreviations $\mathrm{kg} / \mathrm{s}$, kilogram per second; $\mathrm{m}^{3} / \mathrm{s}$, cubic meter per second; SSC, suspended-sediment concentration; -, no data]

\begin{tabular}{|c|c|c|c|c|c|c|}
\hline \multirow{2}{*}{ Date } & \multirow{2}{*}{$\begin{array}{c}\text { Mean } \\
\text { discharge } \\
\left(\mathrm{m}^{3} / \mathrm{s}\right)\end{array}$} & \multirow{2}{*}{$\begin{array}{l}\text { Bedload } \\
\text { transport } \\
\text { rate } \\
(\mathrm{kg} / \mathrm{s})\end{array}$} & \multicolumn{2}{|c|}{$\begin{array}{c}\text { Suspended-sediment } \\
\text { transport rate } \\
(\mathrm{kg} / \mathrm{s})\end{array}$} & \multicolumn{2}{|c|}{$\begin{array}{l}\text { Bedload as } \\
\text { percentage } \\
\text { of total load }\end{array}$} \\
\hline & & & Measured & $\begin{array}{l}\text { Turbidity- } \\
\text { estimated }\end{array}$ & $\begin{array}{l}\text { Measured } \\
\text { SSC }\end{array}$ & $\begin{array}{l}\text { Turbidity- } \\
\text { estimated } \\
\text { SSC }\end{array}$ \\
\hline 04-17-14 & 97 & 31 & 250 & 283 & 11 & 10 \\
\hline 04-18-14 & 94 & 52 & 245 & 225 & 18 & 19 \\
\hline 05-01-14 & 45 & 8 & 34 & 31 & 20 & 21 \\
\hline $05-02-14$ & 53 & 10 & 44 & 40 & 18 & 20 \\
\hline 05-09-14 & 124 & 30 & 249 & 262 & 11 & 10 \\
\hline 05-10-14 & 74 & 40 & 51 & 48 & 44 & 45 \\
\hline $11-04-14$ & 218 & 152 & - & 473 & - & 24 \\
\hline $11-05-14$ & 85 & 34 & 99 & 53 & 26 & 39 \\
\hline $12-09-14$ & 116 & ${ }^{1} 2$ & - & 186 & - & ${ }^{2} 1$ \\
\hline $12-10-14$ & 83 & 11 & 79 & 39 & 13 & 22 \\
\hline \multirow[t]{3}{*}{ 01-05-15 } & 330 & ${ }^{1} 39$ & 748 & 726 & ${ }^{2} 5$ & ${ }^{2} 5$ \\
\hline & & & \multicolumn{2}{|c|}{ Average, all values } & 18 & 19 \\
\hline & \multicolumn{4}{|c|}{ Average, excluding bedload outliers } & 20 & 23 \\
\hline
\end{tabular}

${ }^{1}$ Bedload value plots as outlier in figure 9.

${ }^{2}$ Value is calculated using bedload outlier.

\section{Grain-Size Distributions of Sediment Load}

Most sampled bedload material was between 1 and $45 \mathrm{~mm}$ in diameter. Sample-median grain sizes (d50) ranged from 1.5 to $12.2 \mathrm{~mm}$, and 84th-percentile grain sizes (d84) ranged from 5.7 to $41.5 \mathrm{~mm}$. Sand (material finer than $2 \mathrm{~mm}$ ) made up between 28 and 79 percent of samples, with an overall average of about 50 percent. Bedload measurements were concentrated in two time periods; the first in April and May 2014 (WY 2014) and the second between November 2014 and January 2015 (WY 2015). For a given discharge, samples collected in WY 2014 tended to be finer overall, with a smaller median grain size (d50) and a higher fraction of sand (fig. 30). The last measurement made in WY 2014, on May 10, 2014, was notably coarser and less sand-rich than a measurement collected 1 day earlier on May 9, 2014, and the grain-size distribution closely resembled measurements collected in WY 2015. Conversely, the grainsize distribution of the sample collected December 9, 2014, with poor bed contact and a clear outlier in terms of measured transport rate (fig. 29), was relatively sand-rich, and had an overall size distribution that more closely resembled measurements from WY 2014.

On two occasions (May 9, 2014, and December 10, 2014; tables 10 and 11), concurrent suspended-sediment and bedload samples were subjected to full grain-size analysis, providing the grain-size distribution of the total load and the relative abundance of various grain sizes in the two modes of transport. At the modest sampling discharges (124 and $83 \mathrm{~m}^{3} / \mathrm{s}$ ), particles between 0.25 and $2 \mathrm{~mm}$ were observed traveling in suspension and in bedload (fig. 31). Material about $0.5 \mathrm{~mm}$ in diameter traveled in approximately equal concentration between the two modes of transport. These observations provide a rationale for using $0.5 \mathrm{~mm}$ to break out the eroded landslide material into the mass of material likely to travel as bedload or suspended-sediment load (table 7). 

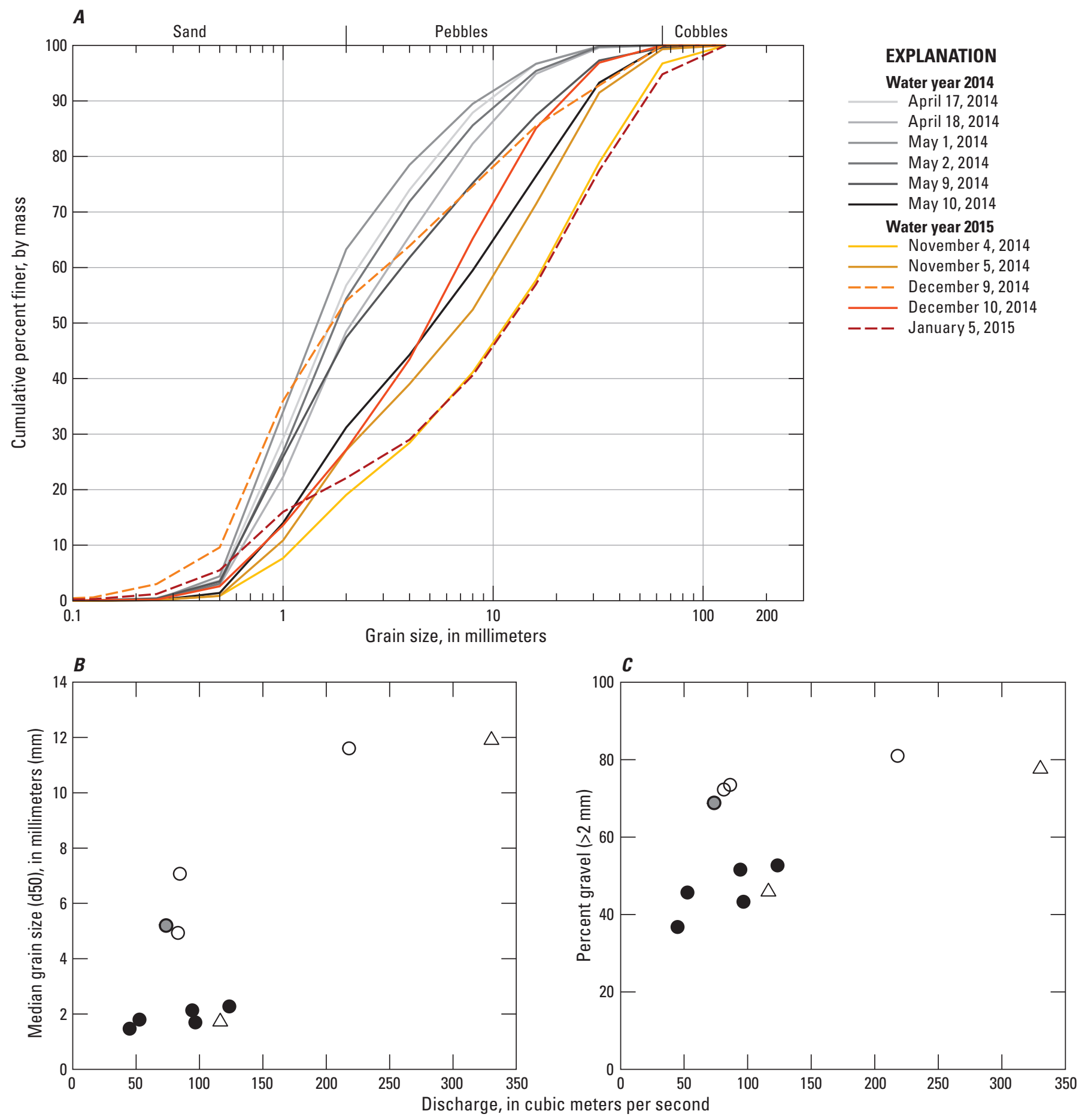

\section{EXPLANATION}

\section{Sample}

- Water year 2014-LS

O Water year 2015

O May 10, 2014

$\triangle$ Transport rate outlier

Figure 30. Grain-size distributions from bedload measurements made at Whitman Road Bridge, North Fork Stillaguamish River near Oso, Washington (USGS streamgage 12166300). (A) Full grain-size distribution of all samples. Transport rate outliers are indicated with dashed lines. Each curve represents the composite of all material collected for a given day. $(B)$ Relation between median ( $\mathrm{d} 50$ ) grain-size and discharge and $(C)$ between percent gravel (greater than 2 millimeters) and discharge. Sample collected May 10, 2014, was similar to samples collected in water year 2015. 


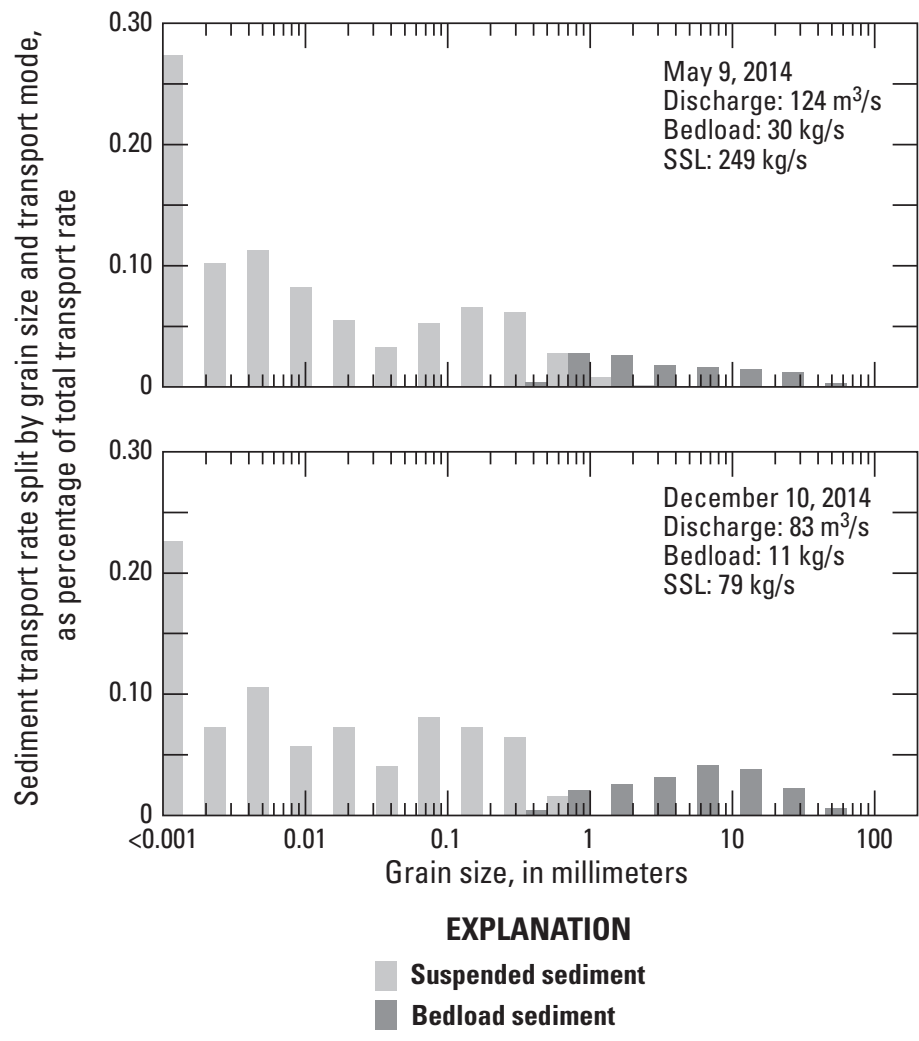

Figure 31. Percentage of the fluvial sediment load in a given grain size class and transport mode (suspended or bedload) at Whitman Road Bridge, North Fork Stillaguamish River near Oso, Washington. (USGS streamgage 12166300). Measurements indicate that material with a diameter of about 0.5 millimeter traveled in both modes of transport in about equal proportion, and were used to define the threshold for what size of landslide material would be likely to travel as bedload. $\left(\mathrm{kg} / \mathrm{s}\right.$, kilogram per second; $\mathrm{m}^{3} / \mathrm{s}$, cubic meter per second.)

\section{Stanwood}

The arrival of SR 530 Landslide sediment at the Stanwood streamgage was observed as a marked increase in turbidity on March 24, 2014, a little less than 2 days after the landslide first occurred (fig. 22). Assuming that the turbidity signal emanated from the landslide when the river overtopped the deposit (at approximately 11:30 a.m. on March 23, 2014 [Magirl, Keith, and others, 2015]), the onset of the spike in turbidity at Stanwood at 7:30 a.m. on March 24, 2014 indicates a mean velocity of $0.80 \mathrm{~m} / \mathrm{s}$, or $2.9 \mathrm{~km} / \mathrm{h}$, for the leading edge of the turbidity pulse. The minor increase in stage at Stanwood associated with the return of flow from upstream of the landslide occurred around 10:45 p.m. on March 23, 2014, indicating that the kinematic water wave traveled at about $1.4 \mathrm{~m} / \mathrm{s}$, twice the velocity of the suspended-sediment plume. The SSC samples collected at Stanwood in the days following the landslide (March 24, 25 , and 27, 2014) were composed almost entirely (99 percent) of material finer than $0.063 \mathrm{~mm}$ (Anderson and others, 2017), indicating that only the silt and clay from the landslide arrived at Stanwood at this time. The initial arrival date of landslide sand traveling in suspension is unknown, but an SSC sample collected May 5, 2014, was composed of 62 percent fine material, similar to samples collected prior to the landslide. This may indicate the arrival of landslide sand traveling in suspension, although the increase in sand also may be due to the higher discharges associated with the sample collected on May 5, 2014. Samples collected after May 5, 2014, had a mean fine-fraction of 65 percent, and did not vary systematically over time, leaving it ambiguous as to when, or whether, fine sand from the landslide arrived at Stanwood.

During the 18-month period after the landslide, Anderson and others (2017) estimated a suspended-sediment load of 1,970 \pm 400 thousand metric tons using the available turbidity record (fig. 32). The discharge-regression developed in this study estimated a suspended-sediment load of 1,400 thousand metric tons over this same period. The difference between these estimates, approximately 570 thousand metric tons (table 9), is how much estimated landslide sediment was mobilized past Stanwood in suspension during the study interval.

Based on this estimate, landslide material accounted for about 30 percent of the total suspendedsediment load in the lower Stillaguamish River between March 2014 and September 2015, and about 20 percent of the suspended-sediment load over the period of record at Stanwood, from November 15, 2013, through September 2015. The relative contribution of the landslide to Stanwood sediment load was markedly higher in WY 2014-LS than in WY 2015. Between March 22, 2014, and September 30, 2014, the landslide contributed about 50 percent of the total suspended-sediment load at Stanwood (table 13). In WY 2015, landslide sediment only contributed about 20 percent of the total suspended sediment load at Stanwood. 


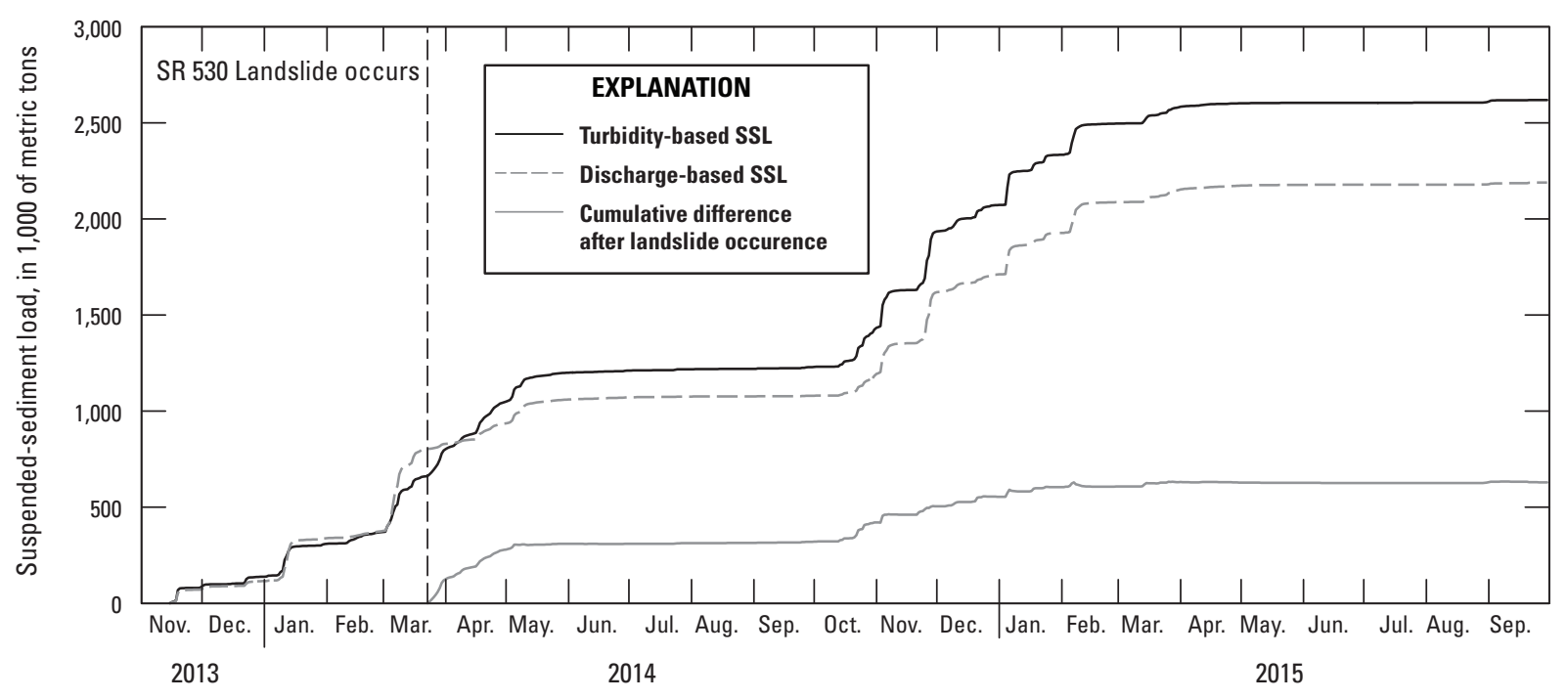

Figure 32. Cumulative suspended-sediment loads (SSL) estimated using the turbidity-suspended-sediment concentration relation and the discharge-suspended-sediment load regression for the pre-landslide period at Stillaguamish River near Stanwood, Washington (USGS streamgage 12170300). The cumulative difference is an estimate of the mass of sediment in suspension that was originally eroded from the SR 530 Landslide. Because the cumulative difference started at zero on March 22, 2014, it does not include the cumulative overestimate present in the pre-landslide period. Turbidity-based values are from Anderson and others (2017).

Table 13. Mass of landslide erosion and estimated landslide material at North Fork Stillaguamish River near Stanwood, Washington (USGS streamgage 12170300).

[Landslide erosion is reported for intervals of repeat topographic surveys that most closely align with the respective water year periods. For WY 2014-LS, reported erosion is the cumulative erosion from March 24, 2014, to July 1, 2014; for WY 2015, erosion represents cumulative erosion from July 1, 2014, to July 7, 2015. Abbreviations mm, millimeter; WY, water year; <, less than; >, greater than]

\begin{tabular}{|c|c|c|c|c|c|c|}
\hline \multicolumn{3}{|c|}{ Study period } & \multirow{2}{*}{$\begin{array}{c}\text { Suspended- } \\
\text { sediment load } \\
(1,000 \text { metric tons })\end{array}$} & \multirow{2}{*}{$\begin{array}{l}\text { Landslide sediment } \\
\text { in suspended- } \\
\text { sediment load } \\
(1,000 \text { metric tons })\end{array}$} & \multicolumn{2}{|c|}{$\begin{array}{l}\text { Landslide erosion from } \\
\text { topographic differencing } \\
(1,000 \text { metric tons })\end{array}$} \\
\hline Period & Start & End & & & $<0.5 \mathrm{~mm}$ & $>0.5 \mathrm{~mm}$ \\
\hline WY 2014-LS & $03-22-14$ & 09-30-14 & $570 \pm 90$ & 290 & 380 & 43 \\
\hline WY 2015 & $10-01-14$ & 09-30-15 & $1,400 \pm 170$ & 280 & 360 & 39 \\
\hline Entire study & $03-22-14$ & 09-30-15 & $1,970 \pm 400$ & 570 & 740 & 82 \\
\hline
\end{tabular}




\section{Bedload-Transport Modeling}

To assess whether there were reaches of the North Fork Stillaguamish River where channel conditions may preferentially promote the deposition of landslide sediment, bedload transport capacities were calculated along the full length of the study area using empirical sediment transport equations. Reaches with consistently low or rapidly decreasing transport capacities would be more likely to experience aggradation. Those transport capacities, estimated over a range of flows, also were used to create bedload rating curves, which, applied to the available discharge records allowed the calculation of integrated bedload transport capacity over the study period. These annual transport capacities then provide a means of assessing if the sediment input from the landslide was likely to exceed the river's ability to transport that sediment.

The transport capacities calculated using empirical transport equations provide an estimate of bedload transport rates under idealized conditions of sediment supply (Gomez and Church, 1989). These conditions are only rarely met in natural settings, and the estimated transport capacities tend to overestimate true bedload transport rates in natural rivers. However, conditions in the sediment-rich and predominantly alluvial North Fork Stillaguamish River were deemed sufficiently close to those idealized conditions that the transport capacities estimated herein still provide a useful estimate of both the spatial trends and absolute magnitude of bedload transport rates. Bedload transport rates, and the equations used to estimate those rates, are also highly sensitive to small changes in transport conditions. The downstream transport of landslide sediment would likely be accompanied by topographically subtle and spatially complex changes in bed topography and surficial texture that static inputs did not capture. As such, the primary goal here is to assess the magnitude and longitudinal trends of estimated bedload transport capacities under the conditions present during summer 2014. No attempt was made to dynamically model the downstream transport of landslide sediment.

Inputs to the bedload equations include field-based measurements of surficial grain size and local hydraulics, estimated using one-dimensional hydraulic modeling. Transport capacities were then estimated across various flow conditions at 131 locations between rkms 4.6 and 56, reflecting the locations of cross sections used in the hydraulic model. At a given location, calculated transport capacities across a range of discharges were used to construct a sediment rating curve, and in combination with local discharge records, used to estimate transport capacities for March 22, 2014, through September 30, 2015.

\section{Model Inputs and Development}

\section{Selected-Sediment Transport Equations}

Three bed-material transport formulas were used to evaluate bedload transport capacity: Parker (1990a, 1990b), Wilcock and Crowe (2003), and Recking (2013). These multiple equations take different approaches for calculating bedload transport that result in a range of estimates that help assess the uncertainty of the analysis and to better identify consistent trends. These equations have been successfully applied to other gravel-bed rivers (for example, Wilcock and others, 2009; Wallick and others, 2010; Pourhosein and others, 2015). For each of these models, bedload transport capacities are calculated as a function of channel geometry, hydraulic flow parameters, and surficial grain-size data. The Parker (1990a, 1990b) and Wilcock and Crowe (2003) equations are theoretically similar and use a distribution of surficial grain size to estimate size-specific transport rates and include hiding functions that capture the effects of small particles sitting in protected spaces between larger particles. The Parker (1990a, 1990b) equation was developed using empirical data from a small stream in Oregon. This equation was developed to be used with input particle-size distributions truncated at less than $2 \mathrm{~mm}$, under the assumption that sand predominantly travels in suspension. The Wilcock and Crowe (2003) surface model was developed from flume observations of bed-material transport using various grain sizes under varying flows. This model uses the full surface grain-size distribution of the bed and includes a variable critical shear stress that decreases as the sand fraction increases. The Recking (2013) formula is intended to estimate reach-scale mean transport rates, and can use either a hydraulic radius or the ratio of discharge to wetted width for the computation of the hydraulics and transport rates; both variations were evaluated for this study and are herein referred to as HR-Recking and Q-Recking, respectively. The Recking (2013) formula calculates a dimensionless shear stress as a function of the 84th percentile grain-size statistic, as opposed to the 50th percentile used in the other equations, asserting that coarser material play a dominant role in modulating bed shear stress, bed mobility, and armoring of supply of finer particles. The Recking (2013) formula only incorporates the 84th and 50th percentile of the surficial grains-size distribution in its calculations, and in contrast to the Parker (1990a, 1990b) equation and Wilcock and Crowe (2003) model equations, does not calculate size-class specific transport rates. 


\section{Inputs and Methods for Bedload Transport Modeling}

\section{Surficial Grain Size}

Surficial grain-size information used in the sediment transport calculations are based on modified Wolman pebble counts (Wolman, 1954) made along the North Fork Stillaguamish River during July and September 2014 (Keith and Anderson, 2017). A minimum of 100 clasts were measured for all pebble counts, and were typically made along the apex of gravel bars. On larger gravel bars or in morphologically complex areas, multiple measurements at a site were made to better characterize the mean sediment-size distribution, including measurements made at the heads and toes of bars.

Only a small fraction of the cross-sections in the HEC-RAS model were co-located with grain-size measurements, which required the determination of what grain-size distribution should be applied to the remaining cross sections. These decisions were made based on a combination of spatial proximity and reach-breaks (figs. 33-34; Keith and Anderson, 2017). Multiple samples collected at a single site were averaged. The composite for the C-Post reach, almost exclusively based on measurements near the C-Post Bridge, was also applied to the Barco, Swede Heaven, and SR 530 Landslide reaches. The Whitman reach was sub-divided in three parts. The median particle diameters (d50) for individual grain-size measurements ranged from about $50 \mathrm{~mm}$ to less than $2 \mathrm{~mm}$ (fig. 34). The d50 for the composite curves, representing the average of closely-spaced measurements, ranged from 13 to $34 \mathrm{~mm}$. The variability of d50s between the composite curves is smaller than the variability between multiple individual measurements along the length of a single bar, and no clear downstream trends in grain size were observed (fig. 33).

Much of the variability between the composite curves is caused by variability in the sand fraction (fig. 34). When the composite curves are re-plotted as gravel distributions, omitting the fraction of material finer than $2 \mathrm{~mm}$, the curves are reasonably similar with the exception of the Rowan reach composite. The modest variability of gravel grain-size distributions over the study reaches, and the absence of a clear downstream trend, then indicates that the composite grain-size distributions should be approximately valid for reach-scale analysis even when applied to cross sections several kilometers away from the measurement location.

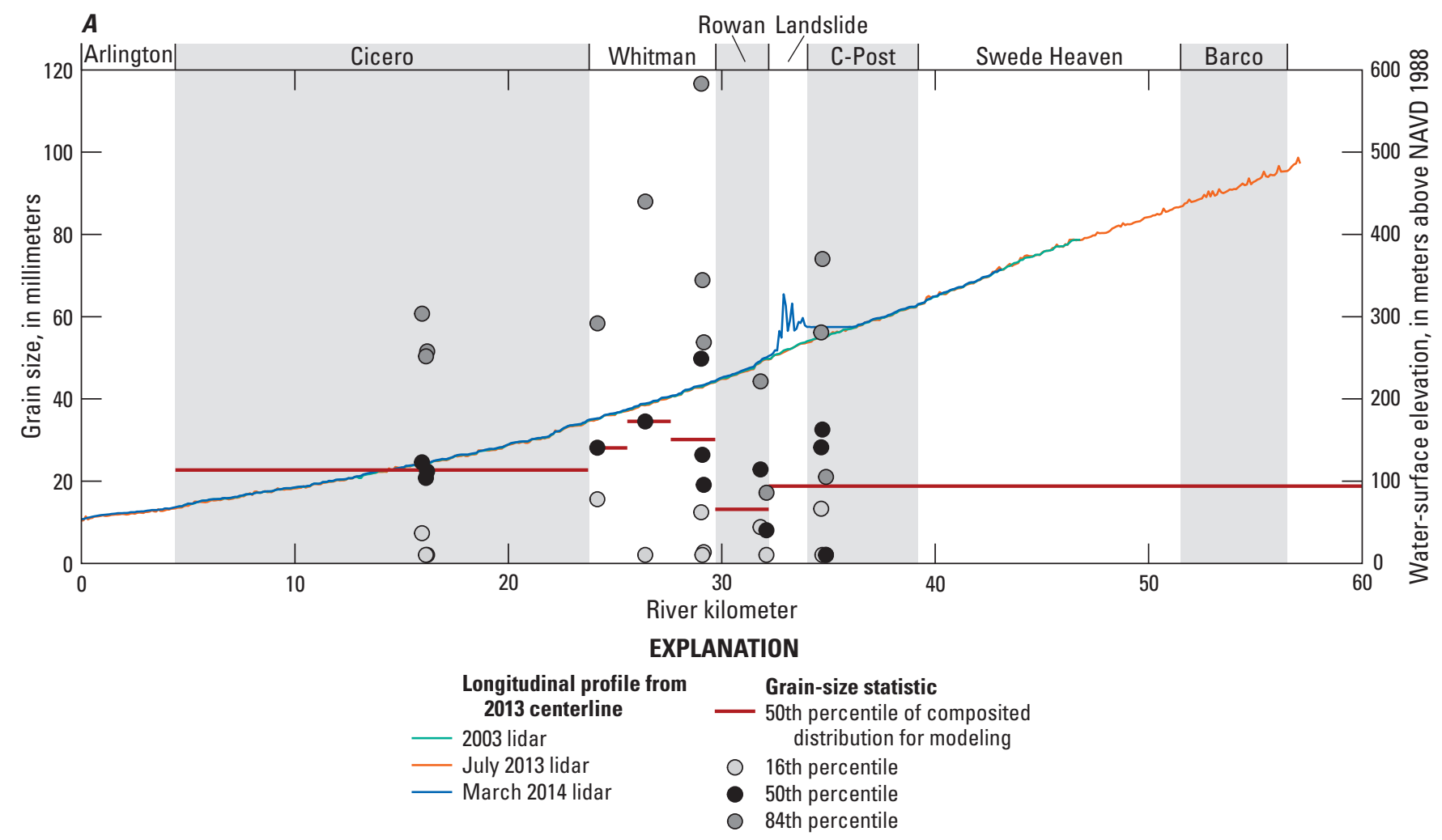

Figure 33. Water-surface elevation based on aerial lidar, and surficial grain-size characteristics from measurements made at the North Fork Stillaguamish River, Washington, summer 2014. Horizontal lines indicate the median composite grain size using bedload transport modeling and the extents over which composite grain-size distributions were applied. 


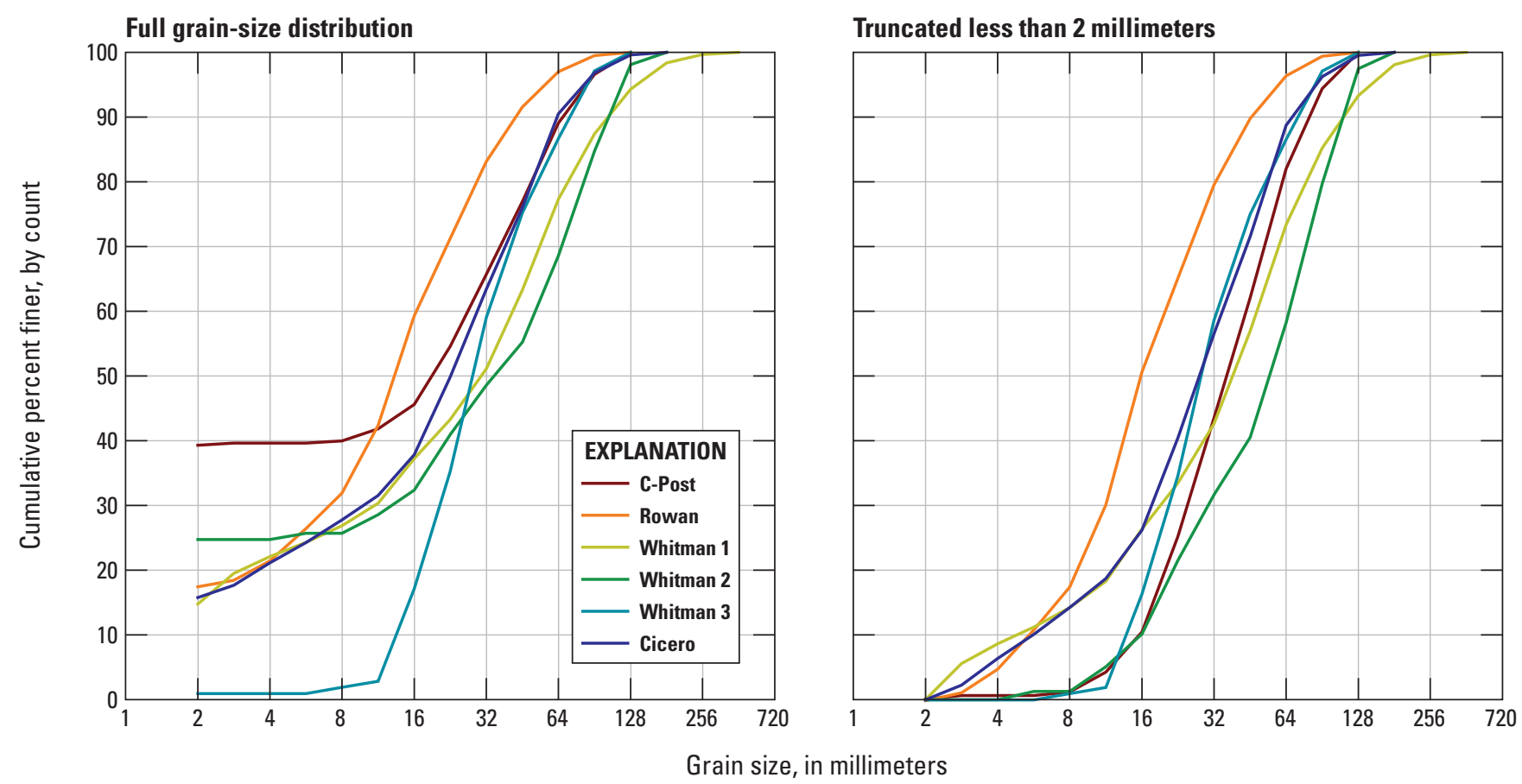

Figure 34. Grain-size distributions used in sediment-transport modeling at selected reaches, North Fork Stillaguamish River, Washington, water year 2014. The grain-size distribution near C-Post was applied to all reaches upstream of the landslide. The samples from the Rowan reach were applied to the Rowan and SR 520 Landslide reaches. Three subreaches in the Whitman reach were given unique grain-size distributions, labeled 1 through 3 in upstream to downstream order (see fig. 33).

\section{Uncertainty in Grain-Size Measurements}

Sources of error in pebble counts can arise from operator sampling bias, variation in site location or time, and collection technique (for example, Bunte and Abt, 2001; Olsen and others, 2005; Daniels and McCusker, 2010). In order to quantify the variability of the collected data, several of the pebble counts collected in 2015 were subset into two sets of 100 clasts collected along two parallel tapes by separate team members, providing two independent measurements over essentially identical swaths of the gravel bars. The percentage difference between d16, d50, and d84 values for parallel measurements was typically less than 15 percent and no more than 31 percent except for one sample at the Whitman site, where the differences ranged from 21 to 60 percent.

\section{Hydraulic Parameters from One-Dimensional} Hydraulic Modeling

A Hydraulic Engineering Center River Analysis System (HEC-RAS) Version 4.1 model (U.S. Army Corp of Engineers, 2010) was used to simulate hydraulic conditions along the North Fork Stillaguamish River, providing estimates of energy slope, hydraulic radius, and wetted width at various locations along the river. The model was developed in 1979 for the Federal Emergency Management Agency and the geometry was updated in 2015 by Snohomish County, using lidar data from July 2013 and April 2014 as well as bathymetric data from January 2015 (Zach Brown, Snohomish County, written commun., 2015). This most recent version was calibrated by Snohomish County to the high-water mark from the December 12, 2010, flood of record for the USGS streamgage 12176000 (North Fork Stillaguamish River near Arlington $\left(1,560 \mathrm{~m}^{3} / \mathrm{s} ; 55,100 \mathrm{ft}^{3} / \mathrm{s}\right)$. The geometry of the model within the landslide reach was updated using the March 18, 2015, SfM subaerial topography, but retained the January 2015 bathymetry present in the original Snohomish County model. No other changes were made to the underlying geometry used in the model. Eight flow scenarios were simulated for conditions of steady, subcritical flow. The flow scenarios were selected to fully span the range of discharges recorded during the study period and were described using AEPs calculated by Magirl, Keith, and others (2015) from the long-term streamflow record at Arlington. Scenarios included the 0.50, $0.10,0.04,0.02$ and 0.01 AEP (2- to 100-year) flows as well as 50,25 , and 12.5 percent of the 0.50 AEP flow (table 14). 
Table 14. Annual exceedance probability flow scenarios and discharges for the North Fork Stillaguamish River near Arlington, Washington (USGS streamgage 12167000).

[Flow scenario: Annual exceedance probabilities (AEPs) for North Fork Stillaguamish River near Oso (USGS streamgage 12166300) are scaled based on the ratio of mean annual flows at the two sites (0.64), and are not based on site-specific discharge records. Abbreviations $\mathrm{ft}^{3} / \mathrm{s}$, cubic foot per second; $\mathrm{m}^{3} / \mathrm{s}$, cubic meter per second]

\begin{tabular}{lrrrr}
\hline \multirow{2}{*}{$\begin{array}{c}\text { Flow } \\
\text { scenario }\end{array}$} & $\begin{array}{c}\text { Arlington } \\
\left(\mathbf{m}^{\mathbf{3}} \mathbf{/ s}\right)\end{array}$ & $\begin{array}{c}\text { Whitman } \\
\left(\mathbf{m}^{\mathbf{3}} / \mathbf{s}\right)\end{array}$ & $\begin{array}{c}\text { Arlington } \\
\left(\mathbf{f t}^{3} / \mathbf{s}\right)\end{array}$ & $\begin{array}{c}\text { Whitman } \\
\left(\mathbf{f t}^{\mathbf{3}} \mathbf{/ s}\right)\end{array}$ \\
\hline $0.125 * 0.50 \mathrm{AEP}$ & 85 & 55 & 3,000 & 1,900 \\
0.250*0.50 AEP & 170 & 110 & 6,000 & 3,800 \\
0.500*0.50 AEP & 340 & 220 & 12,000 & 7,700 \\
0.50 AEP & 680 & 430 & 24,000 & 15,400 \\
0.10 AEP & 968 & 620 & 34,200 & 21,900 \\
0.04 AEP & 1,160 & 740 & 41,100 & 26,200 \\
0.02 AEP & 1,260 & 810 & 44,600 & 28,500 \\
0.01 AEP & 1,350 & 860 & 47,700 & 30,500 \\
\hline
\end{tabular}

These flow estimates are valid for the reach surrounding the streamgage at Arlington. At locations upstream and downstream of the streamgage, the flow values were scaled according the estimated mean annual flow at various locations in the basin. The ratios of mean annual flows were estimated based on the flow estimates provided in the NHDPlus V2 hydrologic dataset (McKay and others, 2012). This increased the number of reaches with distinct discharges for a given flow scenario from 2 to 35 . The hydraulic model used for this report, including minor geometry updates near the landslide and the increased number of flow change locations was used for high-level riverine and geomorphic assessments, and was not intended for, and should not be used for, flood modeling or flood inundation near the landslide or elsewhere. Additional details about model validation efforts over a range of flows are presented in appendix A.

\section{Implementation of Transport Equations and Methods for Load Estimation}

The hydraulic results from the HEC-RAS model (fig. 35) and grain-size information (fig. 34) were used to calculate bedload transport capacities using the four sediment transport equations for each cross section, and for each of the flows for which the hydraulic model was run. These calculations were completed using scripts developed in the R statistical programming language. This differs from the work of Magirl, Keith, and others (2015), in which bedload transport capacities were calculated using the Bedload Assessment in Gravel-bedded Streams (BAGS) software (Pitlick and others, 2009; Wilcock and others, 2009). Although the underlying bedload transport equations remain unchanged, the two implementations result in slightly different effective input values. BAGS performs numerical calculation of a water-surface elevation based on an input cross section; prior to calculation, BAGS subdivides the cross section into 50 equal-width sections, which may result in an imprecise characterization of the main channel for cross sections that include large expanses of flood plain. BAGS then estimates transport capacities based on the hydraulic radius over the entire cross section; as a result, the software may calculate decreasing hydraulic radii, and consequently decreasing transport rates, with increasing discharge as the flows spread across the floodplain and hydraulic radius decreases. These issues were avoided in the $\mathrm{R}$ implementation by using hydraulic radii estimated in HEC-RAS only over the lateral extents of the primary channel, excluding the floodplains.

The estimates of bedload transport capacities for various discharge scenarios (fig. 36) were used to create bedload rating curves, which, applied to the discharge record, allowed for estimating the total integrated transport at all 131 cross sections during the entire study period. The discharges applied in the calculations of bedload transport capacities were the same scaled versions of the record at the Arlington streamgage (12167000) used in the hydraulic modeling and described therein. No discharges over the study interval exceeded the maximum discharge used in the hydraulic model; however, discharges less than the minimum simulated discharge (12.5 percent of $0.5 \mathrm{AEP} ; 85 \mathrm{~m}^{3} / \mathrm{s}$ at the Arlington streamgage, $55 \mathrm{~m}^{3} / \mathrm{s}$ at Whitman streamgage) were frequent during the summer months (fig. 6). This minimum flow scenario was used as a transport threshold, and it was assumed that no significant bedload transport occurred at discharges less than this value. Observations during summer low flows indicate that little, if any, bedload transport was occurring under low flow conditions and total loads at flows less than 12.5 percent of the 0.5 AEP would be unlikely to constitute a meaningful fraction of the total annual load. 


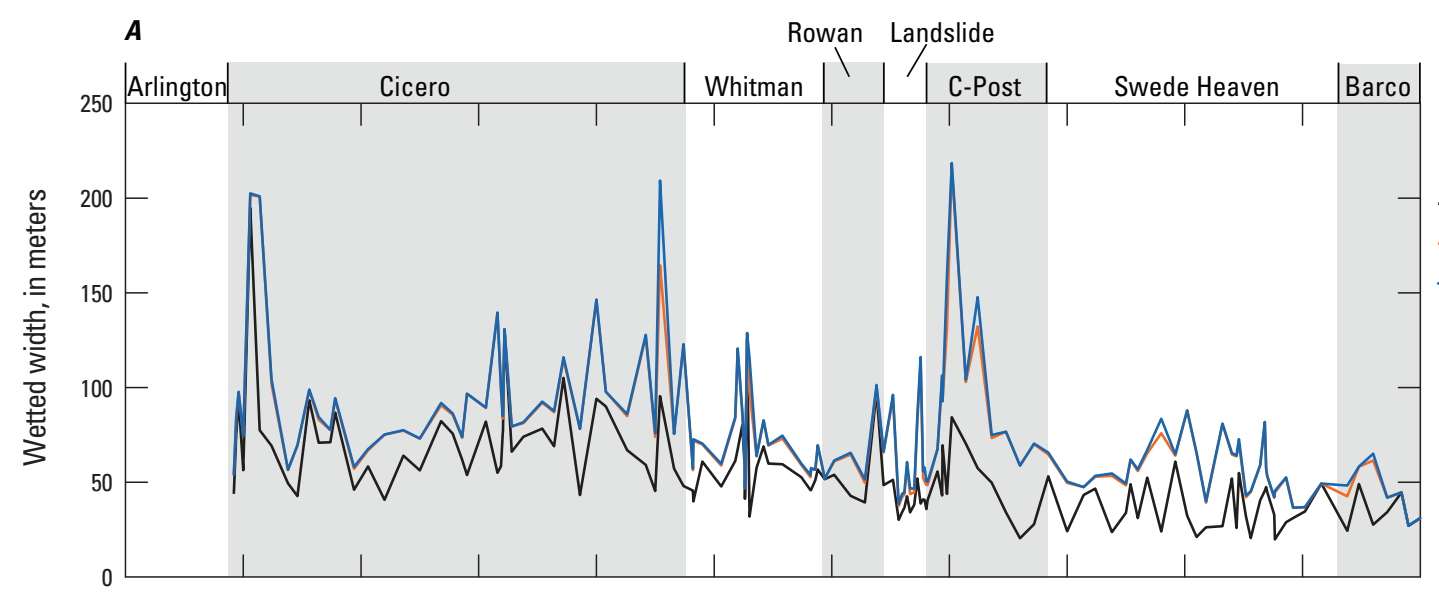

EXPLANATION

Discharge scenario

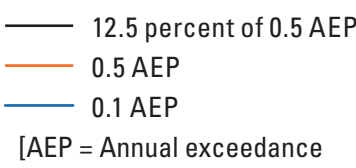
probability]
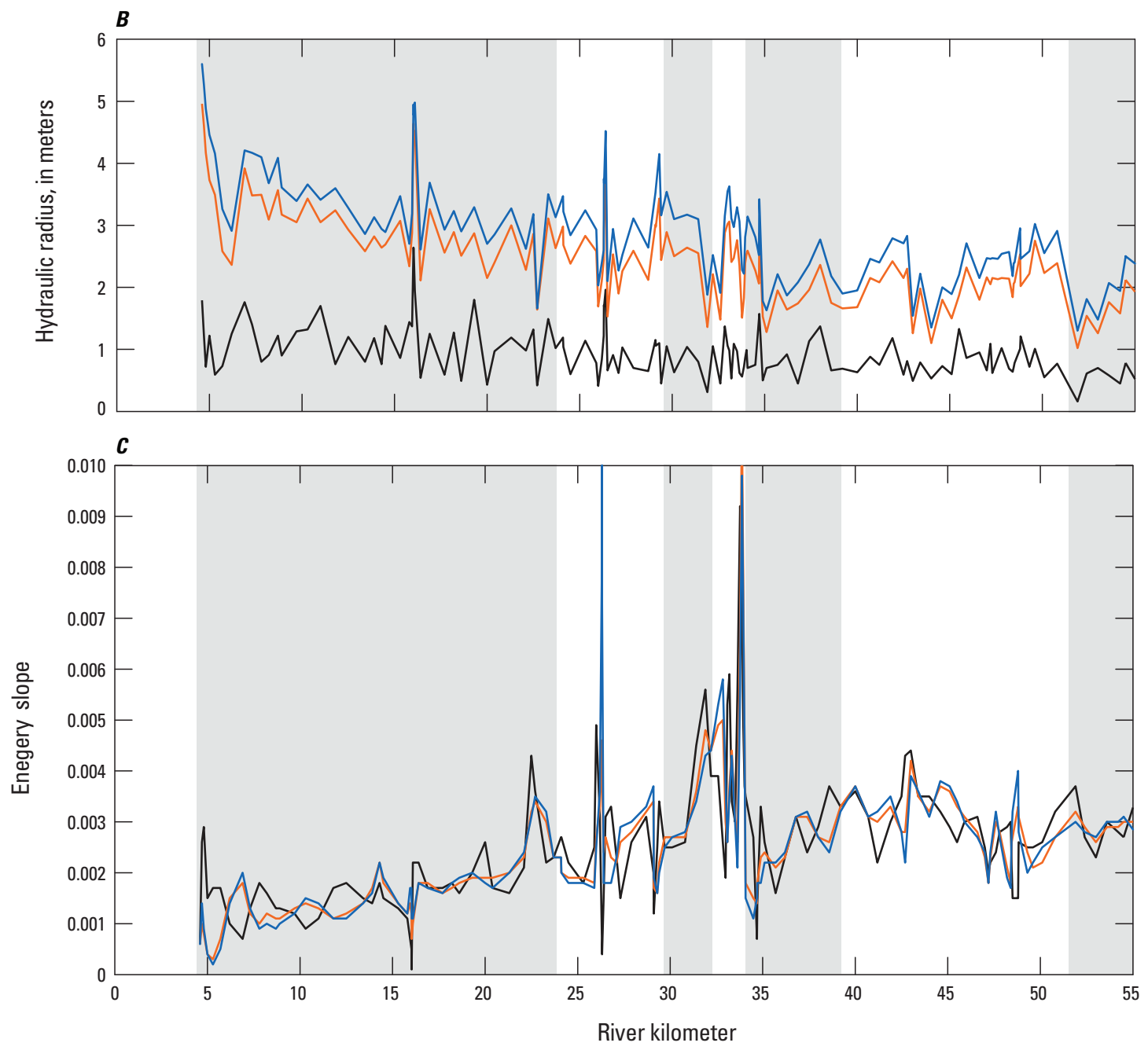

Figure 35. Sediment transport calculations from $(A)$ wetted width, $(B)$ in-channel hydraulic radius, and $(C)$ energy slope from one-dimensional hydraulic models, North Fork Stillaguamish River near Oso, Washington. Results shown for low flows ( 12.5 percent of 0.5 annual exceedance probability [AEP]), average floods (0.5 AEP) and large floods (0.1 AEP). 
Parker (1990a, 1990b)

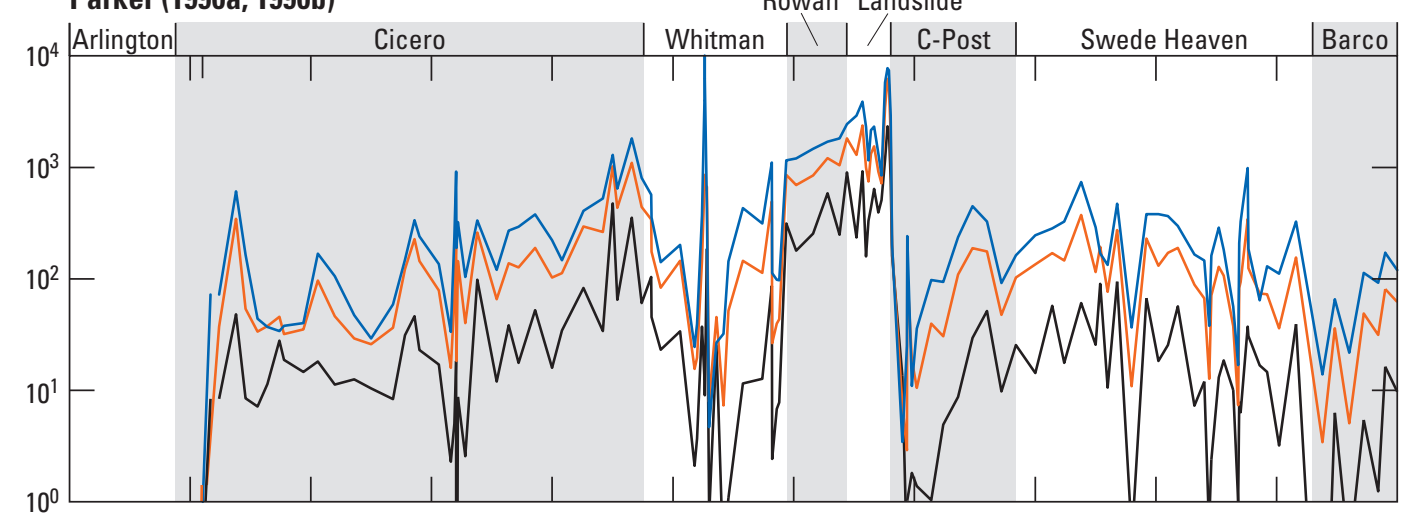

EXPLANATION Discharge scenario

- 50 percent of 0.5 AEP

- $0.5 \mathrm{AEP}$

$0.1 \mathrm{AEP}$

$[A E P=$ Annual exceedance probability]
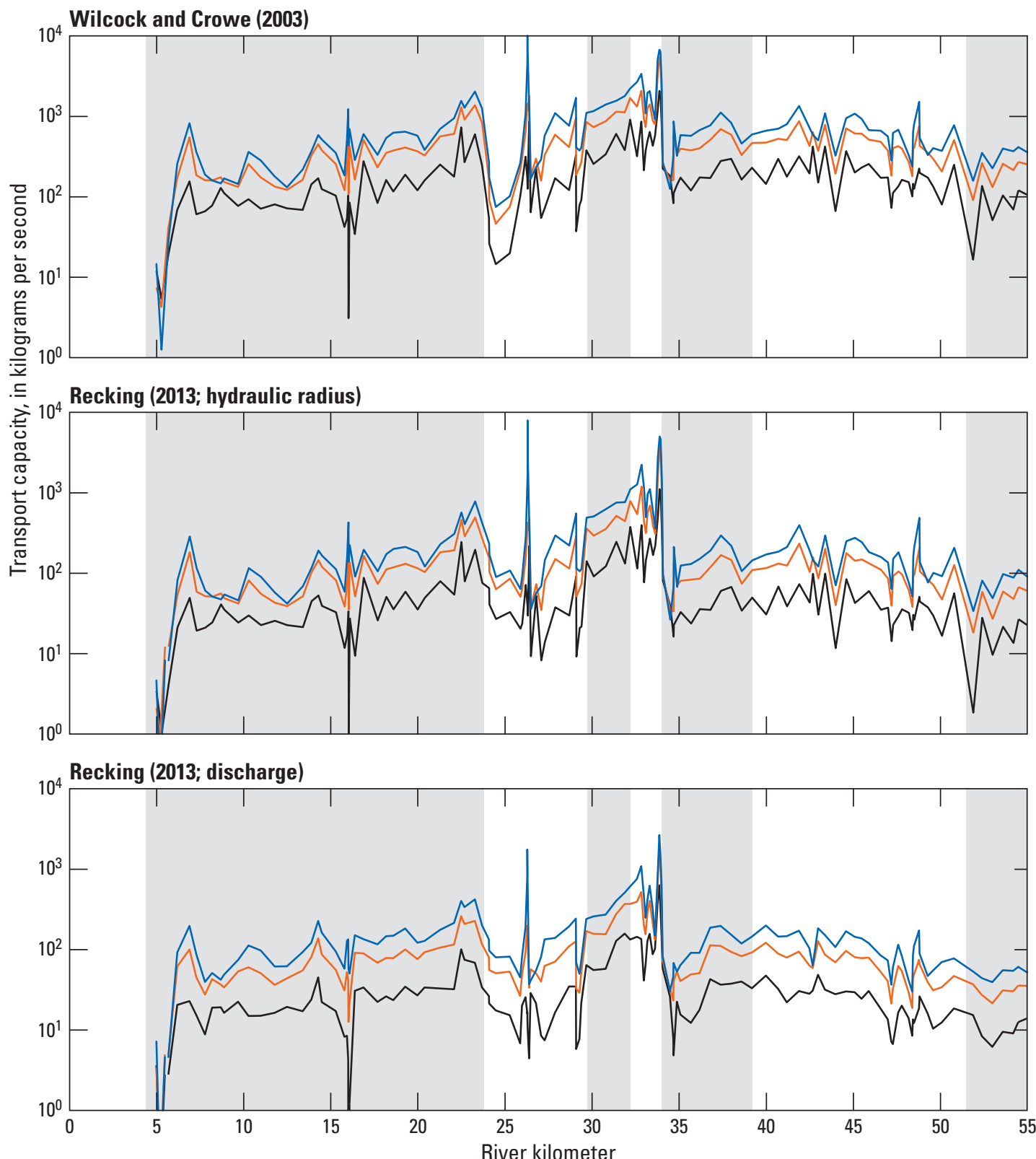

Figure 36. Calculated transport capacities for a range of moderate to high flows for four transport equations along the North Fork Stillaguamish River, Washington. 


\section{Model Results}

A comparison of measured bedload transport at Whitman Road Bridge and the calculated transport rates from the various equations indicates that the Wilcock and Crowe (2003) equation likely provides the most realistic estimates downstream of the landslide, particularly when results are averaged over reach scales (see appendix A). Given that sand made up a large fraction of both the coarse $(>0.5 \mathrm{~mm})$ landslide input and measured bedload transport, the relative success of the Wilcock and Crowe (2003) equation can be physically explained by the explicit treatment of sand transport. In contrast, the Parker (1990a, 1990b) equation uses particle-size distributions that are truncated at less than $2 \mathrm{~mm}$, and provides no information about sand transport. The Recking (2013) equations make use of only the 84th and 50th percentile grain sizes to characterize the sediment load, and are intended as an estimate of gravel transport. However, the Parker (1990a, 1990b) and Recking (2013) equations still provide an estimate of the coherency of spatial trends, and results are presented from all equations.

Although uncertainty in the transport estimates is not explicitly quantified, it is likely to be large. As a rough estimate, the variance in integrated transport capacities during the entire study period from sequential cross sections is about a factor of 2. Because it is not likely that true annual loads would actually vary substantially over distances of several hundred meters, that variability provides a rough estimate of the uncertainty at any given point. However, the reach-average loads and spatial trends are expected to average out some of that noise, and should be more accurate than the estimates at any one point.

\section{Longitudinal Trends in Bedload Transport Capacity}

In the context of potential morphologic effects of the SR 530 Landslide, the most significant estimated spatial trend was the sharp decrease in bedload transport capacity through the Rowan reach and into the upstream end of the Whitman reach (rkm 29; fig. 37, table 15). That trend was consistent across all transport equations and over the full range of moderate to high flows that would be expected to transport most of the bed material load (fig. 36). The sharp decrease in bedload transport capacities at the downstream end of the Rowan Reach is a result of decreasing flow depths and energy grades as the channel becomes less confined, as well as a coarsening of the grain size used in the model (fig. 33). Because bedload transport capacities are consistently high through the Rowan reach, the decreasing transport rates represent the first and most likely place landslide sediment would be deposited after initial entrainment. Farther downstream, there is a spike in bedload transport capacities at a bridge crossing near rkm 26.3 (Oso Bridge), but are otherwise consistent through the Whitman Reach. The Wilcock and Crowe (2003) equation indicates that there may be a secondary zone of low transport at the far downstream end of the Whitman reach, near rkm 25, although this estimate is not corroborated by the other equations. The divergence in estimates occurs because the Wilcock and Crowe (2003) equation calculates a critical shear stress based on the fraction of sand in the imposed grain-size distribution, which was low in the downstream-most extents of the Whitman Reach (fig. 34). In contrast, the Parker equation (1990a, 1990b) uses a constant critical shear stress and the Recking (2013) equation uses a slope-dependent critical shear stress. The zone around rkm 25 may then also be a zone of potential deposition if the mechanics underlying the Wilcock and Crowe (2003) equation are reasonable in this setting.

Deer Creek enters the North Fork Stillaguamish River near rkm 24 (fig. 1), and the increased discharge and a local increase in slope combine to substantially increase bedload transport capacities over several kilometers downstream of the confluence. Bedload transport capacities then begin to decrease monotonically as a function of the decreasing energy slope, except for a large spike in estimated bedload transport capacities caused by the high-energy slopes near the Cicero Bridge. There is a relatively sharp decrease in bedload transport capacities at about rkm 22, and a more gradual decrease farther downstream. Rkm 22 may then represent another potential zone of deposition. However, the continued increase in ambient loads, primarily due to input from Deer Creek, would be expected to decrease the relative magnitude of the landslide sediment and therefore decrease the likelihood of any substantial deposition.

Figure 37. On opposite page (p. 53). Cumulative bedload transport capacity during the study period along the North Fork Stillaguamish River, Washington, during March 22, 2014-September 30, 2015. (A) All estimates from Parker (1990a, 1990b), Wilcock and Crowe (2003), and Recking (2013) equations. (B) Estimates smoothed using a five-point moving average (effective smoothing over 2-3 kilometers) and restricted to primary study reaches. Spikes near rkm 26.5 and 17 are a result of simulated hydraulic conditions near bridges. The magnitude of the coarse (>0.5 millimeter [mm]) landslide sediment input and the total bedload transport at USGS streamgages are included for comparison. Bedload at USGS streamgage 12166150 (Swede Heaven) was estimated by assuming that bedload represents between 15 and 30 percent of total load, and has not been validated by any bedload measurements. 


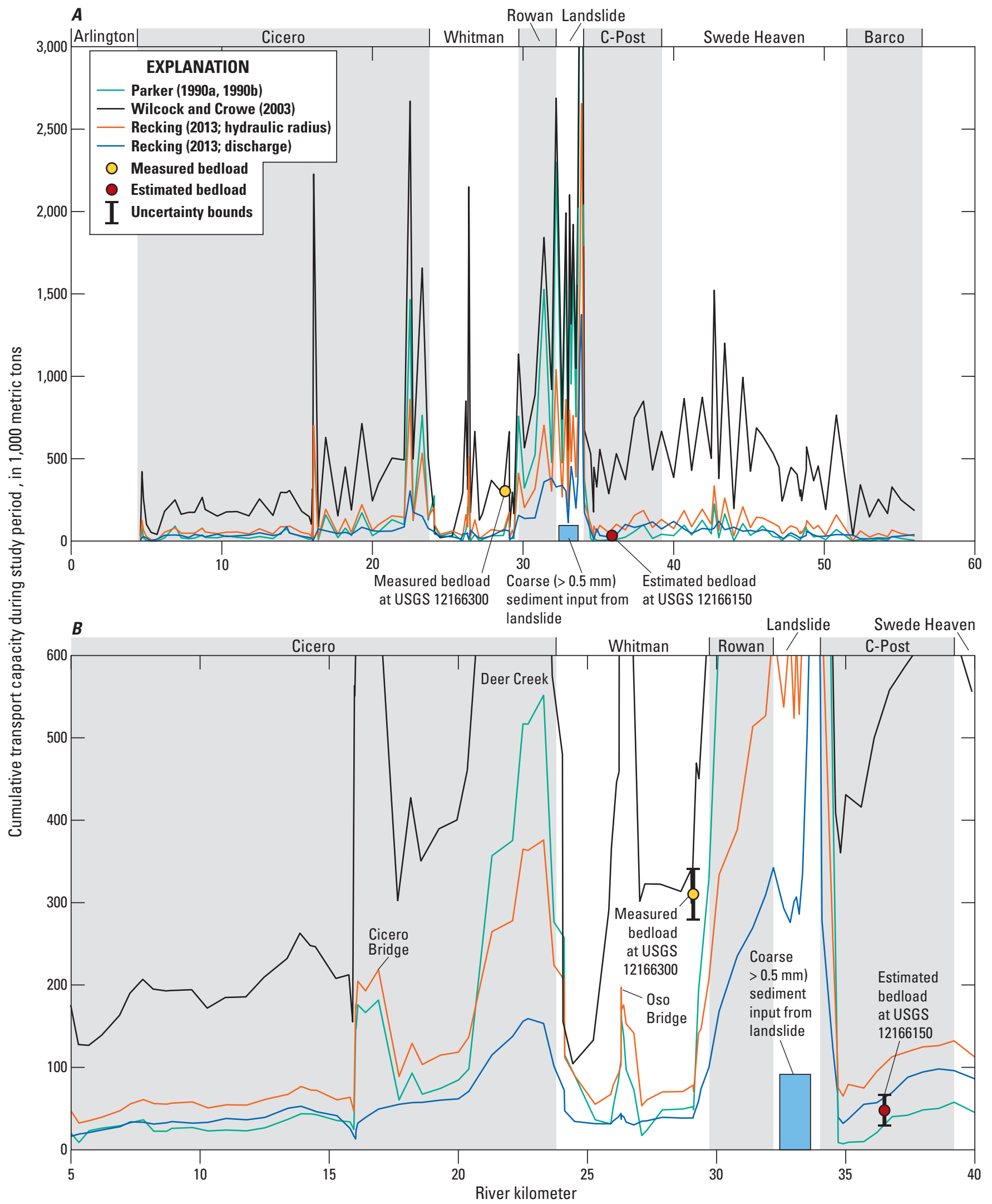

Figure 37. See bottom of left-facing page for figure title. 


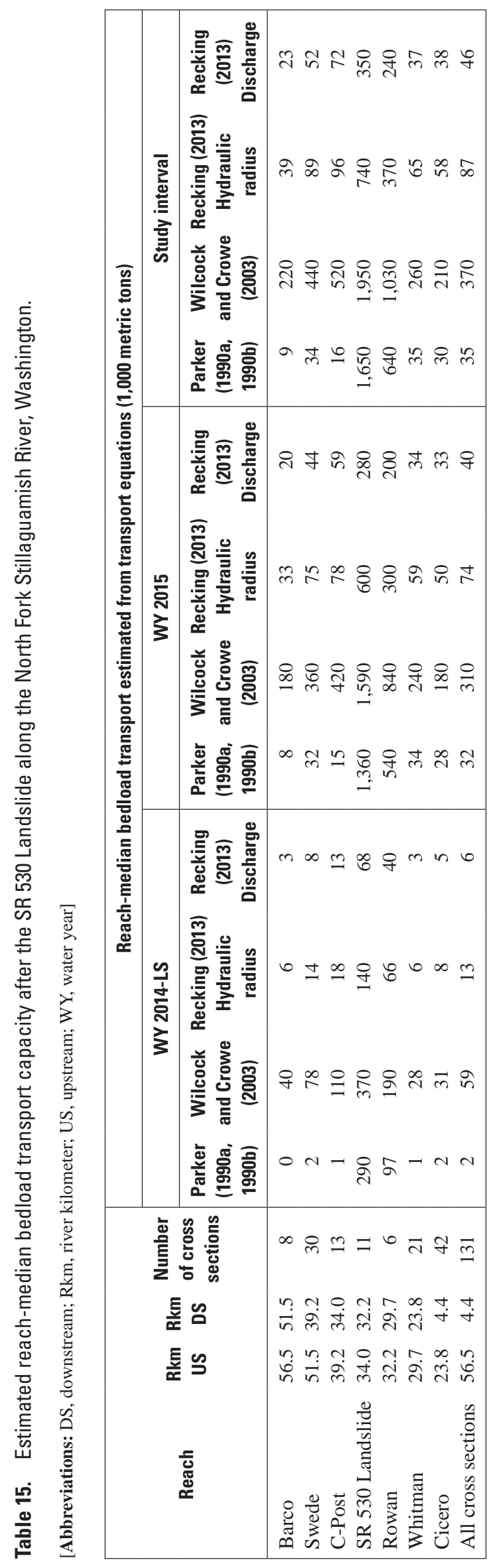


Magnitude of Estimated Bedload Transport Capacities

The integrated bedload transport capacities over the 18-month study interval calculated using the Wilcock and Crowe (2003) equation ranged from 200 to 500 thousand metric tons in the Barco to C-Post reaches, in the Whitman Reach, and in the upper Cicero reach. Annual bedload transport capacities of 1,000-3,000 thousand metric tons were estimated through the Landslide, Rowan and lower Cicero reaches. Based on the assessment that the Wilock and Crowe (2003) estimates are the most reasonable for this study and because these transport capacities are substantially larger than the coarse sediment input from the landslide, these result indicate that coarse sediment from the landslide likely transited most of the entire North Fork Stillaguamish River Basin during the study period. Integrated bedload transport capacities for the Parker (1990a, 1990b) and Recking (2013) equations were typically between 20 and 100 thousand metric tons in the reaches upstream of the landslide, in the Whitman reach and in the lower Cicero reach. Annual bedload transport capacities for those three equations increased to between 500 and 1,500 thousand metric tons in the Landslide, Rowan, and upper Cicero reaches.

\section{Downstream Channel Responses to Landslide Sediment}

Direct measurements of the downstream channel response to landslide sediment during the study period provided information about how landslide sediment was being mobilized downstream, providing a better understanding of likely downstream effects in the future. Observations of channel change include (1) morphologic change just downstream of the landslide, seen in repeated topographic surveys; (2) planform changes in downstream reaches documented in aerial photographs taken in 2013, prior to the landslide, and in the summer 2015, after the landslide; (3) localized vertical channel change, made directly by measured cross sections and indirectly through analysis of changing stage-discharge relations; (4) variations in surficial grain size, documented using measurements made in 2014 and 2015 by the USGS and between post-slide measurements and a series of pre-slide measurements collected between 2005 and 2009 by the Stillaguamish Tribe of Indians.

\section{Downstream Channel Change and Grain Size Response Methods}

Channel change in the reach just downstream of the landslide was monitored using the topographic datasets and methods described in section, "Erosion of Landslide Deposit." Analysis of planform changes was based on simple qualitative comparisons of 2013 and summer 2015 aerial imagery. Estimates also were made of at-a-site vertical channel change, and data were collected to assess changes in surficial grain size.

\section{Assessing Local Vertical Channel Change}

Vertical changes in the bed of the North Fork Stillaguamish River were monitored at several sites using specific gage analysis and repeat cross sections. Specific gage analysis uses changing relations between stage and discharge to assess vertical changes in the channel bed (Juracek and Fitzpatrick, 2009; East and others, 2015). Specific gage analysis requires independent measurements of stage and discharge at a location over time. The Swede Heaven streamgage, upstream of the landslide, was used as an independent discharge record. Two fixed discharges were selected for analysis: $21 \mathrm{~m}^{3} / \mathrm{s}\left(750 \mathrm{ft}^{3} / \mathrm{s}\right)$, and $50 \mathrm{~m}^{3} / \mathrm{s}$ $\left(1,750 \mathrm{ft}^{3} / \mathrm{s}\right)$. Both discharges are low enough that flows are contained within the low-flow channel and indicate changes in mean bed elevations over those lateral extents; therefore, results do not necessarily capture changes occurring on higher bar surfaces. All timestamps in which the discharge at Swede Heaven was within $1.5 \mathrm{~m}^{3} / \mathrm{s}\left(50 \mathrm{ft}^{3} / \mathrm{s}\right)$ of the two discharges were identified and the stage at the equivalent time for all downstream streamgages was recorded. Because only the relative change in stage over time is of interest, and not the absolute elevation, the results for each site and target discharge were normalized by subtracting the mean value, removing the discharge-related offset in absolute states between the two target discharges. Because the target discharges included a $3 \mathrm{~m}^{3} / \mathrm{s}$ window, many 15-minute measurements of stage were retained every time discharge increased or decreased through those windows. To simplify presentation, the time and stage of sequential measurements with no more than 1 hour between them were averaged together to form a single data point.

Prior to March 22, 2014, continuous stage and discharge records are available at the Whitman site from a streamgage operated by the Washington State Department of Ecology. 
To augment the specific gage analysis, a regression was created between the stage at Whitman and the stage at the USGS streamgage near Arlington, accounting for travel time, for the months immediately preceding the landslide. This regression then was used to estimate stage at Whitman for the period after the landslide, and systematic deviations between the estimated and recorded stages interpreted as a measure of the mean vertical change of the bed at the Whitman streamgage. This record measures change relative to the pre-landslide condition and includes the entire post-landslide period. However, the Arlington and Whitman streamgages are separated by a significant distance over which several large tributaries enter. The result is a correlation with substantial short-term variability, as well as seasonal variability as a function of relative base flows. These factors make fine-scale interpretation of bed-elevation change from this secondary record more difficult.

In addition to the stage-based estimates, bed change was also monitored directly by repeat cross sections at the Rowan, Whitman, and 221st Avenue streamgage sites. These cross sections document bed elevation changes at the exact site of the streamgages, generally located in pools or glide reaches. These locations may change independently of the downstream hydraulic control. As such, the cross sections and specific gage analyses, although nominally co-located, provide two independent measures of change in different hydraulic settings. Cross sections were acquired using various methods, including RTK-GNSS surveys, total station surveys, and bridge-board soundings. Because bridge-board soundings include only submerged areas of the cross section, these cross sections do not always include the full width of the active channel. To quantify change over time, the mean elevation of the channel was computed only over lateral extents for which data were available in all surveys.

\section{Assessing Surficial Grain-Size Distributions}

Grain-size measurements on samples collected from bar surfaces prior to the landslide and several times after the landslide were used to determine if the eroded landslide sediment altered the surficial bed texture. In addition to the 13 samples collected in 2014 that were used in bedload transport modeling, additional 8 samples were collected in 2015 approximately co-located with 2014 sampling sites (Keith and Anderson, 2017). Grain-size samples prior to the landslide were collected by the Stillaguamish Tribe of Indians from 2005 to 2009 between C-Post Bridge (rkm 34.7) and Whitman Road Bridge (rkm 29.1) (Jody Brown, Stillaguamish Tribe of Indians, written commun., 2014). The pre-landslide measurements on samples collected by the Stillaguamish Tribe of Indians used the same modified Wolman pebble count method used for this study, but a minimum grain size of $4 \mathrm{~mm}$ was used instead of the $2 \mathrm{~mm}$ minimum grain size used by this study. The samples collected by the Stillaguamish Tribe of Indians did not distinguish size classes greater than $256 \mathrm{~mm}$. Most pre- and post-landslide samples were collected at the apex of well-formed gravel bars; some samples were collected at the head and toe of larger or morphologically complex bars.

Given a limited number of samples, and the lack of exactly re-occupied sampling locations, data were aggregated into three primary periods (pre-slide, WY 2014, and WY 2015) and two spatial groups; upstream of the landslide, including all samples collected in the C-Post reach, and downstream, including all samples in the Rowan and Whitman reaches. Considerable variability was noted in the fraction of fine material (defined as material finer than $4 \mathrm{~mm}$ for consistency with the pre-slide data); therefore, truncated particle counts also were analyzed, including only material coarser than $4 \mathrm{~mm}$, to separate variations in sand (and gravel from 2 to $4 \mathrm{~mm}$ ) content from variations in coarse material.

\section{Geomorphic Change Just Downstream of the Landslide}

The 1-km reach just downstream of the SR 530 Landslide was most directly affected by the delivery of landslide sediment, and consequently the geomorphic response to the landslide was most significant in this area. Differencing of the pre-landslide July 2013 lidar and the March 24, 2014, lidar indicated a $0.5-2 \mathrm{~m}$ increase in the low-flow watersurface elevation as a result of sediment deposition over the $0.5-\mathrm{km}$ of channel directly downstream of the landslide (fig. 38). Detectable increases in the low flow water-surface extended to $1.5 \mathrm{~km}$ downstream of the landslide by April 6, 2014 (fig. 11). Aggradation occurred in several distinct wedges in low-gradient pool or glide reaches, acting to smooth out the stepped pool-riffle profile present in the 2013 lidar. Aerialphotography from April 6, 2014, shows the development of mid-channel gravel bars with mild braiding near rkm 32 (fig. 38C); however, the general channel and gravel bar configuration remained stable through this period.

Figure 38. On opposite page (pg. 57). Planform and vertical change just downstream of the SR 530 Landslide, North Fork Stillaguamish River near 0so, Washington. Aerial photographs were taken (A) September 10, 2013; (C) April 6, 2014, and (E) July 7, 2016. Lidar images of net geomorphic change from pre-landslide conditions: $(B)$ July 2013 to April 6, 2014, 2 weeks after the landslide; $(D)$ change from April 6, 2014, through July 7, 2015; and (F) sum of change from July 2013 to July 7, 2015. Pervasive apparent positive vertical change in $(D)$ and $(F)$ is an artifact of differencing bare-earth lidar, in which vegetation has been filtered out, with Structure-from-Motion (SfM) topography, which only provides the elevation of the vegetation canopy. 
A. September 10, 2013

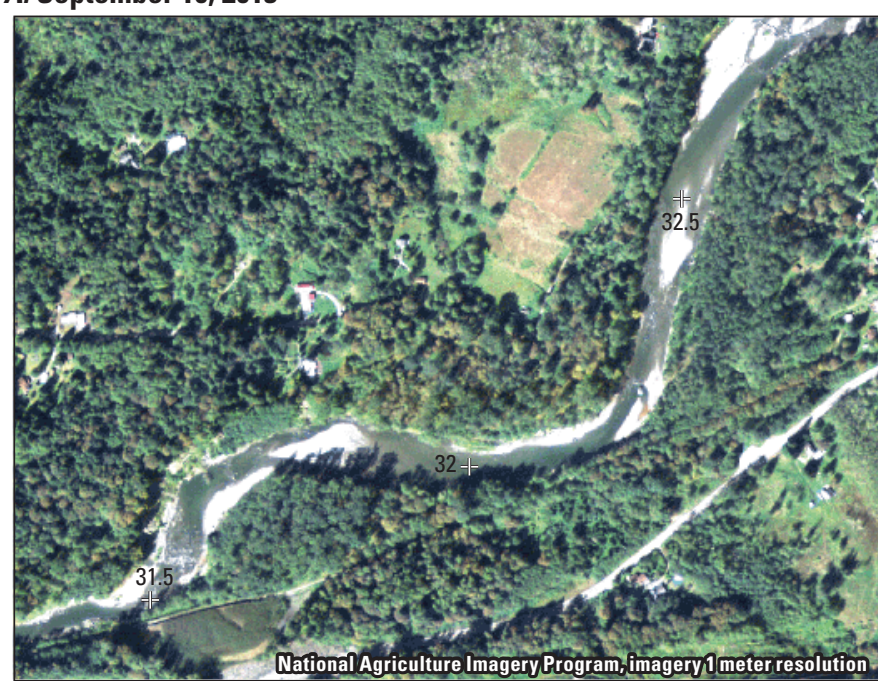

C. April 6, 2014

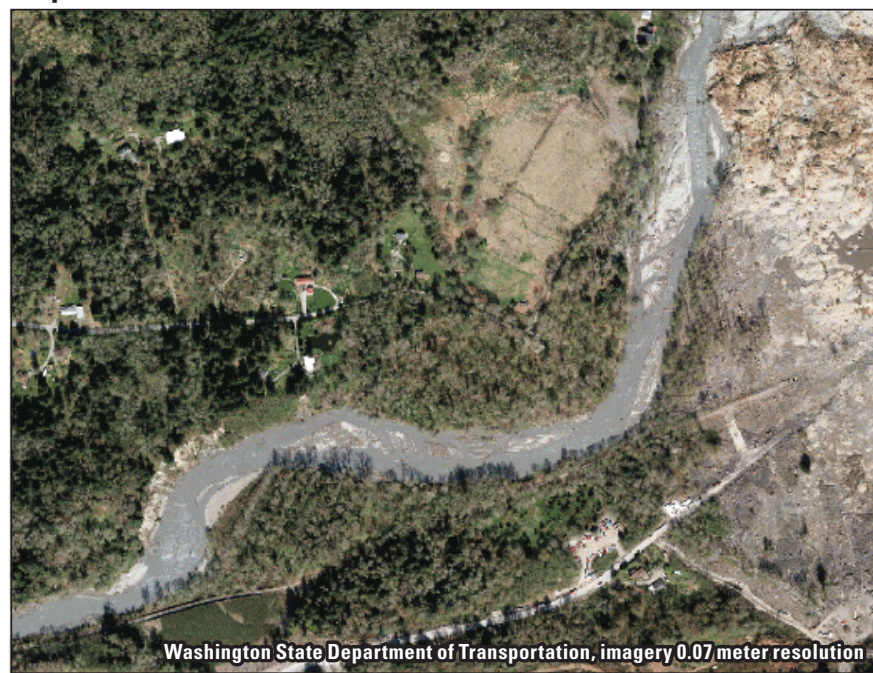

E. July 7, 2015

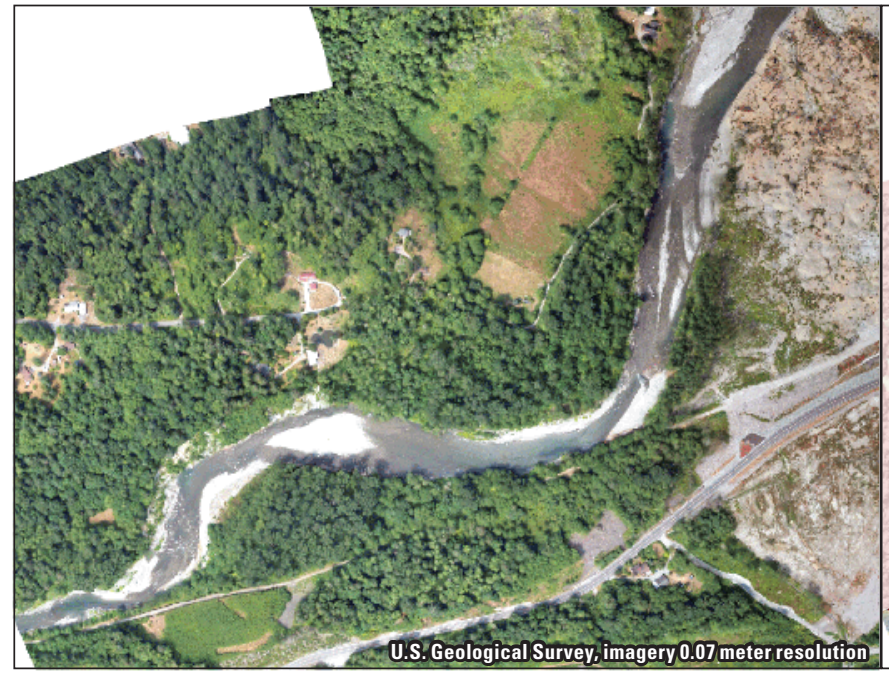

Figure 38. See bottom of left-facing page for figure title.
B. July 2013 to April 6, 2014

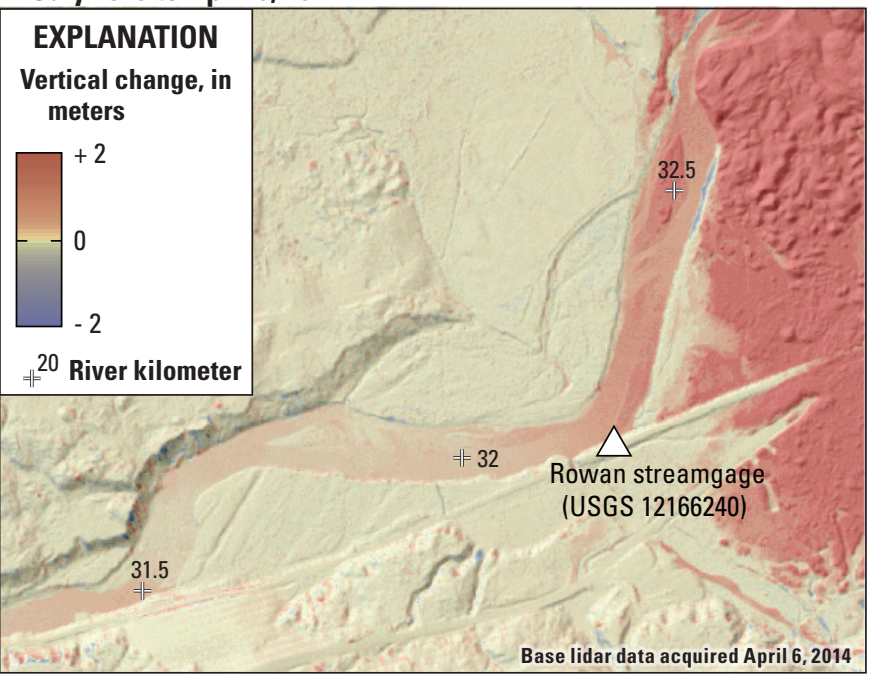

D. April 6, 2014 to July 7, 2015

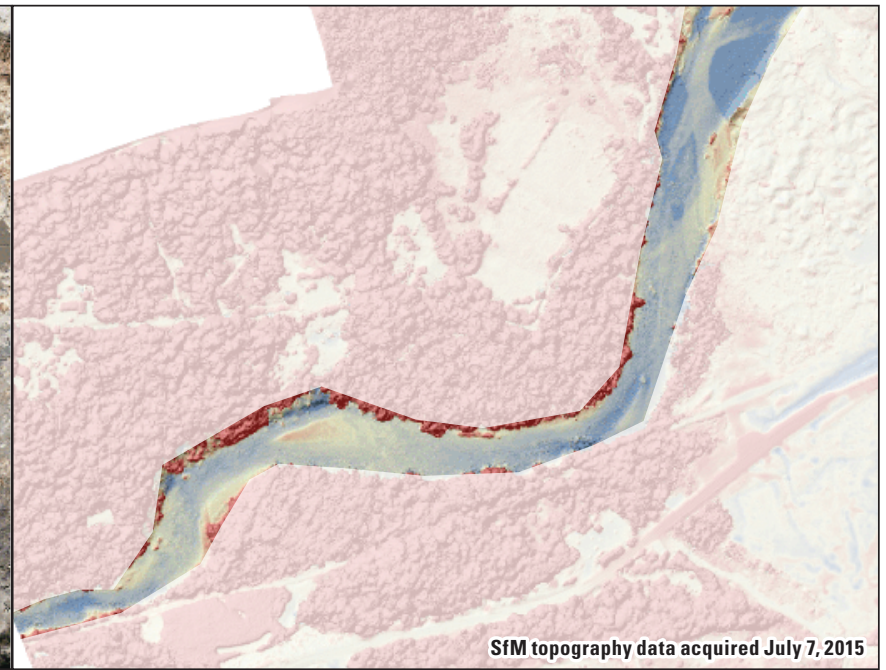

F. July 2013 to July 7, 2015

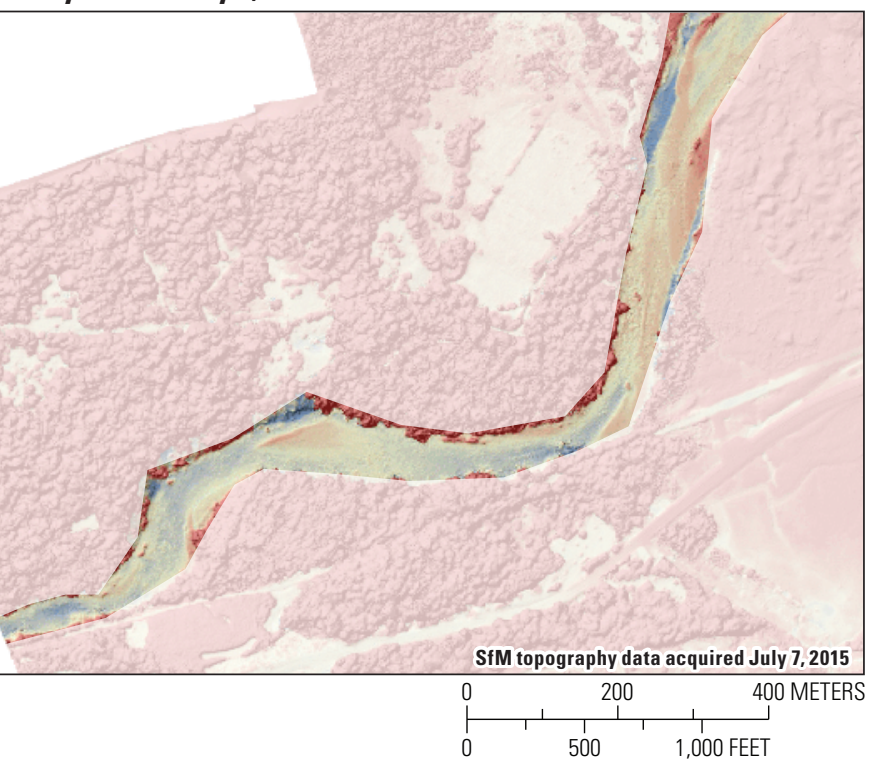


The channel was net incisional between April 6, 2014, and July 1, 2014, indicating that the peak geomorphic response and aggradation occurred sometime between those dates. Based on field observations and aerial photographs, aggradation in this reach likely peaked sometime in April. As of July 7, 2015, water-surface elevations that were substantially higher than the pre-landslide elevations from the 2013 lidar were only evident over about $200 \mathrm{~m}$ just downstream of the landslide deposit, and the overall channel configuration was not markedly different from the pre-landslide condition (figs. 11 and $38 \mathrm{E}$ and F). Outside of the wetted channel, landslide sediment did accumulate on pre-existing gravel bars, most prominently on the channel island bar at rkm 31.8. The depth of deposition ranged from about 0.2 to $0.5 \mathrm{~m}$. As of July 2015 , about 5,000 $\pm 3,000 \mathrm{~m}^{3}$ of material new material was estimated to remain stored on top of pre-existing gravel surfaces and in the remaining wedge of in-channel deposition.

The specific gage analysis at Rowan (12166240) provided a temporally resolved record of vertical channel change just downstream of the landslide starting in October 2014; results indicate that the river incised $0.8 \mathrm{~m}$ in the early part of water year 2015 (fig. 39). This incision occurred in two distinct steps of about $0.4 \mathrm{~m}$ each. The first incision event occurred on October 22, 2014, during the first significant flood of WY 2015 , with a peak flow of $180 \mathrm{~m}^{3} / \mathrm{s}$ $\left(6,500 \mathrm{ft}^{3} / \mathrm{s}\right)$ at the Whitman streamgage. The second step of incision occurred on November 4, 2014, during a flood with a peak flow of $400 \mathrm{~m}^{3} / \mathrm{s}\left(14,000 \mathrm{ft}^{3} / \mathrm{s}\right)$. After November 4 , 2014, net vertical change was minimal, despite several subsequent flows of about $400 \mathrm{~m}^{3} / \mathrm{s}$. Minor change after November 4, 2014, followed a pattern of gradual aggradation over low-flow periods followed by incision during high-flows, with variations of about $10 \mathrm{~cm}$. Nearly identical trends appear in both the Whitman and Whitehorse records, potentially indicating a shared downstream response. However, changes in the stage-discharge relation at the reference site at Swede Heaven also would create an apparent shared change in the downstream streamgages, leaving the source of the trends uncertain. Two cross section measurements at the Rowan streamgage show a net lowering of $0.81 \mathrm{~m}$ over the course of water year 2015, corroborating the specific gage analysis (fig. 39C). The inner low-flow channel narrowed and deepened, but the overall channel configuration remained otherwise unchanged.

\section{Downstream Channel Change}

The clearest vertical channel response to the landslide sediment downstream of the first kilometer below the landslide was a pulse of aggradation observed at the Whitman streamgage, $5 \mathrm{~km}$ downstream of the landslide (fig. 40).
Both the specific gage analysis and the Arlington-Whitman stage regression indicate that aggradation began on or near March 31, 2014, and peaked in mid-April 2014 at about $0.3 \mathrm{~m}$ above the pre-landslide channel elevation. The channel control incised about $0.2 \mathrm{~m}$ from mid-April through May 2014 and stabilized at about $0.1 \mathrm{~m}$ above the pre-landslide elevation on or around May 10, 2014. The observed incision coincided with the two highest peak flows in WY 2014-LS. During the WY 2015 flood season, the control was dynamic but did not show any systematic trend toward aggradation or incision. At the onset of low flows in April 2015, the channel remained about $0.1 \mathrm{~m}$ above the pre-landslide condition.

Cross sections taken at the Whitman Road Bridge show variability in the mean channel elevation of about $0.3 \mathrm{~m}$, but little net change over the entire study interval (fig. 40). A large fraction of the mean elevation change was a result of the infilling or scour of the pool on the river-right of the cross section. Net aggradation was observed in mid- to late April 2014, immediately after the landslide, and between late September and early November 2015, during the first high flows of the flood season. Incision was observed between April and September 2014, and, to a lesser degree, from early November 2014 through June 2015.

Specific gage analyses at the Whitehorse streamgage, $7 \mathrm{~km}$ downstream of the landslide, and at the 221st Avenue Bridge, $10 \mathrm{~km}$ downstream, showed random fluctuations in the elevation of their respective controls of $0.1-0.2 \mathrm{~m}$ in WY 2015 (fig. 41). There was a weak incisional trend at the Whitehorse streamgage and weak aggradational trend at the 221st Avenue streamgage, both on the order of centimeters. Neither streamgage documented any pulses similar to those at the Whitman streamgage. The overall magnitude of change at both sites is similar to or less than median grain sizes, and does not clearly exceed expected natural variability and measurement uncertainty. Cross sections at the 221st Avenue show an increase in the mean elevation of about $0.25 \mathrm{~m}$ over the study period, a result of increases in the elevation of the river-left gravel bar and infilling of the river-right pool.

Aerial photographs of the channel taken in autumn 2013 and again in the summer 2015 provided a potential way to identify locations where deposition of landslide sediment substantially altered channel configurations or bar extents. No disturbed reaches were identified and the overall character and configuration of the river did not appear to have changed markedly between the two dates. Particular attention was paid to reaches where hydraulic modeling indicated deposition might be likely (fig. 37), including the upstream end of the Whitman reach (rkm 28.5-30.5) and just upstream of the 221st Avenue Bridge (rkm 24-25.5) (figs. 42-43). Some minor increases were observed in the bar area at both sites, but there was little overall change the channel configuration or character. 

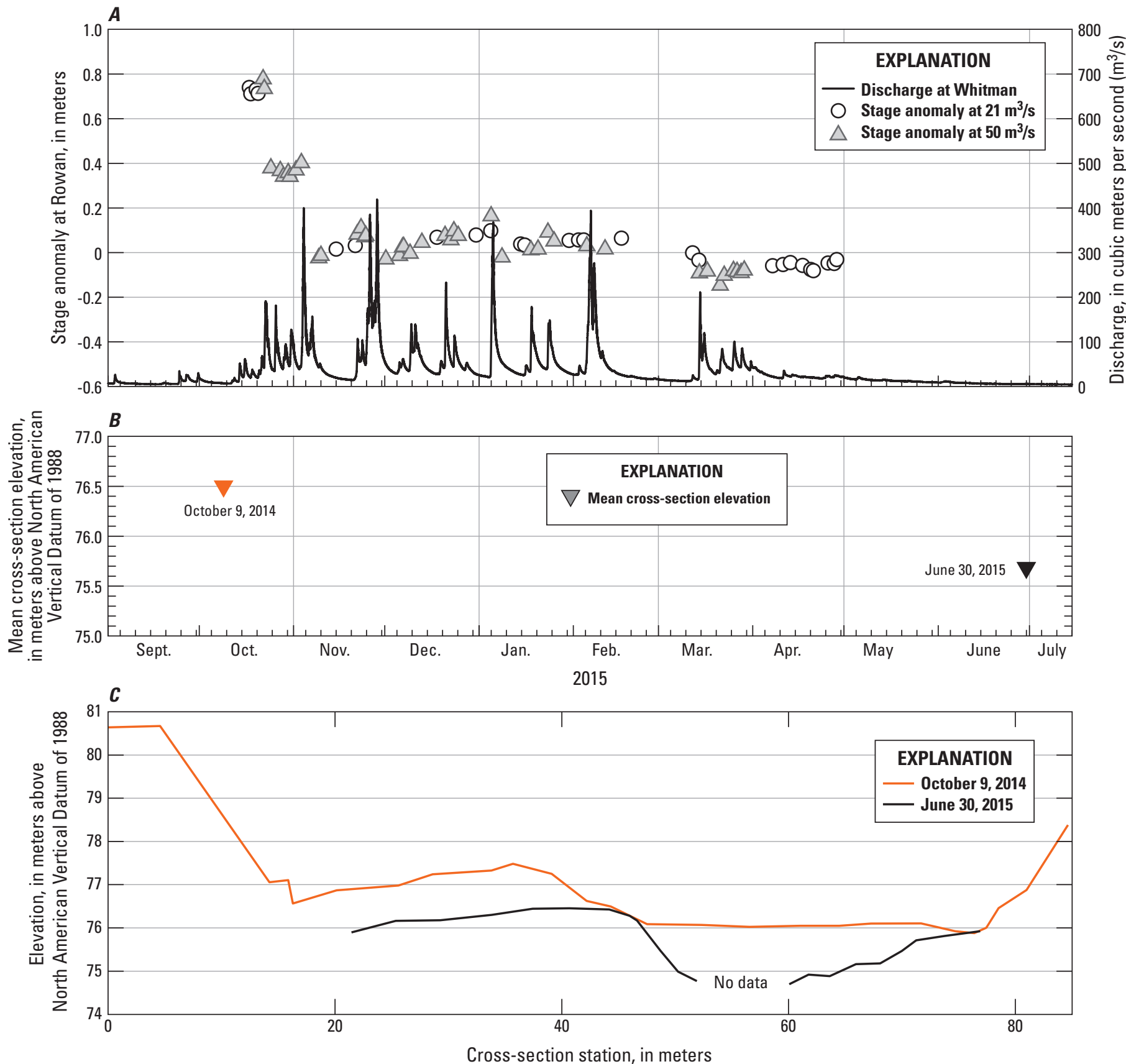

Figure 39. Streamgage analysis of $(A)$ relative change in stage for a fixed discharge, $(B)$ mean elevation of cross sections, and $(C)$ cross-section profiles of the North Fork Stillaguamish River at Rowan, Washington (USGS streamgage 12166240). High water velocities prevented obtaining thalweg depths for June 30, 2015. The absolute elevations in the streamgage analysis in $(A)$ were normalized by the mean value after December 1, 2014, to remove the difference in absolute stage between the two target discharges. Change is then relative to the mean elevation over that period, and does not imply any knowledge about the pre-landslide bed elevation. 

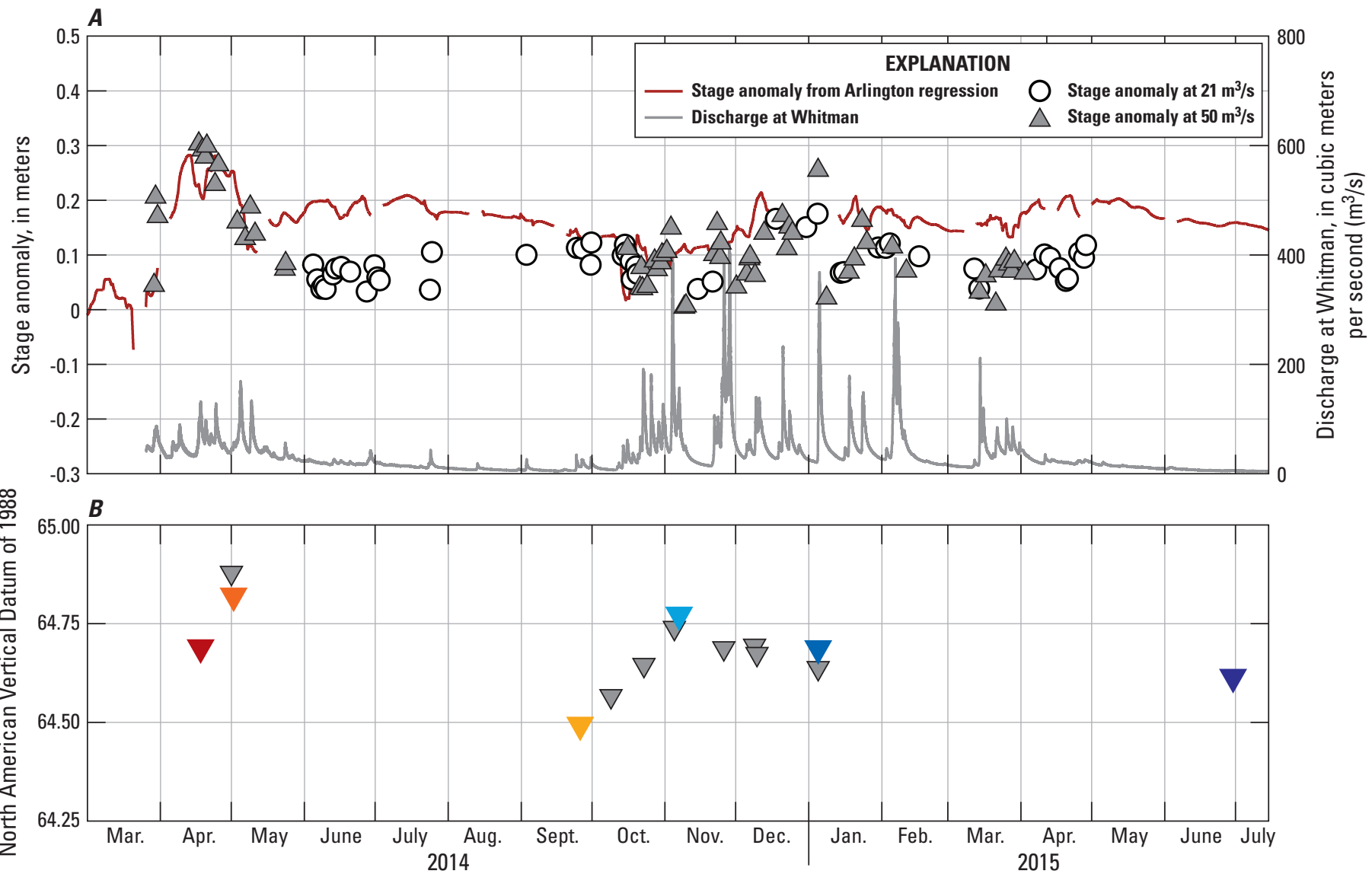

EXPLANATION
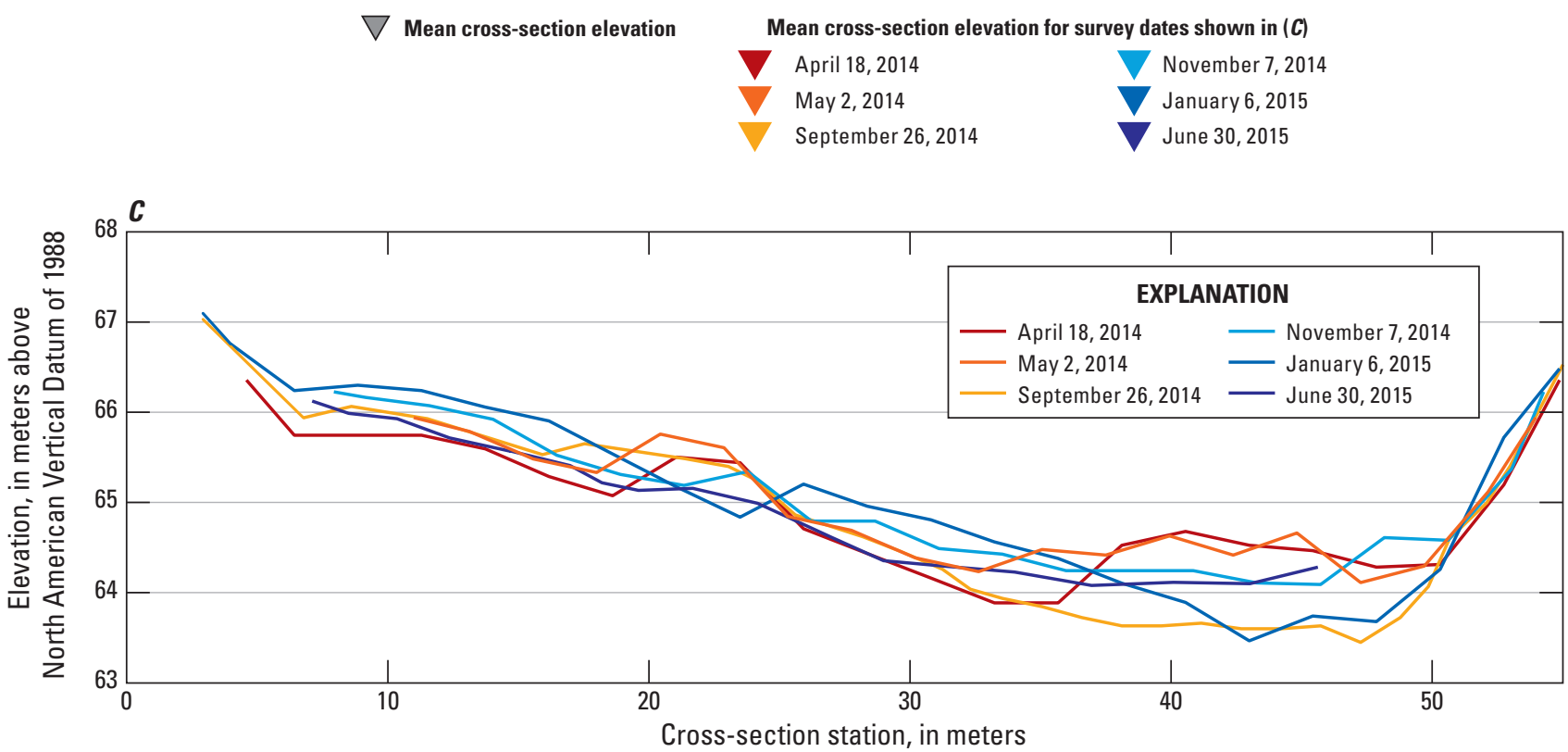

Figure 40. Streamgage analysis of $(A)$ relative change in stage for a fixed discharge, $(B)$ mean elevation of cross sections at site $(C)$ subset of available cross-section profiles at North Fork Stillaguamish River near Oso (Whitman), Washington (USGS streamgage 12166300). Residuals from the pre-landslide relation between stage at the Whitman streamgage and stage at the Arlington streamgage (USGS streamgage 12167000) are shown in $(A)$ and provide a second estimate of channel bed elevation change relative to conditions immediately prior to the landslide. 


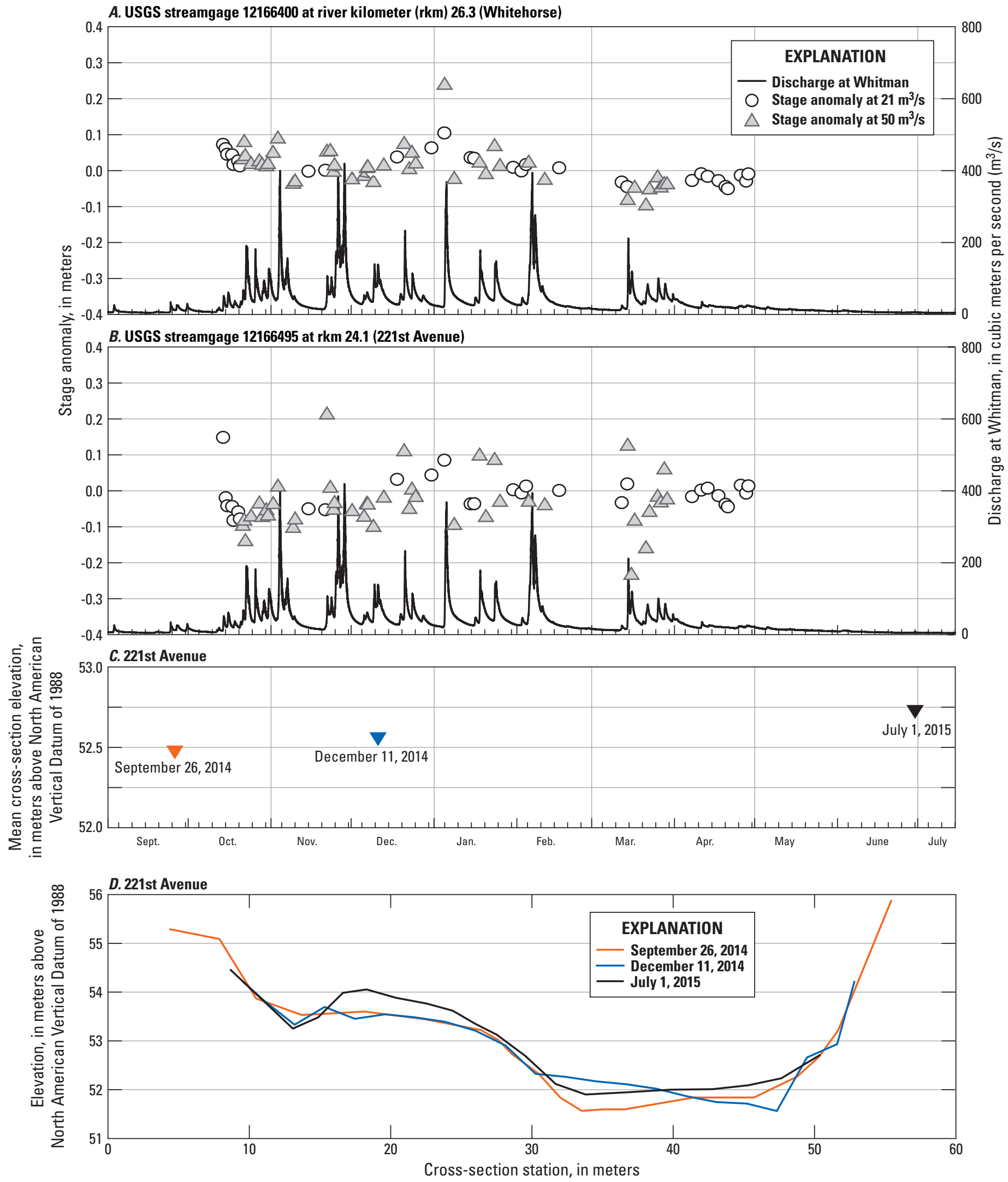

Figure 41. Streamgage analysis of relative change in stage for a fixed discharge at $(A)$ North Fork Stillaguamish River at Whitehorse Trail near Oso (Whitehorse; USGS streamgage 12166400) and (B) North Fork Stillaguamish River at Oso (221st Avenue; USGS streamgage 12166495); (C) mean elevation of cross sections; and $(D)$ cross-section profiles at 221st Avenue streamgage, Washington. No cross sections were measured at Whitehorse. 
September 10, $2013\left(11 \mathrm{~m}^{3} / \mathrm{s}\right)$

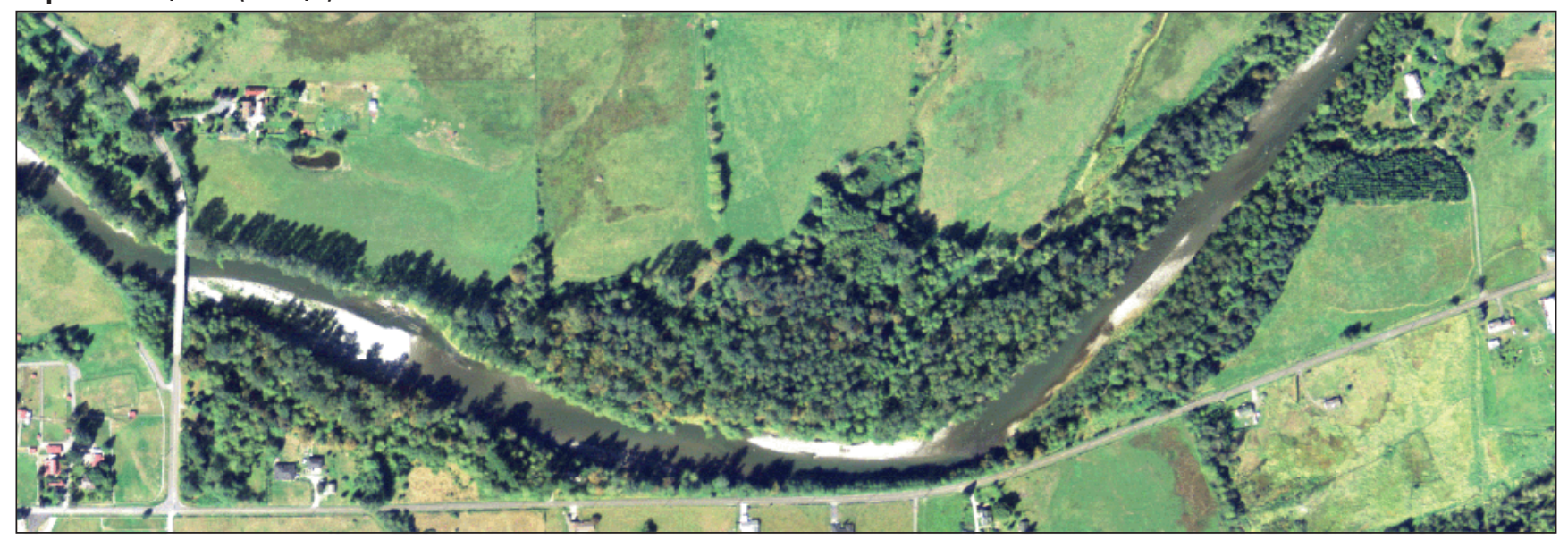

September $29,2015\left(10 \mathrm{~m}^{3} / \mathrm{s}\right)$

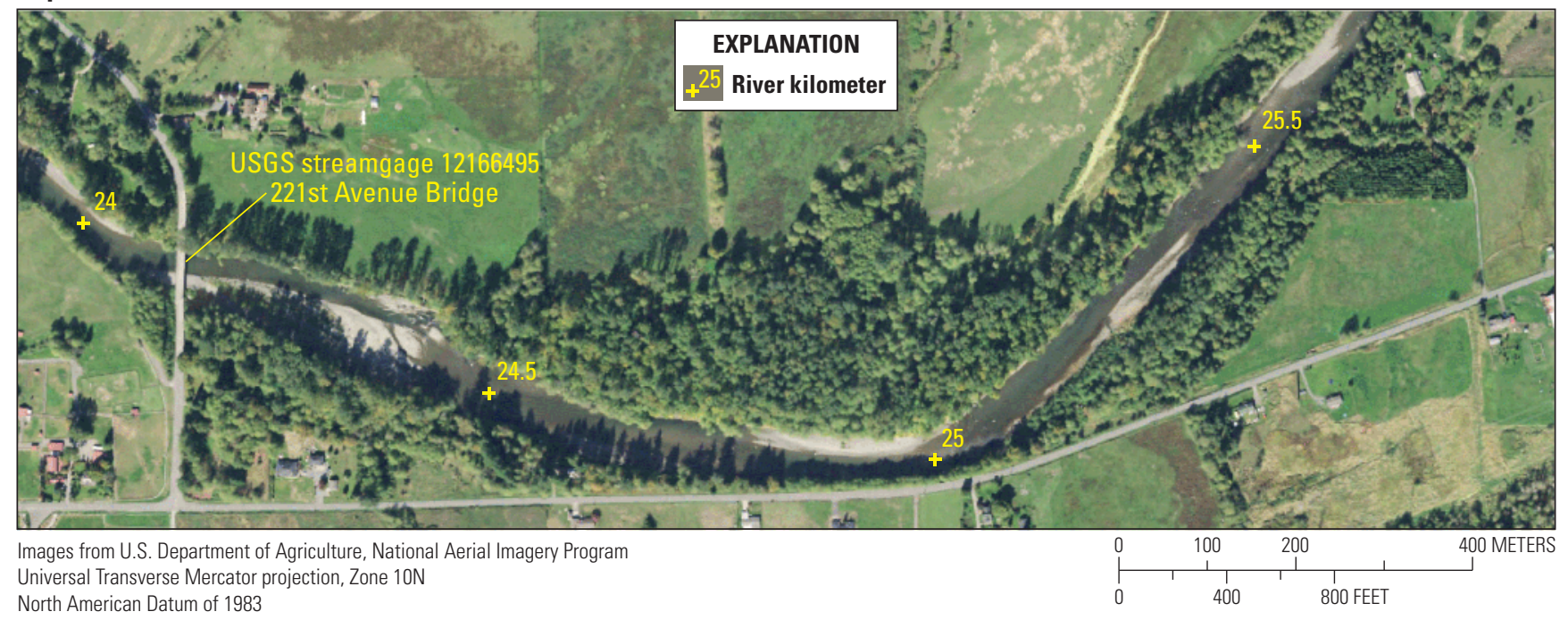

Figure 42. Repeat orthoimages showing change between river kilometers 24 and 25.5 at the North Fork Stillaguamish River, Washington, between September 2013 and September 2015. Sediment transport simulations indicated that transport capacities decreased sharply coming into this reach, suggesting that deposition of landslide sediment would be probable. Flow is from right to left. Discharges, in cubic meters per second $\left(\mathrm{m}^{3} / \mathrm{s}\right)$, are from North Fork Stillaguamish River near Arlington (USGS streamgage 12167000). 
September 10, $2013\left(11 \mathrm{~m}^{3} / \mathrm{s}\right)$

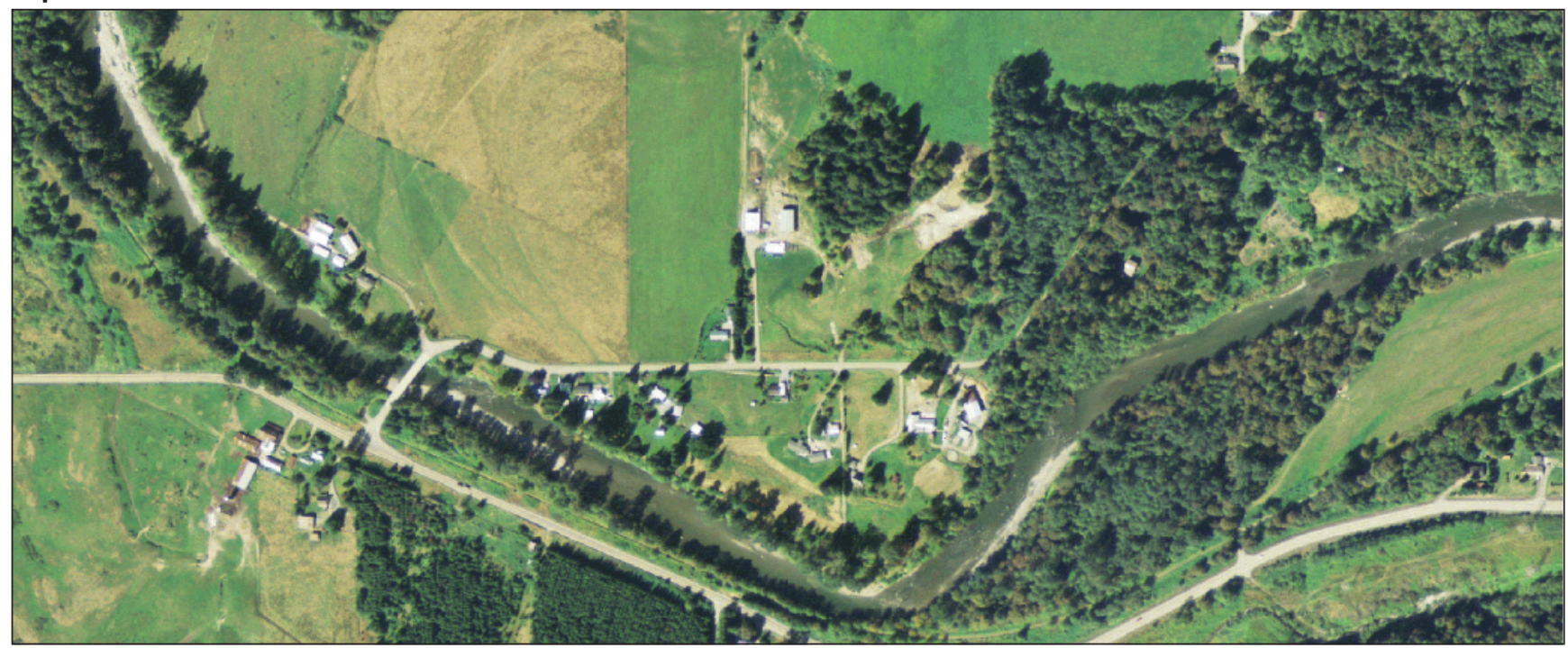

September $29,2015\left(10 \mathrm{~m}^{3} / \mathrm{s}\right)$

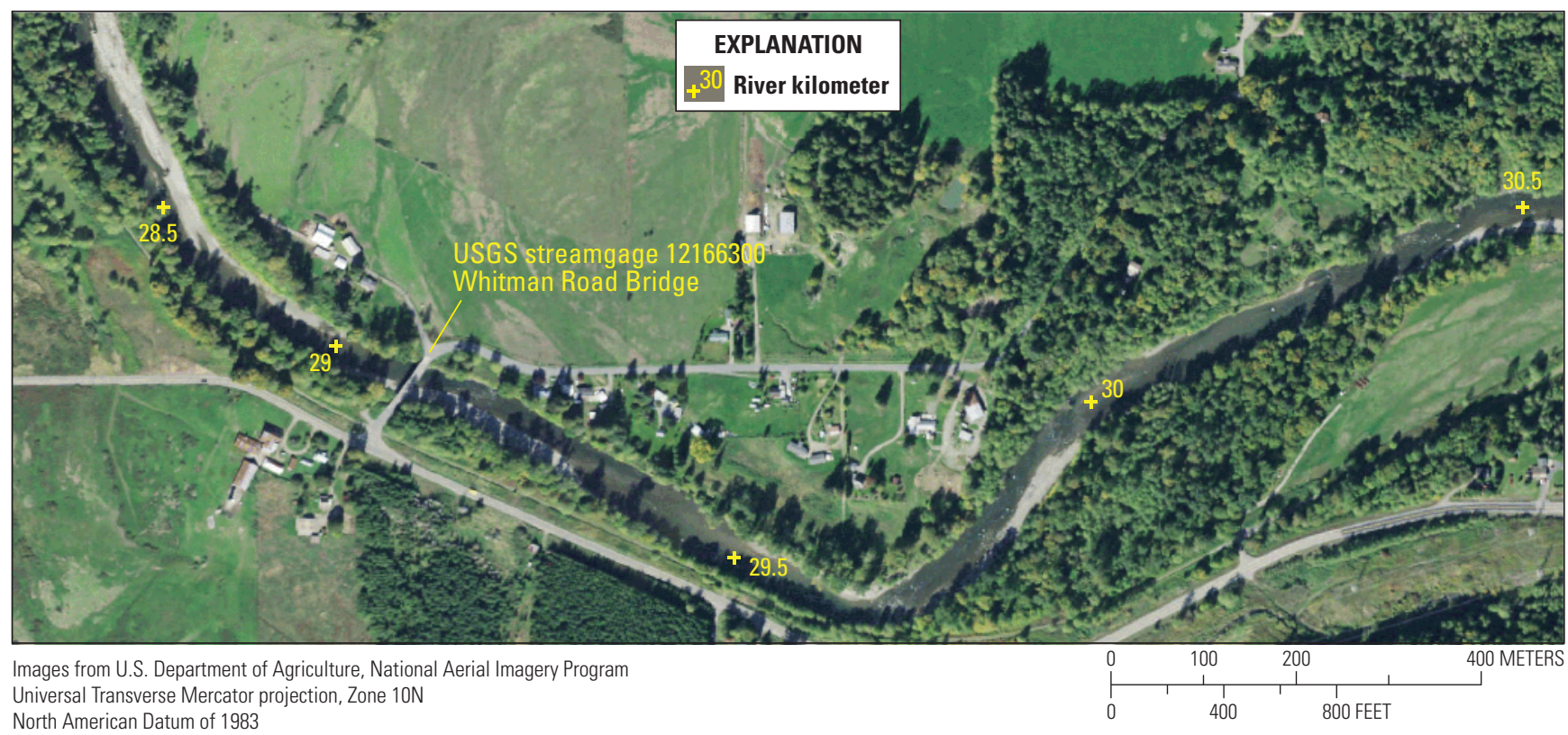

Figure 43. Repeat orthoimages showing change between river kilometers 28.5 and 30.5 at the North Fork Stillaguamish River, Washington, between September 2013 and September 2015. Sediment transport simulations indicated that transport capacities decreased sharply coming into this reach, suggesting that deposition of landslide sediment would be probable. Flow is from right to left. Discharges, in cubic meters per second $\left(\mathrm{m}^{3} / \mathrm{s}\right)$, are from North Fork Stillaguamish River near Arlington (USGS streamgage 12167000). 


\section{Changes in Surficial Grain Size}

After the landslide, surficial grain-size distributions downstream of the landslide showed a general fining trend, although the magnitude of that fining was similar in magnitude to inter-annual variability in measurements prior to the landslide (fig. 44). The fining was most notable in the Rowan and Whitman reaches just downstream of the landslide (figs. 44-45). At the Rowan streamgage bar, the site closest to the landslide, the fining trend was limited to 2014 and the site coarsened between 2014 and 2015. The overall fining predominantly was a result of an increase in the fraction of fine gravel (4-32 $\mathrm{mm})$ at sites. In contrast, the fraction of material less than $4 \mathrm{~mm}$ (sand and very fine gravel) did not vary in any clear systematic manner downstream of the landslide. Upstream of the landslide, samples collected predominantly near the C-Post Bridge show an increase in the fraction of material finer than $4 \mathrm{~mm}$ in 2014, and a subsequent decrease in 2015. The increase in fine material in 2014 is likely a result of deposition during the backwater conditions-the C-Post Bridge site in the weeks after the landslide. Gravel-size distributions upstream of the landslide were similar in 2014 to pre-landslide distributions, whereas a single sample collected in 2015 was finer than both pre-landslide and 2014 samples.
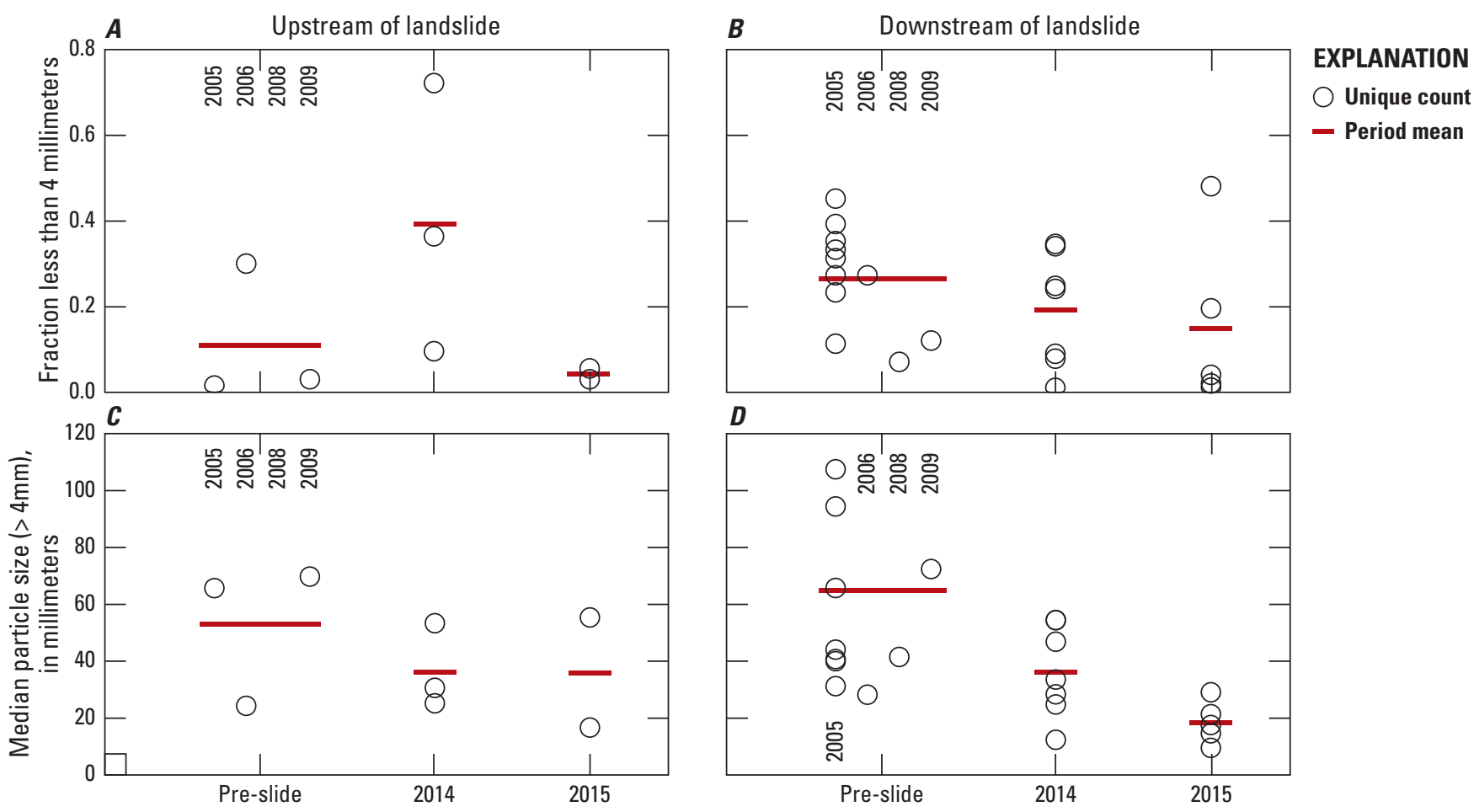

Figure 44. Surface particle counts and median gravel-particle sizes upstream and downstream of the SR 530 Landslide, North Fork Stillaguamish River, Washington. Fraction of particles finer than 4 millimeters at $(A)$ C-Post reach and $(B)$ Rowan and Whitman reaches, and median particle sizes, calculated for particle counts greater than 4 millimeters, for gravel at $(C)$ C-Post reach and $(D)$ Rowan and Whitman reaches. 
A. C-Post Bridge bar river kilometer (rkm) 34.80-34.67

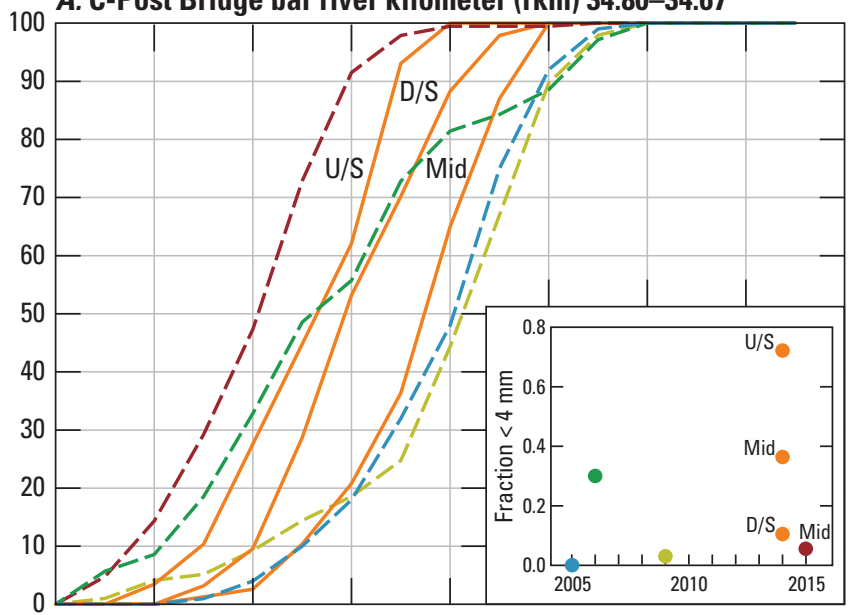

C. Rowan Island bar rkm 31.82

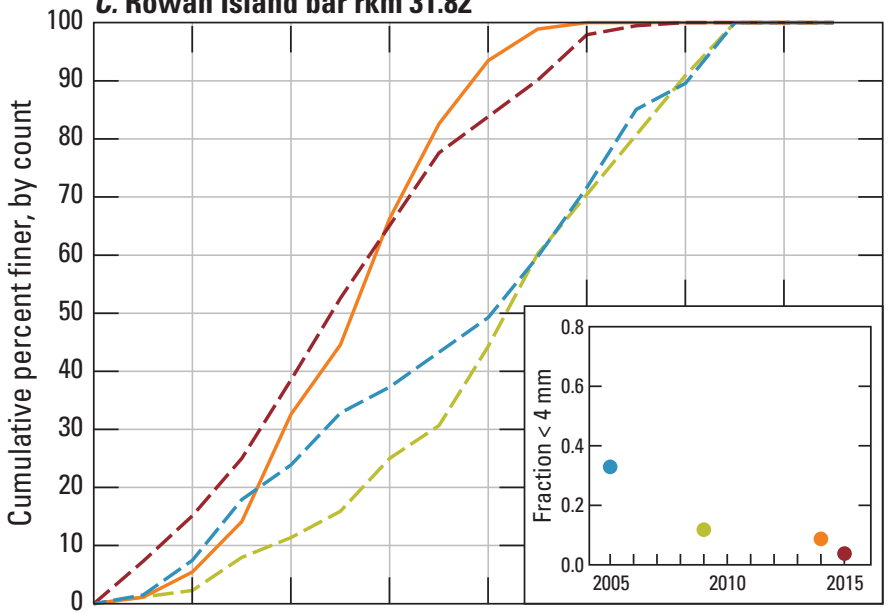

E. 221st Avenue bridge bar rkm 26.18-26.10

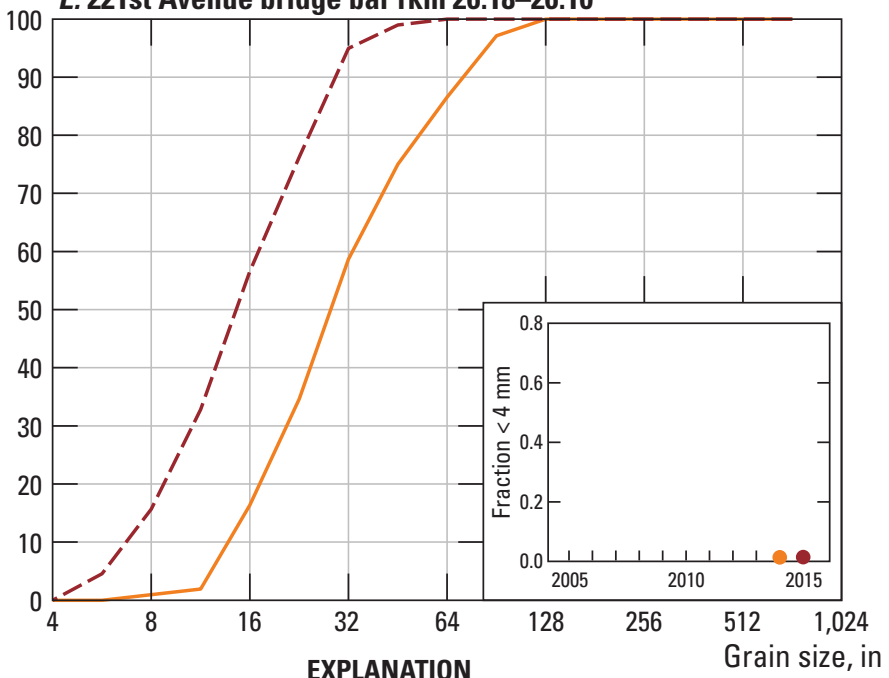

EXPLANATION
B. Rowan streamgage bar rkm 32.31-32.10

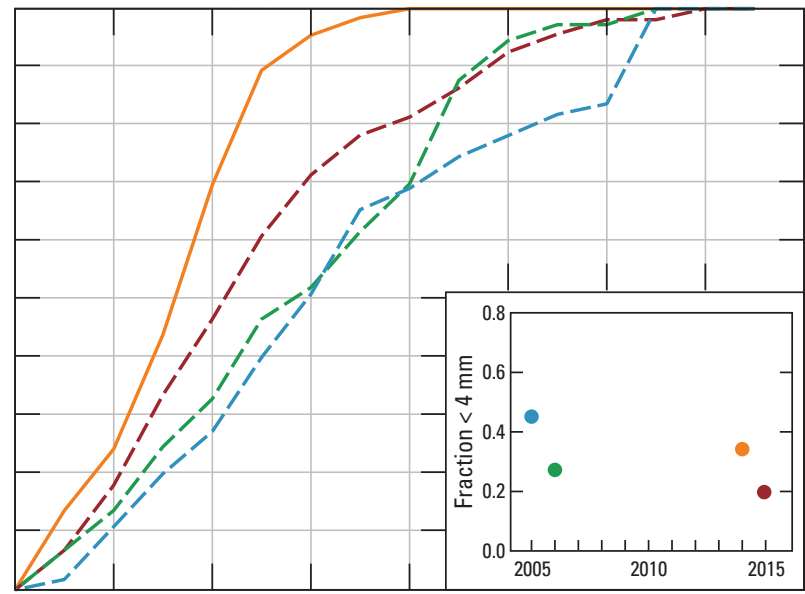

D. Whitman Road bridge bar rkm 29.21-29.10

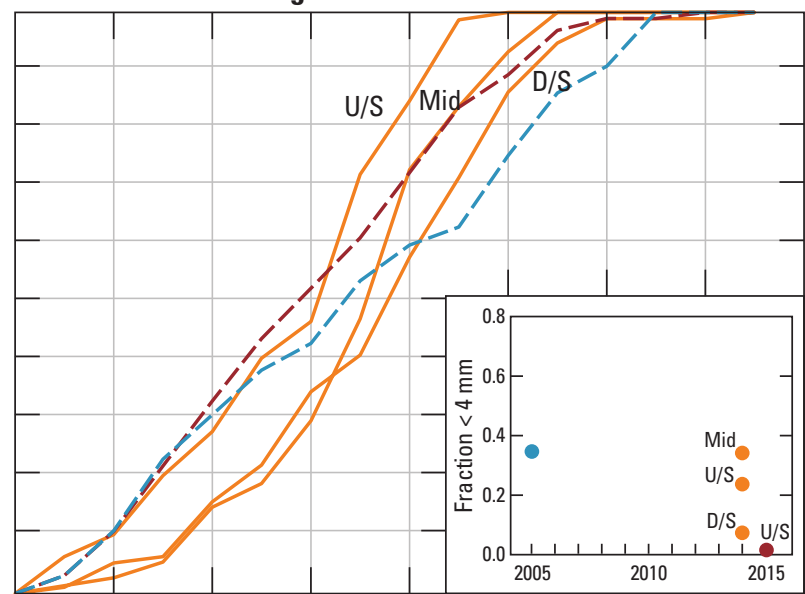

F. SR530 bridge near Cicero bar rkm 16.20-15.90

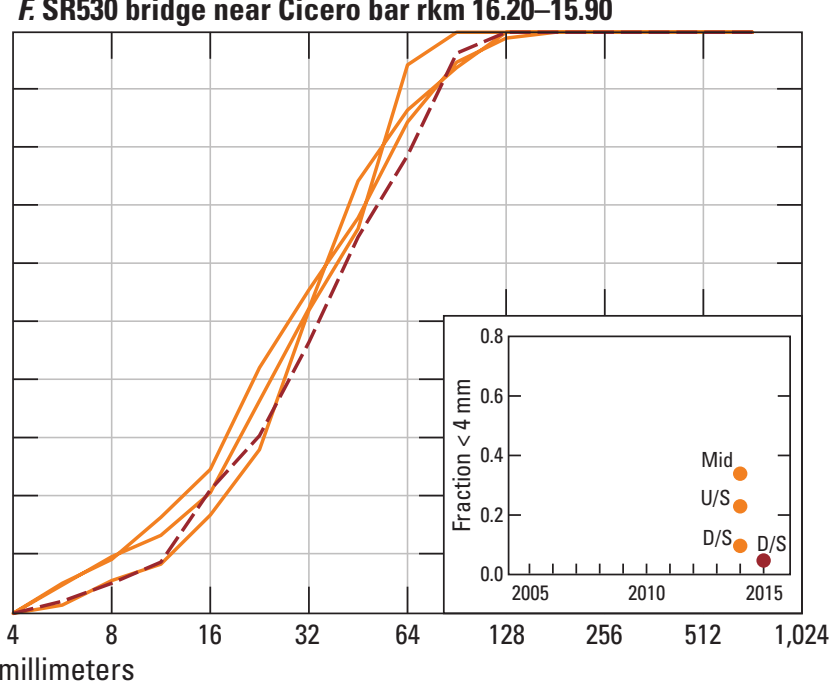

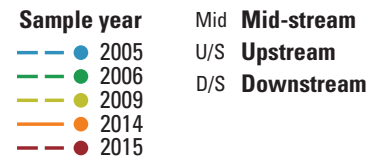

Figure 45. Surficial particle-size distributions for co-located sample sites in selected reaches along the North Fork Stillaguamish River, Washington. Curves show grain-size distributions truncated at 4 millimeters (mm), and reflect changes in gravel composition. Insets show variability in fraction of material finer than $4 \mathrm{~mm}$. At sites where multiple 2014 samples were collected along the length of an individual bar, the relative position of the samples are indicated as upstream, mid-stream, and downstream, and the specific site re-occupied in 2015. 


\section{Integrated Interpretation of Geomorphic Responses}

\section{Erosion of the Landslide Deposit}

The North Fork Stillaguamish River began to flow over the top of the deposit, initiating channelization at its downstream western edge, within about 25 hours of the landslide and incised a well-defined channel through the entire deposit, about $700 \mathrm{~m}$, within about 1 week (fig. 10). Subsequent vertical erosion lowered the new channel back to within $1 \mathrm{~m}$ of the pre-landslide profile over the next 2-3 months (fig. 12). To place those observations in context, observed geomorphic responses were compared with stream responses following the removal of constructed dams-the comparison is reasonable, because both scenarios involve the erosion of a valley-spanning sediment deposit by upstream propagation of a suddenly imposed knickpoint. In that context, knickpoint migration rates after the SR 530 Landslide would be considered typical. Knickpoints created by the removal of the 15-m high Marmot Dam in Oregon, and the 38-m high Condit Dam in Washington, migrated upstream more than $100 \mathrm{~m}$ in the first hour after dam removal, and both streams had migrated well over $400 \mathrm{~m}$ the first day. The knickpoint formed by the unplanned failure of a 38-m high dam in Taiwan migrated at least $2.5 \mathrm{~km}$ upstream in 3 months (Tullos and Wang, 2014). Vertical incision rates documented at the SR 530 Landslide (about $4 \mathrm{~m}$ in the first 2 weeks, and $7 \mathrm{~m}$ in the first several months), also are consistent with, if somewhat lower, that observations at the Marmot and Condit Dam sites. Incision of tens of meters was documented within the first year following the staged removals of the Glines Canyon and Elwha Dams in Washington. The re-establishment of a deeply inset channel through the SR 530 Landslide in a matter of months then is consistent with expectations drawn from these dam removals.

If the rates of knickpoint propagation and vertical incision through the SR 530 Landslide could be considered typical, the lateral erosion rates through the landslide were markedly less than lateral erosion rates documented in nearly all dam removals. Once the channel became inset within the landslide deposit, the height of the banks precluded avulsions, and lateral migration and widening occurred relatively slowly. About 13 percent of the total volume of material deposited on the valley floor was removed during the study period. For comparison, observations of erosion following the removal of constructed dams typically described rapid and persistent lateral erosion spanning much of the valley floor (Major and others, 2012; Tullos and Wang, 2014; Wilcox and others, 2014; Randle and others, 2015), and most studies have reported that 50 and 80 percent of the total volume of the dam deposit was evacuated within 18 months following removal (O’Connor and others, 2015).
The relatively slow rates of lateral erosion and low total evacuation rates of the SR 530 Landslide have several likely causes. The landslide deposit was substantially more clay-rich and cohesive than the vast majority of dam-held sediments. It is also likely that the compacted hillslope sediments were more consolidated than water-deposited dam sediments. The cohesive, compact character of the landslide deposit resulted in erosion-resistant banks that likely limited lateral channel migration and so total erosion rates. Ignoring differences in relative compaction, the idea that sediment composition is likely to influence sediment evacuation rates has support in the dam removal literature. Reservoirs composed of higher percentages of silt and clay tended to have lower evacuation rates (O'Connor and others, 2015), and observations following the Glines Canyon Dam determined that lateral migration rates slowed when the river fully incised through a sand and gravel layer and began eroding into a more clay rich layer of the deposit (Randle and others, 2015). The trends toward less complete evacuation of fine-grained deposits do have exceptions. The most notable was the rapid evacuation of the silt and sand-rich deposit stored behind the Condit Dam, where more than 1 million $\mathrm{m}^{3}$, about 60 percent of the deposit, was mobilized within 15 weeks (Wilcox and others, 2014). Erosion of the Condit deposit occurred primarily through shallow sliding of the saturated banks. Although the lacustrine material in SR 530 Landslide deposit would flow when saturated (fig. 17), the resulting failures were slow moving and did not result in rapid or substantial erosion. It is likely that the divergent responses of the Condit Dam sediments and the landslide deposit are a result of the higher clay content of the landslide deposit, its higher degree of compaction, and the lower saturation.

The relatively low evacuation rates of the SR 530 Landslide deposit may also be partly a result of the geometry of the landslide deposit, which had a much higher aspect ratio (wider in the cross-valley direction relative to its down-valley extent) than most dam sediment reservoirs. Because of the high aspect ratio, a large fraction of the landslide sediment could be accessed only through lateral erosion, which, as a result of the cohesive and compact nature of the deposit, has been occurring slowly.

It is difficult to determine if the pilot channel, constructed in mid- to late-April 2014, increased channel incision rates. Magirl, Keith, and others (2015) documented a clear acceleration in the lowering rate of the impoundment pool beginning mid-April 2014, coincident with the construction of the pilot channel. However, this acceleration also coincided with the highest peak flows since the landslide occurred, and as well as when the head of channelization had migrated upstream and intersected the impoundment lake, such that erosion began to directly lower the impounding lip of the deposit. Field examinations in summer 2014 determined that the initial channel alignment has incised several meters into unconsolidated fluvial deposits before becoming dewatered 
by construction of the pilot channel, and the outlet of the abandoned channel was at the same elevation of the current active channel (fig. 14). Based on this observation, it most likely that the river would have re-established a graded channel over the study period regardless of whether the pilot channel was constructed, but that the pilot channel plausibly contributed to the observed acceleration in impoundment lowering rates.

\section{Ambient and Landslide-Derived Fluvial Sediment Loads}

The delivery of about $820 \pm 80$ thousand metric tons of landslide material to the North Fork Stillaguamish River represented a measureable increase in sediment loads for the river system downstream of the landslide. The percentage increase above ambient sediment loads was most pronounced during the first several months following the landslide, when erosion was occurring rapidly, and discharges and ambient sediment loads were low. At the Whitman Road Bridge, $5 \mathrm{~km}$ downstream of the landslide, the parity of the estimates of sediment transport and estimates of erosion from the landslide in WY 2014-LS suggest that nearly all the estimated sediment load at that site was derived from the landslide over those initial months (table 9). This is corroborated by the minimal suspended-sediment load at the Swede Heaven site, upstream of the landslide, and the similarity of the grain-size distribution of eroded landslide material and the fluvial load at Whitman (fig. 46). Sediment measurements at Stanwood, near the mouth of the main-stem North Fork Stillaguamish River, indicate that about 50 percent of the WY 2014-LS suspended-sediment load at that site was likely derived from the landslide.

In WY 2015, the relative increase in sediment loads due to erosion of the landslide deposit was modest, particularly for the coarser fraction of material likely to move as bedload. The total bedload transport at Whitman was estimated to be $245 \pm 40$ thousand metric tons in WY 2015, a period when $40 \pm 5$ thousand metric tons of material coarser than $0.5 \mathrm{~mm}$ was eroded from the landslide. Assuming that all the eroded coarse landslide material reached Whitman during the study period, the landslide supplied a mass of coarse material that was about 20 percent of the ambient bedload. The assumption that landslide material traveling as bedload would reach the Whitman site relatively quickly is generally supported by bedload measurements in WY 2014-LS, when substantial amounts of sand and fine gravel, likely derived from the landslide, was collected in bedload measurements. If some fraction of the coarser eroded material remained in storage between the landslide and the Whitman streamgage, however, estimates herein would overestimate the fraction of the total bedload at Whitman that could be attributed to the landslide. The relative increase in coarse sediment load as a result of the landslide then would be somewhat less than 20 percent.

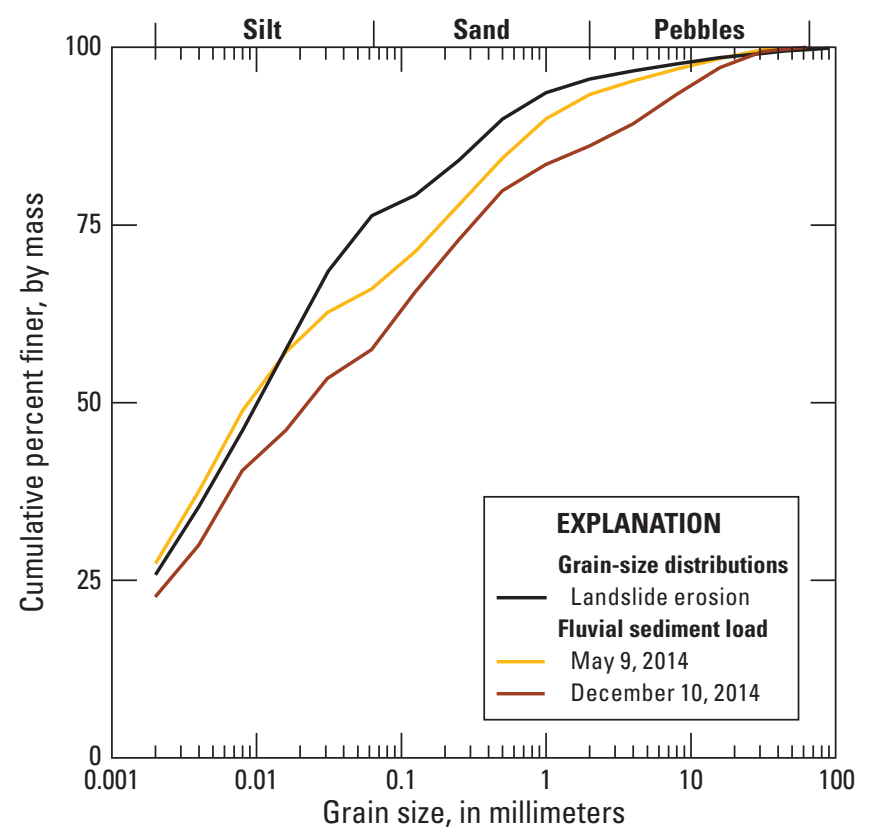

Figure 46. Grain-size distribution of sediment eroded from the landslide and full grain-size distribution of the fluvial sediment load at Whitman Road Bridge, North Fork Stillaguamish River, Washington. The grain-size distribution of the landslide sediment was estimated using the measured grain-size distributions for various facies, weighted by the areal percent of erosion that occurred in each facie over the entire study period. The fluvial sediment load grain-size distribution was based on concurrent measurements of suspended and bedload sediment. Discharge was 124 cubic meters per second $\left(\mathrm{m}^{3} / \mathrm{s}\right)$ on May 9, 2014, and 83 m³ on December 10, 2014.

The suspended-sediment load in WY 2015 at the Whitman site was estimated to be $560 \pm 70$ thousand metric tons, whereas the estimated erosion of landslide material finer than $0.5 \mathrm{~mm}$ was $360 \pm 35$ thousand metric tons (table 9). Under the reasonable assumption that all fine material eroded from the landslide transited past Whitman, it was estimated that landslide material made up about 65 percent of the measured suspended-sediment load, and that the delivery of landslide material increased suspended-sediment loads about 180 percent greater than the implied ambient load of $200 \pm 80$ thousand metric tons. This estimate of the ambient suspended-sediment load, based on a comparison of the Whitman sediment load and erosion from the landslide, is indistinguishable within uncertainty from the estimate of $160 \pm 90$ thousand metric tons obtained at the Swede Heaven streamgage upstream of the landslide. However, the relatively higher estimate of ambient loads at Whitman may plausibly reflect the additional sediment inputs from intervening tributaries, including Rollins and Montague Creeks (fig. 4). 
The grain-size distribution of the combined bedload and suspended-sediment load coarsened in a paired set of samples collected December 10, 2015, both relative to an earlier paired sample and the grain-size distribution of the landslide (figs. 30 and 46). This coarsening likely is a result of the greater contribution of ambient sediment to the measured sediment load, which is likely coarser than the clay and silt-rich landslide deposit.

These observations of sediment transport indicate that, although the landslide resulted in a measurable increase in sediment loads, the North Fork Stillaguamish River was able to transport that material downstream efficiently, even during the modest discharges of WY 2014-LS. Generally, finer material was mobilized more completely and farther downstream. Most notably, suspended sediment monitoring at Stanwood indicate that about 70 percent of eroded landslide material could be accounted for in the suspended-sediment load near the mouth of the North Fork Stillaguamish River, indicating that most of the eroded landslide material had already exited the entire Stillaguamish River Basin by the end of this study (fig. 47). The estimate of landslide material at Stanwood also closely matched, in terms of timing and quantity, estimates of landslide erosion, indicating that the lag between initial entrainment and arrival at Stanwood was consistently short and not likely to exceed several weeks. Although sand and gravel from the landslide would be expected to travel slower than the suspended-sediment load, the bedload measurements made at Whitman in WY 2014 indicate that the river transported a substantial amount of the supplied sand and fine gravel over $5 \mathrm{~km}$ within several months, even though discharges rarely exceeded 25 percent of a 2-year flood (0.5 AEP). There was some amount of landslide sediment storage just downstream of the landslide at the end of WY 2014, indicating that not all of the eroded material was mobilized rapidly downstream. However, most of that stored material was remobilized during the first two winter storms in WY 2015, and no additional deposition of material was detected. This indicates that moderate flows ( 50 percent of the $0.5 \mathrm{AEP}$ to $0.5 \mathrm{AEP}$ ) were sufficiently competent to transport the combined sediment load from ambient upstream sources, continued erosion of the landslide deposit, and the re-entrained material stored just downstream of the landslide deposit.

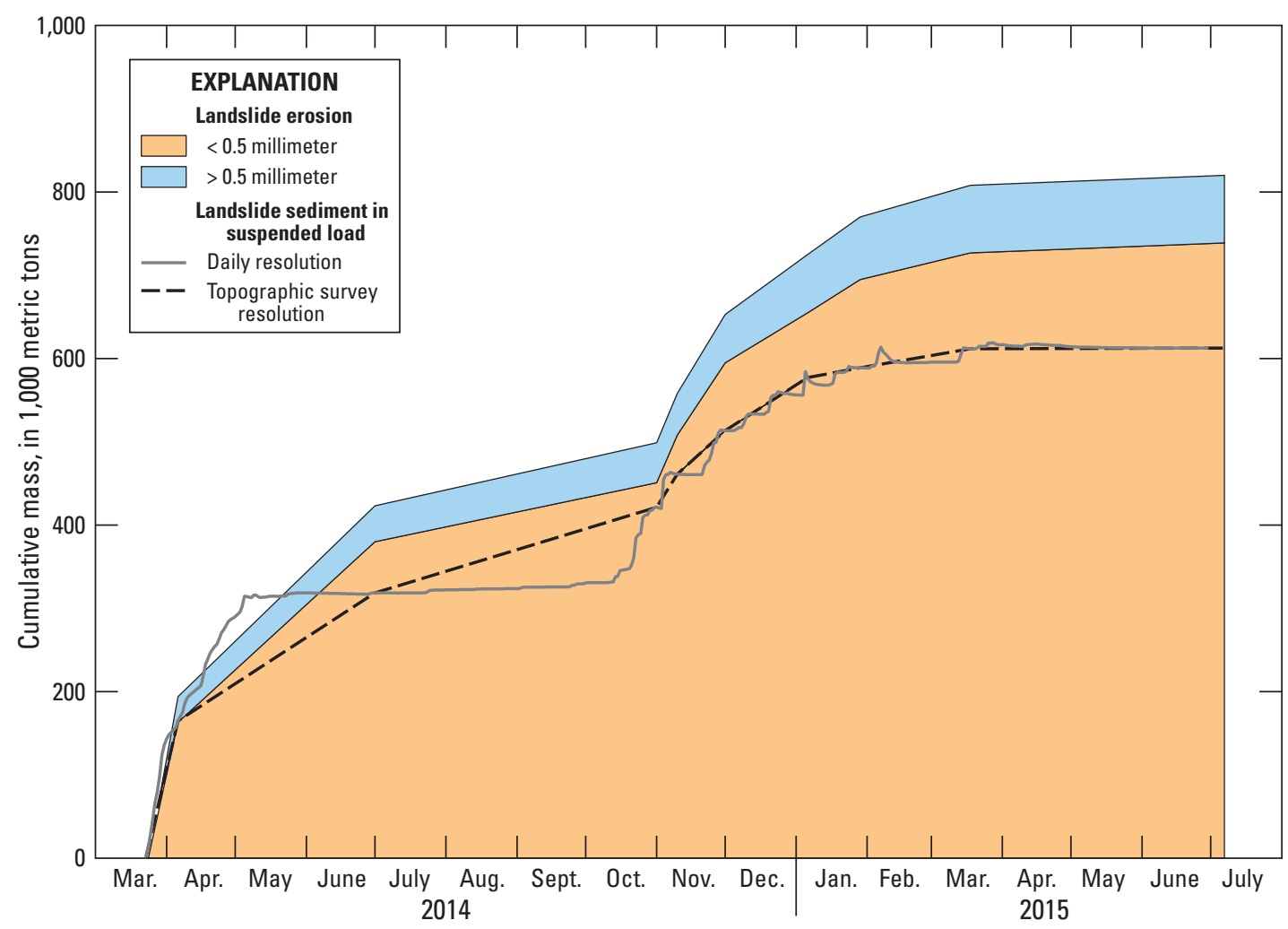

Figure 47. Cumulative eroded landslide mass based on repeat topography compared against estimated landslide sediment in suspended-sediment load at North Fork Stillaguamish River near Stanwood, Washington (Stanwood; USGS streamgage 12170300). Periods in which the estimated mass of landslide sediment at Stanwood appears to exceed the mass of landslide sediment eroded are artifacts of the limited temporal resolution of the repeat topographic surveys; subsampling the time series of cumulative landslide sediment at Stanwood to only those days on which topographic surveys were collected removes this artifact. The daily time-step record of landslide sediment at Stanwood likely provides a more realistic record of when erosion over different survey intervals actually occurred. 


\section{Downstream Geomorphic Responses}

The delivery of predominantly fine-grained sediment from the SR 530 Landslide resulted in downstream geomorphic responses that were modest in magnitude and relatively short-lived. The two most pronounced responses were the wedge of aggradation just downstream of the landslide (figs. 11 and 38) and the $0.3 \mathrm{~m}$ pulse of aggradation at the Whitman Road streamgage (fig. 40). In both cases, peak geomorphic response and aggradation occurred within weeks of the landslide, and both sites had transitioned into a recovery phase by the end of May 2014. Of the four streamgage sites monitored in WY 2015, the only appreciable net vertical channel change was the incision at the Rowan streamgage, which represented the re-entrainment of landslide sediment deposited before the streamgage was installed. Although the streamgage analysis only provides measures of change at individual points, the results are corroborated by qualitative comparisons of aerial photographs of the North Fork Stillaguamish River taken just prior to the landslide and in late summer 2015, which showed little to no change in bare-gravel extents or configuration, including the reach just downstream of the landslide (figs. 38, 42, and 43). A fining of surface-sediment gravel distributions was observed downstream of the landslide that was most significant at the sites closest to the landslide, although the magnitude of the change is not substantially larger than inter-annual variability seen prior to the landslide (figs. 44-45).

The relatively modest downstream geomorphic response to the SR 530 Landslide is consistent with expectations drawn from recent dam removals, based on the magnitude of the landslide-derived sediment loads in comparison to the ambient sediment loads, and the fine-grained nature of that delivered sediment. Over the 18 months of study, the SR 530 Landslide delivered about 1.5-2 times the estimated ambient sediment load at the Whitman streamgage site, primarily due to the substantial increase in suspended-sediment loads. Downstream channel responses to dam removals that deliver less than about three to four times the local mean annual sediment load within the first year typically have been modest, and primarily localized to the first several kilometers downstream of the breach site (Major and others, 2012; Bountry and others, 2013; Wilcox and others, 2014; East and others, 2015; O’Connor and others, 2015). Moreover, substantial geomorphic responses downstream of dam removals have been related primarily to the deposition of coarser gravel moving as bedload. In contrast, rivers have been able to transport substantial quantities of suspended material and sand moving as bedload following dam removals with only modest downstream geomorphic effects, even during low or moderate discharges (Grant and Lewis, 2015). In an extreme case, the sudden removal of the Condit Dam rapidly delivered about 70 times the pre-dam annual sediment load in a matter of days, but downstream aggradation of 1-2 m peaked within a week following the dam removal, and had re-incised back to pre-removal elevations within 2 weeks (Wilcox and others, 2014). The SR 530 Landslide was substantially smaller than the sediment from Condit Dam in terms of relative sediment delivery, and had an even finer sediment distribution dominated by silt and clay. The muted downstream response to the SR 530 Landslide then seems consistent with expectations for the delivery of a sediment input equal to several times the annual load and composed of predominantly fine-grained material that travels in suspension.

\section{Transport Modeling Results}

Bedload transport modeling was used to identify reaches in which the deposition of landslide sediment would be most likely to occur. However, the Wilcock and Crowe (2003) equation, which provided the best fit to bedload measurements at Whitman Road, suggested that transport capacities integrated over the study period were several times larger than the supply of landslide sediment over all downstream reaches, making it unlikely that any substantial deposition would occur. That presumption was consistent with observational results for this study. Although the modeling efforts, and specifically the Wilock and Crowe (2003) equation results, seem to be validated at the broadest level, the relative absence of any calculated or measured deposition makes it difficult to assess whether the finer scale estimates of variations in transport capacity are reasonable. Additionally, the calculations from the Wilcock and Crowe (2003) equation upstream of the landslide would suggest that bedload made up about 75 percent of the total load at the Swede Heaven streamgage site (fig. 37). This is unexpectedly high; a bedload fraction of between 15 and 30 percent is more typical for larger gravel-bedded rivers (Turowski and others, 2010). Using bedload to total load partitioning rates of between 15 and 30 percent and the estimate of suspended-sediment transport at Swede Heaven, estimated bedload transport rates at Swede Heaven closely match calculated transport capacities from the Parker (1990a, 1990b) and Recking (2013) equations (fig. 37). It is then plausible that the Parker (1990a, 1990b) and Recking (2013) equations provide reasonable estimates of gravel transport in the North Fork Stillaguamish River under typical channel conditions that are not influenced by substantial landslide inputs.

\section{Anticipated Trajectory}

\section{Landslide Channel and Sediment Delivery}

The efficiency of erosion of the landslide deposit, quantified as the volume of sediment removed per unit discharge, decreased sharply in the first months after the landslide, and continued to decrease monotonically over the remainder of the study period (fig. 20). This asymptotic recovery trend is typical of channel responses following large 
sediment inputs (Simon and Rinaldi, 2006; O’Connor and others, 2015), and baring any further hillslope activity, erosion efficiency likely will continue to decrease in the future. This implies decreasing rates of channel widening, lateral migration, and overall sediment delivery. Therefore, although erosion of the SR 530 Landslide will continue to deliver sediment to the river, it will do so at rates lower than observed in WY 2015. As an estimate of potential WY 2016 erosion, an exact repeat of the WY 2015 hydrograph operating with an erosion efficiency equal to that observed in the latter part of the study period, between January 6 and July 7, 2015, would produce an additional $110,000 \mathrm{~m}^{3}$ of erosion, or approximately 45 percent of observed erosion during WY 2015.

During the study period, areas of focused erosion and the direction of lateral channel migration were primarily dictated by the meander pattern through the new channel, and that meander pattern has been stable (fig. 15). Extrapolating forward from the observed spatial patterns of erosion, continued erosion is likely to mobilize most lacustrine material, a lesser fraction of outwash material and only minimal amounts of till (fig. 16). The grain-size distribution of the delivered sediment over the following years likely will be similar to distributions observed in WY 2015, which was primarily composed of clay, silt, and fine sand (fig. 19). The delivered sediment load may coarsen if and when continued westward migration of the meander bend at the eastern edge of the deposit provides the river more access to expanses of sandy outwash material. However, outwash is still predominantly composed of fine sand and the coarsening would be modest (fig. 18).

Over longer time scales, removal of a large fraction of the landslide material is likely to occur slowly. As an absolute lower estimate, the continued erosion of $110,000 \mathrm{~m}^{3} / \mathrm{yr}$, the erosion estimated to occur in WY 2016, would remove the entire 3.4 million $\mathrm{m}^{3}$ of material on the valley floor in about 30 years. This estimate assumes that erosion efficiencies do not decrease further and that the river continues to erode new expanses of the landslide deposit every year. Neither assumption is likely to be met; it is more likely that a substantial fraction of the SR 530 Landslide deposit will remain on the valley floor in long-term storage. The clearest evidence for this is the pervasive presence of large landslide deposits between 500 and 10,000 years old along the adjacent valley floor (LaHusen and others, 2015). Most notably, the morphologically and compositionally comparable Rowan Landslide deposit (fig. 2) has continued to confine the river within a narrow and steep-walled reach despite $500-600$ years of erosion. The Rowan reach, at its narrowest, was similar in width to the SR 530 Landslide reach as of the summer of 2015. This suggests that, to the degree that the Rowan reach is a reasonable guide to the future state of the SR 530 Landslide channel reach, the new channel through the SR 530 Landslide already may be close to a quasi-equilibrium form. This comparison may or may not be exact-the Rowan reach is bounded on one side by the bedrock valley wall, whereas the SR 530 Landslide reach sits entirely within the center of landslide deposit. Regardless, site observations indicate that the removal of the remaining 3.4 million $\mathrm{m}^{3}$ of landslide material on the valley floor is likely to be a process that occurs over centennial, if not longer, timescales.

\section{Downstream Geomorphic Responses}

The observed downstream geomorphic responses to the SR 530 Landslide predominantly occurred within the first few months following the landslide, when initial channelization was progressing rapidly and discharges and transport capacities were relatively low. Observed aggradation downstream of the landslide was modest in magnitude and most of the affected reaches had recovered by the end of WY 2014-LS. The only substantial channel change in observed WY 2015 was the continued re-incision of landslide material stored just downstream of the deposit, with all other locations showing stability. The North Fork Stillaguamish was then fully able to transport the supplied landslide material during a normal range of flows. Given the expectation that rates of erosions will continue to decrease, it is not likely that the SR 530 Landslide will have any effects on the downstream morphology of the North Fork Stillaguamish River sufficient enough to alter flood stages.

\section{Conclusions}

The erosion of the SR 530 Landslide deposit delivered a volume of sediment to the North Fork Stillaguamish River equal to about two times the ambient sediment load. However, downstream geomorphic responses to that sediment input have been modest and largely short-lived, and, as of summer 2015, there is little evidence that downstream reaches have been modified in any significant or persistent way by the passage of that sediment. This modest response was a result of the fine-grained nature of the landslide deposit, which predominantly delivered silt, clay, and fine sand that was efficiently entrained downstream as suspended sediment. The rate that sediment was delivered was likely slowed by the cohesive nature of this sediment, which limited channel erosion and migration through the landslide deposit.

The rate of sediment delivery from the landslide decreased over the study period as the channel evolved toward a quasi-equilibrium form. Baring continued hillslope activity, sediment delivery rates are anticipated to continue to decrease such that sediment delivery from the landslide over future years is likely to be modest in comparison to the first 18 months after the landslide. Given the resilience of downstream reaches during the first 18 months, future erosion and sediment delivery are not anticipated to have any significant effects on downstream reach-scale channel morphology or associated flood hazards. 


\section{Acknowledgments}

The Federal Emergency Management Agency and Snohomish County, Washington, provided funding for the study. Andrew Ritchie, National Park Service, provided guidance on the Structure-from-Motion photogrammetry methods. Dan, Dave, and Drew Porter of BCI Contracting, Inc., provided data on the pilot-channel excavation. Jody Brown and Jason Griffith of the Stillaguamish Tribe of Indians provided particle-size data collected before the 2014 landslide. Zach Brown of Snohomish County provided the initial HEC-RAS model used for the study and provided guidance regarding its development. JoJo Mangano, Heather Bervid, James White, Norm Buccola, Marc Stewart, Rick Kittleson, Clay Weathers, Dave Piatt, Heather Bragg, Kurt Spicer, Tami Christianson, Andrew Spanjer, Steve Sissel, Norm Peterson, Craig Senter, and Theresa Olsen all provided help with data collection and processing. Jim O'Connor, Jon Major, Kathy Conn, and John Risley of the U.S. Geological Survey, provided invaluable feedback and comments that substantially improved this report.

\section{References Cited}

Anderson, C.W., Fisk, G.G., Gartner, J.W., Glysson, G.D., Gooding, D.J., Gray, J.R., Hornewer, N.J., Larsen, M.C., Macy, J.P., Rasmussen, P.P., Wright, S.A., and Ziegler, A.C., 2010, Surrogate technologies for monitoring suspendedsediment transport in rivers-Turbidity (bulk optics), in Gray, J.R., and Gartner, J.W., eds., Sedimentology of aqueous systems: London, Wiley-Blackwell, p. 3-45.

Anderson, S.W., 2017, Digital elevation models of the State Route 530 Landslide near Oso, Washington, July 2014 to July 2015: U.S. Geological Survey data release, https://doi. org/10.5066/F7T72FPK.

Anderson, S.W, Curran, C.A, and Grossman, E.E., 2017, Suspended-sediment concentration and loads in the lower Stillaguamish River, water years 2014-2015: U.S. Geological Survey Open-File Report 2017-1066, https:// doi.org/ofr20171066.

Beechie, T.J., Collins, B.D., and Pess, G.R., 2001, Holocene and recent geomorphic processes, land use, and salmonid habitat in two north Puget Sound river basins, in Dorava, J.M., Montgomery, D.R., Palcsak, B.B., and Fitzpatrick, F.A. eds., Geomorphic processes and riverine habitat (Water Science and Application Volume 4): San Francisco, American Geophysical Union, p. 37-54.
Bountry, J.A., Lai, Y.G., and Randle, T.J., 2013, Sediment impacts from the savage rapids dam removal, Rogue River, Oregon: Reviews in Engineering Geology, 21, p. 93-104.

Bunte, Kristin, and Abt, S.R., 2001, Sampling surface and subsurface particle-size distributions in wadable gravel and cobble-bed streams for analyses in sediment transport, hydraulics, and stream-bed monitoring: U.S. Forest Service, General Technical Report RMRS-GTR-74, 428 p.

Cohn, T.A., 2005, Estimating contaminant loads in riversAn application of adjusted maximum likelihood to type 1 censored data: Water Resources Research, v. 41, no. 7, 13 p., accessed February 2016, at http://onlinelibrary.wiley. com/doi/10.1029/2004WR003833/epdf.

Cohn, T.A., Delong, L.L., Gilroy, E.J., Hirsch, R.M., and Wells, D.K., 1989, Estimating constituent loads: Water Resources Research, v. 25, no. 5, p. 937-942.

Daniels, M.D., and McCusker, M.H., 2010, Operator bias characterizing stream substrates using Wolman pebble counts with a standard measurement template: Geomorphology, v. 115, no. 1, p. 194-198.

Davis, B., 2006, FISP's suite of Federally approved suspended-sediment/water quality collapsible-bag samplers: Proceedings of the Eighth Federal Interagency Sedimentation Conference (8thFISC), April 2-6, 2006, Reno, Nevada, p. 296-303.

Dragovich, J.D., Stanton, B.W., Lingley, W.S., Jr, Griesel, G.A., and Polenz, Michael, 2003, Geologic map of the Oso 7.5-minute quadrangle, Skagit and Snohomish Counties, Washington: Washington Division of Geology and Earth Resources Open-File Report 11.

Duan, N., 1983, Smearing estimate-A nonparametric retransformation method: Journal of the American Statistical Association, v. 78, no. 383, p. 605-610.

East, A.E., Pess, G.R., Bountry, J.A., Magirl, C.S., Ritchie, A.C., Logan, J.B., Randle, T.J., Mastin, M.C., Minear, J.T., Duda, J.J., and Liermann, M.C., 2015, Large-scale dam removal on the Elwha River, Washington, USA-River channel and floodplain geomorphic change: Geomorphology, v. 228, p. 765-786.

Edwards, T.K., and Glysson, G.D., 1999, Field methods for measurement of fluvial sediment: U.S. Geological Survey Techniques of Water-Resources Investigations, book 3, chap. C2, 89 p.

Eide, Jerry, 1990, A 48-year sediment budget (1942-1989) for Deer Creek Basin, Washington: Bellingham, Wash., Western Washington University, Master’s thesis, 122 p. 
Eisenhauer, J.G., 2003, Regression through the origin: Teaching Statistics, v. 25, no. 3, p. 76-80.

Fonstad, M.A., Dietrich, J.T., Courville, B.C., Jensen, J.L., and Carbonneau, P.E., 2013, Topographic structure from motion-A new development in photogrammetric measurement: Earth Surface Processes and Landforms, v. 38, no. 4, p. 421-430.

Gilroy, E.J., Hirsch, R.M., and Cohn, T.A., 1990, Mean square error of regression-based constituent transport estimates: Water Resources Research, v. 26, no. 9, p. 2,069-2,077.

Gomez, B., and Church, M., 1989, An assessment of bedload sediment transport formulae for gravel bed rivers: Water Resources Research, v. 25, no. 6, p. 1,161-1,186.

Grant, G.E., and Lewis, S.L., 2015, The remains of the damWhat have we learned from 15 years of US dam removals?, in Lollino, G., Arattano, M., Rinaldi, M., Giustolisi, O., Marechal, J.-C., and Grant, G.E., eds., Engineering geology for society and territory-Volume 3: Springer International Publishing, p. 31-35.

Haugerud, R.A., 2014, Preliminary interpretation of pre-2014 landslide deposits in the vicinity of Oso, Washington: U.S. Geological Survey Open-File Report 2014-1065, 4 p., accessed September 2015, at http://dx.doi.org/10.3133/ ofr20141065.

Iverson, R.M., George, D.L., Allstadt, K., Reid, M.E., Collins, B.D., Vallance, J.W., Schilling, S.P., Godt, J.W., Cannon, C.M., Magirl, C.S., Baum, R.L., Coe, J.A., Schulz, W.H., and Bower, J.B., 2015, Landslide mobility and hazards-Implications of the 2014 Oso disaster: Earth and Planetary Science Letters, v. 412, p. 197-208.

Javernick, L., Brasington, J., and Caruso, B., 2014, Modeling the topography of shallow braided rivers using structurefrom-motion photogrammetry: Geomorphology, v. 213, p. 166-182.

Juracek, K.E., and Fitzpatrick, F.A., 2009, Geomorphic applications of stream-streamgage information: River Research and Applications, v. 25, p. 329-347, accessed September 2015, at https://doi.org/10.1002/rra.1163.

Keaton, J.R., Wartman, Joseph, Anderson, Scott, Benoît, Jean, deLaChapelle, John, Gilbert, Robert, and Montgomery, D.R., 2014, The 22 March 2014 Oso Landslide, Snohomish County, Washington, in Geotechnical Extreme Events Reconnaissance (GEER)—Turning Disaster into Knowledge: Sponsored by the National Science Foundation, 172 p. plus appendix.
Keith, M.K., Brown, Jody, and Anderson, S.W., 2017, Surficial sediment data on the North Fork Stillaguamish River and State Route 530 Landslide near Oso, Washington: U.S. Geological Survey data release, https://doi.org/10.5066/ F7VH5M2S.

LaHusen, S.R., Duvall, A.R., Booth, A.M., and Montgomery, D.R., 2016, Surface roughness dating of long-runout landslides near Oso, Washington (USA), reveals persistent postglacial hillslope instability: Geology, v. 44, p. 111-114, accessed September 2016, at https://doi. org/10.1130/G37267.1.

Lane, S.N., Westaway, R.M., and Murray Hicks, D., 2003, Estimation of erosion and deposition volumes in a large, gravel-bed, braided river using synoptic remote sensing: Earth Surface Processes and Landforms, v. 28, no. 3, p. 249-271.

Lisle, T.E., 2007, The evolution of sediment waves influenced by varying transport capacity in heterogeneous rivers: Developments in Earth Surface Processes, v. 11, p. 443-469.

Lorenz, D., Runkel, R., and De Cicco, L., 2015, USGS— rloadest (river load estimation): U.S. Geological Survey software, accessed November 2015, at https://github.com/ USGS-R/rloadest.

Magirl, C.S., Keith, M.K., Anderson, S.W., O’Connor, J.E., Aldrich, Robert, and Mastin, M.C., 2015, Preliminary assessment of aggradation potential in the North Fork Stillaguamish River downstream of the State Route 530 landslide near Oso, Washington: U.S. Geological Survey Scientific Investigations Report 2015-5173, 20 p., accessed January 2015, at http://dx.doi.org/10.3133/sir20155173.

Magirl, C.S., Hilldale, R.C., Curran, C.A., Duda, J.J., Straub, T.D., Domanski, M.M., and Foreman, J.R., 2015, Large-scale dam removal on the Elwha River, Washington, USA—Fluvial sediment load: Geomorphology, v. 246, p. 669-686, accessed January 2015, at https://doi. org/10.1016/j.geomorph.2014.12.032.

Major, J.J., O’Connor, J.E., Podolak, C.J., Keith, M.K., Grant, G.E., Spicer, K.R., Pittman, S., Bragg, H.M., Wallick, J.R., Tanner, D.Q., Rhode, A., and Wilcock, P.R., 2012, Geomorphic response of the Sandy River, Oregon, to removal of Marmot Dam: U.S. Geological Survey Professional Paper 1792, 64 p.

McKay, L., Bondelid, T., Dewald, T., Johnston, J., Moore, R., and Rea, A., 2012, NHDPlus Version 2-User guide: Prepared for the U.S. Environmental Protection Agency by Horizon Systems Corporation and U.S. Geological Survey, accessed November 2015, at http://www.horizon-systems. com/NHDPlus/index.php. 
Nuth, C., and Kääb, A., 2011, Co-registration and bias corrections of satellite elevation data sets for quantifying glacier thickness change: The Cryosphere, v. 5, no. 1, p. 271-290.

O’Connor, J.E., Duda, J.J., and Grant, G.E., 2015, 1000 dams down and counting: Science, v. 348, no. 6234, p. 496-497.

Olsen, D.S., Roper, B.B., Kershner, J.L., Henderson, Richard, and Archer, Eric, 2005, Sources of variability in conducting pebble counts-Their potential influence on the results of stream monitoring programs: Journal of the American Water Resources Association, v. 41, no. 5, p. 1,225-1,236.

Parker, Gary, 1990a, Surface-based bedload transport relation for gravel rivers: Journal of Hydraulic Research, v. 28, no. 4, p. 417-436.

Parker, Gary, 1990b, The ACRONYM series of PSACAL programs for computing bedload transport in gravel rivers: External Memorandum M-220, St. Anthony Falls Laboratory, University of Minnesota, 124 p.

Pitlick, J., 1992, Flow resistance under conditions of intense gravel transport: Water Resources Research, v. 28, p. 891-903.

Pitlick, J., Cui, Y., and Wilcock, P., 2009, Manual for computing bedload transport using BAGS (Bedload Assessment for Gravel-bed Streams) Software: U.S. Forest Service, General Technical Report RMRS-GTR-223, 45 p.

Pourhosein, M., Afzalimehr, H., Singh, V.P., and Dehghani, A.A., 2015, Evaluation of bedload in a gravelbed river: International Journal of Hydraulic Engineering, v. 4, no. 3, p. 70-79.

Randle, T.J., Bountry, J.A., Ritchie, A., and Wille, K., 2015, Large-scale dam removal on the Elwha River, Washington, USA-Erosion of reservoir sediment: Geomorphology, v. 246, p. 709-728.

Rasmussen, P.P., Gray, J.R., Glysson, G.D., and Ziegler, A.C., 2009, Guidelines and procedures for computing timeseries suspended-sediment concentrations and loads from in-stream turbidity-sensor and streamflow data: U.S. Geological Survey Techniques and Methods, book 3, chap. C4, 52 p.

Recking, A., 2013, Simple method for calculating reach-averaged bed-load transport: Journal of Hydraulic Engineering, v. 139, no. 1, p. 70-75.

Riemer, M.F., Collins, B.D., Badger, T.C., Toth, C., and Chun Yu, Y., 2015, Geotechnical soil characterization of intact quaternary deposits forming the March 22, 2014 SR-530 (Oso) Landslide, Snohomish County, Washington: U.S. Geological Survey Open-File Report 2015-1089, 17 p.
Simon, A., and Rinaldi, M., 2006, Disturbance, stream incision, and channel evolution-The roles of excess transport capacity and boundary materials in controlling channel response: Geomorphology, v. 79, no. 3, p. 361-383.

Tullos, D., and Wang, H.W., 2014, Morphological responses and sediment processes following a typhoon-induced dam failure, Dahan River, Taiwan: Earth Surface Processes and Landforms, v. 39, no. 2, p. 245-258.

Turowski, J.M., Rickenmann, D., and Dadson, S.J., 2010, The partitioning of the total sediment load of a river into suspended load and bedload-A review of empirical data: Sedimentology, v. 57, no. 4, p. 1,126-1,146.

U.S. Army Corps of Engineers, 2010, HEC-RAS River Analysis System, applications guide, ver. 4.1: U.S. Army Corps of Engineers, various pagination, available at http:// www.hec.usace.army.mil/software/hec-ras/documentation. aspx.

Wagner, R.J., Boulger, R.W., Jr., Oblinger, C.J., and Smith, B.A., 2006, Guidelines and standard procedures for continuous water-quality monitors-Station operation, record computation, and data reporting: U.S. Geological Survey Techniques and Methods 1-D3, 51 p. +8 attachments, accessed March 19, 2016, http://pubs.water. usgs.gov/tm1d3.

Wallick, J.R., Anderson, S.W., Cannon, Charles, and O'Connor, J.E., 2010, Channel change and bed-material transport in the lower Chetco River, Oregon: U.S. Geological Survey Scientific Investigations Report 20105065, 68 p.

Wartman, J., Montgomery, D.R., Anderson, S.A., Keaton, J.R., Benoît, J., dela Chapelle, J., and Gilbert R., 2016, The 22 March 2014 Oso landslide, Washington, USA: Geomorphology, v. 253, p. 275-288, accessed September 2016, at http://dx.doi.org/10.1016/j. geomorph.2015.10.022.

Westoby, M., Brasington, J., Glasser, N.F., Hambrey, M.J., and Reynolds, J.M., 2012, Structure-from-Motion photogrammetry-A low-cost, effective tool for geoscience applications: Geomorphology v. 179, p. 300-314.

Wilcock, P., Pitlick, J., and Cui, Y., 2009, Sediment transport primer-Estimating bed-material transport in gravel-bed rivers: U.S. Department of Agriculture, Forest Service, Rocky Mountain Research Station, General Technical Report RMRS-GTR-226, 78 p.

Wilcock, P.R., 2001, Toward a practical method for estimating sediment-transport rates in gravel-bed rivers: Earth Surface Processes and Landforms, v. 26, no. 13, p. 1,395-1,408. 
Wilcock, P.R., and Crowe, J.C., 2003, Surface-based transport model for mixed-size sediment: Journal of Hydraulic Engineering, v. 129, p. 120-128.

Wilcox, A.C., O’Connor, J.E., and Major, J.J., 2014, Rapid reservoir erosion, hyperconcentrated flow, and downstream deposition triggered by breaching of $38 \mathrm{~m}$ tall Condit Dam, White Salmon River, Washington: Journal of Geophysical Research, Earth Surface, v. 119, no. 6, p. 1,376-1,394.
Wolman, M.G., 1954, A method of sampling coarse river-bed material: American Geophysical Union Transactions, v. 35, p. 951-956.

Wood, P.J., and Armitage, P.D., 1997, Biological effects of fine sediment in the lotic environment: Environmental management, v. 21, no. 2, p. 203-217. 


\section{Appendix A. Methods}

\section{Repeat Topography Methods}

\section{Structure from Motion: Photograph Acquisition and Processing}

Photographs used for Structure from Motion (SfM) photogrammetry were acquired using a Ricoh GR digital camera, mounted in a near-nadir orientation in the wing of a fixed-wing aircraft. The mount was a custom-modified wing inspection port that allowed the camera to sit fully within the wing, relatively free from wind, and buffered from mechanical vibrations (fig. A1). This design was based on the mount used for monitoring of the Elwha Dam removals (Randle and others, 2015; Andrew Ritchie, U.S. Geological Survey, oral commun., September 30, 2014). Photographs were taken at 1/1000th second exposure times or faster to minimize blur along the direction of motion. The camera was triggered by its own internal intervalometer, set to capture an image every 2 seconds.

Photographs were taken along a grid pattern over the SR 530 Landslide, covering the head scarp to the distal ends of the deposit in the cross-valley direction and from C-Post Bridge to about 1 kilometer $(\mathrm{km})$ downstream of the landslide (roughly river kilometer [rkm] 34.7 to rkm 31). Flight altitude typically was from 300 to 400 meters (m) above ground level (AGL), although several passes over the new channel were made at $200 \mathrm{~m}$ AGL to increase resolution. Each acquisition resulted in about 200-400 photographs of the survey area, and most locations within the survey area were visible in 15-30 photographs. Ground-control points, consisting of white crosses about $1 \times 1 \mathrm{~m}$ in dimension, were laid out in a rough grid over the entire landslide extent. Fourteen ground-control points were laid out, providing a point every 200-300 m. The center point of each " $X$ " was surveyed with Real Time Kinematic-Global Navigation Satellite System (RTK-GNSS), providing locations accurate to about $\pm 0.05 \mathrm{~m}$ in both horizontal and vertical directions. These control points remained in place over the entire study area.

Structure-from-Motion (SfM) processing was done using Agisoft PhotoScan Pro (PhotoScan). Photographs were initially aligned using the high-accuracy setting in the software and generic pair pre-selection. Ground-control points were imported and manually located in the photographs. Obviously spurious match points in the sparse point cloud, with computed positions that sat significantly above, below or outside the survey area, were removed. A bundle adjustment then was completed, optimizing the geometry of camera poses (location and orientation) and the sparse point cloud. In this step, the initially estimated camera calibration model also was improved. Beyond the basic calibration parameters (x and $y$ focal length and $\mathrm{x}$ and $\mathrm{y}$ principal point coordinates), all four radial distortion parameters $(\mathrm{k} 1, \mathrm{k} 2, \mathrm{k} 3$, and $\mathrm{k} 4)$ were fit as well as both decentering distortion parameters (p1 and p2).
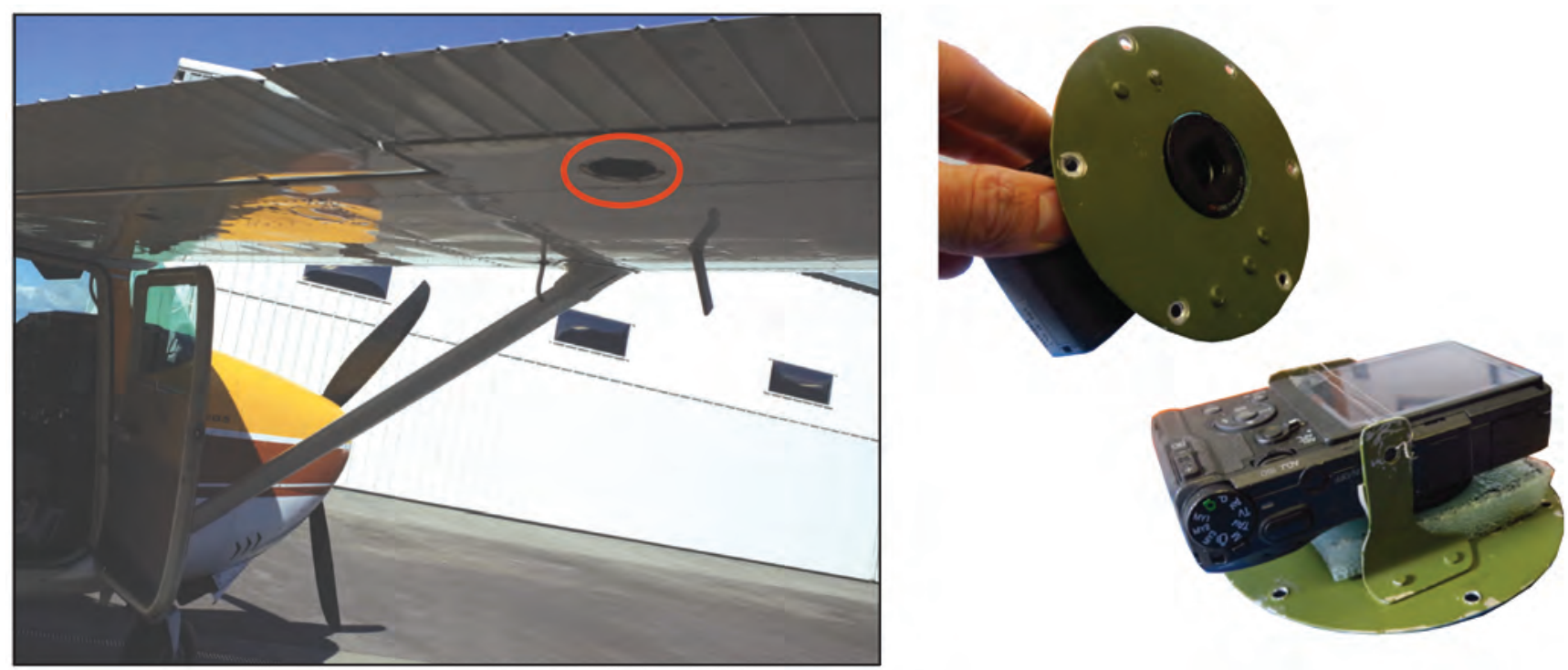

Figure A1. Camera mount used to acquire aerial photographs at the SR 530 Landslide, North Fork Stillaguamish River near Oso, Washington. 
Skew and aspect were not fit because modern digital cameras can be assumed to have zero skew and an aspect ratio of unity (Remondino and Fraser, 2006; Verhoeven and others, 2013). A dense point cloud was generated using the integrated multi-view stereo (MVS) algorithm in PhotoScan, using the high-accuracy setting and aggressive depth filtering. This dense point cloud was then used to create a rasterized digital elevation model (DEM). Raster cell sizes were either 0.5 or $0.25 \mathrm{~m}$ depending on photograph quality (table 1 ). PhotoScan also was used to produce rectified aerial imagery, which the software achieves by projecting the input photographs onto the derived topographic surface. Seven SfM photosets were acquired between November 1, 2014, and July 7, 2015 (table 1). In addition to the seven photosets acquired by the USGS, topography also was generated from the raw aerial photographs acquired on July 1, 2014, by Washington State Department of Transportation (WSDOT). This survey was georeferenced using a sparse ground-control network put in place by WSDOT in combination with visually distinct objects or textures identifiable in the July 1,2014, imagery and in the November 10, 2014, photoset.

\section{Methods for Delineating and Quantifying Geomorphic Change}

In areas that were subaerial in both differenced surveys, such as gravel bars, or where issues of stage variations and submergence were minor relative to the magnitude of observed change, such as along the retreating banks, the area of active change was outlined with polygons and volumetric change was calculated by multiplying measured vertical change by the raster cell area and summed over the delineated areas. Volumetric change within areas that were submerged in both surveys required involved analysis to separate variations in water-surface elevation from true variations in the bed elevation. Both the March 24, 2014, and April 6, 2014, datasets were acquired using aerial lidar, and provide accurate water-surface elevations (although the April 6, 2014, survey included bathymetry of the impoundment lake; that bathymetry did not extend into the actively eroding new channel). Because variations in water-surface elevation related to discharge were small relative to the magnitude of channel incision over this period, change over the wetted channel was considered to predominantly reflect sediment erosion and was summed in the same manner as the banks. This summation was only carried to the position of channelized, energetic flow in the lidar from April 6, 2014, near the eastern edge of the deposit. Upstream of this point, water remained ponded behind the deposit, and observed change predominantly reflected changes in water storage as the outlet channel eroded downward. This precludes any estimate of net erosion through the upstream extents of the deposit, but, given the lack of energetic flow, little erosion likely occurred. Change between April 6 and July 1, 2014, was based on differencing between earlier merged lidar and bathymetric topography and the later SfM topography. Although SfM surveys tended to produce noisy estimates of the water-surface elevation, the July 1, 2014 surface did not have any apparent systematic errors, and the magnitude of the noise (about $0.5 \mathrm{~m}$ ) was small relative to the total erosion within the channel (> $4 \mathrm{~m}$ ). Changes in water storage in the impoundment were not a factor because the April 6 survey included bathymetric data within the impoundment extents, and the impoundment was no longer present by the time of the July 1 survey. This does result in a differencing of the July 1 water-surface with the April 6 channel bed/deposit surface over the upstream-most several hundred meters of channel, which then underestimates the total erosion to a degree equal to the volume of water in the channel in July. This volume was determined to be small relative to the total change and was not corrected for because flows were near lows in July 2014 (fig. 8).

All measured change following July 1, 2014, was based on pairs of SfM-derived topography, and over periods when vertical erosion of the channel bed was small relative to the uncertainty of the water-surface elevations and discharge-related variations. To estimate volumetric change along the wetted channel bed over these periods, the channel was subdivided into orthogonal transects spaced every $20 \mathrm{~m}$ along the channel centerline, creating 20-m long channel segment polygons. The normalized water-surface profiles, which approximately removed discharge-related variations in water-surface elevation, were differenced and the resulting difference assumed to primarily result from changes in bed elevation. The mean vertical change over each channel segment was then multiplied by the area of that segment to estimate the volumetric change. Although this method is approximate, the total volume of material eroded from the bed after July 1, 2014, is a small fraction of the total volume of eroded material.

\section{Error Assessment of Dems}

The inevitable presence of errors in topographic surveys for this study introduces uncertainty into the derived DEMs, which introduces uncertainty into any results based on those DEMs. Several methods were used to assess the likely magnitude of both random error (noise) and systematic errors (bias, or mean error) in the DEMs. First, the absolute accuracy of our SfM-derived topography was assessed by comparison with a 131-point RTK-GNSS survey, conducted coincident with the July 7, 2015, photograph acquisition. Points were taken on bare surfaces well away from vegetation and included points along the steep channel banks, where erosion primarily occurred. Second, comparisons between sequential surveys over areas presumed to be static were used to assess the relative accuracy, or repeatability, of the survey results, a critical measure when the products are used to assess change over time. 
The mean elevation difference between the SfM DEM and RTK-GNSS points was $0.006 \mathrm{~m}$, with a standard deviation (SD) of $0.095 \mathrm{~m}$ (fig. A2). Errors were approximately normally distributed. Error magnitude was weakly correlated with slope; points on slopes less than 10 degrees $(n=89)$ had a SD of $0.08 \mathrm{~m}$, compared with an SD of $0.12 \mathrm{~m}$ for points on slopes greater than 10 degrees $(n=42)$. Doming, a concern when using photographs taken near-parallel to the topography (James and Robson, 2014), was not apparent.

Comparing sequential surveys over areas where true change was expected to be negligible, the mean (systematic) errors ranged from -0.009 to $0.044 \mathrm{~m}$, with an absolute mean of $0.019 \mathrm{~m}$. Standard deviations, representing the magnitude of variability at the level of individual raster cells, ranged from 0.05 to $0.13 \mathrm{~m}$, with a mean of $0.09 \mathrm{~m}$. These values were consistent for both the lidar and SfM data products, and indicated that two survey methods had similar precisions and accuracies.

\section{Volumetric Uncertainty}

Assessing how elevation uncertainties in our DEMs translate into uncertainty in our assessments of net change requires a statistical framework for propagating that uncertainty. The statistical framework developed by Lane and others (2003), which describes the net volumetric error introduced by random errors was used. A term that accounts for uncertainty related to systematic errors, using methods described in East and others (2015) also was included. Because systematic errors and random errors are inherently independent of each other, the uncertainties from these two terms were then combined as the square-root of the sum of squares (referred to as addition in quadrature) to obtain the total uncertainty (Taylor, 1997). For all survey intervals, the standard deviation of random errors was presumed to be $0.15 \mathrm{~m}$, and the likely magnitude of residual systematic errors estimated at $0.05 \mathrm{~m}$. This latter value is a conservative estimate of how much systematic error may be present after having co-registered DEMs.

Estimated volumetric uncertainties ranged from about 1,000 to $6,000 \mathrm{~m}^{3}$, and typically were less than 10 percent of the total volume of change for any given period. The uncertainty around estimates of change over multiple surveys involves both the addition and subtraction of all but the first and last surveys (for example, the change between survey one and survey three is estimated as [(Survey 3 - Survey 2) $+($ Survey $2-$ Survey 1$)]=($ Survey $3-$ Survey 1$)$, and so errors in all but those first and last surveys would cancel out. As a result, uncertainties on the order of $5,000 \mathrm{~m}^{3}$ are also estimated for net change over the two water year periods and the total change over the entire study interval. Over the longer periods, uncertainties are about 1 percent of measured change. These low percentage values indicate that survey uncertainty is not likely to have any substantial effect on the results or interpretations of this study.

Additional uncertainty is introduced when estimates of volumetric change are translated into masses based on bulk densities, and those masses further subdivided into size classes. In the absence of any formal means of assessing uncertainty in the bulk densities, grain-size distributions, or surficial facies mapping, uncertainties for estimates of mass derived from volumetric change are likely on the order of \pm 10 percent of measured values.
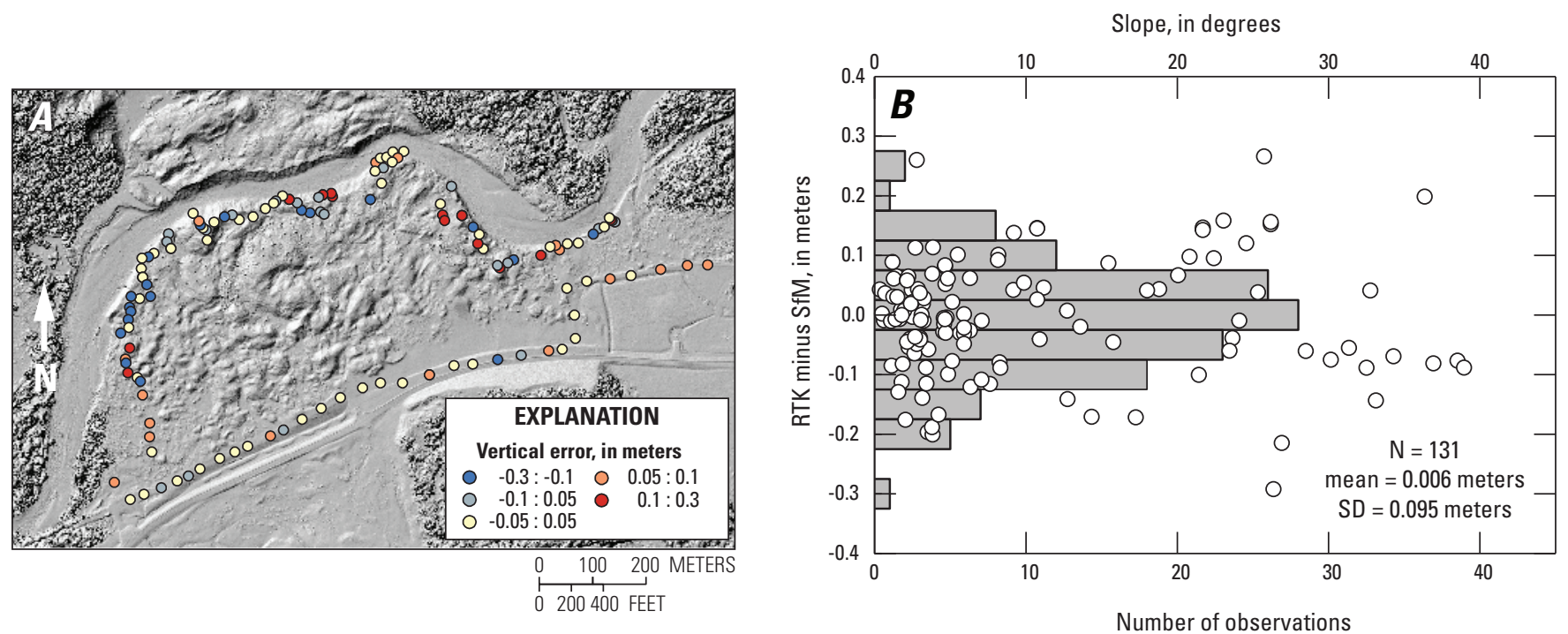

Figure A2. Absolute error assessment for Structure-from-Motion (SfM) topography based on comparison to Real Time KinematicGlobal Navigation Satellite System (RTK-GNSS) survey, North Fork Stillaguamish River, Washington, July 7, 2015. 


\section{Turbidity Sensor Regressions at Whitman}

The three turbidity sensors, referred to here as the Analite, Solitax and DTS-12 in order of installation, operated at North Fork Stillaguamish River near Oso (Whitman) provide, in combination, largely continuous turbidity records for the site with overlap (fig. A3). However, no individual sensor spans the entire study period, and the high number of suspended-sediment concentration (SSC) measurements early in the study, when only one sensor (the Analite) was in operation, leave the other sensors with a limited number of paired samples. For the purpose of computing sediment loads over the entire period of study, the following strategy was used:

The Solitax sensor was selected as the primary sensor recorder. In order to estimate turbidities in the period before the installation of the Solitax (March 24 through April 10, 2014), a regression was created between the Analite and Solitax turbidity records over the period of overlap. This regression was then used to retrodict synthetic Solitax values in late March and early April 2014, based on the existing Analite record.

The Solitax began to experience frequent outages at the start of water year 2015, and the Analite sensor was replaced with a DTS-12 sensor on October 2, 2014. For infilling missing or unreliable Solitax records after October 2, 2014, a regression was created between the Solitax and DTS-12 turbidity records. The details of those regressions are presented herein along with several assessments of the accuracy of sediment loads computed using regression-derived turbidities.

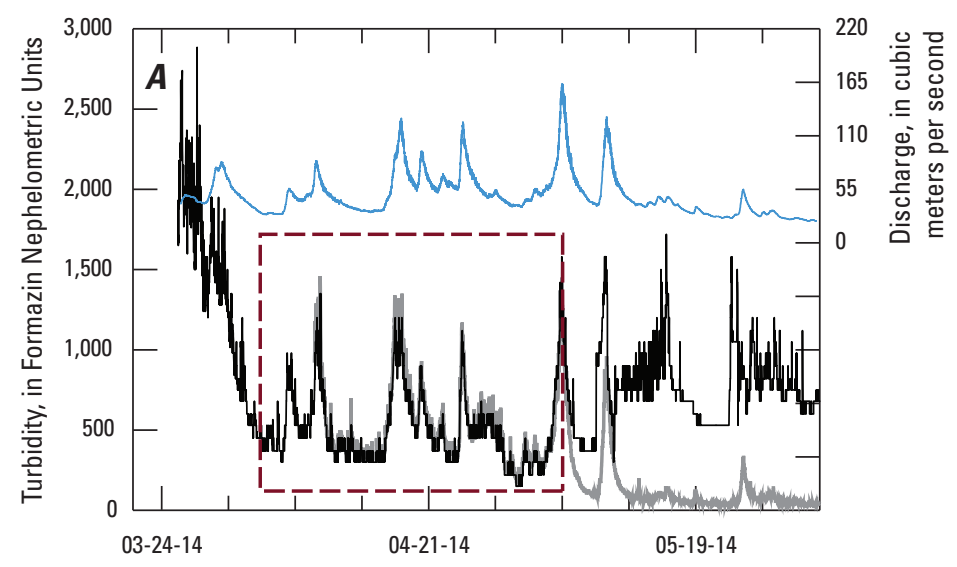

EXPLANATION

- Solitax turbidity

- Analite turbidity

Discharge

- - Period of shared records prior to analite malfunction

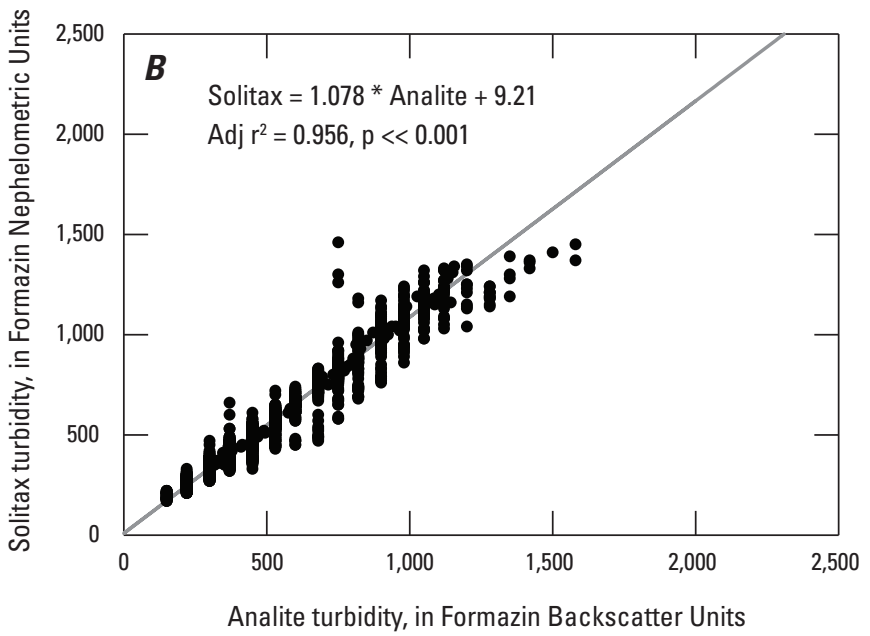

Figure A3. Analite and Solitax sensor turbidity records $(A)$ immediately following the landslide and $(B)$ correlation of the two records with regression line at Whitman, North Fork Stillaguamish River, Washington (USGS streamgage 12166300). 


\section{Analite-Solitax Regression}

The Solitax sensor record began on April 10, 2014, 16 days after the installation of the Analite sensor. Over those 16 days, 13 SSC measurements were made, including all of the highest turbidity measurements. The primary goal of this regression was to retrodict Solitax turbidity values to be paired with those measurements, creating a more complete Solitax rating curve that then could be carried forward through the rest of the study period. The regression was done using concurrent 15-minute turbidity values for the two sensors between April 10, 2014, and May 5, 2014. After May 5, 2014, the Analite sensor record became erratic and decoupled from hydrology, indicating sensor malfunction (fig. A3). This malfunction continued through the end of the deployment of the sensor in October of 2014.

The relation between Analite and Solitax turbidity values were well described by simple linear regression with a slope close to 1 and an intercept of essentially 0 (fig. A3). The relation included data turbidity values as high as 1,500 Formazin Nephelometric Units (FNUs). However, the period of record over which the relation was to be applied included turbidity values as high as 3,000 FNUs. To confirm that the extrapolated turbidity record and the derived rating curve were reasonable, the estimated sediment loads were compared using the combined synthetic and actual Solitax records against those estimated using only the Analite turbidity record and associated rating curve. Over the period from March 26, 2014, the earliest that both turbidity and discharge records were available, through May 5, 2014, when the Analite sensor began to malfunction, the cumulative total loads and fine loads estimated through the two records were essentially identical. The difference between the total loads estimated over the period was 3 percent, whereas the difference in the fine load was 1.5 percent. This level of agreement is somewhat unsurprising because the turbidity-SSC rating curved used for the Solitax and the Solitax turbidity record over the period of highest sediment concentrations are both based on simple linear transformations of the Analite record. Because the two records are not independent, the close agreement indicates that the use of a regression to estimate turbidities and sediment loads before April 10, 2014, did not substantially increase the error, but should not be interpreted as a measure of the total uncertainty in the load estimates.

\section{DRS-12 Solitax Regression}

The DTS-12 sensor record began on October 2, 2014, when it replaced the Analite. The DTS-12 provided a consistent record over most of water year 2015 (WY 2015). However, only three SSC measurements were made in WY 2015, insufficient to make an independent rating curve for the sensor. Instead, the sensor was used to infill or replace missing and malfunctioning periods of the Solitax record, again using sensor regression to create a cross walk between the two sensors.

A plot of concurrent measurements from the Solitax and DTS-12 sensors, after having removed periods of sensor malfunction, indicate two distinct linear relations. One included all data before November 5, 2014, and one included all data after this date (fig. A4). The Solitax sensor probably experienced some amount of bio-fouling or became miscalibrated during summer 2014, resulting in overly low estimates of turbidity at the onset of WY 2015. The use of these turbidity values to estimate SSC then would result in an underestimate of the true suspended sediment load. The condition was rectified during a site visit on November 5 , 2014, and the sensor record after this date was assumed to have the same relation with SSC observed in the WY 2014-LS period of record. The regression from the period after November 5, 2014, was used to estimate all Solitax values from October 2 to November 5, 2014, and to fill in gaps in the Solitax record from November 5, 2014, through September 30, 2015. This ensured that a consistent relation between turbidity and SSC was used over the entire period of record.

Using only the timestamps for creating the initial regression, the difference in total load estimated using the native Solitax turbidity values and those estimated using the DTS- 12 regressed values was 0.5 percent. After this analysis had been completed, additional records (between August 29 and September 30, 2015) became available. These records were not used in the initial regression, and they included several modest turbidity spikes. Over this latter period of record, the difference between the native Solitax estimates of suspended-sediment load (SSL) and those based on the DTS-12 regression differed by about 3 percent. The small size of these discrepancies confirms that the relation between the two turbidity sensor records was well defined and stable over the period of analysis. 


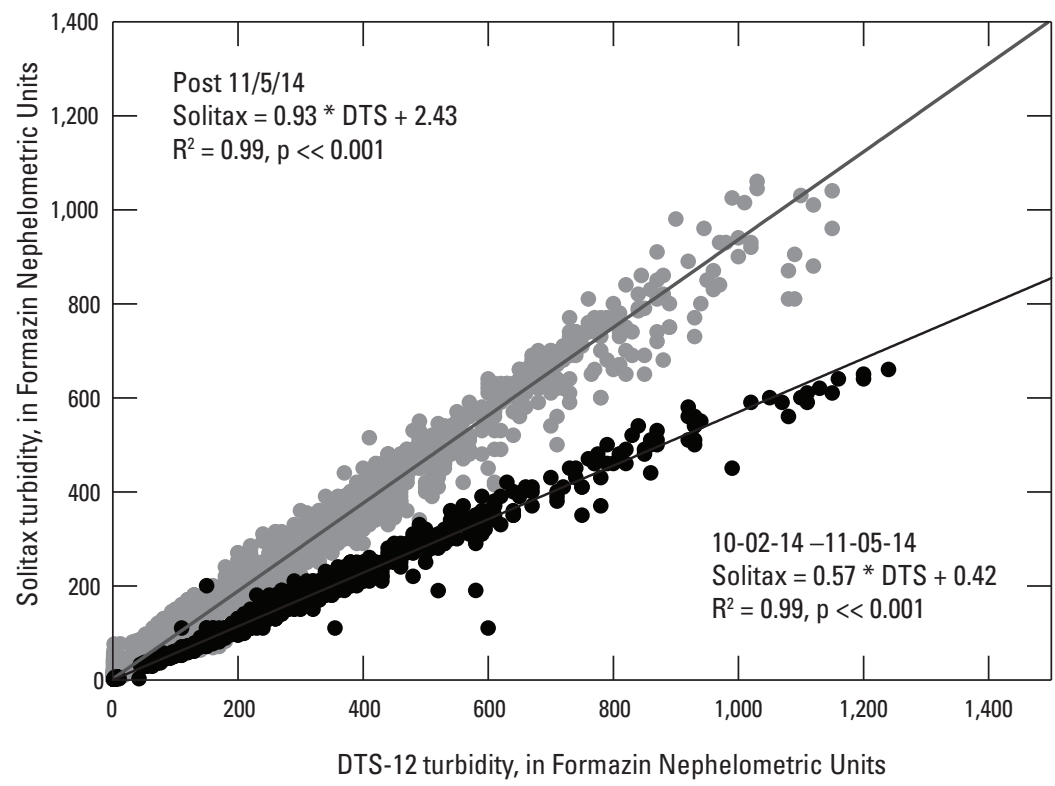

EXPLANATION

- 10-02-14-11-05-14

- Post 11-05-14

Figure A4. Solitax and DTS-12 sensor turbidity regression, showing two distinct relations before and after November 5, 2014. The difference in regressions probably is a result of biofouling of the Solitax sensor, which resulted in overly low turbidity readings until rectified November 5, 2014.

\section{Assessment of Accuracy Based on Independent Measurements and Sensor Records}

The timing of SSC measurements and sensor records at Whitman provide one instance in which two totally independent estimates of SSL could be computed, allowing an empirical assessment of the accuracy of turbidity as a surrogate for SSL. Between April 10 and May 5, 2014, both the Analite and Solitax sensors were operational and provided independent estimates of turbidity. Those estimates of turbidity were then translated into SSC, and then into SSL, using two independent sets of SSC measurements. The rating curve for the Solitax sensor was constructed using the five measurements taken between April 10 and May 5, 2014, using a simple linear regression (fig. A5). The rating curve for the Analite sensor was constructed using only measurements obtained before April 10, 2014.

During the overlapping period of record, the two turbidity records estimate nearly identical estimates of SSC, and the cumulative sediment load estimated from the two sensors agreed within 2 percent. These results indicate that estimates of suspended-sediment load are highly repeatable, and increase confidence that the results are accurate. 

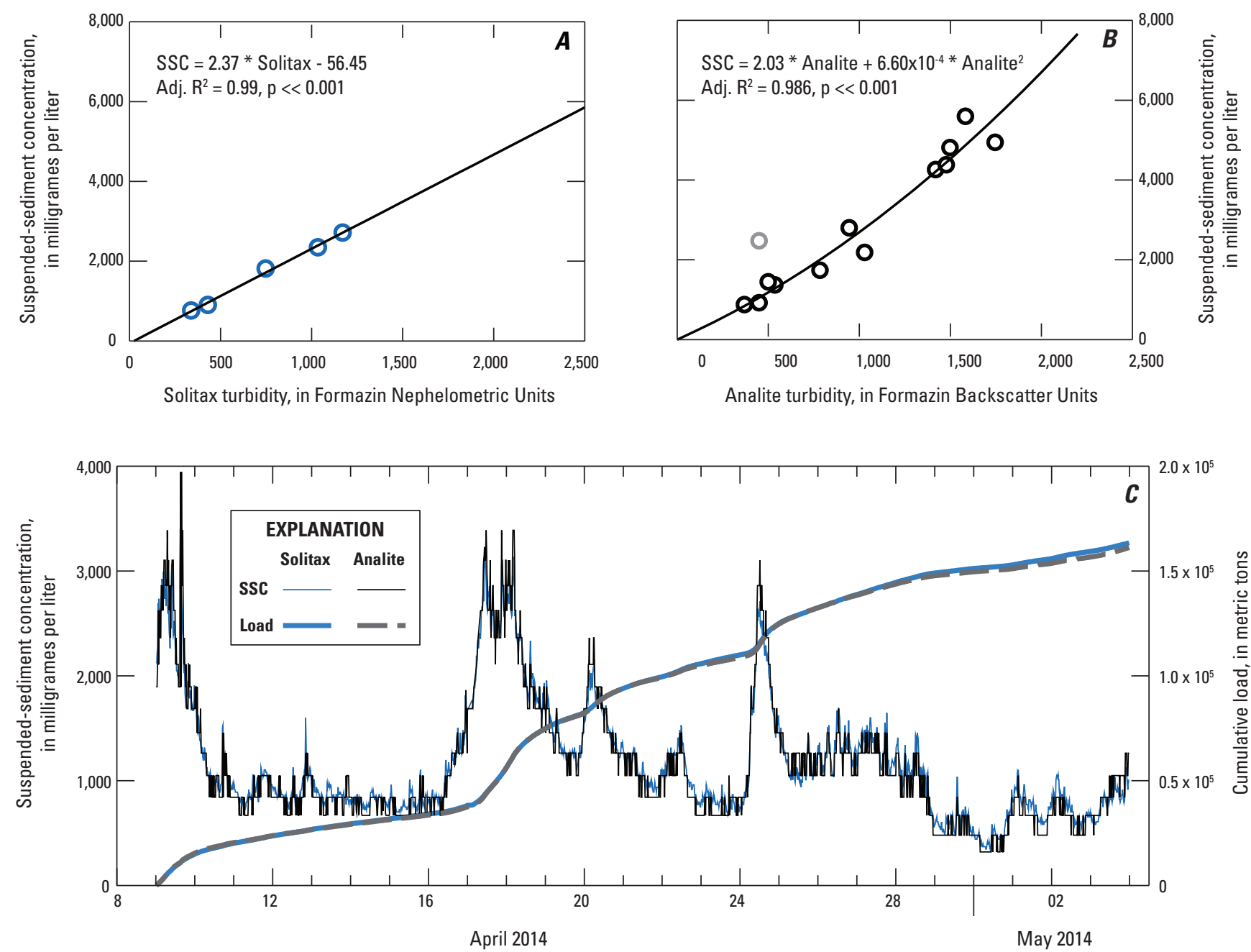

Figure A5. Comparison of suspended-sediment concentration (SSC) and suspended-sediment load estimates using independent sensor records, and calibrated using non-overlapping SSC samples. (A) Regression between Solitax sensor turbidity and measured SSC. (B) Regression between Analite sensor turbidity and measured SSC, omitting samples used in Solitax regression. $(C)$ Comparison of estimated SSC and cumulative loads from the two independent sensors and regressions. 


\section{Sediment Transport Modeling}

\section{HEC-RAS Model Validation}

The Hydraulic Engineering Center-River Analysis System (HEC-RAS) one-dimensional hydraulic model used in the transport modeling simulations was validated by Snohomish County on the basis of high water marks from the storm on December 10, 2010. Additional validation of the model was done using the measured stage-discharge relations at USGS streamgages near Arlington (Arlington) and the low-flow water surface in the April 2014 lidar. Cross-section 20883 was approximately $50 \mathrm{~m}$ downstream of the Arlington streamgage. The April 2014 lidar provided low-flow watersurface elevations for the entire North Fork Stillaguamish River Basin. The survey continued over the span of several days when the discharge at Arlington ranged from about 50 to 100 cubic meters per second $\left(\mathrm{m}^{3} / \mathrm{s}\right)$. HEC-RAS-estimated water-surface elevations were generated for these two bounding discharges and compared to measured water surface elevations from the lidar. At the Arlington streamgage, simulated stages are most commonly about $0.1 \mathrm{~m}$ above the rating curve, although over and under estimates of about $0.3 \mathrm{~m}$ occurred for low flows (table A1).

The simulated water-surface elevations for flows ranging from 52 to $101 \mathrm{~m}^{3} / \mathrm{s}$ generally approximated the observed elevations in the 2014 lidar (fig. A6). Excluding cross sections that were not derived from the 2014 lidar (within the SR 530 Landslide extents of rkm 35.7-32.6 and upstream of rkm 43.4), the lidar water-surface elevation was within the simulated range at 60 percent of the cross sections, and was within $0.2 \mathrm{~m}$ of the simulated range at 90 percent of the cross sections. There were no obvious systematic errors; overestimates were as likely as underestimates. These model simulation results were considered sufficiently accurate for the high-level assessments of sediment transport trends for the study area. However, this model was not intended for and should not be used for any type of flood inundation assessment.

Table A1. Comparison of simulated water-surface elevations from Hydraulic Engineering Center-River Analysis System (HECRAS) model output flows at North Fork Stillaguamish River near Arlington, Washington (USGS streamgage 12167000).

[Values are in meters. Rating curve 27 is a gage-specific rating identifier valid for a specific period (current from July 2014 through December 2016). Abbreviations AEP, annual exceedance probability; $\mathrm{m}^{3} / \mathrm{s}$, cubic meter per second; USGS, U.S. Geological Survey; 1-D, one-dimensional]

\begin{tabular}{|c|c|c|c|c|c|c|c|c|}
\hline & $\begin{array}{c}0.125 * 0.50 \\
\text { AEP } \\
85 \mathrm{~m}^{3} / \mathrm{s}\end{array}$ & $\begin{array}{c}0.25 * 0.50 \\
\text { AEP } \\
170 \mathrm{~m}^{3} / \mathrm{s}\end{array}$ & $\begin{array}{c}0.5 * 0.50 \\
\text { AEP } \\
340 \mathrm{~m}^{3} / \mathrm{s}\end{array}$ & $\begin{array}{c}0.50 \\
\text { AEP } \\
680 \mathrm{~m}^{3} / \mathrm{s}\end{array}$ & $\begin{array}{c}0.10 \\
\text { AEP } \\
968 \mathrm{~m}^{3} / \mathrm{s}\end{array}$ & $\begin{array}{c}0.04 \\
\text { AEP } \\
1,160 \mathrm{~m}^{3} / \mathrm{s}\end{array}$ & $\begin{array}{c}0.02 \\
\text { AEP } \\
1,260 \mathrm{~m}^{3} / \mathrm{s}\end{array}$ & $\begin{array}{c}0.01 \\
\text { AEP } \\
1,350 \mathrm{~m}^{3} / \mathrm{s}\end{array}$ \\
\hline 1-D flow model & 29.52 & 30.31 & 31.41 & 32.36 & 32.72 & 32.90 & 32.97 & 33.04 \\
\hline Rating curve 27 & 29.77 & 30.26 & 31.07 & 32.16 & 32.64 & 32.83 & 32.89 & 32.94 \\
\hline Difference & -0.25 & 0.05 & 0.34 & 0.20 & 0.08 & 0.07 & 0.08 & 0.10 \\
\hline
\end{tabular}




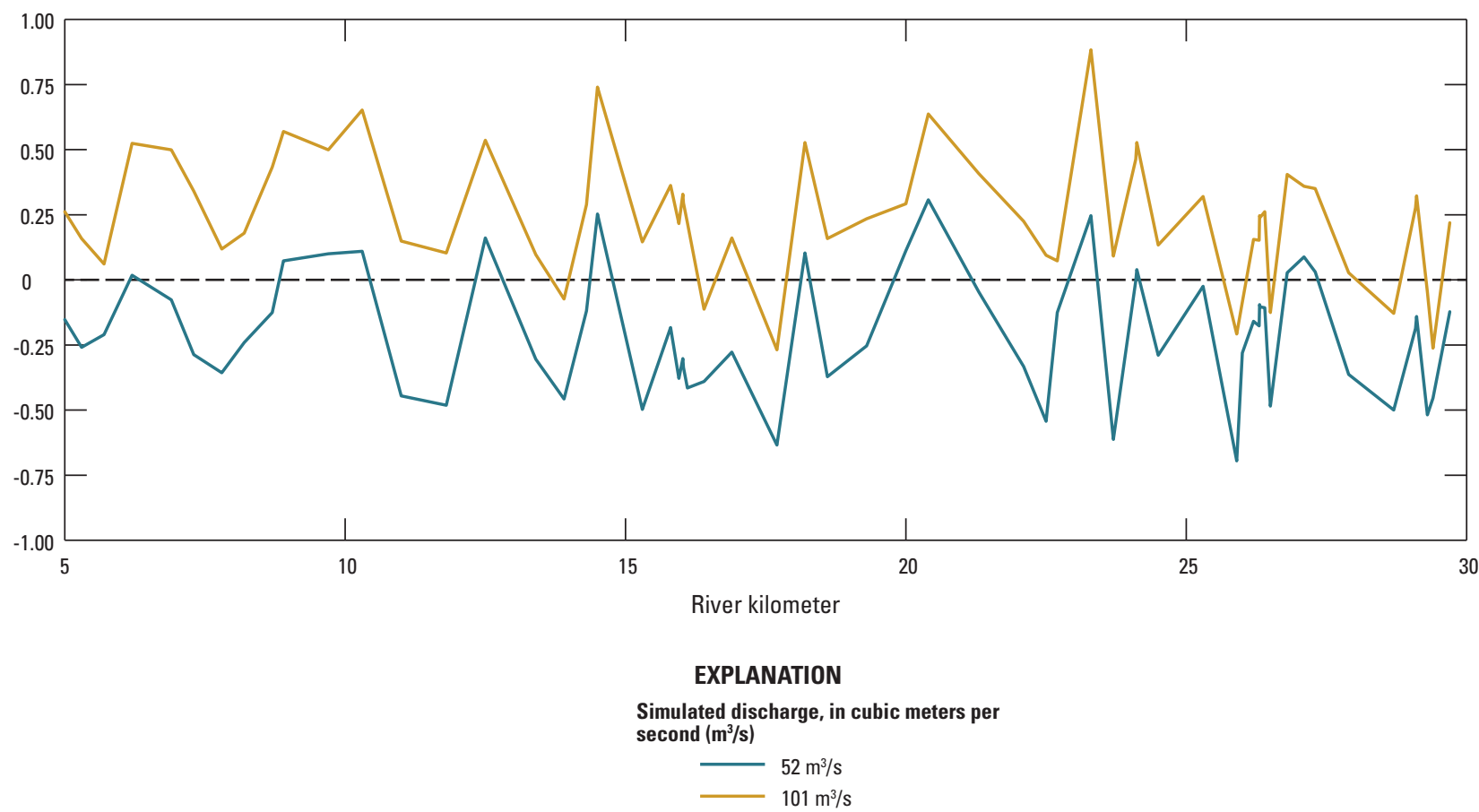

Figure A6. Comparison of simulated and 2014 aerial light detection and ranging (lidar) water-surface elevations at North Fork Stillaguamish River at Arlington, Washington (USGS streamgage 12167000). The two simulated discharges represent the upper and lower discharges measured at the Arlington streamgage over the days when 2014 lidar data were collected. Data are presented as the difference between the simulated and measured water-surface elevation.

\section{Comparison of Measured and Calculated Bedload Transport Rates}

The measured bedload transport rates at Whitman Road Bridge provide a means of validating the various transport equations. The measured transport rates were compared to both the estimates from cross section directly at the bridge, as well as against a reach-median rating curve. The reach median rating curve was constructed by selecting the median transport rate for a given flow scenario from the population of cross sections in the Whitman Reach, and is considered representative of the reach-scale conditions in the study area.

Directly at the bridge, the estimates of the Wilcock and Crowe (2003) and hydraulic radius form of the Recking equation bracketed the measured bedload transport rates (fig. A7). The Parker (1990a, 1990b) equation had the steepest slope in log-log space, and underestimated measured transport rates at low flows but was reasonably close to the only highflow measurement. The discharge form of the Recking (2013) equation underestimated transport at all discharges. When the estimates were aggregated over the entire Whitman reach, the estimates of the Wilcock and Crowe (2003) equations provided the best agreement to the measured data. All other equations underestimated transport, often by an order of magnitude. Based on these observations, the Wilcock and Crowe (2003) equation was determined to provide the most reasonable estimate of the reach-scale transport conditions for the SR 530 Landslide study area.

The relative success of the Wilcock and Crowe (2003) equation likely can be linked to the explicit treatment of sand transport. In contrast, the Parker (1990a, 1990b) equation provides only transport estimates for size classes coarser the $2 \mathrm{~mm}$, and the Recking (2013) equation was formulated more as an estimate of gravel transport and uses only the median and 84th percentile of the surficial grain-size distribution in estimating loads. Because sand comprised a large fraction of the sediment input from the landslide and between 20 and 60 percent of the material in the bedload samples collected, there is a clear physical reason to prefer an equation that simulates sand transport. However, the Parker (1990a, 1990b) and Recking (2013) equations still provided reasonable estimates of the spatial trends in transport capacity and were used to determine the spatial coherence of observed trends. 

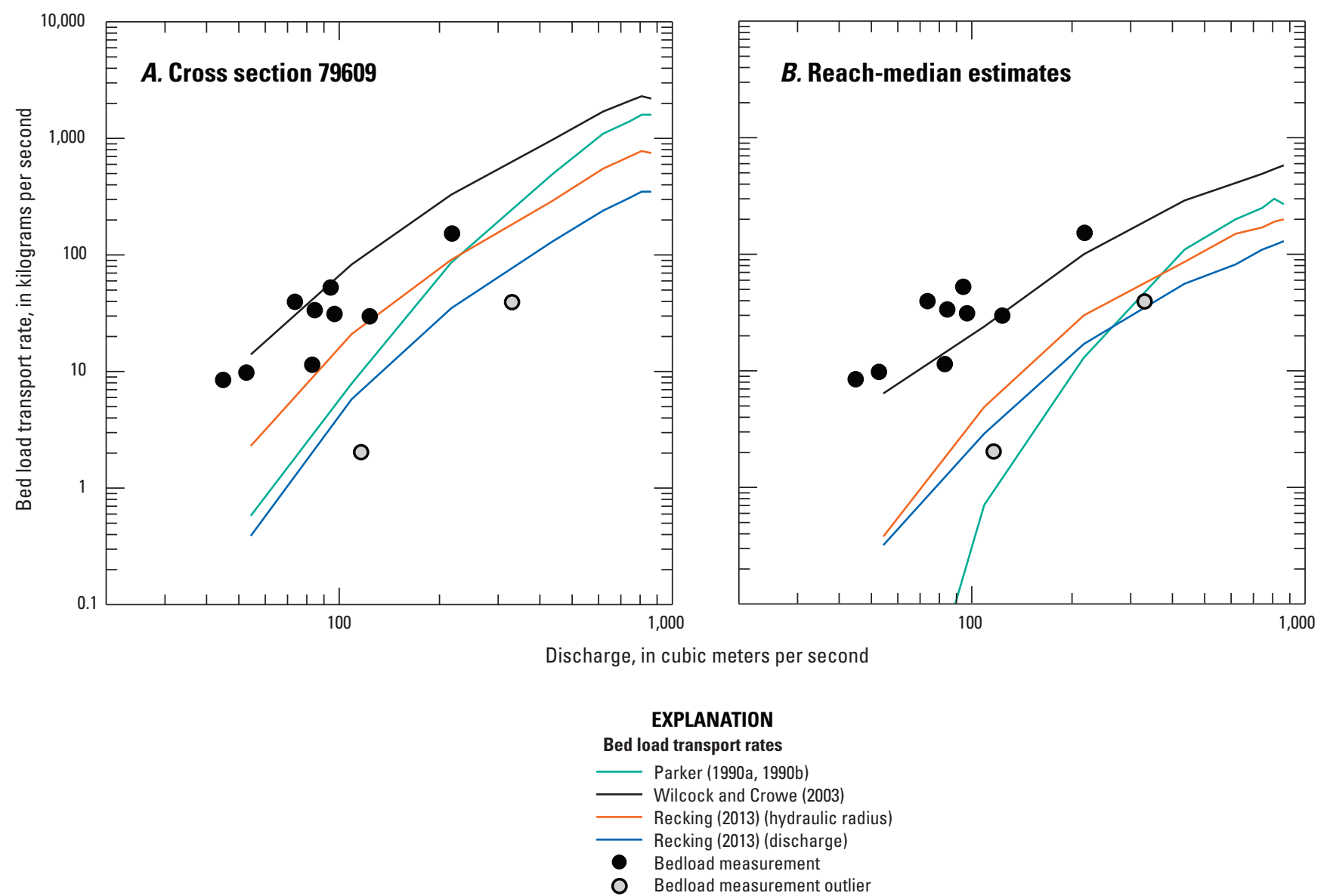

Figure A7. Comparison of estimated bedload transport capacities from transport equations and measured transport rates based on bedload sampling at Whitman Road Bridge, North Fork Stillaguamish River near Oso, Washington. (A) Transport equations from cross section directly co-located with the bedload sampling site. (B) Reach median transport estimates using the median transport over all cross sections in the Whitman Reach to construct an average bedload rating curve. 


\section{References Cited}

East, A.E., Pess, G.R., Bountry, J.A., Magirl, C.S., Ritchie, A.C., Logan, J.B., Randle, T.J., Mastin, M.C., Minear, J.T., Duda, J.J., and Liermann, M.C., 2015, Large-scale dam removal on the Elwha River, Washington, USA - River channel and floodplain geomorphic change: Geomorphology, v. 228, p. 765-786.

James, M.R., and Robson, S., 2014, Mitigating systematic error in topographic models derived from UAV and ground-based image networks: Earth Surface Processes and Landforms, v. 39, p. 1,413-1,420, accessed October 2015 at http://dx.doi.org/10.1002/esp.3609.

Lane, S.N., Westaway, R.M., and Murray Hicks, D., 2003, Estimation of erosion and deposition volumes in a large, gravel-bed, braided river using synoptic remote sensing: Earth Surface Processes and Landforms, v. 28, no. 3, p. 249-271.

Parker, Gary, 1990a, Surface-based bedload transport relation for gravel rivers: Journal of Hydraulic Research, v. 28, no. 4, p. 417-436.

Parker, Gary, 1990b, The ACRONYM series of PSACAL programs for computing bedload transport in gravel rivers: External Memorandum M-220, St. Anthony Falls Laboratory, University of Minnesota, 124 p.
Randle, T.J., Bountry, J.A., Ritchie, A., and Wille, K., 2015, Large-scale dam removal on the Elwha River, Washington, USA-Erosion of reservoir sediment: Geomorphology, v. 246, p. 709-728.

Recking, A., 2013, Simple method for calculating reachaveraged bed-load transport: Journal of Hydraulic Engineering, v. 139, no. 1, p. 70-75.

Remondino, F., and Fraser, C., 2006, Digital camera calibration methods-Considerations and comparisons: International Archives of Photogrammetry, Remote Sensing and Spatial Information Sciences, v. 36, no. 5, 266-272.

Taylor, J., 1997, Introduction to error analysis - The study of uncertainties in physical measurements, vol. 1: New York, University Science Books, 327 p.

Verhoeven, G., Sevara, C., Karel, W., Ressl, C., Doneus, M., and Briese, C., 2013, Undistorting the past-New techniques for orthorectification of archaeological aerial frame imagery, in Cosrsi, C., ed., Good practice in archaeological diagnostics: Switzerland, Springer International Publishing, p. 3-67.

Wilcock, P.R., and Crowe, J.C., 2003, Surface-based transport model for mixed-size sediment: Journal of Hydraulic Engineering, v. 129, p. 120-128. 

Publishing support provided by the U.S. Geological Survey

Science Publishing Network, Tacoma Publishing Service Center

For more information concerning the research in this report, contact the Director, Washington Water Science Center

U.S. Geological Survey

934 Broadway, Suite 300

Tacoma, Washington 98402

https://wa.water.usgs.gov 
